\title{
Quantities and Characteristics of the Contact-Handled Low-Level Mixed Waste Streams for the DOE Complex
}

T. L. Huebner

J. M. Wilson

A. H. Ruhter

S. J. Bonney

SAIC Waste Management Technology Division

545 Shoup Avenue

Idaho Falls, ID 83402

Published August 1994

Idaho National Engineering Laboratory

EG\&G Idaho, Inc.

Idaho Falls, Idaho 83415

Prepared for the

U.S. Department of Energy

Assistant Secretary for Environmental Management

Under DOE Idaho Operations Office

Contract DE-AC07-76ID01570 


\section{DISCLAIMER}

This report was prepared as an account of work sponsored by an agency of the United States Government. Neither the United States Government nor any agency thereof, nor any of their employees, make any warranty, express or implied, or assumes any legal liability or responsibility for the accuracy, completeness, or usefulness of any information, apparatus, product, or process disclosed, or represents that its use would not infringe privately owned rights. Reference herein to any specific commercial product, process, or service by trade name, trademark, manufacturer, or otherwise does not necessarily constitute or imply its endorsement, recommendation, or favoring by the United States Government or any agency thereof. The views and opinions of authors expressed herein do not necessarily state or reflect those of the United States Government or any agency thereof. 


\section{DISCLAIMER}

Portions of this document may be illegible in electronic image products. Images are produced from the best available original document. 


\title{
Quantities and Characteristics of the Contact-Handled Low-Level Mixed Waste Streams for the DOE Complex
}

\author{
EGG-MS-11303
}

Prepared By:

Jang of. Decelones

T. L. Huebner, Program Engineer

SAIC

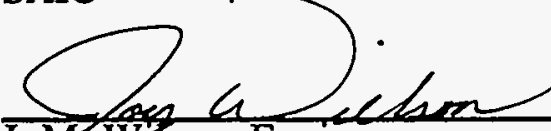

J. I1. Wison, Engineer

SAIC

Reviewed By:

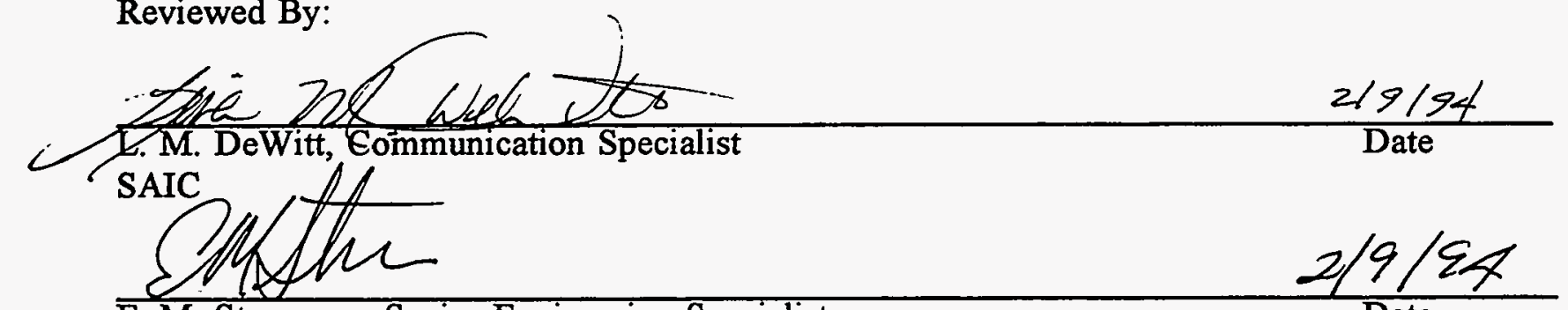

E. M. Steverson, Senior Engineering Specialist

Date

SAIC

Reviewed and Approved by:

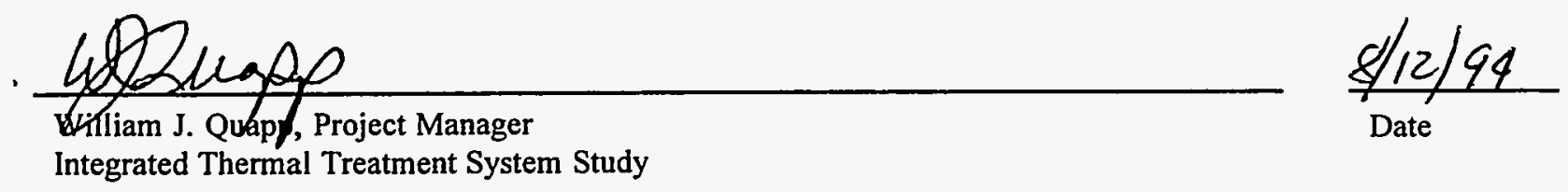




\begin{abstract}
This report supports the Integrated Thermal Treatment System (ITTS) Study initiated by the Department of Energy (DOE) Office of Technology Development (EM-50), which is a system engineering assessment of a variety of mixed waste treatment processes. The DOE generates and stores large quantities of mixed wastes that are contaminated with both chemically hazardous and radioactive species. The treatment of these mixed wastes requires meeting the standards established by the Environmental Protection Agency for the specific hazardous contaminants regulated under the Resource Conservation and Recovery Act while also providing adequate control of the radionuclides.

The thrust of the study is to develop preconceptual designs and life-cycle cost estimates for integrated thermal treatment systems ranging from conventional incinerators, such as rotary kiln and controlled air systems, to more innovative but not yet established technologies, such as molten salt and molten metal waste destruction systems. Prior to this engineering activity, the physical and chemical characteristics of the DOE low-level mixed waste streams to be treated must be defined or estimated. This report describes efforts to estimate the DOE waste stream characteristics.
\end{abstract}




\section{CONTENTS}

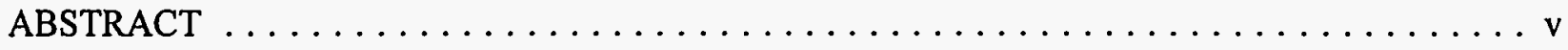

ACRONYMS AND ABBREVIATIONS $\ldots \ldots \ldots \ldots \ldots \ldots \ldots \ldots \ldots \ldots \ldots \ldots \ldots \ldots$ xiii

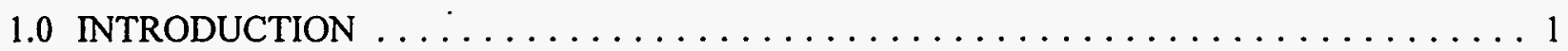

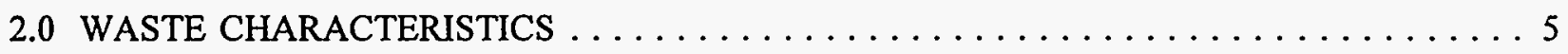

2.1 Container Selection $\ldots \ldots \ldots \ldots \ldots \ldots \ldots \ldots \ldots \ldots \ldots \ldots \ldots \ldots \ldots \ldots \ldots \ldots \ldots \ldots \ldots$

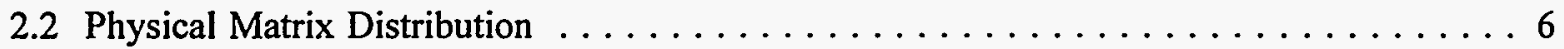

2.3 Elemental Composition ............................ 7

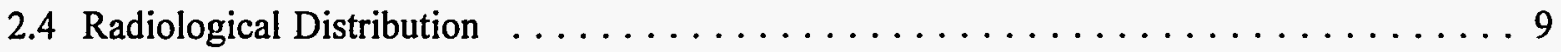

2.5 Heating Value Calculations $\ldots \ldots \ldots \ldots \ldots \ldots \ldots \ldots \ldots \ldots \ldots \ldots \ldots \ldots \ldots \ldots \ldots \ldots \ldots$

2.6 Density Calculations . . . . . . . . . . . . . . . . . . . 10

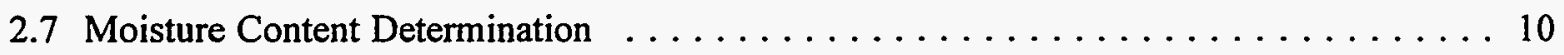

2.8 Combustible Matter Determination $\ldots \ldots \ldots \ldots \ldots \ldots \ldots \ldots \ldots \ldots \ldots \ldots \ldots \ldots \ldots \ldots \ldots \ldots \ldots$

2.9 Acid Gas Precursor Calculations $\ldots \ldots \ldots \ldots \ldots \ldots \ldots \ldots \ldots \ldots \ldots \ldots \ldots \ldots \ldots$

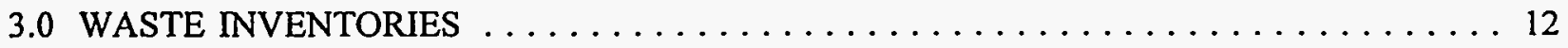

3.1 Argonne National Laboratory--East $\ldots \ldots \ldots \ldots \ldots \ldots \ldots \ldots \ldots \ldots \ldots \ldots \ldots \ldots \ldots \ldots$

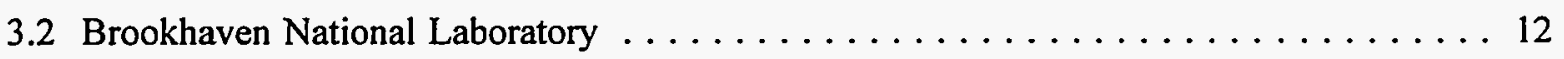

3.3 Energy Technology Engineering Center $\ldots \ldots \ldots \ldots \ldots \ldots \ldots \ldots \ldots \ldots \ldots \ldots \ldots \ldots \ldots \ldots \ldots$

3.4 Fernald Environmental Management Project $\ldots \ldots \ldots \ldots \ldots \ldots \ldots \ldots \ldots \ldots \ldots \ldots \ldots \ldots$

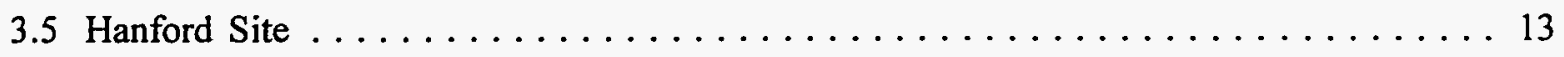

3.6 Idaho National Engineering Laboratory $\ldots \ldots \ldots \ldots \ldots \ldots \ldots \ldots \ldots \ldots \ldots$

3.7 Lawrence Livermore National Laboratory $\ldots \ldots \ldots \ldots \ldots \ldots \ldots \ldots \ldots \ldots$

3.8 Los Alamos National Laboratory . . . . . . . . . . . . . . . . . . 14

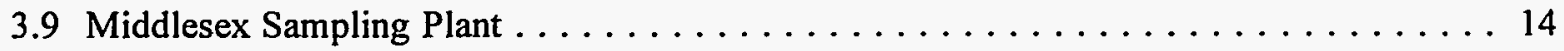

3.10 Oak Ridge National Laboratory $\ldots \ldots \ldots \ldots \ldots \ldots \ldots \ldots \ldots \ldots \ldots \ldots \ldots \ldots \ldots$

3.11 Oak Ridge National Laboratory, K-25 Site $\ldots \ldots \ldots \ldots \ldots \ldots \ldots \ldots \ldots \ldots \ldots \ldots \ldots \ldots$

3.12 Oak Ridge National Laboratory, Y-12 Plant $\ldots \ldots \ldots \ldots \ldots \ldots \ldots \ldots \ldots \ldots \ldots \ldots \ldots$

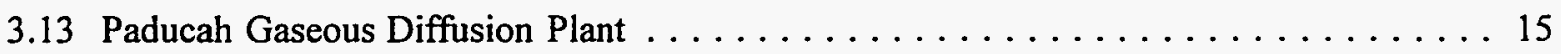




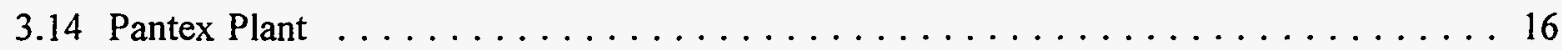

3.15 Portsmouth Gaseous Diffusion Plant $\ldots \ldots \ldots \ldots \ldots \ldots \ldots \ldots \ldots \ldots \ldots \ldots \ldots$

3.16 Puget Sound Naval Shipyard $\ldots \ldots \ldots \ldots \ldots \ldots \ldots \ldots \ldots \ldots \ldots \ldots \ldots \ldots \ldots \ldots$

3.17 Rocky Flats Plant $\ldots \ldots \ldots \ldots \ldots \ldots \ldots \ldots \ldots \ldots \ldots \ldots \ldots \ldots$

3.18 Sandia National Laboratory $\ldots \ldots \ldots \ldots \ldots \ldots \ldots \ldots \ldots \ldots \ldots \ldots \ldots$

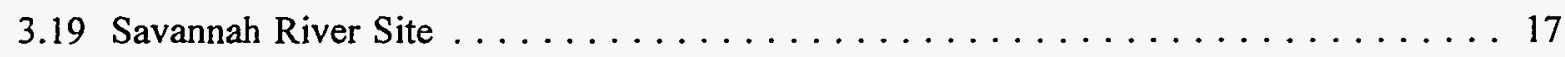

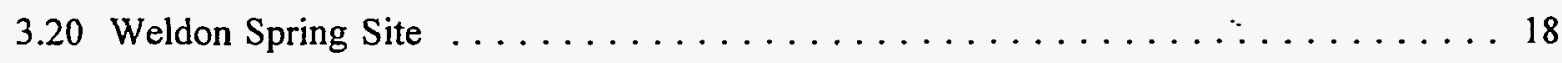

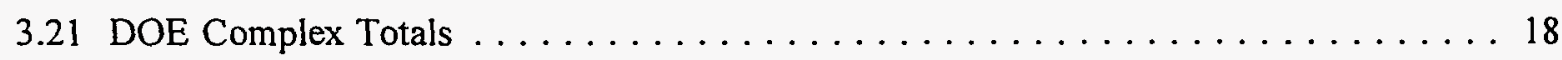

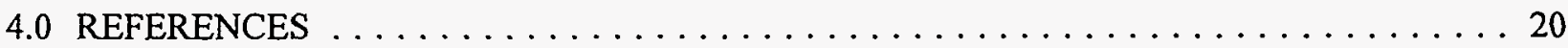

Figures

All figures are located at the end of the report.

Figure 3.1. Physical Matrix Distribution for the DOE Complex

Figure 3.2. Physical Matrix Distribution for the DOE Complex

Figure 3.3. Waste Distribution for the DOE Complex Including Containers

Figure 3.4. Waste Distribution for the DOE Complex Excluding Containers

Figure 3.5. Combustible vs. Noncombustible for DOE Complex Including Containers

Figure 3.6. Combustible vs. Noncombustible for DOE Complex Excluding Containers

Figure 3.7. Combustible Physical Matrix Distribution for the DOE Complex

Figure 3.8. Noncombustible Physical Matrix Distribution for the DOE Complex

Figure 3.9. Physical Matrix Distribution for Argonne National Laboratory--East

Figure 3.10. Combustible vs Noncombustible for Argonne National Laboratory--East

Figure 3.11. Combustible Physical Matrix Distribution for Argonne National Laboratory--East

Figure 3.12. Noncombustible Physical Matrix Distribution for Argonne National Laboratory-East

Figure 3.13. Radiological Distribution for Argonne National Laboratory--East

Figure 3.14. Physical Matrix Distribution for Brookhaven National Laboratory

Figure 3.15. Combustible vs Noncombustible for Brookhaven National Laboratory

Figure 3.16. Combustible Physical Matrix Distribution for Brookhaven National Laboratory

Figure 3.17. Noncombustible Physical Matrix Distribution for Brookhaven National Laboratory

Figure 3.18. Radiological Distribution for Brookhaven National Laboratory 
Figure 3.19. Physical Matrix Distribution for Energy Technology Engineering Center

Figure 3.20. Combustible vs Noncombustible for Energy Technology Engineering Center

Figure 3.21. Noncombustible Physical Matrix Distribution for Energy Technology Engineering Center

Figure 3.22. Radionuclide Distribution for Energy Technology Engineering Center

Figure 3.23. Physical Matrix Distribution for Fernald Environmental Management Project

Figure 3.24. Combustible vs Noncombustible for Fernald Environmental Management Project

Figure 3.25. Combustible Physical Matrix Distribution for Fernald Environmental Management

Project

Figure 3.26. Noncombustible Physical Matrix Distribution for Fernald Environmental Management Project

Figure 3.27. Radiological Distribution for Fernald Environmental Management Project

Figure 3.28. Physical Matrix Distribution for Hanford Site

Figure 3.29. Combustible vs Noncombustible for Hanford Site

Figure 3.30. Combustible Physical Matrix Distribution for Hanford Site

Figure 3.31. Noncombustible Physical Matrix Distribution for Hanford Site

Figure 3.32. Radiological Distribution for Hanford Site

Figure 3.33. Physical Matrix Distribution for Idaho National Engineering Laboratory

Figure 3.34. Combustible vs Noncombustible for Idaho National Engineering Laboratory

Figure 3.35. Combustible Physical Matrix Distribution for Idaho National Engineering Laboratory

Figure 3.36. Noncombustible Physical Matrix Distribution for Idaho National Engineering Laboratory

Figure 3.37. Radiological Distribution for Idaho National Engineering Laboratory

Figure 3.38. Physical Matrix Distribution for Lawrence Livermore National Laboratory

Figure 3.39. Combustible vs Noncombustible for Lawrence Livermore National Laboratory

Figure 3.40. Combustible Physical Matrix Distribution for Lawrence Livermore National Laboratory

Figure 3.41. Noncombustible Physical Matrix Distribution for Lawrence Livermore National Laboratory

Figure 3.42. Radiological Distribution for Lawrence Livermore National Laboratory

Figure 3.43. Physical Matrix Distribution for Los Alamos National Laboratory

Figure 3.44. Combustible vs Noncombustible for Los Alamos National Laboratory

Figure 3.45. Combustible Physical Matrix Distribution for Los Alamos National Laboratory

Figure 3.46. Noncombustible Physical Matrix Distribution for Los Alamos National Laboratory 
Figure 3.47. Radiological Distribution for Los Alamos National Laboratory

Figure 3.48. Physical Matrix Distribution for Middlesex Sampling Plant

Figure 3.49. Combustible vs Noncombustible for Middlesex Sampling Plant

Figure 3.50. Combustible Physical Matrix Distribution for Middlesex Sampling Plant

Figure 3.51. Noncombustible Physical Matrix Distribution for Middlesex Sampling Plant

Figure 3.52. Radiological Distribution for Middlesex Sampling Plant

Figure 3.53. Physical Matrix Distribution for Oak Ridge National Laboratory ‘

Figure 3.54. Combustible vs Noncombustible for Oak Ridge National Laboratory

Figure 3.55. Combustible Physical Matrix Distribution for Oak Ridge National Laboratory

Figure 3.56. Noncombustible Physical Matrix Distribution for Oak Ridge National Laboratory

Figure 3.57. Radiological Distribution for Oak Ridge National Laboratory

Figure 3.58. Physical Matrix Distribution for Oak Ridge National Laboratory, K-25 Site

Figure 3.59. Combustible vs Noncombustible for Oak Ridge National Laboratory, K-25 Site

Figure 3.60. Combustible Physical Matrix Distribution for Oak Ridge National Laboratory, K-25 Site

Figure 3.61. Noncombustible Physical Matrix Distribution for Oak Ridge National Laboratory, K-25 Site

Figure 3.62. Radiological Distribution for Oak Ridge National Laboratory, K-25 Site

Figure 3.63. Physical Matrix Distribution for Oak Ridge National Laboratory, Y-12 Plant

Figure 3.64. Combustible vs Noncombustible for Oak Ridge National Laboratory, Y-12 Plant

Figure 3.65. Combustible Physical Matrix Distribution for Oak Ridge National Laboratory, Y-12 Plant

Figure 3.66. Noncombustible Physical Matrix Distribution for Oak Ridge National Laboratory, Y-12 Plant

Figure 3.67. Radiological Distribution for Oak Ridge National Laboratory, Y-12 Plant

Figure 3.68. Physical Matrix Distribution for Paducah Gaseous Diffusion Plant

Figure 3.69. Combustible vs Noncombustible for Paducah Gaseous Diffusion Plant

Figure 3.70. Combustible Physical Matrix Distribution for Paducah Gaseous Diffusion Plant

Figure 3.71. Noncombustible Physical Matrix Distribution for Paducah Gaseous Diffusion Plant

Figure 3.72. Radiological Distribution for Paducah Gaseous Diffusion Plant

Figure 3.73. Physical Matrix Distribution for Pantex Plant

Figure 3.74. Combustible vs Noncombustible for Pantex Plant

Figure 3.75. Combustible Physical Matrix Distribution for Pantex Plant

Figure 3.76. Noncombustible Physical Matrix Distribution for Pantex Plant 
Figure 3.77. Radiological Distribution for Pantex Plant

Figure 3.78. Physical Matrix Distribution for Portsmouth Gaseous Diffusion Plant

Figure 3.79. Combustible vs Noncombustible for Portsmouth Gaseous Diffusion Plant

Figure 3.80. Combustible Physical Matrix Distribution for Portsmouth Gaseous Diffusion Plant

Figure 3.81. Noncombustible Physical Matrix Distribution for Portsmouth Gaseous Diffusion Plant

Figure 3.82. Radiological Distribution for Portsmouth Gaseous Diffusion Plant

Figure 3.83. Physical Matrix Distribution for Puget Sound Naval Shipyard

Figure 3.84. Combustible vs Noncombustible for Puget Sound Naval Shipyard

Figure 3.85. Combustible Physical Matrix Distribution for Puget Sound Naval Shipyard

Figure 3.86. Noncombustible Physical Matrix Distribution for Puget Sound Naval Shipyard

Figure 3.87. Radiological Distribution for Puget Sound Naval Shipyard

Figure 3.88. Physical Matrix Distribution for Rocky Flats Plant

Figure 3.89. Combustible vs Noncombustible for Rocky Flats Plant

Figure 3.90. Combustible Physical Matrix Distribution for Rocky Flats Plant

Figure 3.91. Noncombustible Physical Matrix Distribution for Rocky Flats Plant

Figure 3.92. Radiological Distribution for Rocky Flats Plant

Figure 3.93. Physical Matrix Distribution for Sandia National Laboratories

Figure 3.94. Combustible vs Noncombustible for Sandia National Laboratories

Figure 3.95. Combustible Physical Matrix Distribution for Sandia National Laboratories

Figure 3.96. Noncombustible Physical Matrix Distribution for Sandia National Laboratories

Figure 3.97. Radiological Distribution for Sandia National Laboratories

Figure 3.98. Physical Matrix Distribution for Savannah River Site

Figure 3.99. Combustible vs Noncombustible for Savannah River Site

Figure 3.100. Combustible Physical Matrix Distribution for Savannah River Site

Figure 3.101. Noncombustible Physical Matrix Distribution for Savannah River Site

Figure 3.102. Radiological Distribution for Savannah River Site

Figure 3.103. Physical Matrix Distribution for Weldon Spring Site

Figure 3.104. Combustible vs Noncombustible for Weldon Spring Site

Figure 3.105. Combustible Physical Matrix Distribution for Weldon Spring Site

Figure 3.106. Noncombustible Physical Matrix Distribution for Weldon Spring Site

Figure 3.107. Radiological Distribution for Weldon Spring Site 
Table 1.1. DOE Facilities Included in the ITTS Study LLMW Characterization Database . . . . . 3

Table 1.2. Calculation of the Percentage of Contact-Handled DOE Low-Level Mixed Wastes Included in the ITTS Study Database $\ldots \ldots \ldots \ldots \ldots \ldots \ldots \ldots \ldots$

Table 2.1. Selected Waste Matrices Contained within the ITTS Study Database . . . . . . . 7

Table 2.2. Elemental Composition Breakdown for each Physical Matrix . . . . . . . . 8

Table 2.3. Radionuclides included in the ITTS Study Database $\ldots \ldots \ldots \ldots \ldots$

Table 2.4. Combustible Physical Matrices $\ldots \ldots \ldots \ldots \ldots \ldots \ldots \ldots \ldots \ldots \ldots$

Tables for Chapter 3 are located at the end of the report, beginning on page 22 .

Table 3.1. Quantities of Contact-Handled Low-Level Mixed Wastes

Table 3.2. Quantities of Contact-Handled Low-Level Mixed Wastes per Waste Category Located at Various DOE Sites

Table 3.3. DOE Complex Contact-Handled Low-Level Mixed Wastes per Waste Category

Table 3.4. Characteristics of Contact-Handled Low-Level Mixed Wastes Located at Various DOE Sites

Table 3.5. Elemental Composition of the Contact-Handled Low-Level Mixed Wastes Located at Various DOE Sites

Table 3.6. Elemental Composition of the DOE Complex Contact-Handled Low-Level Mixed Wastes

Table 3.7. Elemental Composition for Each Physical Matrix for the DOE Complex 


\section{ACRONYMS AND ABBREVIATIONS}

Abs

absorbed

AEC

Atomic Energy Commission

ANL-E

Argonne National Laboratory-East

Aque

aqueous

BNL

Brookhaven National Laboratory

$\mathrm{CH}$ contact-handled

DOE

Department of Energy

EPA

Environmental Protection Agency

$\mathrm{ER} / \mathrm{WM}$

Environment Restoration and Waste Management

ETEC Energy Technology Engineering Center

FEMP Fernald Environmental Management Project

FRP fiberglass reinforced polyester

Halo halogenated

HS Hanford Site

IDB Integrated Database

INEL Idaho National Engineering Laboratory

Inorg inorganic

ITTS Integrated Thermal Treatment System

LANL Los Alamos National Laboratory $\alpha$-LLMW alpha low-level mixed waste

LLMW low-level mixed waste

LLNL Lawrence Livermore National Laboratory mat material

MSP Middlesex Sampling Plant

MWIR Mixed Waste Integrated Report

N.O.S. not otherwise specified org organic

ORNL Oak Ridge National Laboratory PE polyethylene

PGDP Paducah Gaseous Diffusion Plant PP polypropylene PVC polyvinyl chloride 

research and development 


\section{Quantities and Characteristics of the Contact- Handled Low-Level Mixed Waste Streams for the DOE Complex}

\subsection{INTRODUCTION}

The Department of Energy (DOE) generates and stores large quantities of mixed wastes, which contain both chemically hazardous and radioactive species. Treatment of these mixed wastes must meet standards established by the Environmental Protection Agency (EPA) for specific hazardous contaminants regulated under the Resource Conservation and Recovery Act (RCRA) while also providing adequate control of the radionuclides. In May 1993, the DOE Office of Technology Development (EM-50) initiated the Integrated Thermal Treatment System (ITTS) Study, a system engineering assessment of a variety of mixed waste treatment processes. The thermal treatment systems included in the ITTS Study range from conventional incinerators, such as rotary kiln and controlled air systems, to more innovative but not yet established technologies, such as molten salt and molten metal waste destruction systems. ${ }^{1}$ The thrust of the study is to develop preconceptual designs and life-cycle cost estimates for a range of integrated thermal treatment systems. To do this, the physical and chemical characteristics of the DOE waste streams to be treated must be defined or estimated. This report describes the effort to estimate the DOE waste stream characteristics.

Much of the waste stored throughout the DOE complex was generated prior to the promulgation of current regulations. While several databases and waste volume inventories have been prepared during the past years, the purpose in developing them has usually been to meet regulatory requirements for the identification of specific contaminants. For these and other reasons, detailed data on the physical characteristics of the waste (bulk materials and contaminants) are not generally available.

The most current waste information is contained in U.S. Department of Energy Interim Mixed Waste Inventory Report: Waste Streams, Treatment Capacities and Technologies (MWIR report). ${ }^{2}$ This report is the most complete and up to date effort by DOE to estimate waste inventories and categories (an update to this report is in preparation and will be published in the first half of 1994). Unfortunately, this inventory does not provide the detail from which one can directly calculate the elemental composition ( $\mathrm{C}, \mathrm{O}, \mathrm{N}, \mathrm{H}, \mathrm{Cl}, \mathrm{S}, \mathrm{F}$, and inerts) required to perform engineering mass and energy balances for waste treatment systems. For the ITTS Study, this report was used to derive 
(using engineering judgement and process knowledge where available) the physical matrices ${ }^{a}$ of the wastes, which in turn were used to generate the elemental analysis contained within the ITTS Study LLMW Characterization Database. It is recognized that this database is not completely accurate, but it is believed to be adequate for the ITTS Study objectives, which are summarized below:

- Identify candidate mixed waste thermal treatment systems and perform a preconceptual design for each of these.

- Evaluate life-cycle costs for such treatment systems, including the preparation of residues for disposal and cost for disposal.

- Identify research and development needed to support the deployment of the most attractive systems.

As improvements to the DOE mixed waste inventory database are generated through site characterization efforts and other programs, the ITTS Study will be updated as appropriate.

The Idaho National Engineering Laboratory (INEL) waste stream information was obtained from two EG\&G Idaho, Inc. reports that contained more detailed waste characterization information than required for the MWIR report, Identification of a Treatment Process for the Idaho Waste Processing Facility Project -- A Preconceptual Design Study ${ }^{h}$ and INEL Radioactive Waste Stream Characterization Data (DRAFT). ${ }^{3}$ The Preconceptual Design Study used a 1991 baseline. Since no waste generation rates were provided in this report, the INEL generation rates listed in the MWIR report were used to adjust the INEL data to the 1992 baseline.

The ITTS Study LLMW Characterization Database includes data from twenty DOE facilities, listed in Table 1.1. Certain waste streams, such as the Hanford tank waste and the Rocky Flats Plant solar pond liquids, have been excluded from the database as these waste streams are being addressed using other processes that are more suitable than thermal treatment. By including the major waste

a. The physical matrix is the material that is contaminated with hazardous substances or radioactive elements, e.g. a piece of cloth.

b. Roesener, W.S.; Soelberg, N.R.; Ayers, A.L., Jr.; Identification of a Treatment Process for the Idaho Waste Processing Facility Project -- A Preconceptual Design Study, unpublished work. 
Table 1.1 DOE Facilities Included in the ITTS Study LLMW Characterization Database

\begin{tabular}{ll} 
Argonne National Laboratory--East & Oak Ridge National Laboratory, K-25 Site \\
Brookhaven National Laboratory & Oak Ridge National Laboratory, Y-12 \\
& Plant \\
Energy Technology Engineering Center & Paducah Gaseous Diffusion Plant \\
Fernald Environmental Management Project & Pantex Plant \\
Hanford Site & Portsmouth Gaseous Diffusion Plant \\
Idaho National Engineering Laboratory & Puget Sound Naval Shipyard \\
Lawrence Livermore National Laboratory & Rocky Flats Plant \\
Los Alamos National Laboratory & Sandia National Laboratory \\
Middlesex Sampling Plant & Savannah River Site \\
Oak Ridge National Laboratory & Weldon Spring Site \\
& \\
\hline
\end{tabular}

streams $\left(>5 \mathrm{~m}^{3}\right)$ from each of the twenty facilities, the ITTS Study database encompasses $99.7 \%$ of the total contact-handled low-level mixed waste streams currently stored throughout the DOE complex (as reported in the MWIR report). This percentage was calculated using the formula in Table 1.2.

Stored waste volumes $\left(\mathrm{m}^{3}\right)$ were used to calculated this percentage since most of the sites reported their wastes in volumes. The only site which did not report volumes for its stored wastes was the Portsmouth Gaseous Diffusion Plant (PORTS). The MWIR report converted the PORTS total waste quantity $(\mathrm{kg})$ into a volume by using a generic density conversion. For the ITTS Study database, a density conversion value estimated for each waste stream was assigned to each of the PORTS waste streams. These two different approaches for assigning densities resulted in different volumes for the PORTS wastes. This volume difference is subtracted in the formula shown in Table 1.2. The ITTS Study database includes only contact-handled waste streams.

It was found that the physical matrices (wood, paper, building materials, sludges, etc.) of many of the DOE waste streams have not yet been defined. The physical waste matrix is the main information needed for determining an appropriate waste treatment technology. Therefore, using the best available information (i.e., waste descriptions and process knowledge), the DOE waste streams were segregated into their appropriate physical waste matrices. 
Table 1.2 Calculation of the Percentage of Contact-Handled DOE Low-Level Mixed Wastes Included in the ITTS Study Database

\begin{tabular}{|c|c|c|c|c|c|c|c|}
\hline & $\begin{array}{l}\text { Vol. from } \\
\text { MWIR Report } \\
\left(247,036 \mathrm{~m}^{3}\right)\end{array}$ & - & $\begin{array}{c}\text { INEL LLMW } \\
\text { from MWIR } \\
\text { Report } \\
\left(23,216 \mathrm{~m}^{3}\right)\end{array}$ & - & $\begin{array}{c}\text { RH LLMW from } \\
\text { MWIR Report } \\
\left(44,381 \mathrm{~m}^{3}\right)\end{array}$ & - & $\begin{array}{c}\text { Hanford Tank } \\
\text { Waste } \\
\left(40,086 \mathrm{~m}^{3}\right)\end{array}$ \\
\hline- & $\begin{array}{c}\text { RFP Solar Pond } \\
\text { Waste } \\
\left(45,425 \mathrm{~m}^{3}\right)\end{array}$ & + & $\begin{array}{l}\text { Difference in } \\
\text { PORTS due to } \\
\text { density } \\
\left(1,639 \mathrm{~m}^{3}\right)\end{array}$ & + & $\begin{array}{c}\text { INEL CH } \\
\text { LLMW from } \\
\text { EG\&G } \\
\text { Report } \\
\left(18,655 \mathrm{~m}^{3}\right)\end{array}$ & $=$ & $\begin{array}{l}\text { Possible Amount } \\
\text { of Waste for } \\
\text { inclusion in } \\
\text { ITTS Study } \\
\text { database } \\
\left(114,222 \mathrm{~m}^{3}\right)\end{array}$ \\
\hline & $\begin{array}{l}\text { Vol. from ITTS } \\
\left(113,901 \mathrm{~m}^{3}\right)\end{array}$ & $\div$ & $\begin{array}{c}\text { Possible Amount } \\
\text { of Wastes } \\
\left(114,222 \mathrm{~m}^{3}\right)\end{array}$ & $\mathrm{X}$ & 100 & $=$ & $99.7 \%$ \\
\hline
\end{tabular}

These physical waste matrices were used to perform an elemental analysis using generally accepted elemental analysis data. From the elemental analysis, the heat value, inert fraction, moisture content, and acid gas precursors were calculated for each waste stream. 


\subsection{WASTE CHARACTERISTICS}

The ITTS Study LLMW Characterization Database is not a simple replica of other DOE waste inventory databases. This database breaks down each nominal waste stream into what are believed to be its principal physical matrices (i.e., the bulk materials). The physical matrices are the main drivers for selecting the appropriate treatment technology. This matrix information is, in turn, converted to elemental compositions. Elemental compositions are necessary to calculate mass and energy balances for the treatment processes. As stated in Section 1.0, DOE waste stream information has not been fully developed at the physical level. Much of the information reviewed contained data on the trace constituents that made the waste hazardous, but there is very little information on the major components (physical matrices) of the waste; many DOE sites' waste characterization activities have not yet been completed. For the purpose of the ITTS Study database, engineering judgement was used to estimate the waste matrices where data were not available.

One of the challenges of compiling the waste stream data was to convert all of the data to a single format that would facilitate transformation of listed descriptions into elemental compositions. The primary source of waste stream information was the MWIR report. ${ }^{2}$ Most of these data were based on waste quantities through the end of 1992, although data for some sites were only valid through 1991. In these cases, annual generation rates were used to convert the data to the 1992 baseline. Since the database was to be linked to a mass balance program, the information needed to be in mass units. Consequently, bulk densities had to be estimated for the waste streams for which mass units were not reported. Bulk density estimations are documented within the database.

\subsection{Container Selection}

It was unclear in the MWIR report whether the waste masses listed included container mass or not. It was assumed that the mass for most of the waste streams included the container mass. An INEL study ${ }^{c}$ indicated that 55-gallon steel drums are the dominant container at the INEL, and that $4 \times 4 \times 7$ FRP (fiberglass reinforced polyester) wooden boxes represent the majority of the remaining waste containers. This was used as the basis for the container selection distribution for the remaining DOE sites included in the ITTS Study LLMW Characterization Database. Container types were

c. Hyde, R. A., EG\&G Idaho, Inc., letter to Fred Feizollahi of M-K Environmental Services, Inc., March 10, 1992. 
assigned based on the waste characteristics (i.e., high density, powder, or liquid wastes were assigned to drums and the remaining wastes were assigned to FRP boxes). If information becomes available on the actual container type, the data can be easily updated. Since the total estimated container mass is a substantial fraction of the total mass, the ITTS Study included container processing as part of the waste feed stream. The database is currently limited to two container types, drums and FRP boxes.

The specifications for the drums were obtained from an EG\&G Idaho repoit. ${ }^{b}$ Drums have a tare weight of $23.6 \mathrm{~kg}$ and a $5.8 \mathrm{~kg}$ polyethylene (PE) liner. FRP boxes were assumed to be $57 \%$ wood, $40 \%$ glass, and 3\% PE; no differentiation is made between the polyethylene of the liner and the polyester coating, both are assumed to be $\mathrm{PE}{ }^{4}$ The polyethylene liner, wood, and resin were included in the combustible waste, while the steel and the fiberglass were included in the non-combustible waste.

\subsection{Physical Matrix Distribution}

The physical waste matrix is the main factor used in determining the appropriate waste treatment technology. Therefore, using the best available information (i.e., waste descriptions and process knowledge), the DOE waste streams were segregated into assumed physical waste matrices. The MWIR report's waste profile sheets were used to obtain generic waste stream descriptions and the EPA waste codes were used to determine the hazardous contaminants for each waste stream.

The INEL waste stream data, obtained from the EG\&G Idaho report, ${ }^{b}$ were already broken down into resolvable physical matrices. The matrices list from this report was used as the initial matrix list for the ITTS Study LLMW Characterization Database. Other matrices were added to the database as needed while entering data from the MWIR Report (See Table 2.1).

Assigning waste matrix distributions to the waste stream data from the MWIR Report was difficult. The descriptions of the individual waste streams are frequently nebulous and involve mixtures of numerous materials. Should future revisions to the MWIR report include additional information that clarifies the actual waste matrix distribution of a given waste stream, the new distribution can be entered into the database and a revised elemental analysis can be generated. In spite of the inevitable uncertainties associated with the generation of the present database, it is judged to be suitable to meet objectives of the ITTS Study. 
Table 2.1 Selected Waste Matrices Contained within the ITTS Study Database

\begin{tabular}{lll}
\hline Glass Raschig Ring & Wood & Absorbed Organic \\
Misc. Glass & Cardboard & Absorbed Inorganic \\
Bulk (nontoxic) Metal & Organic Sludge & Soil/Dirt \\
Bulk Cadmium & Inorganic Sludge & Flooring Material \\
Bulk Barium & Cemented Organic Sludge & Asphalt \\
Uranium Compounds & Cemented Inorganic Sludge & Sheetrock \\
Beryllium & Cemented Resins & Concrete \\
Paint Residue & Resins & Metal Fines \& Turnings \\
Lead Shielding & Leaded Rubber & Diatomaceous Earth \\
Rubber & Ceramics (Molds \& Crucibles) & Bulk Mercury \\
Paper & Firebrick & Incinerator Ash \\
Cloth & Salts & Organic Labpacks \\
Oil & Halide Salts & Inorganic Labpacks \\
Plastic & Sulfate Salts & Tantalum (INEL) \\
PE/PP & Nitrate Salts & Non-Halogenated Organic Liquids \\
PVC & Aqueous Organics & Halogenated Organic Liquids \\
TFE & Aqueous Toxic Metals & Graphite \\
Batteries $(\mathrm{Pb}, \mathrm{Cd})$ & Aqueous Cyanides & \\
& & \\
\hline
\end{tabular}

\subsection{Elemental Composition}

All waste matrices were converted to their elemental compositions, which are needed to calculate mass and energy balances for the treatment processes. The elemental composition breakdowns for each physical matrix were obtained from numerous references. ${ }^{4,5,6,7,8,9,10,11,12, d}$ All sources of information used to generate the elemental compositions are documented within the database. Table 2.2 presents the elemental break-down used for each physical matrix identified within the ITTS Study database.

d. Personal communication with Texaco technical personnel. 







\subsection{Radiological Distribution}

One of the essential pieces missing in the waste inventory puzzle is radionuclide information. Unfortunately, a document listing chemical, physical, and radionuclide data for the waste streams was not found. ${ }^{2,3,713,14,15, \mathrm{~b}}$ Waste stream information listed in documents that focus on radionuclide contamination were found not to correspond with waste stream information listed in documents that focus on chemical contamination.

General radioactivity information was obtained from the Integrated Database (IDB) report. ${ }^{13}$ However, this report does not list specific radioactivity data for DOE low-level mixed wastes; therefore, the radioactivity information on low-level wastes was applied to the wastes in the LLMW Characterization Database.

Radionuclides selected for inclusion in the database are summarized in Table 2.3. The IDB Report placed the radionuclides into the following radiological categories: Alpha, Fission Products, Induced Activity, Tritium, Uranium/Thorium, and Other. The IDB report defines the "Other" category as containing unknown radionuclides and/or a mixture of radionuclides from multiple radiological categories. Assigning these data to a distribution of specific radionuclides was performed using information obtained from "Radiation and Mixed Waste Incineration, Background Information Document Volume 2: Risks of Radiation Exposure $^{115}$ and the MWIR waste profile sheets. The radiological distribution is based on the weight
Table 2.3 Radionuclides Included in the ITTS Study Database

$\begin{array}{cccc}\text { Alpha } & \begin{array}{c}\text { Fission } \\ \text { Products }\end{array} & \begin{array}{c}\text { Induced } \\ \text { Activity }\end{array} & \text { Tritium } \\ \text { Am-241 } & \text { Ba-137 } & \text { Co-58 } & \text { H-3 } \\ \text { Pu-239 } & \text { Ce-144 } & \text { Co-60 } & \\ \text { Pu-241 } & \text { Cs-134 } & \text { Cr-51 } & \text { Uranium/Thorium } \\ & \text { Cs-137 } & \text { Fe-59 } & \text { Pa-234 } \\ & \text { Nb-95 } & \text { Mn-54 } & \text { Th-234 } \\ & \text { Pr-144 } & \text { Tc-99 } & \text { U-235 } \\ & \text { Rh-106 } & \text { Zn-65 } & \text { U-238 } \\ \text { Ru-106 } & & \\ \text { Sb-125 } & & \\ \text { Sr-90 } & & \\ \text { Te-125m } & & \\ \text { Y-90 } & & \\ \text { Zr-95 } & & \end{array}$

\section{Other}

This category is made up of a combination of any of the above radionuclides. 
percent of the waste that is contaminated with the radionuclides contained within a radiological category.

\subsection{Heating Value Calculations}

The heating value for each waste stream was calculated based on the individual heating values for elemental carbon, hydrogen, sulfur, chlorine, and fluorine. ${ }^{6}$ After the amount of each elemental constituent was calculated, it was multiplied by its heating value. These values for each waste stream were summed and then divided by the total mass of the waste stream to obtain the average heating value for individual waste streams:

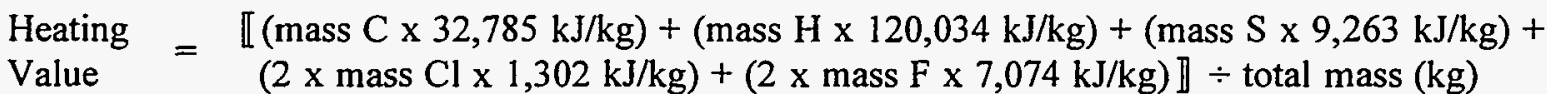

\subsection{Density Calculations}

The density for each waste stream was either assumed based on descriptions given for individual waste streams or calculated if both the mass and volume were given. If the volume for a waste stream was not given, it was then calculated based on the number of drums and bins documented. Generic volumes representing a 55-gallon drum $\left(0.208 \mathrm{~m}^{3}\right)$ and an FRP box $\left(3.17 \mathrm{~m}^{3}\right)$ were used.

\subsection{Moisture Content Determination}

As part of the elemental composition breakdown, the amount of water contained in each individual physical matrix was calculated. The moisture content fraction was computed by dividing the amount of water present by the total mass of the waste stream.

\subsection{Combustible Matter Determination}

The amount of combustible matter in each waste stream was calculated using the physical matrices that contained the largest amount of organic material (combustibles). The physical matrices chosen are summarized in Table 2.4. In addition, the combustible portions of the drum liners and FRP boxes were also included in the combustible matter calculations. All of the chosen physical matrices, excluding absorbed organics and organic labpacks, had an organic composition of eighty percent or 
Table 2.4 Combustible Physical Matrices

$\begin{array}{lll}\text { Rubber } & \text { Organic Labpacks } & \text { Cardboard } \\ \text { Paper } & \text { Halogenated Organic Liquids } & \text { Absorbed Organics } \\ \text { Cloth } & \text { Polyethylene/Polypropylene (PE/PP) } & \text { Non-Halogenated Organic Liquids } \\ \text { Oil } & \text { Polyvinyl chloride (PVC) } & \text { Graphite } \\ \text { Plastic N.O.S. } & \text { Teflon (TFE) } & \\ \text { Organic Sludge } & \text { Wood } & \\ & & \\ \end{array}$

greater. Absorbed organics and organic labpacks were also identified as combustible materials because of the large variability in their waste make-up. For example, organic liquids can be absorbed into either an inorganic matrix (kitty litter) or an organic matrix (sawdust).

The masses of the chosen physical matrices plus the combustible portion of the containers were summed and then divided by the total mass of the waste stream to obtain the combustible fraction.

\subsection{Acid Gas Precursor Calculations}

The compounds chosen as acid gas precursors were sulfur, sulfur dioxide, chlorine, and fluorine. The mass of the above compounds was summed and then divided by the total mass of the waste stream to calculate the fraction that has the potential to produce acidic gases. 


\subsection{WASTE INVENTORIES}

The ITTS Study LLMW Characterization Database provides an inventory of DOE's contacthandled LLMW. The reclassified TRU waste ( $\alpha$-LLMW) is also included in the ITTS Study database. The Rocky Flats Plant aqueous solar pond wastes and the Hanford Site tank wastes have been excluded from the ITTS Study database.

\subsection{Argonne National Laboratory--East}

Argonne National Laboratory--East (ANL-E) is a multi-program research and development laboratory located in Argonne, Illinois. Activities include nuclear reactor design, synchrotron radiation acceleration design, and environmental research programs. ${ }^{2}$ ANL-E currently stores approximately $156,292,790 \mathrm{~kg}$ of contact-handled LLMW.

\subsection{Brookhaven National Laboratory}

Brookhaven National Laboratory (BNL) is operated for the DOE by Associated Universities, Inc. BNL is located in Brookhaven Township on Long Island, New York. The laboratory conducts basic and applied research in the physical, biomedical, and environmental sciences and selected energy technologies. Waste generating activities are laboratory experiments and the cleaning and maintenance of laboratory equipment. ${ }^{2}$ BNL currently stores approximately $76,770 \mathrm{~kg}$ of contact-handled LLMW.

\subsection{Energy Technology Engineering Center}

Energy Technology Engineering Center (ETEC), located in southern California, develops energy technologies, and engineers, tests, and develops components related to liquid-metals technology in support of the DOE. ${ }^{2}$ ETEC currently stores approximately $1,260,470 \mathrm{~kg}$ of contact-handled LLMW.

\subsection{Fernald Environmental Management Project}

The Fernald Environmental Management Project (FEMP) is located in southwestern Ohio. The FEMP facility was built to process uranium ore concentrates into high purity uranium-metal 
products. A wide variety of chemical and metallurgical processing steps supported manufacturing of uranium-metal products for use at other DOE sites. On July 10, 1989, after more than 36 years of production, operations were suspended to refocus site resources on environmental restoration. ${ }^{2}$ FEMP currentiy stores approximately $3,404,104 \mathrm{~kg}$ of contact-handled LLMW.

\subsection{Hanford Site}

The Hanford Site (HS) is located in south-central Washington, immediately northwest of Richland. Historically, the primary mission of the site was the production of special nuclear material for defense. Hanford no longer has a defense production role, and the mission is now environmental restoration and waste management (ER/WM), technology development for ER/WM, and research and development on related topics. ${ }^{2}$ HS currently stores approximately $5,216,444 \mathrm{~kg}$ of contact-handled LLMW, excluding the tank wastes.

\subsection{Idaho National Engineering Laboratory}

The Idaho National Engineering Laboratory (INEL) is located in southeastern Idaho. The INEL was established in 1949 to conduct research and development on nuclear reactors and related equipment; since that time, 52 reactors have been built on-site and 12 are still operating or operable. The INEL is a multi-program laboratory whose primary mission is to provide the nation with innovations in nuclear technologies and unique scientific and engineering capabilities in non-nuclear programs that provide commercialization potential or enhance the quality of the environment. ${ }^{2}$ INEL currently stores approximately $15,708,380 \mathrm{~kg}$ of contact-handled LLMW.

\subsection{Lawrence Livermore National Laboratory}

Lawrence Livermore National Laboratory (LLNL) is located on the eastern edge of Livermore, California. LLNL is operated by the University of California for the DOE. Its primary mission is nuclear-weapons research and development, although LLNL also performs research on inertial confinement fusion, laser isotope separation, magnetic fusion energy, energy and resources, environmental restoration and waste management, and biomedical topics. ${ }^{2}$ LLNL currently stores approximately $194,429 \mathrm{~kg}$ of contact-handled LLMW. 


\subsection{Los Alamos National Laboratory}

Los Alamos National Laboratory (LANL) is located in Los Alamos County, New Mexico. LANL is operated for the DOE by the University of California. The prime mission of the laboratory is the design and development of nuclear weapons; however, considerable research and development $(R \& D)$ is directed toward controlled thermonuclear reactions, fission, nuclear safeguards, laser fusion, and medium energy physics. LANL has hazardous waste contaminated with activation or fusion products. $^{2}$ LANL currently stores approximately $1,149,677 \mathrm{~kg}$ of contact-handled LLMW.

\subsection{Middlesex Sampling Plant}

The Middlesex Sampling Plant (MSP) is located in Middlesex, New Jersey. The MSP facility was established in 1943 by the Manhattan Engineer District to sample, store, and/or ship uranium, thorium, and beryllium ores. In 1955, the Atomic Energy Commission (AEC) terminated the operation and later used the site for the storage and limited sampling of thorium residues. In 1967, the AEC activities ceased, on-site structures were decontaminated, and the site was certified for unrestricted use. Between 1968 and 1980, the site was used by the General Services Administration and the Department of Navy. In 1980, custody was returned to the DOE, which then initiated remedial action to clean up the vicinity properties and portions of the landfill into which radioactive materials previously had been disposed. Wastes resulting from the cleanup activities were transported to the MSP for interim storage. ${ }^{2}$ MSP currently stores approximately $44,043,936 \mathrm{~kg}$ of contacthandled LLMW.

\subsection{Oak Ridge National Laboratory}

The Oak Ridge National Laboratory (ORNL) is located southwest of Oak Ridge, Tennessee. ORNL is a multipurpose research and development facility supporting energy technology through applied research in basic and physical sciences. These activities are conducted predominantly on small scales in over 900 individual $R \& D$ laboratories. These activities are diverse and frequently generate waste materials. Unlike production facilities that have well defined operations that produce consistent waste streams in large volumes, ORNL is characterized by numerous small, periodic operations that produce very large numbers of small volume waste streams. ${ }^{2}$ ORNL currently stores approximately $311,473 \mathrm{~kg}$ of contact-handled LLMW. 


\subsection{Oak Ridge National Laboratory, K-25 Site}

The Oak Ridge National Laboratory K-25 Site (ORNL K-25) is located southwest of Oak Ridge, Tennessee. ORNL K-25 was formerly known as the Oak Ridge Gaseous Diffusion Plant. The original mission of this site was the production of highly enriched uranium in support of the national defense programs; this site was later used to produce uranium hexafluoride for use as nuclear reactor fuel. The gaseous diffusion plant was shut down in 1987. ORNL K-25's mission now is primarily environmental restoration, waste management, and research and development of the advanced isotopeseparation technology.

ORNL K-25 stores and treats wastes for the entire Oak Ridge Reservation (ORNL, Y-12, K25) as well as off-site wastes (primarily from PORTS, PGDP, and FEMP) destined for the Toxic Substance Control Act (TSCA) incinerator. ${ }^{2}$ ORNL K-25 currently stores approximately $39,924,779 \mathrm{~kg}$ of contact-handled LLMW.

\subsection{Oak Ridge National Laboratory, Y-12 Plant}

The Oak Ridge National Laboratory Y-12 Plant (ORNL Y-12) is located southwest of Oak Ridge, Tennessee. ORNL Y-12 was originally built, in 1943, for the separation of uranium isotopes as part of the Manhattan Project; its role was later changed to manufacturing and developmental engineering. ORNL Y-12's current mission is to serve as a manufacturing technology center for key processes associated with nuclear weapons components and other applications of national importance. In addition, the ORNL Y-12 mission includes environmental restoration and waste management. ${ }^{2}$ ORNL Y-12 currently stores approximately $19,121,602 \mathrm{~kg}$ of contact-handled LLMW.

\subsection{Paducah Gaseous Diffusion Plant}

The Paducah Gaseous Diffusion Plant (PGDP) is located west of Paducah, Kentucky. The PGDP is operated for the DOE by Martin Marietta Energy Systems, Inc. The PGDP mission is to produce low-enrichment uranium for the nuclear power industry. Mixed waste has been generated as a result of operations conducted in performing this mission. ${ }^{2}$ PGDP currently stores approximately $235,035 \mathrm{~kg}$ of contact-handled LLMW. 


\subsection{Pantex Plant}

The Pantex Plant (PXP) is located northeast of Amarillo, Texas. Activities include weapons production, maintenance, and modification, and disassembly of weapons retired for stockpile. ${ }^{2}$ PXP currently stores approximately $77,774 \mathrm{~kg}$ of contact-handled LLMW.

\subsection{Portsmouth Gaseous Diffusion Plant}

The Portsmouth Gaseous Diffusion Plant (PORTS) is located near Piketon, Ohio. Martin Marietta Energy Systems, Inc., operates the plant for DOE. The PORTS mission is to produce enriched uranium for the nuclear power industry. The following are mission-related PORTS activities that generate mixed waste:

- $\quad$ receipt and assay of $\mathrm{UF}_{6}$ process feed material;

- $\quad$ staged, porous barrier, U-235 enrichment;

- $\quad$ assay and shipment of enriched U-235 product material;

- facility maintenance and other supporting activities;

- environmental restoration;

- decontamination and decommissioning of obsolete equipment and facilities. ${ }^{2}$

PORTS currently stores approximately $6,327,194 \mathrm{~kg}$ of contact-handled LLMW.

\subsection{Puget Sound Naval Shipyard}

Puget Sound Naval Shipyard (PSNS) is located on the west side of Sinclair Inlet on Puget Sound, south of Bremerton, Washington. The shipyard is a U.S. Navy facility that repairs, overhauls, and maintains Navy ships, including nuclear-powered ships. Activities relating to naval propulsion systems are performed in accordance with the requirements and authority of the Naval Nuclear Propulsion Program, a joint DOE and Department of the Navy program. ${ }^{2}$ PSNS currently stores approximately $66,329 \mathrm{~kg}$ of contact-handled LLMW. 


\subsection{Rocky Flats Plant}

The Rocky Flats Plant (RFP) is located northwest of Denver, Colorado. RFP's historical mission was to produce plutonium and other metal components for nuclear weapons. Production activities included metal working, fabrication, and component assembly, as well as chemical recovery and purification of transuranic radionuclides. The plant used specialized facilities for recovery of nuclear components from obsolete weapons. RFP's new mission is to clean and stabilize production process systems, decontaminate obsolete or excess buildings and facilities, and process plutonium residues in preparation for transport to storage or disposal sites. RFP currently stores approximately $15,438,854 \mathrm{~kg}$ of contact-handled LLMW, excluding the aqueous solar pond waste stream.

\subsection{Sandia National Laboratory}

The Sandia National Laboratory (SNL) is located immediately southeast of Albuquerque, New Mexico, on Kirtland Air Force Base. SNL's primary mission is conducting R\&D in the interest of national security, with principal emphasis on development and engineering of non-nuclear components of nuclear weapons. Other programs include basic and applied research in the energy and materials sciences, nuclear waste management, and safeguards and security. ${ }^{2}$ SNL currently stores approximately $9,076 \mathrm{~kg}$ of contact-handled LLMW.

\subsection{Savannah River Site}

The Savannah River Site (SRS) is located south of Aiken, South Carolina, along the Savannah River. The primary mission of the SRS is the production of plutonium, tritium, and other special nuclear materials. The following SRS activities generate mixed wastes:

- $\quad$ plutonium recovery through separation processes;

- $\quad$ processing of enriched and depleted uranium;

- laboratory analytical testing and research;

- tritium production;

- bioassay studies;

- facility maintenance and other supporting activities; 
- decontamination and decommissioning of facilities;

- waste processing;

- environmental restoration. ${ }^{2}$

SRS currently stores approximately $3,505,594 \mathrm{~kg}$ of contact-handled LLMW.

\subsection{Weldon Spring Site}

Weldon Spring Site (WSS) is located west of St. Louis, Missouri. The site consists of a chemical plant and a limestone quarry. The U.S. Department of the Army used the chemical plant area as an ordnance works to produce nitroaromatic explosives in the 1940's, and the AEC processed uranium and thorium ores at the plant from 1957 to 1966. The EPA listed the quarry on its National Priorities List in 1987 and added the chemical plant area in 1989. The LLMW is composed of mostly drummed materials resulting from consolidation and containerization of waste chemicals abandoned at the facility. ${ }^{2}$ WSS currently stores approximately $64,549 \mathrm{~kg}$ of contact-handled LLMW.

\subsection{DOE Complex Totals}

Table $3.1^{\mathrm{e}}$ summarizes the quantities of contact-handled LLMW located at various DOE sites. The table category "net weights" represents the mass of only the wastes; the "total weight" category is the masses of both the waste and the containers. The drum mass includes both the weight of the drum $(23.6 \mathrm{~kg})$ and the weight of the polyethylene (PE) liner $(2.8 \mathrm{~kg})$. Tables 3.2 and 3.3 summarize the quantities of contact-handled LLMW contained in each waste category (the waste categories were obtained from the MWIR report). Table 3.4 summarizes the waste's physical characteristics that need to be known to adequately process the waste streams. These characteristics includes heat of combustion, density, moisture content, combustible matter, and acid gas precursors. Tables 3.5 and 3.6 summarize the elemental compositions of the DOE contact-handled LLMW streams. Table 3.7 summarizes the elemental composition for each physical matrix for the DOE complex.

e. For convenience in reading the text, the figures and tables for this chapter are given at the end of the report, beginning on page 22 . 
Figures 3.1 through 3.8 are various representations of the DOE complex LLMW. Figures 3.1 and 3.2 summarize the physical matrix distribution of the LLMW for the complex. Figures 3.3 and 3.4 identify the quantities of LLMW generated throughout the DOE complex. The Middlesex Sampling Plant (MSP) had the most LLMW as of December 31, 1992. Figures 3.5 and 3.6 graphically depict the combustible vs. noncombustible waste streams located throughout the DOE complex, with and without the drums and/or FRP boxes. The combustible fraction only changes $1 \%$ due to the combustible materials from the containers. Therefore, from here on, figures depicting the combustible vs. noncombustible waste streams will not include the containers. Figures 3.7 and 3.8 show the physical matrix distributions for the combustible and noncombustible wastes, respectively.

Figures 3.9 through 3.107 provide data on the LLMW streams for each of the sites, in alphabetical order. For each site, the first figure summarizes the physical matrix distribution for the LLMW, the second identifies the combustible portion of the LLMW, the third and fourth show the physical matrices that contribute to the combustible and noncombustible portions of waste streams, and the last identifies the radiological distribution for the LLMW stream at that site. 


\subsection{REFERENCES}

1. Feizollahi, F., Quapp, W. J., Hemphill, H. J., Groffie, F. J., Integrated Thermal Treatment System Study-Phase 1 Results, EGG-MS-11211, July 1994.

2. U.S. Department of Energy Interim Mixed Waste Inventory Report: Waste Streams, Treatment Capacities and Technologies, DOE/NBM-1100, April 1993.

3. Argyle M.D.; Rubert, A.L.; Tozer, J.C.; Meikle, L.; INEL Radioactive Waste Stream Characterization Data (DRAFT), EGG-WM-10909, August 1993.

4. Machine Design: Materials, Manufacturing, and Assembly Reference Volume, page 274, 1989.

5. Weast, Robert C., CRC Handbook of Chemistry and Physics, 63rd Edition, Boca Raton, Florida, 1983, Page C-223.

6. Perry, Robert H., Green, Don W., Chemical Engineer's Handbook, 6th Edition, 1984, Table 2629, 3-206 \& 3-207.

7. Grandy, J. D., et al., TSA Waste Stream and Final Waste Form Composition, EGG-MS-10617, January 1993, Table 4.

8. Science Applications International Corporation, Test Results from the Plasma Hearth Process Testing Under the Buried Waste Integrated Demonstration, SAIC report 93/1071, June 1993.

9. Parker, Sybil P., McGraw-Hill Dictionary of Scientific and Technical Terms, 4th Edition, New York, New York, 1989.

10. Science Applications International Corporation, Establishing BWID Thermal Treatment Compositions, SAIC report 92/1193, 1992.

11. Vlack, Van, Elements of Materials Science and Engineering, 4th Edition, Reading, Massachusetts, 1980.

12. Neissen, W.R., Combustion and Incineration Processes, New York, New York, 1978, Table 34.

13. Integrated Data Base for 1992: U.S. Spent Fuel and Radioactive Waste Inventories, Projections, and Characteristics, DOE/RW--0006-Rev.8, October 1992.

14. Nishimoto, D. D. and Wolfe, W. P., Establishing BWID Thermal Treatment Test Compositions, Engineering File Report SAIC-92/1193, September 1992. 
15. Radiation and Mixed Waste Incineration, Background Information Document Volume 2: Risks of Radiation Exposure, EPA 520/1-91-010-2, May 1991. 
Table 3.1. Quantities of Contacted-Handled Low-Level Mixed Wastes

Derived for the ITTS Study*

\begin{tabular}{|c|c|c|c|c|c|}
\hline 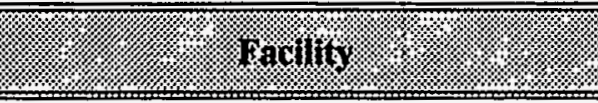 & 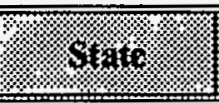 & Nor & (1) & smsors) & 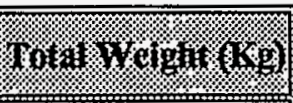 \\
\hline Total LLMW: & & $141,560,474$ & $10,055,196$ & $4,677,120$ & $156,292,790$ \\
\hline Argonne National Laboratory-East & Illinois & 142,892 & 12,848 & 580 & 156,320 \\
\hline Brookhaven National Laboratory & New York & 64,837 & 11,642 & 290 & 76,769 \\
\hline Energy Technology Engineering Center & California & $1,173,844$ & 85,466 & 1,160 & $1,260,470$ \\
\hline Fernald Environmental Management Project & Ohio & $2,987,064$ & 415,010 & 2,030 & $3,404,104$ \\
\hline $\begin{array}{c}\text { Hanford Site } \\
\end{array}$ & Washington & $4,494,859$ & 697,515 & 24,070 & $5,216,444$ \\
\hline Idaho National Engincering Laboratory & Idaho & $13,567,705$ & 835,385 & $1,305,290$ & $15,708,380$ \\
\hline Lawrence Livermore National Laboratory & California & 166,778 & 24,461 & 3,190 & 194,429 \\
\hline Los Alamos National Laboratory & New Mexico & $1,063,295$ & 67,532 & 18,850 & $1,149,677$ \\
\hline Middlesex Sampling Plant & New Jersey & $41,805,426$ & 0 & $2,238,510$ & $44,043,936$ \\
\hline Oak Ridge National Laboratory & Tennessee & 267,789 & 37,015 & 6,670 & 311,474 \\
\hline Oak Ridge National Laboratory, K-25 Site & Tennessee & $35,645,796$ & $4,263,323$ & 15,660 & $39,924,779$ \\
\hline Oak Ridge National Laboratory, Y-12 Plant & Tennessee & $17,496,920$ & $1,192,582$ & 432,100 & $19,121,602$ \\
\hline Paducah Gaseous Diffusion Plant & Kentucky & 203,037 & 28,518 & 3,480 & 235,035 \\
\hline Pantex Plant & Texas & 67,393 & 6,321 & 4,060 & 77,774 \\
\hline Portsmouth Gaseous Diffusion Plant & Ohio & $5,477,490$ & 577,975 & 271,730 & $6,327,195$ \\
\hline Puget Sound Naval Shipyard & Washington & 58,360 & 5,939 & 2,030 & 66,329 \\
\hline Rocky Flats Plant & Colorado & $13,970,130$ & $1,412,464$ & 56,260 & $15,438,854$ \\
\hline Sandia National Laboratories & New Mexico & 1,801 & 6,115 & 1,160 & 9,076 \\
\hline Savannah River Site & South Carolina & $2,851,122$ & 364,472 & 290,000 & $3,505,594$ \\
\hline Weldon Spring Site & Missouri & 53,936 & 10,613 & 0 & 64,549 \\
\hline
\end{tabular}


Table 3.2. Quantities of Contacted-Handled Low-Level Mixed Wastes per Waste Category Located at Various DOE Sites Derived for the ITTS Study*

\begin{tabular}{|c|c|c|c|c|c|}
\hline 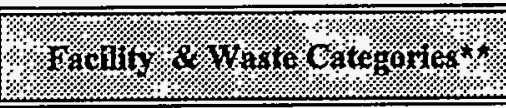 & 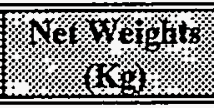 & 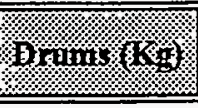 & thos & Wotagrejghi & 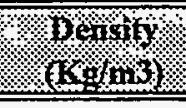 \\
\hline Total CH LLMW & $141,560,475$ & $10,055,191$ & $4,677,120$ & $156,292,787$ & \\
\hline \multicolumn{6}{|l|}{ Argonne National Laboratory-East } \\
\hline Site Total & $\underline{142,893}$ & $\underline{12,847}$ & $\underline{580}$ & $\underline{156,320}$ & \\
\hline Aqueous Liquids & 2,638 & $\overline{441}$ & 0 & 3,079 & 993 \\
\hline Elemental Lead & 60,912 & 0 & 580 & 61,492 & 11,387 \\
\hline Inorganic Sludge/Particulate & 45,117 & 6,585 & 0 & 51,702 & 1,096 \\
\hline Lab Packs without Metals & 30,460 & 4,586 & 0 & 35,046 & 1,082 \\
\hline Organic Debris & 1,118 & 382 & 0 & 1,500 & 600 \\
\hline Organic Liquids & 2,648 & 853 & 0 & 3,501 & 584 \\
\hline \multicolumn{6}{|l|}{ Brookhaven National Laboratory } \\
\hline Site Total & $\underline{64,837}$ & $\underline{11,642}$ & $\underline{290}$ & $\underline{76,770}$ & \\
\hline Elemental Lead & 1,348 & 0 & 290 & 1,638 & 1,092 \\
\hline Inorganic Sludge/Particulate & 44,196 & 7,673 & 0 & 51,869 & 957 \\
\hline Lab Packs with Metals & 5,952 & 794 & 0 & 6,746 & 1,205 \\
\hline Muitiple & 1,070 & 853 & 0 & 1,923 & 321 \\
\hline Organic Liquids & 12,271 & 2,323 & 0 & 14,594 & 890 \\
\hline \multicolumn{6}{|l|}{ Energy Technology Engineering Center } \\
\hline Site Total & $\underline{1,173,844}$ & $\underline{85,466}$ & $\underline{1,160}$ & $1,260,470$ & \\
\hline Elemental Lead & 55,420 & 0 & 580 & 56,000 & 11,200 \\
\hline Heterogeneous Debris & 3,243 & 647 & 580 & 4,470 & 417 \\
\hline Soils & $1,115,181$ & 84,819 & 0 & $1,200,000$ & 2,000 \\
\hline \multicolumn{6}{|l|}{ Fermald Environmental Management Project } \\
\hline Site Total & $\underline{2,987,067}$ & $\underline{415,007}$ & $\underline{2,030}$ & $\underline{3,404,104}$ & \\
\hline Aqueous Liquids & $1,034,181$ & $\overline{117,246}$ & 0 & $\overline{1,151,427}$ & 1,312 \\
\hline Inorganic Debris & 202,860 & 41,100 & 1,740 & 245,700 & 746 \\
\hline Inorganic Sludge/Particulate & 947,641 & 101,752 & 0 & $1,049,393$ & 1,185 \\
\hline Organic Liquids & 97,222 & 20,522 & 0 & 117,744 & 719 \\
\hline Organic Sludge/Particulate & 705,163 & 134,387 & 290 & 839,840 & 857 \\
\hline \multicolumn{6}{|l|}{ Hanford Site } \\
\hline Site Total & $4,494,859$ & $\underline{697,515}$ & $\underline{24,070}$ & $\underline{5,216,444}$ & \\
\hline Elemental Lead & 122,655 & 20,227 & 0 & 142,882 & 1,000 \\
\hline Heterogeneous Debris & 171,560 & 23,990 & 3,770 & 199,320 & 1,000 \\
\hline Inorganic Debris & 5,904 & 0 & 870 & 6,774 & 955 \\
\hline Inorganic Sludge/Particulate & $2,220,314$ & 365,560 & 0 & $2,585,874$ & 993 \\
\hline Lab Packs with Metals & 486,494 & 80,144 & 0 & 566,638 & 1,000 \\
\hline Lab Packs without Metals & 624,871 & 103,017 & 0 & 727,888 & 994 \\
\hline Liquid Mercury & 13,040 & 2,176 & 0 & 15,216 & 962 \\
\hline Organic Debris & 385,435 & 63,475 & 0 & 448,910 & 1,000 \\
\hline Organic Sludge/Particulate & 347,968 & 27,136 & 18,560 & 393,664 & 998 \\
\hline Reactive Metals & 7,380 & 0 & 870 & 8,250 & 971 \\
\hline Soils with $<50 \%$ Debris & 109,238 & 11,790 & 0 & 121,028 & 1,332 \\
\hline \multicolumn{6}{|l|}{ Idaho National Engineering Laboratory } \\
\hline Site Total & $\underline{13,567,705}$ & $\underline{835,386}$ & $1,305,290$ & $\underline{15,708,380}$ & \\
\hline Aqueous Liquids & 112,949 & 17,257 & 0 & 130,206 & 840 \\
\hline Contaminated Metals & 39,582 & 0 & 4,060 & 43,642 & 960 \\
\hline Elemental Lead & 3,739 & 59 & 0 & 3,798 & 687 \\
\hline Heterogeneous Debris & $1,756,918$ & 27,048 & 223,300 & $2,007,266$ & 824 \\
\hline Inorganic Debris & 779,915 & 94,992 & 55,390 & 930,297 & 691 \\
\hline Inorganic Sludge/Particulate & $3,129,433$ & 392,893 & 15,370 & $3,537,696$ & 973 \\
\hline Multiple & $6,088,181$ & 112,567 & 978,170 & $7,178,918$ & 421 \\
\hline Organic Debris & 224 & 0 & 4,640 & 4,864 & 62 \\
\hline Organic Liquids & 19,290 & 2,851 & 0 & 22,141 & 896 \\
\hline Organic Sludge/Particulate & $1,148,527$ & 138,415 & 1,740 & $1,288,682$ & 795 \\
\hline Reactive Metals & 9,299 & 0 & 3,480 & 12,779 & 246 \\
\hline Soils & 479,649 & 49,304 & 19,140 & 548,093 & 847 \\
\hline
\end{tabular}


Table 3.2. Quantities of Contacted-Handled Low-Level Mixed Wastes per Waste Category Located at Various DOE Sites Derived for the ITTS Study*

\begin{tabular}{|c|c|c|c|c|c|}
\hline 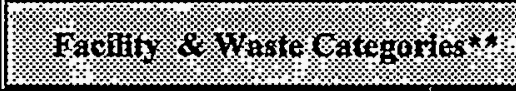 & Ho urejols & 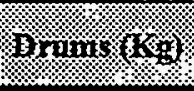 & 6oxes/k. & 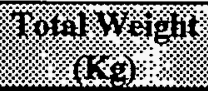 & \%olstor \\
\hline \multicolumn{6}{|l|}{ Lawrence Livermore National Laboratory } \\
\hline Site Total & 166,777 & $\underline{24,462}$ & $\underline{3,190}$ & $\underline{194.429}$ & \\
\hline Aqueous Liquids & 21,243 & 3,557 & 0 & 24,800 & 992 \\
\hline Cemented Solids & 34,439 & 4,263 & 0 & 38,702 & 1,290 \\
\hline Heterogeneous Debris & 9,931 & 0 & 2,320 & 12,251 & 490 \\
\hline Inorganic Debris & 5,473 & 0 & 870 & 6,343 & 555 \\
\hline Inorganic Sludge/Particulate & 37,380 & 5,968 & 0 & 43,348 & 1,099 \\
\hline Lab Packs without Metals & 968 & 441 & 0 & 1,409 & 470 \\
\hline Organic Liquids & 53,432 & 9,644 & 0 & 63,076 & 873 \\
\hline Soils & 3,912 & 588 & 0 & 4,500 & 1,125 \\
\hline \multicolumn{6}{|l|}{ Los Alamos National Laboratory } \\
\hline Site Total & $1,063,295$ & $\underline{67,532}$ & $\underline{18,850}$ & $\underline{1,149,677}$ & \\
\hline Aqueous Liquids & 24,020 & 3,116 & 0 & 27,136 & 1,080 \\
\hline Heterogeneous Debris & 2,590 & 3,704 & 0 & 6,294 & 100 \\
\hline Inorganic Debris & 548,220 & 470 & 17,110 & 565,800 & 2,550 \\
\hline Lab Packs with Metals & 5,400 & 529 & 0 & 5,929 & 1,500 \\
\hline Liquid Mercury & 105,000 & 1,499 & 0 & 106,499 & 10,000 \\
\hline Organic Debris & 5,070 & 0 & 1,740 & 6,810 & 300 \\
\hline Organic Liquids & 92,620 & 18,140 & 0 & 110,760 & 1,000 \\
\hline Other & 271,900 & 38,455 & 0 & 310,355 & 1,000 \\
\hline Reactive Metals & 8,475 & 1,617 & 0 & 10,092 & 750 \\
\hline \multicolumn{6}{|l|}{ Middlesex Sampling Plant } \\
\hline Site Total & $\underline{41,805,426}$ & $\underline{0}$ & $2,238,510$ & $\underline{44,043,936}$ & \\
\hline Inorganic Debris & $41,805,426$ & 0 & $2,238,510$ & $44,043,936$ & 1,800 \\
\hline \multicolumn{6}{|l|}{ Oak Ridge National Laboratory } \\
\hline$\underline{\text { Site Total }}$ & $\underline{267,789}$ & $\underline{37,013}$ & $\underline{6,670}$ & $\underline{311,472}$ & \\
\hline Aqueous Liquids & 37,044 & 6,115 & 0 & 43,159 & 1,000 \\
\hline Multiple & 153,322 & 28,899 & 0 & 182,221 & 1,056 \\
\hline Organic Liquids & 12,001 & 1,999 & 0 & 14,000 & 1,000 \\
\hline Other & 65,422 & 0 & 6,670 & 72,092 & 1,000 \\
\hline \multicolumn{6}{|l|}{ Oak Ridge National Laboratory, K-25 Site } \\
\hline Site Total & $\underline{35,645,795}$ & $4,263,324$ & $\underline{15,660}$ & $\underline{39,924,779}$ & \\
\hline Aqueous Liquids & 46,799 & 7,321 & 0 & 54,120 & 1,102 \\
\hline Inorganic Debris & 234,674 & 970 & 13,630 & 249,274 & 2,955 \\
\hline Inorganic Sludge/Particulates & $31,561,439$ & $3,744,002$ & 0 & $35,305,441$ & 1,333 \\
\hline Liquid Mercury & 245,785 & 2,558 & 0 & 248,343 & 13,797 \\
\hline Multiple & $1,408,112$ & 170,079 & 0 & $1,578,191$ & 1,668 \\
\hline Organic Debris & 49,446 & 8,556 & 0 & 58,002 & 981 \\
\hline Organic Liquids & $1,348,525$ & 233,937 & 0 & $1,582,462$ & 1,049 \\
\hline Organic Sludge/Particulates & 503,479 & 56,742 & 0 & 560,221 & 1,021 \\
\hline Other & 247,535 & 39,160 & 2,030 & 288,725 & 974 \\
\hline \multicolumn{6}{|l|}{ Oak Ridge National Laboratory, Y-12 Plant } \\
\hline Site Total & $\underline{17,496,920}$ & $\underline{1,192,582}$ & 432,100 & $19,121,602$ & \\
\hline Aqueous Liquids & 13,987 & 2,323 & 0 & 16,309 & 1,005 \\
\hline Multiple & $9,948,247$ & $1,044,582$ & 0 & $10,992,829$ & 1,294 \\
\hline Organic Liquids & 843,425 & 138,944 & 0 & 982,369 & 1,000 \\
\hline Organic Sludge/Particulates & 40,962 & 6,733 & 0 & 47,695 & 999 \\
\hline Soils & $6,650,300$ & 0 & 432,100 & $7,082,400$ & 1,500 \\
\hline
\end{tabular}


Table 3.2. Quantities of Contacted-Handled Low-Level Mixed Wastes per Waste Category Located at Various DOE Sites Derived for the ITTS Study*

\begin{tabular}{|c|c|c|c|c|c|}
\hline 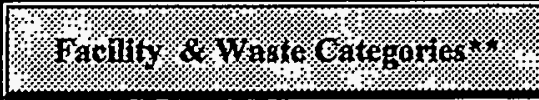 & Hetrowto & Trums & 300x & Mong & mowst \\
\hline \multicolumn{6}{|l|}{ Paducah Gaseous Diffusion Plant } \\
\hline Site Total & $\underline{203,037}$ & $\underline{28,518}$ & $\underline{3,480}$ & $\underline{235,035}$ & \\
\hline Aqueous Liquids & 5,014 & 853 & 0 & 5,867 & 1,005 \\
\hline Batteries & 1,491 & 265 & 0 & 1,756 & 1,001 \\
\hline Compressed Gases & 1,869 & 323 & 0 & 2,192 & 996 \\
\hline Heterogeneous Debris & 21,462 & 0 & 2,320 & 23,782 & 1,001 \\
\hline Inorganic Debris & 12,741 & 470 & 1,160 & 14,371 & 1,006 \\
\hline Inorganic Sludge/Particulates & 22,320 & 3,704 & 0 & 26,024 & 1,007 \\
\hline Lab Packs with Metals & 25,815 & 4,263 & 0 & 30,078 & 1,001 \\
\hline Multiple & 10,860 & 1,823 & 0 & 12,683 & 995 \\
\hline Organic Debris & 30,641 & 5,057 & 0 & 35,698 & 1,001 \\
\hline Organic Liquids & 36,794 & 6,086 & 0 & 42,880 & 1,005 \\
\hline Organic Sludge/Particulates & 8,650 & 1,441 & 0 & 10,091 & 999 \\
\hline Other & 25,379 & 4,234 & 0 & 29,613 & 998 \\
\hline \multicolumn{6}{|l|}{ Pantex Plant } \\
\hline Site Total & $\underline{67,393}$ & 6,321 & 4,060 & $\underline{77,774}$ & \\
\hline Aqueous Liquids & 3,171 & 529 & 0 & 3,700 & 1,000 \\
\hline Batteries & 3,335 & 265 & 0 & 3,600 & 2,000 \\
\hline Heterogeneous Debris & 4,920 & 0 & 580 & 5,500 & 1,000 \\
\hline Inorganic Sludge/Particulates & 11,680 & 0 & 1,160 & 12,840 & 1,200 \\
\hline Multiple & 39,427 & 4,763 & 2,320 & 46,510 & 850 \\
\hline Organic Liquids & 4,860 & 764 & 0 & 5,624 & 900 \\
\hline \multicolumn{6}{|l|}{ Portsmouth Gaseous Diffusion Plant } \\
\hline Site Total & $\underline{5,477,489}$ & $\underline{577,976}$ & $\underline{271,730}$ & $\underline{6,327,195}$ & \\
\hline Aqueous Liquids & 56,455 & 8,056 & 0 & 64,511 & 1,069 \\
\hline Batteries & 7,014 & 500 & 0 & 7,514 & 2,000 \\
\hline Compressed Gases & 773 & 0 & 870 & 1,643 & 100 \\
\hline Heterogeneous Debris & 249,858 & 22,197 & 120,930 & 392,985 & 350 \\
\hline Inorganic Debris & 59,342 & 1,205 & 13,630 & 74,177 & 943 \\
\hline Inorganic Sludge/Particulates & 203,940 & 25,107 & 0 & 229,047 & 1,133 \\
\hline Lab Packs with Metals & 22,649 & 3,498 & 0 & 26,147 & 733 \\
\hline Liquid Mercury & 121 & 29 & 0 & 151 & 13,000 \\
\hline Multiple & 1,020 & 147 & 0 & 1,167 & 1,000 \\
\hline Organic Debris & 191,846 & 1,118 & 134,850 & 327,814 & 240 \\
\hline Organic Liquids & 153,326 & 24,639 & 0 & 177,965 & 930 \\
\hline Organic Sludge/Particulates & 9,049 & 2,058 & 0 & 11,107 & 750 \\
\hline Soils & $4,522,095$ & 489,422 & 1,450 & $5,012,967$ & 1,400 \\
\hline \multicolumn{6}{|l|}{ Puget Sound Naval Shipyard } \\
\hline Site Total & $\underline{58,360}$ & $\underline{5,939}$ & $\underline{2,030}$ & $\underline{66,329}$ & \\
\hline Cemented Solids & 49,412 & 5,380 & 0 & 54,792 & 1,418 \\
\hline Heterogeneous Debris & 6,314 & 0 & 1,740 & 8,054 & 528 \\
\hline Organic Debris & 2,635 & 559 & 290 & 3,484 & 610 \\
\hline \multicolumn{6}{|l|}{ Rocky Flats Plant } \\
\hline Site Total & $\underline{13,970,130}$ & $1,412,462$ & $\underline{56,260}$ & $\underline{15,438,852}$ & \\
\hline Aqueous Liquids & 11,130 & 1,528 & 0 & 12,658 & 1,050 \\
\hline Beryllium Dust & 300 & 235 & 0 & 535 & 200 \\
\hline Cemented Solids & 190,800 & 706 & 8,410 & 199,916 & 2,000 \\
\hline Elemental Lead & 287,100 & 0 & 3,190 & 290,290 & 9,000 \\
\hline Inorganic Debris & 265,440 & 7,203 & 44,660 & 317,303 & 1,183 \\
\hline Inorganic Sludge/Particulates & $13,058,180$ & $1,377,065$ & 0 & $14,435,245$ & 1,412 \\
\hline Multiple & 11,540 & 2,969 & 0 & 14,509 & 666 \\
\hline Organic Liquids & 145,640 & 22,756 & 0 & 168,396 & 925 \\
\hline
\end{tabular}


Table 3.2. Quantities of Contacted-Handled Low-Level Mixed Wastes per Waste Category Located at Various DOE Sites Derived for the ITTS Study*

\begin{tabular}{|c|c|c|c|c|c|}
\hline 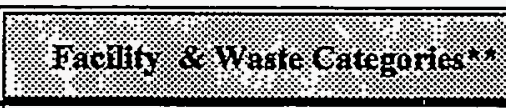 & We whong & Homing & Why & 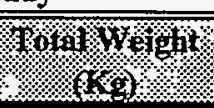 & 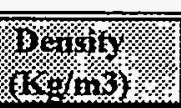 \\
\hline \multicolumn{6}{|l|}{ Sandia National Laboratory } \\
\hline Site Total & $\underline{1,801}$ & 6,115 & $\underline{1,160}$ & 9,077 & \\
\hline Other & $\overline{1,801}$ & 6,116 & 1,160 & 9,077 & 40 \\
\hline \multicolumn{6}{|l|}{ Savannah River Site } \\
\hline Site Total & $2.851,122$ & $\underline{364,471}$ & 290,000 & $3,505,593$ & \\
\hline Aqueous Liquids & 824,777 & 136,563 & 0 & 961,340 & 1,040 \\
\hline Elemental Lead & 198,605 & 0 & 26,390 & 224,995 & 759 \\
\hline Inorganic Debris & 8,878 & 0 & 6,670 & 15,548 & 192 \\
\hline Inorganic Sludge/Particulates & $1,293,410$ & 171,843 & 0 & $1,465,253$ & 1,155 \\
\hline Organic Debris & 419,882 & 37,838 & 256,940 & 714,660 & 309 \\
\hline Organic Liquids & 84,952 & 15,640 & 0 & 100,592 & 961 \\
\hline Soils & 20,618 & 2,587 & 0 & 23,205 & 1,282 \\
\hline \multicolumn{6}{|l|}{ Weldon Spring Site } \\
\hline Site Total & $\underline{53,936}$ & $\underline{10,613}$ & $\underline{0}$ & $\underline{64,549}$ & \\
\hline Aqueous Liquids & $\overline{8,841}$ & $\overline{1,794}$ & $\overline{0}$ & $\overline{10,635}$ & 696 \\
\hline Batteries & 1,842 & 617 & 0 & 2,459 & 585 \\
\hline Elemental Lead & 1,370 & 176 & 0 & 1,546 & 1,288 \\
\hline Inorganic Sludge/Particulates & 5,749 & 1,470 & 0 & 7,219 & 795 \\
\hline Lab Packs with Metals & 1,568 & 529 & 0 & 2,097 & 567 \\
\hline Multiple & 1,772 & 294 & 0 & 2,066 & 1,087 \\
\hline Organic Liquids & 32,795 & 5,732 & 0 & 38,527 & 799 \\
\hline
\end{tabular}

* Quantities obtained from the DOENNBM-1100 (MWIR Report), April 1993. The Hanford tank waste (40,086 Kg) and the RFP aqueous solar pond waste $(45,425 \mathrm{Kg})$ were excluded.

** Waste Categories were obtained from the DOE/NBM-1100 (MWIR Report), April 1993. 
Table 3.3. DOE Complex Contacted-Handled Low-Level Mixed Wastes per Waste Category - Derived for the ITTS Study*

\begin{tabular}{|c|c|c|c|c|c|}
\hline \%/2 & Weturging & minsotes & 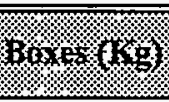 & 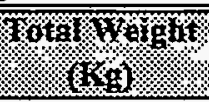 & 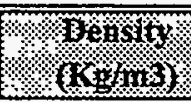 \\
\hline Total CH LLMW & $141,560,474$ & $10,055,195$ & $\overline{4,677,120}$ & $156,292,790$ & \\
\hline Aqueous Liquids & $2,202,248$ & 306,701 & 0 & $2,508,949$ & 1,013 \\
\hline Batteries & 13,682 & 1,646 & 0 & 15,329 & 1,397 \\
\hline Beryllium Dust & 300 & 235 & 0 & 535 & 200 \\
\hline Cemented Solids & 274,651 & 10,349 & 8,410 & 293,409 & 1,570 \\
\hline Compressed Gases & 2,642 & 323 & 870 & 3,835 & 548 \\
\hline Contaminated Metals & 39,581 & 0 & 4,060 & 43,642 & 960 \\
\hline Elemental Lead & 731,148 & 20,462 & 31,030 & 782,640 & 3,252 \\
\hline Heterogeneous Debris & $2,226,795$ & 77,587 & 355,540 & $2,659,923$ & 635 \\
\hline Inorganic Debris & $43,928,872$ & 146,412 & $2,394,240$ & $46,469,524$ & 1,240 \\
\hline Inorganic Sludge/Particulates & $52,580,798$ & $6,203,626$ & 16,530 & $58,800,954$ & 1,109 \\
\hline Lab Packs with Metals & 547,877 & 89,758 & 0 & 637,636 & 1,001 \\
\hline Lab Packs without Metals & 656,299 & 108,045 & 0 & 764,343 & 849 \\
\hline Liquid Mercury & 363,947 & 6,262 & 0 & 370,209 & 7,722 \\
\hline Multiple & $17,663,553$ & $1,366,976$ & 980,490 & $20,011,019$ & 946 \\
\hline Organic Debris & $1,086,298$ & 116,983 & 398,460 & $1,601,741$ & 567 \\
\hline Organic Liquids & $2,939,802$ & 504,827 & 0 & $3,444,629$ & 902 \\
\hline Organic Sludge/Particulate & $2,763,797$ & 366,912 & 20,590 & $3,151,299$ & 917 \\
\hline Other & 612,037 & 87,965 & 9,860 & 709,861 & 802 \\
\hline Reactive Metals & 25,154 & 1,617 & 4,350 & 31,121 & 656 \\
\hline Soils & $12,791,755$ & 626,720 & 452,690 & $13,871,165$ & 1,359 \\
\hline Soils with $<50 \%$ Debris & 109,239 & 11,789 & 0 & 121,028 & 1,332 \\
\hline
\end{tabular}

* Quantities obtained from the DOE/NBM-1100 (MWIR Report), April 1993. The Hanford tank waste (40,086 Kg) and the RFP aqueous solar pond waste $(45,425 \mathrm{Kg})$ were excluded.

** Waste Categories were obtained from the DOE/NBM-1100 (MWIR Report), April 1993. 
Table 3.4. Characteristics of Contacted-Handled Low-Level Mixed Wastes

Located at Various DOE Sites Derived for the ITTS Study*

\begin{tabular}{|c|c|c|c|c|c|c|c|}
\hline 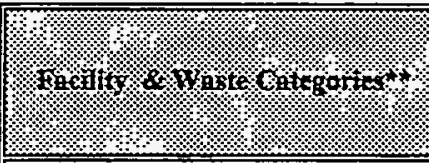 & 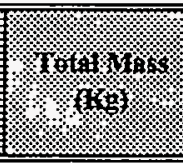 & 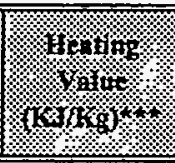 & 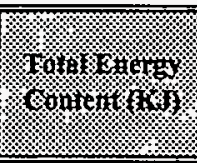 & 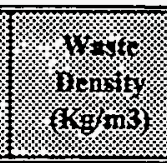 & 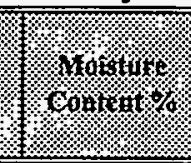 & 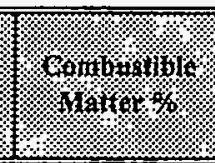 & 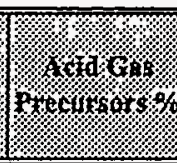 \\
\hline \multicolumn{8}{|l|}{ Argonne National Laboratory-East } \\
\hline Aqueous Liquids & 3,079 & 1,640 & $5.05 \mathrm{E}+06$ & 993 & 75 & 3 & $\mathbf{0}$ \\
\hline Elemental Lead & 61,492 & 126 & $7.75 E+06$ & 11,387 & 0 & 1 & 0 \\
\hline Inorganic Sludge/Particulate & 51,702 & 2,687 & $1.39 \mathrm{E}+08$ & 1,096 & 38 & 2 & 0 \\
\hline Lab Packs without Metals & 35,046 & 6,260 & $2.19 E+08$ & 1,082 & 0 & 90 & 0 \\
\hline Organic Debris & 1,500 & 5,150 & $7.73 \mathrm{E}+06$ & 600 & 69 & 9 & 1 \\
\hline Organic Liquids & 3,501 & 39,717 & $1.39 E+08$ & 584 & $\mathbf{0}$ & 80 & 0 \\
\hline \multicolumn{8}{|l|}{ Brookhaven National Laboratory } \\
\hline Elemental Lead & 1,638 & 2,939 & $4.81 E+06$ & 1,092 & 1 & 11 & 0 \\
\hline Inorganic Sludge/Particulate & 51,869 & 1,544 & $8.01 \mathrm{E}+07$ & 957 & 38 & 3 & 0 \\
\hline Lab Packs with Metals & 6,746 & 4,493 & $3.03 \mathrm{E}+07$ & 1,205 & 37 & 16 & 0 \\
\hline Multiple & 1,923 & 31,165 & $5.99 \mathrm{E}+07$ & 321 & 0 & 64 & 0 \\
\hline \begin{tabular}{|l} 
Organic Liquids \\
\end{tabular} & 14,594 & 44,379 & $6.48 \mathrm{E}+08$ & 890 & 3 & 87 & 0 \\
\hline \multicolumn{8}{|l|}{ Energy Technology Engineering Center } \\
\hline Elemental Lead & 56,000 & 138 & $7.73 E+06$ & 11,200 & 0 & 1 & 0 \\
\hline Heterogeneous Debris & 4,470 & 31,788 & $1.42 E+08$ & 417 & 10 & 27 & 0 \\
\hline Soils & $1,200,000$ & 1,242 & $1.49 \mathrm{E}+09$ & 2,000 & 8 & 1 & 4 \\
\hline \multicolumn{8}{|l|}{ FernaId Environmental Management Project } \\
\hline Aqueous Liquids & $1,151,427$ & 36,893 & $4.25 \mathrm{E}+10$ & 1,312 & 67 & 6 & $\mathbf{0}$ \\
\hline Inorganic Debris & 245,700 & 113,052 & $2.78 \mathrm{E}+10$ & 746 & 5 & 17 & 5 \\
\hline Inorganic Sludge/Particulate & $1,049,393$ & 131,929 & $1.38 \mathrm{E}+11$ & 1,185 & 7 & 7 & 21 \\
\hline Organic Liquids & 117,744 & 605,136 & $7.13 E+10$ & 719 & 12 & 66 & 12 \\
\hline Organic Sludge/Particulate & 839,840 & 683,947 & $5.74 \mathrm{E}+11$ & 857 & 6 & 66 & 6 \\
\hline \multicolumn{8}{|l|}{ Hanford Site } \\
\hline Elemental Lead & 142,882 & 1,551 & $2.22 \mathrm{E}+08$ & 1,000 & 1 & 3 & 1 \\
\hline Heterogeneous Debris & 199,320 & 162,320 & $3.24 \mathrm{E}+10$ & 1,000 & 2 & 47 & 6 \\
\hline Inorganic Debris & 6,774 & 11,593 & 7.85E +07 & 955 & 2 & 56 & 10 \\
\hline Inorganic Sludge/Particulate & $2,585,874$ & 21,922 & $5.67 \mathrm{E}+10$ & 993 & 15 & 21 & 5 \\
\hline Lab Packs with Metals & 566,638 & 19,161 & $1.09 \mathrm{E}+10$ & 1,000 & 0 & 89 & 0 \\
\hline Lab Packs without Metals & 727,888 & 43,661 & $3.18 \mathrm{E}+10$ & 994 & 0 & 85 & 0 \\
\hline Liquid Mercury & 15,216 & 5,814 & 8.85E+07 & 962 & 2 & 20 & 1 \\
\hline Organic Debris & 448,910 & 27,507 & $1.23 E+10$ & 1,000 & 3 & 89 & 6 \\
\hline Organic Sludge/Particulate & 393,664 & 54,712 & $2.15 \mathrm{E}+10$ & 998 & 5 & 71 & 7 \\
\hline Reactive Metals & 8,250 & 1,555 & $1.28 E+07$ & 971 & 0 & 6 & 0 \\
\hline Soils with $<50 \%$ Debris & 121,028 & 5,030 & $6.09 E+08$ & 1,332 & 7 & 2 & 4 \\
\hline \multicolumn{8}{|l|}{ Idaho National Engineering Laboratory } \\
\hline Aqueous Liquids & 130,205 & 76,284 & $9.93 E+09$ & 840 & 54 & 24 & 3 \\
\hline Contaminated Metals & 43,642 & 1,353 & $5.90 E+07$ & 960 & 0 & 6 & 0 \\
\hline Elemental Lead & 3,798 & 140 & $5.32 \mathrm{E}+05$ & 687 & 0 & 0 & $\mathbf{0}$ \\
\hline Heterogeneous Debris & $2,007,266$ & 297,644 & $5.97 \mathrm{E}+11$ & 824 & 1 & 34 & 1 \\
\hline Inorganic Debris & 930,297 & 125,366 & $1.17 \mathrm{E}+11$ & 691 & 3 & 24 & 0 \\
\hline Inorganic Sludge/Particulate & $3,537,696$ & 192,680 & $6.82 \mathrm{E}+11$ & 973 & 13 & 15 & 6 \\
\hline Multiple & $7,178,918$ & 101,855 & $7.31 \mathrm{E}+11$ & 421 & 1 & 42 & 1 \\
\hline Organic Debris & 4,864 & 294,314 & $1.43 \mathrm{E}+09$ & 62 & 3 & 62 & 0 \\
\hline Organic Liquids & 22,141 & 189,947 & $4.21 E+09$ & 896 & 9 & 79 & 0 \\
\hline Organic Sludge/Particulate & $1,288,682$ & 99,581 & $1.28 \mathrm{E}+11$ & 795 & 2 & 86 & 10 \\
\hline Reactive Metals & 12,779 & 4,937 & $631 E+07$ & 246 & 1 & 16 & 0 \\
\hline Soils & 548,093 & 3,020 & $1.66 \mathrm{E}+09$ & 847 & 7 & 7 & 3 \\
\hline \multicolumn{8}{|l|}{ Lawrence Livermore National Laboratory } \\
\hline Aqueous Liquids & 24,800 & 1,643 & 4.07E+07 & 992 & 75 & 3 & 0 \\
\hline Cemented Solids & 38,702 & 1,101 & $4.26 \mathrm{E}+07$ & 1,290 & 39 & 2 & 0 \\
\hline Heterogeneous Debris & 12.251 & 21,066 & $2.58 \mathrm{E}+08$ & 490 & 3 & 67 & 2 \\
\hline Inorganic Debris & 6,343 & 172,891 & $1.10 E+09$ & 555 & 2 & 32 & 0 \\
\hline Inorganic Sludge/Particulate & 43,348 & 3,338 & $1.45 E+08$ & 1,099 & 13 & 2 & 2 \\
\hline Lab Packs without Metals & 1,409 & 7,814 & 1. $10 E+07$ & 470 & 0 & 58 & $\mathbf{0}$ \\
\hline $\begin{array}{l}\text { Organic Liquids } \\
\text { Soils }\end{array}$ & $\begin{array}{r}63,076 \\
4,500 \\
\end{array}$ & $\begin{array}{r}111,168 \\
1.874 \\
\end{array}$ & $\begin{array}{l}7.01 E+09 \\
8.43 E+06\end{array}$ & $\begin{array}{r}873 \\
1,125 \\
\end{array}$ & $\begin{array}{l}7 \\
7\end{array}$ & $\begin{array}{r}79 \\
3 \\
\end{array}$ & $\begin{array}{r}21 \\
3\end{array}$ \\
\hline
\end{tabular}


Table 3.4. Characteristics of Contacted-Handled Low-Level Mixed Wastes Located at Various DOE Sites Derived for the ITTS Study*

\begin{tabular}{|c|c|c|c|c|c|c|c|}
\hline 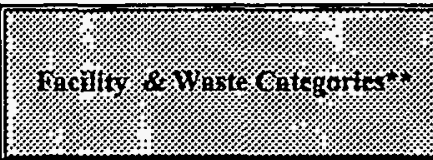 & 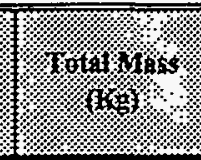 & \%oring & 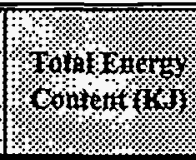 & 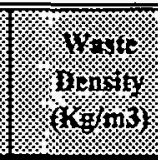 & 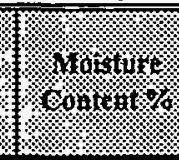 & 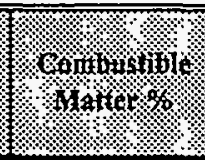 & 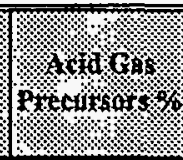 \\
\hline \multicolumn{8}{|c|}{ Los Alamos National Laboratory } \\
\hline Aqueous Liquids & 27,136 & 18,475 & $5.01 \mathrm{E}+08$ & 1,080 & 70 & 11 & 3 \\
\hline Heterogeneous Debris & 6,294 & 96,511 & $6.07 E+08$ & 100 & 1 & 43 & 1 \\
\hline Inorganic Debris & 565,800 & 2,002 & I.13E+09 & 2,550 & 0 & 1 & 0 \\
\hline Lab Packs with Metals & 5,929 & 5,793 & $3.43 \mathrm{E}+07$ & 1,500 & 0 & 93 & $\mathbf{0}$ \\
\hline Liquid Mercury & 106,499 & 1,178 & $1.25 E+08$ & 10,000 & 13 & 5 & 0 \\
\hline Organic Debris & 6,810 & 25,095 & $1.71 E+08$ & 300 & 5 & 90 & o \\
\hline Organic Liquids & 110,760 & 117,648 & $1.30 \mathrm{E}+10$ & 1,000 & 0 & 81 & 30 \\
\hline Other & 310,355 & 26,821 & $8.32 E+09$ & 1,000 & 48 & 33 & 3 \\
\hline Reactive Metals & 10,092 & 2,243 & $2.26 \mathrm{E}+07$ & 750 & $\mathbf{0}$ & 3 & 30 \\
\hline \multicolumn{8}{|l|}{ Middlesex Sampling Plant } \\
\hline Inorganic Debris & $44,043,936$ & 9,670 & $4.26 E+11$ & 1,800 & 2 & 32 & 2 \\
\hline \multicolumn{8}{|l|}{ Oak Ridge National Laboratory } \\
\hline Aqueous Liquids & 43,159 & 1,622 & $7.00 \mathrm{E}+07$ & 1,000 & 75 & 3 & 0 \\
\hline Multiple & 182,222 & 112,869 & $2.06 \mathrm{E}+10$ & 1,056 & 12 & 36 & 7 \\
\hline Organic Liquids & 14,000 & 38,335 & 5.37E+08 & 1,000 & 0 & 89 & 0 \\
\hline Other & 72,092 & 12,565 & $9.06 \mathrm{E}+08$ & 1,000 & 13 & 39 & 7 \\
\hline \multicolumn{8}{|l|}{ Oak Ridge National Leboratory, K-25 Site } \\
\hline Aqueous Liquids & 54,120 & 6,244 & $3.38 \mathrm{E}+08$ & 1,102 & 63 & 2 & 0 \\
\hline Inorganic Debris & 249,274 & 40,750 & $1.02 \mathrm{E}+10$ & 2,955 & 0 & 16 & 0 \\
\hline Inorganic Sludge/Particulates & $35,305,441$ & 1,055 & $3.72 \mathrm{E}+10$ & 1,333 & 39 & 2 & $\mathbf{0}$ \\
\hline Liquid Mercury & 248,343 & 93 & $2.31 E+07$ & 13,797 & $\mathbf{0}$ & 0 & 0 \\
\hline Multiple & $1,578,191$ & 104,423 & $1.65 E+11$ & 1,668 & 32 & 36 & 2 \\
\hline Orgaric Debris & 58,002 & 100,840 & $5.85 \mathrm{E}+09$ & 981 & 5 & 85 & 6 \\
\hline Organic Liquids & $1,582,462$ & 392,680 & $6.21 \mathrm{E}+11$ & 1,049 & 3 & 80 & 26 \\
\hline Organic Sludge/Particulates & 560,221 & 81,454 & $4.56 \mathrm{E}+10$ & 1,021 & 10 & 65 & 8 \\
\hline Other & 288,725 & 27,502 & $7.94 \mathrm{E}+09$ & 974 & 8 & 10 & 9 \\
\hline \multicolumn{8}{|l|}{ Oak Ridge Nationsl Laboratory, Y-12 Plant } \\
\hline Aqqueous Liquids & 16,309 & 1,630 & $2.66 \mathrm{E}+07$ & 1,005 & 75 & 3 & 0 \\
\hline Multiple & $10,992,829$ & 177,524 & $1.95 \mathrm{E}+12$ & 1,294 & 24 & 31 & 11 \\
\hline Organic Liquids & 982,369 & 19,424 & $1.91 E+10$ & 1,000 & 5 & 67 & 37 \\
\hline Organic Sludge/Particulates & 47,695 & 35,880 & $1.71 E+09$ & 999 & 4 & 89 & 9 \\
\hline Soils & $7,082,400$ & 8,080 & $5.72 \mathrm{E}+10$ & 1,500 & 14 & 22 & 4 \\
\hline \multicolumn{8}{|l|}{ Paducah Gaseous Diffusion Plent } \\
\hline Aqueous Liquids & 5,867 & 3,656 & $2.14 E+07$ & 1,005 & 79 & 3 & 0 \\
\hline Batteries & 1,756 & 2,296 & 4.03E+06 & 1,001 & 3 & 3 & 1 \\
\hline Compressed Gases & 2,192 & 1,737 & $3.81 E+06$ & 996 & 33 & 3 & 0 \\
\hline Heterogeneous Debris & 23,782 & 9,259 & $2.20 \mathrm{E}+08$ & $1,00 !$ & 9 & 30 & 2 \\
\hline Inorganic Debris & 14,371 & 4,999 & $7.18 \mathrm{E}+07$ & 1,006 & 0 & 5 & 26 \\
\hline Inorganic Sludge/Particulates & 26,024 & 20,744 & $5.40 \mathrm{E}+08$ & 1,007 & 24 & 8 & 1 \\
\hline Lab Packs with Metals & 30,078 & 15,761 & $4.74 E+08$ & 1,001 & 3 & 24 & 3 \\
\hline Multiple & 12,683 & 2,073 & $2.63 \mathrm{E}+07$ & 995 & 25 & 11 & 2 \\
\hline Organic Debris & 35,698 & 13,196 & 4.71E+08 & 1,001 & 16 & 37 & 3 \\
\hline Organic Liquids & 42,880 & 126,686 & $5.43 \mathrm{E}+09$ & 1,005 & 2 & 82 & 18 \\
\hline Organic Sludge/Particulates & 10,091 & 10,459 & $1.06 E+08$ & 999 & 0 & 89 & 72 \\
\hline Other & 29,613 & 22,145 & $6.56 \mathrm{E}+08$ & 998 & 24 & 35 & 2 \\
\hline \multicolumn{8}{|l|}{ Pantex Plant } \\
\hline Aqueous Liquids & 3,700 & 1,706 & 6.31E+06 & 1,000 & 76 & 3 & 0 \\
\hline Betteries & 3,600 & 1,423 & $5.12 E+06$ & 2,000 & 4 & 1 & 1 \\
\hline Heterogeneous Debris & 5,500 & 26,876 & $1.48 E+08$ & 1,000 & 3 & 46 & 2 \\
\hline Inorganic Sludge/Particulates & 12,840 & 1,310 & $1.68 \mathrm{E}+07$ & 1,200 & 24 & 5 & 0 \\
\hline Multiple & 46,510 & 63,752 & 2.97E+09 & 850 & $\mathbf{t}$ & 62 & 16 \\
\hline Organic Liquids & 5,624 & 38.253 & $2.15 \mathrm{E}+08$ & 900 & $\mathbf{0}$ & 89 & 0 \\
\hline
\end{tabular}


Table 3.4. Characteristics of Contacted-Handled Low-Level Mixed Wastes Located at Various DOE Sites Derived for the ITTS Study*

\begin{tabular}{|c|c|c|c|c|c|c|c|}
\hline 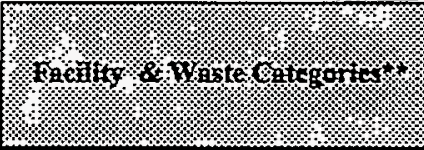 & 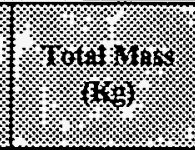 & 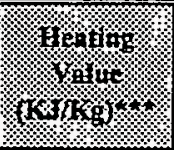 & 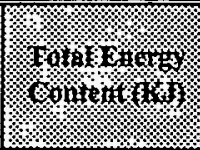 & 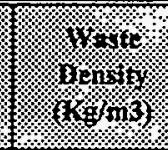 & א\%"x & 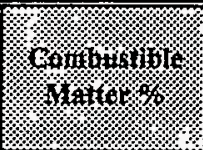 & 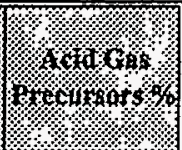 \\
\hline \multicolumn{8}{|l|}{ Portsmouth Gaseous Diffusion Plant } \\
\hline Aqueous Liquids & 64,510 & 31,817 & $2.05 E+09$ & 1,069 & 68 & 11 & 6 \\
\hline Batteries & 7,514 & 1,351 & $1.02 E+07$ & 2,000 & 4 & 1 & 1 \\
\hline Compressed Gases & 1,643 & 16,773 & $2.76 \mathrm{E}+07$ & 100 & 2 & 34 & 0 \\
\hline Heterogeneous Debris & 392,986 & 309,933 & $1.22 \mathrm{E}+11$ & 350 & s. & 53 & 3 \\
\hline Inorganic Debris & 74,177 & 82,704 & $6.13 E+09$ & 943 & $i$ & 23 & 1 \\
\hline Inorganic Sludge/Particulates & 229,047 & 38,206 & $8.75 E+09$ & 1,133 & 30 & 2 & o \\
\hline Lab Packs with Metals & 26,147 & 7,764 & $2.03 \mathrm{E}=08$ & 733 & 5 & 3 & $\mathbf{0}$ \\
\hline Liquid Mercury & 151 & 2,155 & $3.25 \mathrm{E}+05$ & 13,000 & 0 & 4 & 0 \\
\hline Multiple & 1,167 & 15,463 & $1.80 \mathrm{E}+07$ & 1,000 & 19 & 51 & 3 \\
\hline Organic Debris & 327,814 & 160,103 & $5.25 \mathrm{E}+10$ & 240 & 3 & 77 & 2 \\
\hline Organic Liquids & 177,964 & 382,711 & $6.81 \mathrm{E}+10$ & 930 & 9 & 78 & 15 \\
\hline Organic Sludge/Particulates & 11,107 & 115,331 & $1.28 \mathrm{E}+09$ & 750 & 5 & 61 & 5 \\
\hline Soils & $5,012,967$ & 3,014 & $1.51 \mathrm{E}+10$ & 1,400 & 7 & 3 & 4 \\
\hline \multicolumn{8}{|l|}{ Puget Sound Naval Shipyard } \\
\hline Cemented Solids & 54,791 & 2,123 & $1.16 \mathrm{E}+08$ & 1,418 & 7 & 2 & 0 \\
\hline Heterogeneous Debris & 8,054 & 87,367 & $7.04 \mathrm{E}+08$ & 528 & 2 & 70 & 3 \\
\hline Organic Debris & 3,483 & 47,731 & $1.66 \mathrm{E}+08$ & 610 & 2 & 67 & 0 \\
\hline \multicolumn{8}{|l|}{ Rocky Flats Plant } \\
\hline Aqueous Liquids & 12,658 & 3,576 & $4.53 \mathrm{E}+07$ & 1,050 & 81 & 3 & 0 \\
\hline Beryllium Dust & 535 & 9,029 & $4.83 E+06$ & 200 & 0 & 14 & 0 \\
\hline Cemented Solids & 199,916 & 10,680 & $2.14 \mathrm{E} \div 09$ & 2,000 & 4 & 2 & 1 \\
\hline Elemental Lead & 290,290 & 147 & $4.27 \mathrm{E}+07$ & 9,000 & 0 & 1 & 0 \\
\hline Inorganic Debris & 317,303 & 84,674 & $2.69 \mathrm{E}+10$ & 1,183 & 3 & 22 & $\mathbf{t}$ \\
\hline Inorgaric Sludge/Particulates & $14,435,245$ & 35,289 & $5.09 E+11$ & 1,412 & 8 & 4 & 1 \\
\hline Multiple & 14,509 & 42,317 & $6.14 \mathrm{E}+08$ & 666 & 16 & 42 & 2 \\
\hline Organic Liquids & 168,396 & 102,888 & $1.73 \mathrm{E}+10$ & 925 & 12 & 75 & 9 \\
\hline \multicolumn{8}{|l|}{ Sandia National Laboratory } \\
\hline Other & 9,075 & 850,924 & $7.72 \mathrm{E}+09$ & 39 & 2 & 33 & 0 \\
\hline \multicolumn{8}{|l|}{ Savannah River Site } \\
\hline Aqueous Liquids & 961,340 & 4,919 & $4.73 \mathrm{E}+09$ & 1,039 & 76 & 3 & $\mathbf{0}$ \\
\hline Elemental Lead & 224,995 & 2,953 & $6.64 E+08$ & 759 & 1 & 10 & 0 \\
\hline Inorganic Debris & 15,548 & 36,027 & $5.60 \mathrm{E}+08$ & 192 & 9 & 40 & o \\
\hline Inorganic Siudge/Particulates & $1,465,253$ & 3,750 & $5.49 E+09$ & 1,155 & 38 & 2 & 0 \\
\hline Organic Debris & 714,660 & 115,149 & $8.23 \mathrm{E}+10$ & 309 & 6 & 63 & 2 \\
\hline Organic Liquids & 100,592 & 144,482 & $1.45 \mathrm{E}+10$ & 961 & 1 & 73 & 15 \\
\hline Soils & 23,205 & 1,681 & $3.90 \mathrm{E}+07$ & 1,282 & 7 & 2 & 4 \\
\hline \multicolumn{8}{|l|}{ Weldon Spring Site } \\
\hline Aqueous Liquids & 10,635 & 10,864 & $1.16 \mathrm{E}+08$ & 696 & 72 & 4 & 0 \\
\hline Batteries & 2,459 & 3,699 & $9.10 \mathrm{E}+06$ & 585 & 3 & 5 & 1 \\
\hline Elemental Lead & 1,546 & 1,145 & $1.77 \mathrm{E}+06$ & 1,288 & 0 & 2 & 0 \\
\hline Inorganic Sludge/Particulates & 7,219 & 8,300 & $5.99 \mathrm{E}+07$ & 795 & 0 & 4 & 25 \\
\hline Lab Packs with Metals & 2,097 & 3,614 & $7.58 \mathrm{E}+06$ & 567 & 5 & 5 & 0 \\
\hline Multiple & 2,066 & 3,339 & $6.90 E+06$ & 1,087 & 0 & 4 & 52 \\
\hline Organic Liquids & 38,527 & 181,799 & $7.00 \mathrm{E}+09$ & 799 & 3 & 80 & 1 \\
\hline
\end{tabular}

- Quantities obtained from the DOE/NBM-1100 (MWIR Report), April 1993. The Hanford tank waste (40,086 Kg)

and the RFP aqueous solar pond waste $\{45,425 \mathrm{Kg})$ were excluded

-. Waste Categories were obtained form the DOE/NBM-1100 (MWIR Report), April 1993.

- Conversion formula: $(\mathrm{KJ} / \mathrm{KG}) \times 0.42985=\mathrm{BTU} / \#$ 


\begin{tabular}{|c|c|c|c|c|c|c|}
\hline mantis & & & & 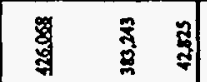 & & 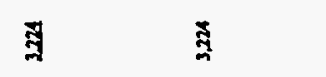 \\
\hline 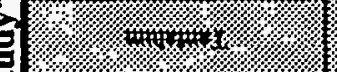 & & & & & & 羿 \\
\hline$\sqrt{-3}$ & $m$ & $\pi$ & & g然 & - & $g-8 s$ \\
\hline 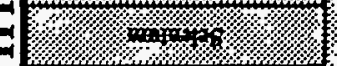 & $m$ & $m$ & & $8-$ & 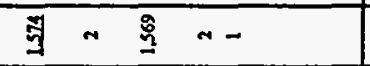 & $9 g \quad 9-g s$ \\
\hline $4=$ & $I=$ & 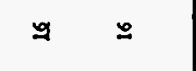 & & 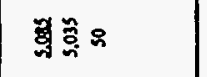 & 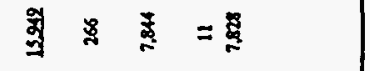 & 염믐 $\quad \therefore=2$ \\
\hline$\sqrt{2}$ & $\frac{\partial}{3}=\frac{\pi}{8}$ & 적을 & 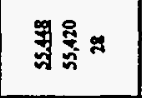 & 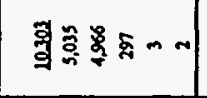 & 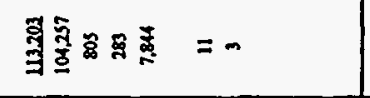 & 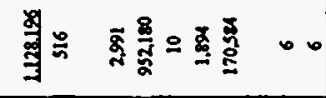 \\
\hline Imin & $g=\approx$ & $\approx$ สะ & & 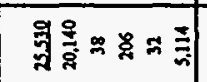 & 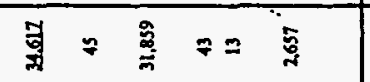 & 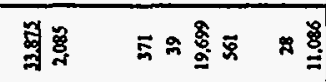 \\
\hline $4=$ & $\exists \approx \equiv$ & $g \cong 9$ & & 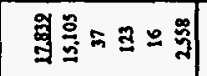 & 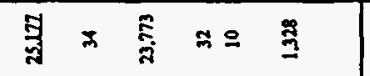 & 국 \\
\hline$=3:-1$ & & & & & & \\
\hline 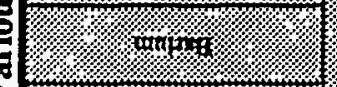 & $a m$ & $\div \quad-$ & & 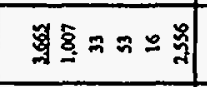 & 然 $\sim \frac{8}{2} \cdots-\frac{8}{2}$ & $g \equiv \quad 2-5 \approx n$ \\
\hline 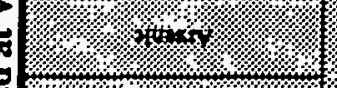 & $\cdots$ & $-\quad-$ & & 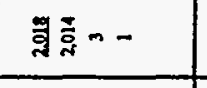 & $\mathrm{g}$ & 身㐘 $\quad=-8=$ \\
\hline 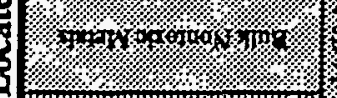 & 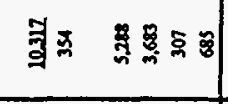 & 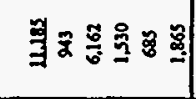 & 管喿 & 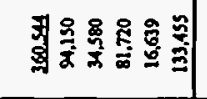 & 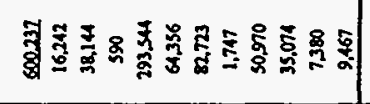 & 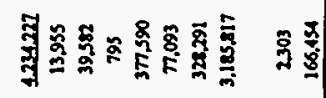 \\
\hline tris. & 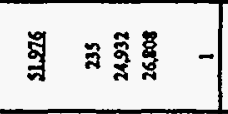 & 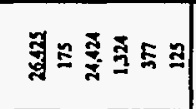 & 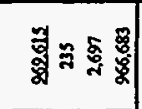 & 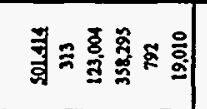 & 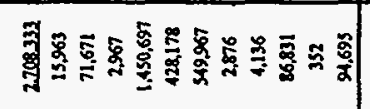 & 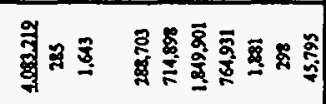 \\
\hline 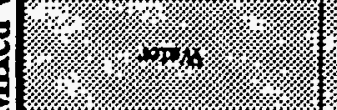 & 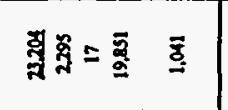 & 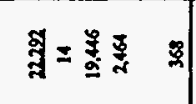 & 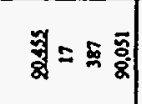 & 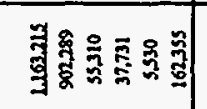 & 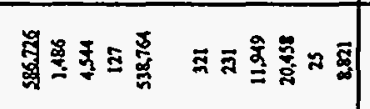 & 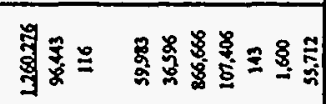 \\
\hline 100 & & & & 嫼 & 筫 & 50 \\
\hline 98 & & & & 羿羿 & 整 & 8 \\
\hline 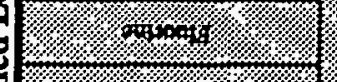 & & & & & $\Xi \equiv$ & 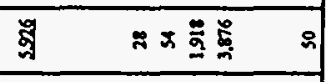 \\
\hline $4=$ & & & 氞 & 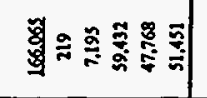 & 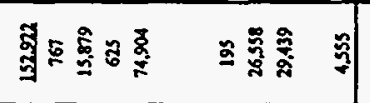 & 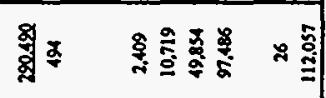 \\
\hline$-n=$ & & $a-8$ & & 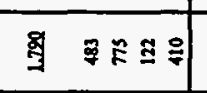 & 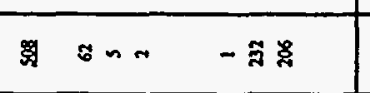 & 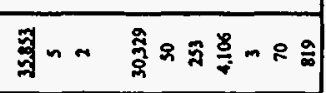 \\
\hline$\sqrt{12 \pi+20}$ & $\Rightarrow=$ & $5:$ & $\cdots$ & 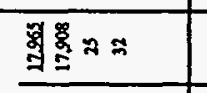 & $\exists x-\bar{x}=-\frac{1}{3}$ & 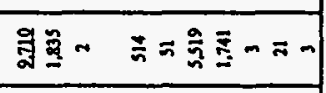 \\
\hline 280 & 워요 & $y=z=$ & $\exists \underline{y} \underline{\underline{z}}$ & 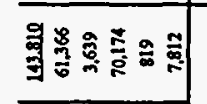 & 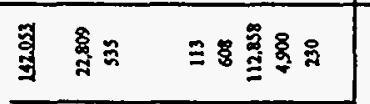 & 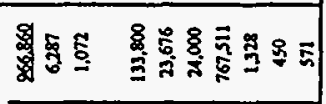 \\
\hline & 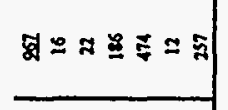 & & & 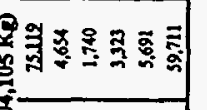 & 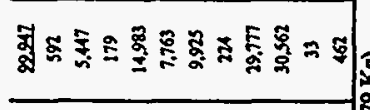 & 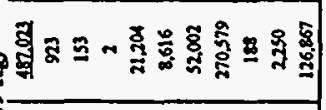 \\
\hline & & & $z=\bar{z}$ & 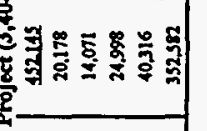 & 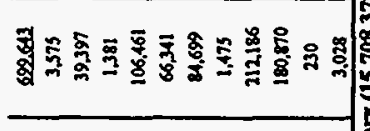 & 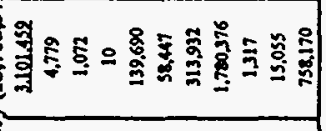 \\
\hline$=\frac{19}{4}$ & & 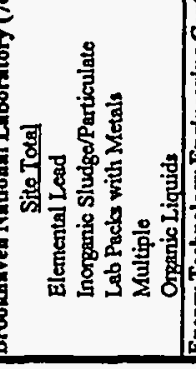 & & 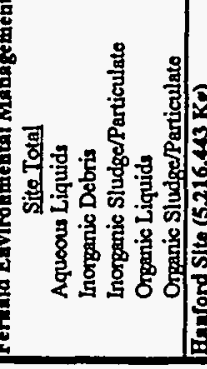 & 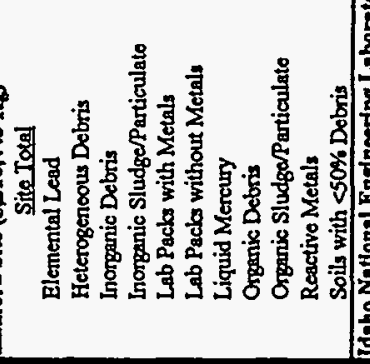 & 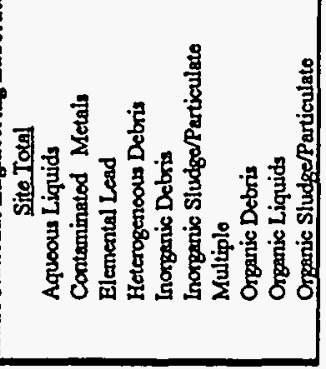 \\
\hline
\end{tabular}


Table 3.5. Elemental Composition of the Contact-Handled Low-Level Mired Wastes Located at Various DOE Sites Derived for the ITTS Study (continued)^

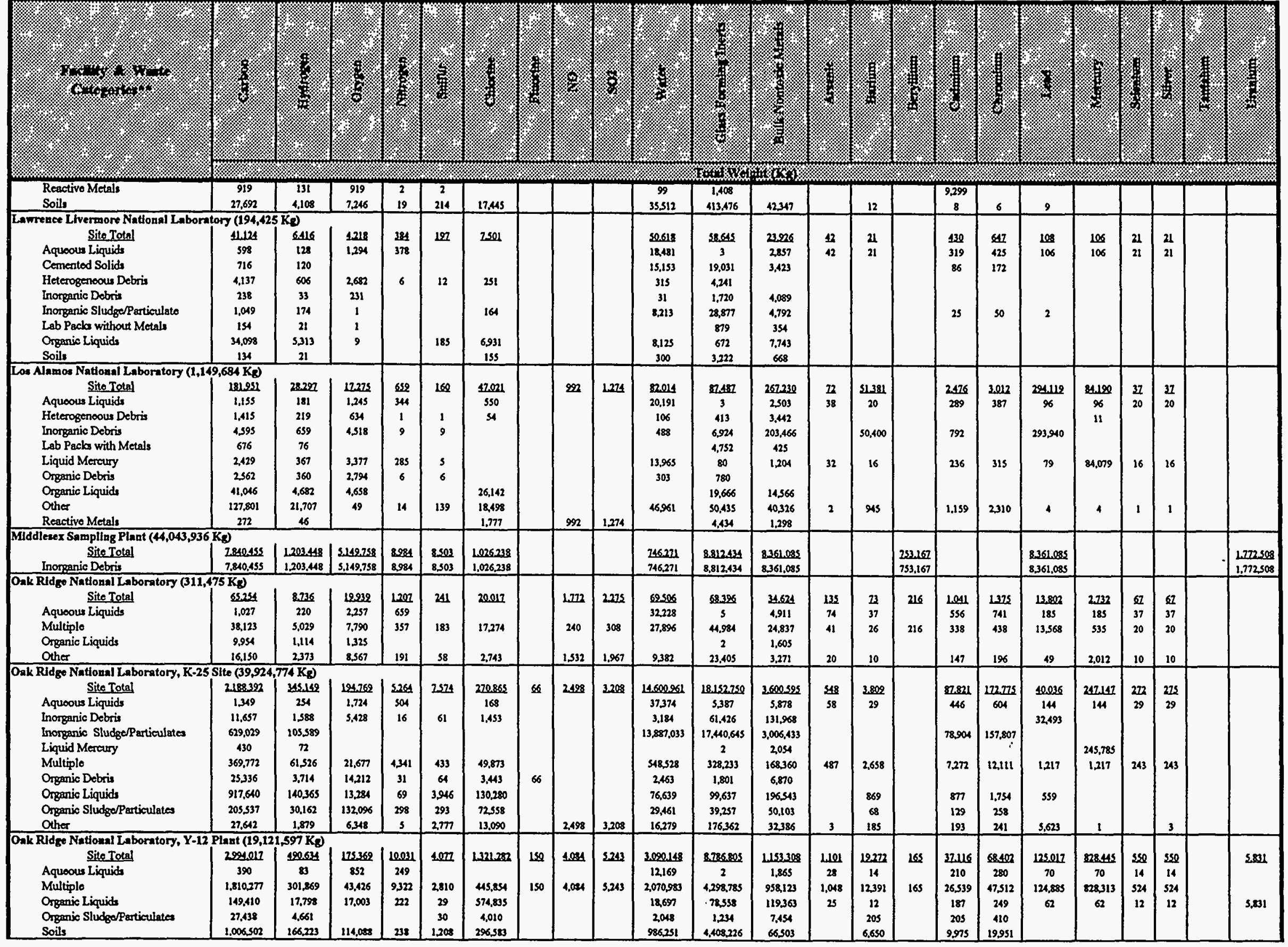


Table 3.5. Elemental Composition of the Contact-Handled Low-Level Mired Wastes Located at Various DOE Sites Derived for the ITTS Study (continued)*

\begin{tabular}{|c|c|c|c|c|c|c|c|c|c|c|c|c|c|c|c|c|c|c|c|c|c|c|c|}
\hline l? & ?: & $\frac{1}{8}$ & $\frac{1}{8}$ & 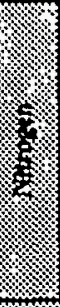 & 8 & $\sqrt[4]{8}$ & ?. & $\frac{3}{2}$ & $\begin{array}{l}4 \\
8 \\
8\end{array}$ & $\frac{\sqrt{3}}{4}$ & $\frac{1}{4}$ & i & ? & $\frac{8}{6}$ & 8 & 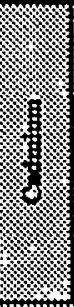 & $\sqrt{6}$ & . & \% & 8 & $\frac{1}{4}$ & 4 & $\sqrt[4]{\sqrt[4]{4}}$ \\
\hline (3) & & & & & & & & & & \$ & OSt & (KX) & \% & s. & \% & & $\ldots$ & & & & & & \\
\hline $\begin{array}{c}\text { Paduchih Garcous Difusion PlantC C } \\
\text { Sito Total }\end{array}$ & $\begin{array}{l}338 \mathrm{~KB} \\
\$ 6368\end{array}$ & & & 151 & 312 & 16923 & & 84 & $n$ & & & & & & 31 & & & & & 16 & & & 1791 \\
\hline $\begin{array}{l}\text { Aquocus Liquids } \\
\text { Betteries }\end{array}$ & $\begin{array}{l}180 \\
59 \\
62\end{array}$ & $\begin{array}{l}29 \\
11\end{array}$ & 38 & 28 & 19 & 28 & & 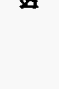 & & $\begin{array}{l}42,740 \\
60\end{array}$ & 1 & $\begin{array}{l}2285 \\
223 \\
131\end{array}$ & 3 & 2 & 1 & $\frac{2 x}{34}$ & 32 & $\begin{array}{l}1,104 \\
1,342\end{array}$ & 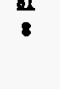 & 2 & $\frac{10}{2}$ & & 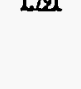 \\
\hline 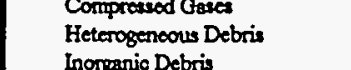 & $\begin{array}{l}62 \\
3.873 \\
457\end{array}$ & $\begin{array}{l}10 \\
58 \\
69\end{array}$ & 23,34 & 3 & 3 & 48 & & & & $\begin{array}{l}732 \\
2,110 \\
34\end{array}$ & $\begin{array}{l}10,430 \\
157\end{array}$ & $\begin{array}{l}1.1812 \\
2.145 \\
10190\end{array}$ & 13 & 6 & & $\boldsymbol{n}$ & 129 & 32 & 32 & 6 & 6 & & 1,146 \\
\hline $\begin{array}{l}\text { Inonganic Debris } \\
\text { Inorganic Sludge/Particulates }\end{array}$ & 2,170 & 271 & 239 & & 95 & 261 & & & & 年, & 13.068 & $\begin{array}{l}3,1,335 \\
353\end{array}$ & & 6 & & 39 & 74 & $s$ & & & & & 14s \\
\hline Lob Pacha with Metals & 7.753 & 1,253 & 1,197 & 6 & 9 & 229 & & & & 950 & 12,800 & 5,101 & & 39 & & 39 & 77 & 26 & & & & & \\
\hline $\begin{array}{l}\text { Multiple } \\
\text { Organic Debris }\end{array}$ & $\begin{array}{l}136 \\
7,898\end{array}$ & $\begin{array}{c}66 \\
1,189\end{array}$ & $\begin{array}{l}23 \\
2.821\end{array}$ & $?$ & 27 & ${ }_{94}^{114}$ & & 64 & 82 & $\begin{array}{l}3,133 \\
5,667\end{array}$ & $\begin{array}{l}7.097 \\
13,004\end{array}$ & $\begin{array}{l}1,464 \\
1,061\end{array}$ & 6 & 3 & & $\begin{array}{l}61 \\
27\end{array}$ & $\begin{array}{l}90 \\
\$ 4\end{array}$ & 16 & 16 & 3 & 3 & & \\
\hline $\begin{array}{l}\text { Orgennic Liquidr } \\
\text { Organic SludgefParticulateses }\end{array}$ & $\begin{array}{c}26.361 \\
1.535\end{array}$ & $\begin{array}{l}3,972 \\
17 n\end{array}$ & 435 & 2 & 127 & $\begin{array}{l}4,474 \\
7,220\end{array}$ & & & & 926 & $\begin{array}{c}1.680 \\
1\end{array}$ & $\begin{array}{l}4,887 \\
1,157\end{array}$ & & & & & & 17 & & & & & \\
\hline & 3584 & 798 & 2,780 & 93 & 29 & 761 & & & & 6.834 & 7.952 & 3,694 & 10 & 236 & 81 & 319 & 140 & 25 & 25 & $s$ & $s$ & & 190 \\
\hline Pantex Plant (77,776 Kह) & & & & & & & & & & & & & & & & & & & & & & & \\
\hline Aqueous Liquids & $\begin{array}{l}2028 \\
96\end{array}$ & $\begin{array}{l}2414 \\
19\end{array}$ & $\begin{array}{l}2.287 \\
135\end{array}$ & $\begin{array}{l}28 \\
45\end{array}$ & 22 & $\frac{2414}{3}$ & & & & $\frac{6.931}{2.828}$ & 12.329 & $\frac{12.894}{423}$ & $\frac{6}{3}$ & $\frac{1}{3}$ & & ${ }_{38}^{21}$ & $\begin{array}{l}29 \\
31\end{array}$ & $\frac{2309}{13}$ & 泣 & $\frac{3}{3}$ & 3 & & \\
\hline $\begin{array}{l}\text { Batteries } \\
\text { Heteresenous Debris }\end{array}$ & $\begin{array}{c}76 \\
1310\end{array}$ & $\begin{array}{l}15 \\
189\end{array}$ & os & 2 & ${ }_{3}^{42}$ & 81 & & & & 133 & 1,522 & 239 & & & & $?$ & 5 & 3.002 & 107 & & & & \\
\hline Inorganic Sludge/Particulates & 306 & 4 & 306 & $i$ & 1 & at & & & & 3,117 & $4,3,1$ & $\begin{array}{r}738 \\
4,672\end{array}$ & & & & is & 35 & 518 & & & & & \\
\hline $\begin{array}{l}\text { Multiple } \\
\text { Ontomic Liowids }\end{array}$ & 14,7m & 1,737 & 3,869 & 10 & 24 & 9,328 & & & & 670 & 6,175 & 6,116 & 1 & & & 4 & 6 & 3,772 & 1 & & & & \\
\hline 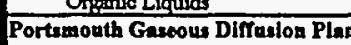 & $\frac{4,023}{327,198 \mathrm{~K}}$ & & & & & & & & & & & & & & & & & & & & & & \\
\hline $\begin{array}{l}\text { Site Total } \\
\end{array}$ & 187386 & 21,621 & 124508 & 1.076 & L.481 & 245.601 & & z4 & \$1 & 332.292 & 11085.506 & 522312 & 166 & ws & & 1.558 & & & 2.48 & $y$ & $\underline{3}$ & & 16474 \\
\hline $\begin{array}{l}\text { Aquoous Liquids } \\
\text { Batteriea }\end{array}$ & 5,229 & 62 & $m$ & 226 & 4 & 16,045 & & & & 31,980 & 2,439 & 6.469 & 25 & 13 & & 190 & 205 & 86 & 63 & 13 & 13 & & \\
\hline Compresered Orases & 258 & 37 & 230 & & 8 & 3 & & & & $\begin{array}{l}251 \\
25\end{array}$ & 332 & $\begin{array}{l}1787 \\
735\end{array}$ & & & & & & & & & & & \\
\hline Heterogeneous Debris & 78.284 & 10.959 & 50,698 & 106 & 24 & 10.871 & & н & 44 & 24.744 & 176.270 & 38:8S1 & 73 & 42 & & 360 & 754 & 183 & 193 & 37 & 37 & & \\
\hline Inorganic Debris & 5,258 & $m 4$ & 3,897 & 8 & 12 & 307 & & & & & 22.633 & & & & & & & 2.370 & 900 & & & & \\
\hline Inorganic Sludge/Particulates & 9,778 & 1,386 & 4,789 & 334 & 7 & 20 & & & & 83,424 & 88.307 & 20,537 & 38 & 19 & & 634 & 1,079 & 24 & r4 & 19 & 19 & & 16,474 \\
\hline $\begin{array}{l}\text { Leb Pocla with Metals } \\
\text { Liquid Mereary }\end{array}$ & 827 & 149 & 478 & 139 & & & & & & 1.359 & 19,934 & 2809 & 18 & 9 & & 136 & 181 & 49 & 43 & 9 & 9 & & \\
\hline $\begin{array}{l}\text { Lqquid Merenty } \\
\text { Multiplo }\end{array}$ & 321 & 43 & 117 & 2 & & 3 & & & & 225 & 197 & 220 & & & & 3 & 4 & 1 & $i$ & & & & \\
\hline nic Debris & 150.5 & 22,310 & 58,652 & 147 & 650 & 12.843 & & & & & 73,984 & 897 & & & & & & & & & & & \\
\hline & 106,508 & 15,307 & 4.325 & 109 & 420 & 16,344 & & & & 13986 & 876 & 19,784 & 12 & 6 & & 92 & 122 & 31 & 31 & 6 & 6 & & \\
\hline 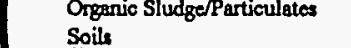 & $\begin{array}{c}1,220 \\
125.962\end{array}$ & $\begin{array}{c}713 \\
19219\end{array}$ & $\begin{array}{c}10 \\
303\end{array}$ & $i$ & $i$ & $\begin{array}{l}311 \\
188563\end{array}$ & & & & $\begin{array}{c}581 \\
365,201\end{array}$ & $\begin{array}{l}2,900 \\
3,200,634\end{array}$ & $\begin{array}{l}1,9,4 \\
393,006\end{array}$ & & 29 & & 29 & 58 & 32 & & & & & \\
\hline Paget Sound Naval Shipyard (66,33 & & & & & & & & & & & & & & & & & & & & & & & \\
\hline $\begin{array}{c}\text { Site. Tolal } \\
\text { Cementod Solids }\end{array}$ & $\frac{3840}{901}$ & $\begin{array}{l}\frac{29}{132} \\
148\end{array}$ & 2519 & 8 & 12 & 257 & & & & $\begin{array}{l}3.983 \\
3,706\end{array}$ & $\begin{array}{l}46493 \\
45,339\end{array}$ & $\begin{array}{l}5.898 \\
4,320\end{array}$ & & & & $\begin{array}{l}376 \\
124\end{array}$ & $\begin{array}{l}247 \\
207\end{array}$ & 252 & $\mathbf{A 1}$ & & & & \\
\hline $\begin{array}{l}\text { Helerogenenous Debris } \\
\text { Orgenic Debris }\end{array}$ & 1,215 & $\begin{array}{l}478 \\
167\end{array}$ & $\begin{array}{l}1.583 \\
936\end{array}$ & 3 & ${ }_{2}^{10}$ & 257 & & & & ${ }_{96}^{181}$ & $\begin{array}{l}399 \\
293\end{array}$ & $\begin{array}{c}963 \\
525\end{array}$ & & & & 252 & & 252 & 41 & & & & \\
\hline Rockg Fiats Plant (15,438,864 Kg) & & & & & & & & & & & & & & & & & & & & & & & \\
\hline $\begin{array}{c}\text { Site Tetal } \\
\text { Acurosus Livuids }\end{array}$ & 12372259 & 292.277 & $\frac{22,075}{508}$ & 526 & 2252 & 232,237 & & 42 & $\$$ & 20533 & 0.0201658 & 12431422 & $\frac{19}{m}$ & 2.538 & 27 & 212000 & 63.730 & $3624+42$ & 121 & 25 & 23 & $\mathbf{8}$ & 102345 \\
\hline $\begin{array}{l}\text { Aqueocis Lquads } \\
\text { Beryllium Dust }\end{array}$ & 32 & 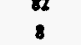 & 178 & & & & & & & $\begin{array}{l}9,65 \\
2\end{array}$ & 1 & $\begin{array}{l}1,2828 \\
189\end{array}$ & & & $n$ & & & & & & & & \\
\hline Cencented Solids & 4,025 & 624 & $2 m$ & 3 & 6 & 237 & & & & 7,668 & 93,740 & 91,287 & & 12 & & $\boldsymbol{u}$ & 48 & & & & & & \\
\hline atal Lead & $2 z_{2}$ & 120 & 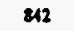 & 2 & 2 & & & & & 91 & 1,291 & & & & & & & 287,100 & & & & & \\
\hline Inorgenic Debris & 60386 & 8.34 & 38,677 & ${ }^{138}$ & 114 & 16,773 & & & & 11,673 & 72,399 & 27.683 & 6 & & & 48 & 62 & 82230 & 15 & 3 & 3 & 93 & \\
\hline 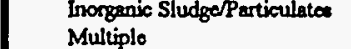 & $\begin{array}{l}1,58.117 \\
3.061\end{array}$ & 264230 & $\begin{array}{l}34,282 \\
1,206\end{array}$ & 13 & ${ }_{4}^{1,685}$ & 206,059 & & 47 & 60 & 3359291 & $\begin{array}{l}10.010,453 \\
4,423\end{array}$ & 2.2027.88 & & 9,610 & & 3ises & 6.161 & 6 & & & & & 109,45 \\
\hline Organic Liguids & 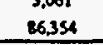 & $\begin{array}{r}23,197 \\
\end{array}$ & 1.064 & 194 & 40 & $\begin{array}{l}13,281 \\
\end{array}$ & & & $\infty$ & 12.166 & 200383 & $\begin{array}{l}2,487 \\
18,273\end{array}$ & 22 & il & & $\begin{array}{l}26 \\
163 \\
\end{array}$ & 218 & s4 & s4 & iI & u & & \\
\hline
\end{tabular}


Table 3.5. Elemental Composition of the Contact-Handled Low-Level Mixed Wastes Located at Various DOE Sites Derived for the ITTS Study (continued)*

\begin{tabular}{|c|c|c|c|c|c|c|c|c|c|c|c|c|c|c|c|c|c|c|c|c|c|c|c|}
\hline 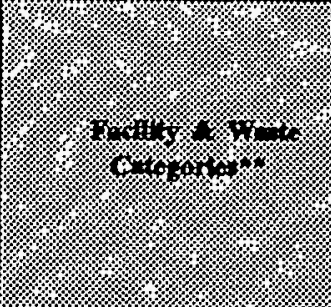 & ry & $\frac{1}{4}$ & 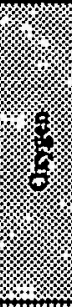 & $\frac{\gamma}{8}$ & 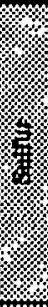 & \%: & 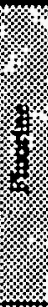 & \%x & $\frac{8}{8}$ & 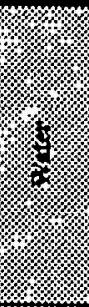 & $\frac{1}{4}$ & $\frac{1}{4}$ & 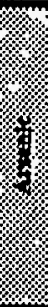 & \% & 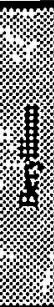 & \%: & 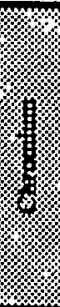 & 84 & 㬗 & 梦 & 8 & $\frac{1}{4}$ & 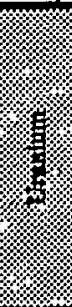 \\
\hline & k & \% & & \% & $\%$ & & $\%$ & & & & W & (1) & & & & & & & \% & & & & \\
\hline Sandia Natiounal Laboratory $(9,07$ & & & & & & & & & & & & & & & & & & & & & & & \\
\hline Other Site Total & $\begin{array}{l}1.821 \\
1.891 \\
\end{array}$ & $\begin{array}{l}223 \\
293 \\
\end{array}$ & $\begin{array}{l}769 \\
769 \\
\end{array}$ & $\begin{array}{l}2 \\
2 \\
\end{array}$ & $\begin{array}{l}2 \\
2 \\
\end{array}$ & $\begin{array}{l}31 \\
31\end{array}$ & & & & $\begin{array}{l}156 \\
156\end{array}$ & $\frac{537}{537}$ & $\frac{\$ 330}{3,330}$ & & & & & & $\frac{57}{57}$ & & & & & 8 \\
\hline Savaunab River Site $(3,505,593)$ & & & & & & & & & & & & & & & & & & & & & & & \\
\hline Site Total & 425,731 & 63.195 & 212051 & 72147 & 514 & 2881 & & & & 1374867 & 827276 & $\frac{302098}{1020}$ & 157 & 379 & & 2137 & 14.1271 & 179.808 & 1932 & 379 & 372 & & \\
\hline Aquoous Liquids & 26,911 & 4,696 & 23,073 & 6.757 & & 2.993 & & & & 768,172 & 146 & 109,660 & 757 & 379 & & 3,680 & 7,573 & 1,993 & 1.893 & 379 & 379 & & \\
\hline Elemental Lead & 11,40 & 1.733 & 7,236 & 16 & 142 & 809 & & & & 0.179 & 14,659 & 10,009 & & & & 20 & 1 & 177,751 & & & & & \\
\hline Inonganic Debris & 4,152 & 296 & 2,087 & 1 & 4 & 14 & & & & 1.921 & 4,423 & 2,314 & & & & 138 & & 156 & 39 & & & & \\
\hline Inorganic Sludge/Particulates & 28,871 & 4,846 & & & & & & & & 369,100 & 714,744 & 137,990 & & & & 3,234 & 6,467 & & & & & & \\
\hline Organic Debris & 289,922 & 44.229 & 176,651 & 370 & 353 & 1,009 & & & & 32,173 & 139.371 & 30384 & & & & 65 & 130 & & & & & & \\
\hline $\begin{array}{l}\text { Organic Liquids } \\
\text { Soils }\end{array}$ & $\begin{array}{c}63,805 \\
632 \\
\end{array}$ & $\begin{array}{c}7.298 \\
97\end{array}$ & 8,004 & & 13 & $\begin{array}{l}2,196 \\
860 \\
\end{array}$ & & & & $\begin{array}{l}655 \\
1,665 \\
\end{array}$ & $\begin{array}{r}6,060 \\
17,873 \\
\end{array}$ & $\begin{array}{l}12560 \\
2.078\end{array}$ & & & & & & & & & & & \\
\hline Weldou Spring Sile $(64,546 \mathrm{Kg})$ & & & & & & & & & & & & & & & & & & & & & & & \\
\hline Site Total & 27970 & $\frac{3.18}{59}$ & 3,649 & 15 & 24 & 2.365 & & 233 & 826 & 8.261 & $\$ 167$ & 8.546 & 2 & 2 & & 18 & 21 & 3.045 & 1 & 1 & 1 & & \\
\hline $\begin{array}{l}\text { Aquoous Liquids } \\
\text { Batueries }\end{array}$ & 394 & 59 & 18 & 3 & 23 & 70 & & & & 8.633 & 1 & 1,440 & 1 & & & 4 & 6 & 1 & 1 & & & & \\
\hline $\begin{array}{l}\text { Baucres } \\
\text { Elemental Lead }\end{array}$ & 30 & 5 & 47 & & 23 & & & & & 74 & & 510 & & & & 4 & & 1,657 & & & & & \\
\hline Inorganic Sludga/Particulates & 247 & 41 & & & & 1,152 & & 733 & 836 & & 30039 & 142 & & & & & & 1,370 & & & & & \\
\hline Lab Paclo with Metals & 105 & 18 & 33 & 10 & & & & & & 94 & 1,380 & 425 & 1 & 1 & & 9 & 13 & 3 & 3 & 1 & 1 & & \\
\hline Multiple & 39 & 10 & & & & 1.080 & & & & 1 & 679 & 237 & & & & & & & & & & & \\
\hline Organic Liquids & 27.014 & 3.041 & 3.551 & & 1 & 63 & & & & 159 & 68 & 4,612 & & 1 & & 1 & 2 & 14 & & & & & \\
\hline
\end{tabular}


Table 3.6. Elemental Composition of the DOE Complex Contact-Handled Low-Level Mixed Wastes Derived for the ITTS Study*

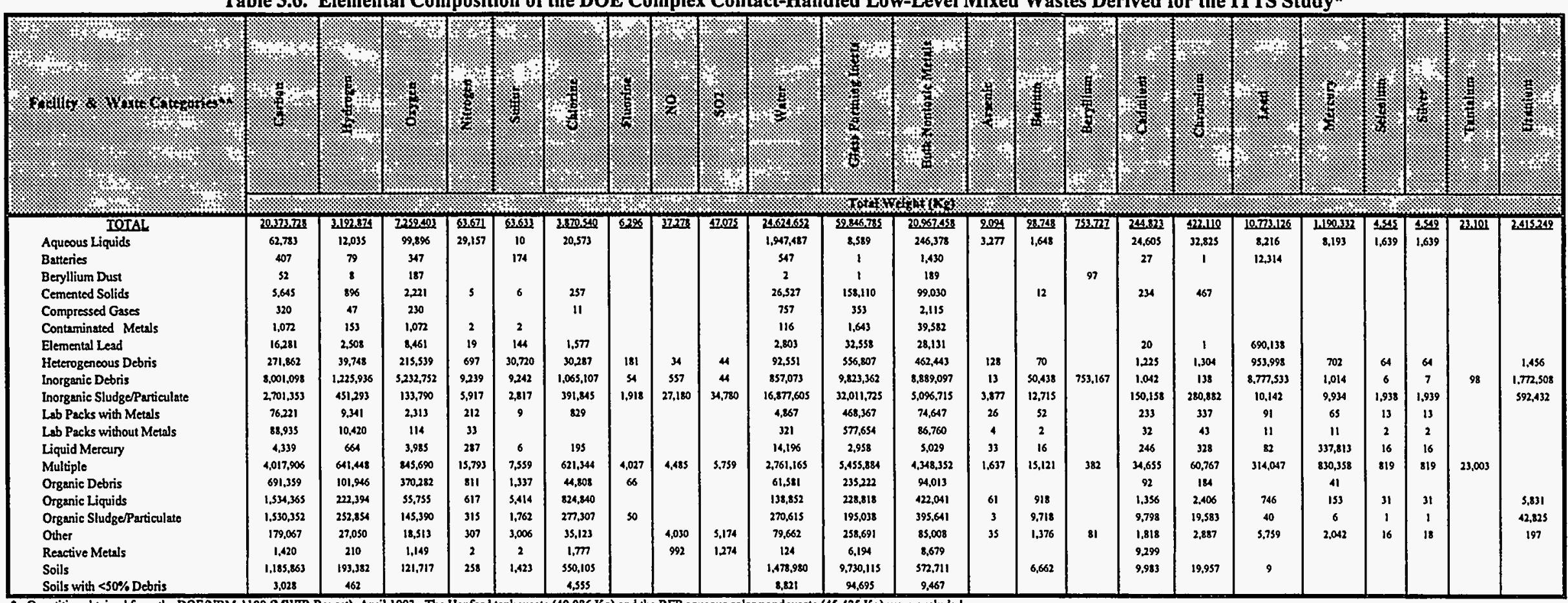

Quantities obtained from the DOENBM-1100 (MWIR Report), April 1993. The Hanford tank waste ( $\left(40,086 \mathrm{~K}_{8}\right.$ ) and the RFP equeous solar pond waste (45,425 Kg) were excluded.

- Warte Cartegries were obrained from the DOENBM-1100 (MWTR Report), April 1993. 



\section{Figure 3.1. Physical Matrix Distribution for DOE Complex Derived for the ITTS Study*}

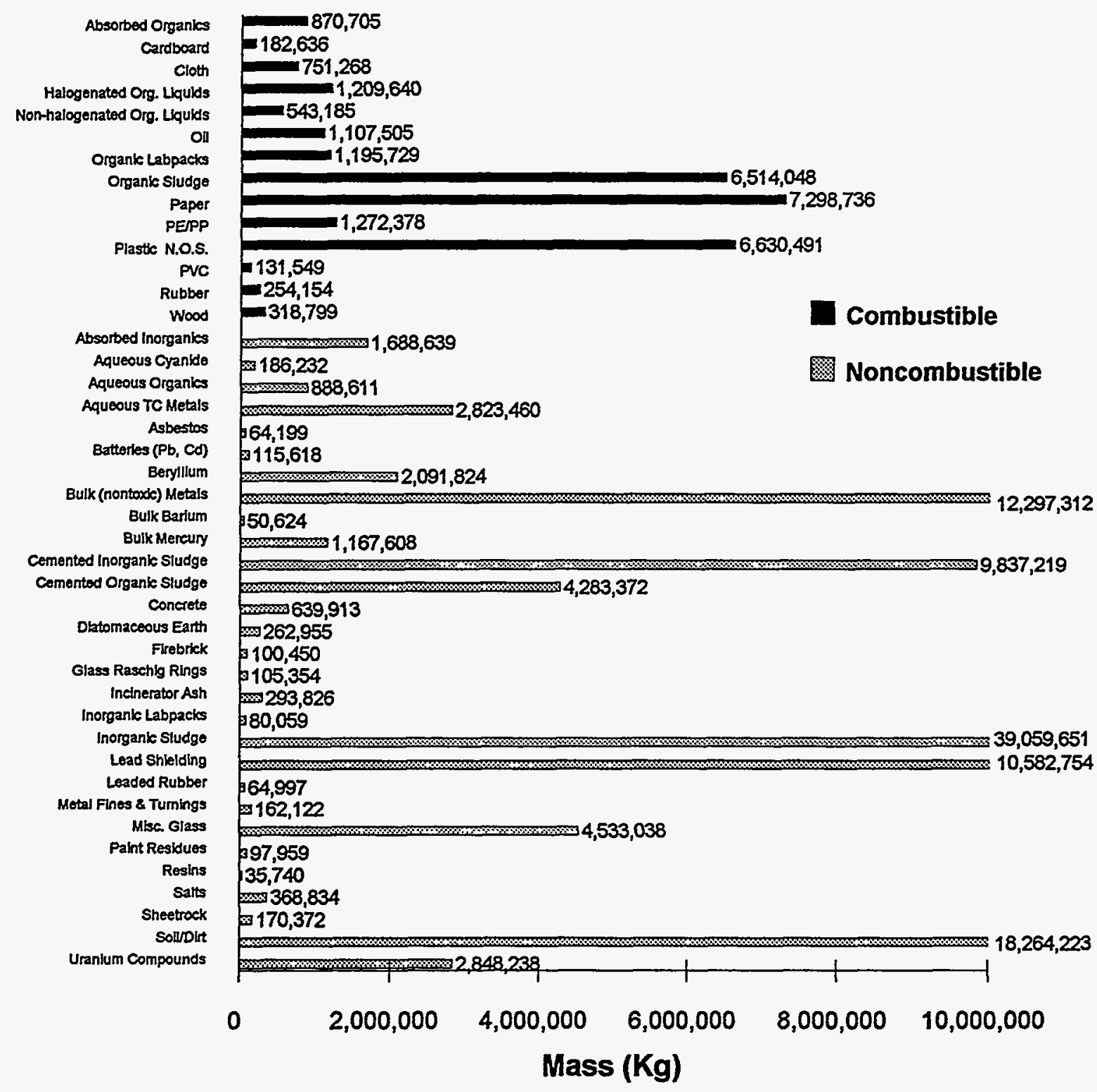

* Does not include mass of containers.

Physical Matrices not included: Ta, Flooring Mat., Ceramics, Cemented Org, Bulk Cd, Asphalt, TFE, Graphite due to amounts $<30,000 \mathrm{~kg}$. Information obtained from the DOE/NBM-1100 Apr. 1993. 


\section{Figure 3.2. Physical Matrix Distribution for DOE Complex - Derived for the ITTS Study*}

\begin{tabular}{|c|c|c|c|}
\hline$\square$ Absorbed Inorganics & Aqueous Liquids & Beryillum & Cemented Inorganic Sludge \\
\hline Cemented Organic Sludge & 굴 Inorganle Sludge & 曹 Lead Shielding & Misc. Glass \\
\hline Other & ஜ Organlc Sludge & 血 oll & $\mathbb{N}$ Paper \\
\hline 寻 Plastlc N.O.s. & 䍗 Soil/Dirt & IIII Bulk (nontoxic) Metals & Uranlum Compounds \\
\hline
\end{tabular}

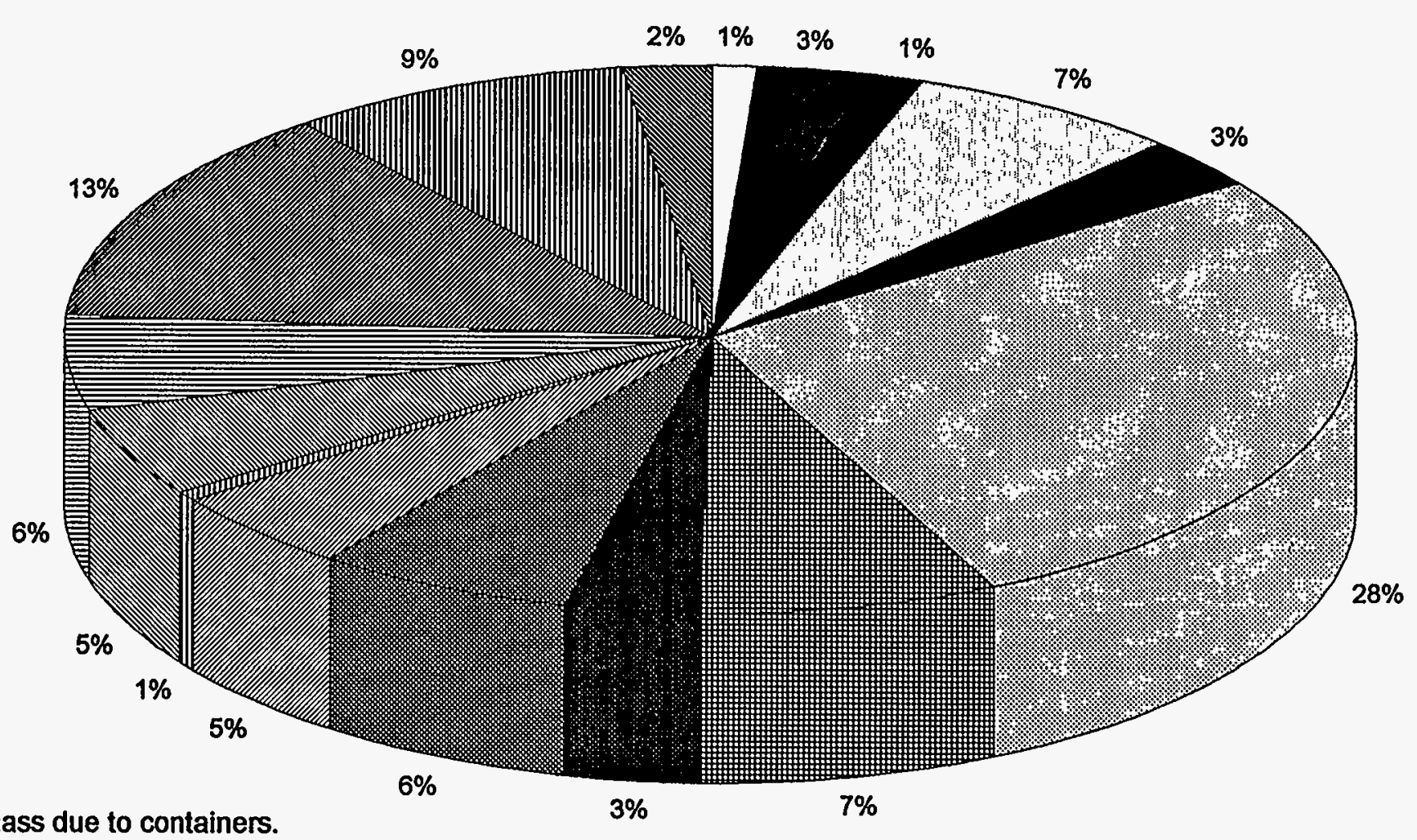

* Does not include mass due to containers.

"Other" consists of the remaining physical matrices.

Information obtained from the DOE/NBM-1100 (MWIR Report), April 1993. 


\section{Figure 3.3. Waste Distribution for the DOE Complex Including Containers Derived for the ITTS Study}

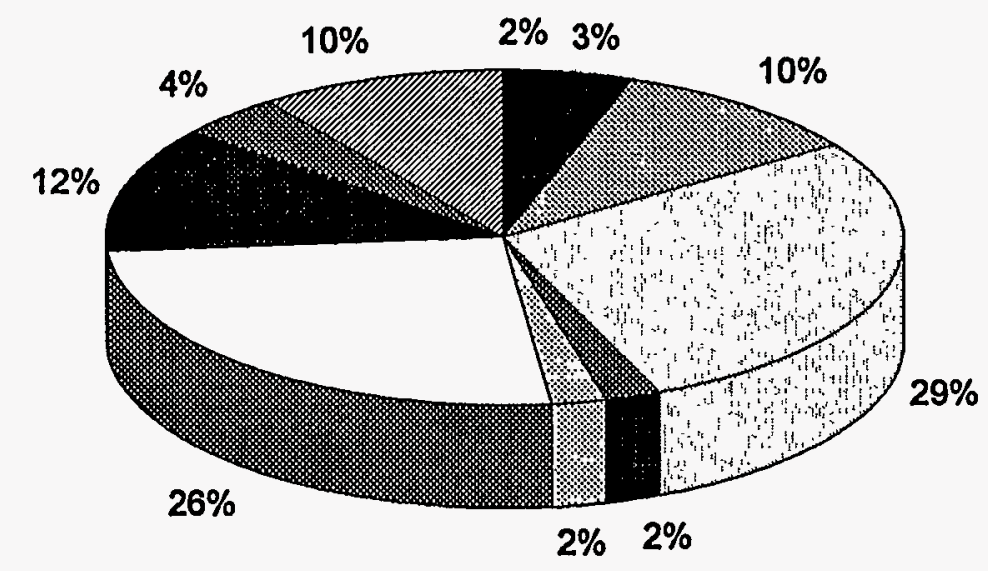

\begin{tabular}{|c|c|c|c|}
\hline $\begin{array}{l}\text { Fernald } \\
\text { Environmental } \\
\text { Management Project }\end{array}$ & Hanford Site & $\begin{array}{l}\text { Idaho National } \\
\text { Engineering } \\
\text { Laboratory }\end{array}$ & $\begin{array}{l}\text { Middlesex Sampling } \\
\text { Plant }\end{array}$ \\
\hline Other & Savannah River Site & $\begin{array}{l}\square \text { Oak Ridge National } \\
\text { Laboratory, K-25 Site }\end{array}$ & $\begin{array}{l}\text { Oak Ridge National } \\
\text { Laboratory, } Y-12 \\
\text { Plant }\end{array}$ \\
\hline
\end{tabular}




\section{Figure 3.4. Waste Distribution for the DOE Complex Excluding Containers Derived for the ITTS Study}

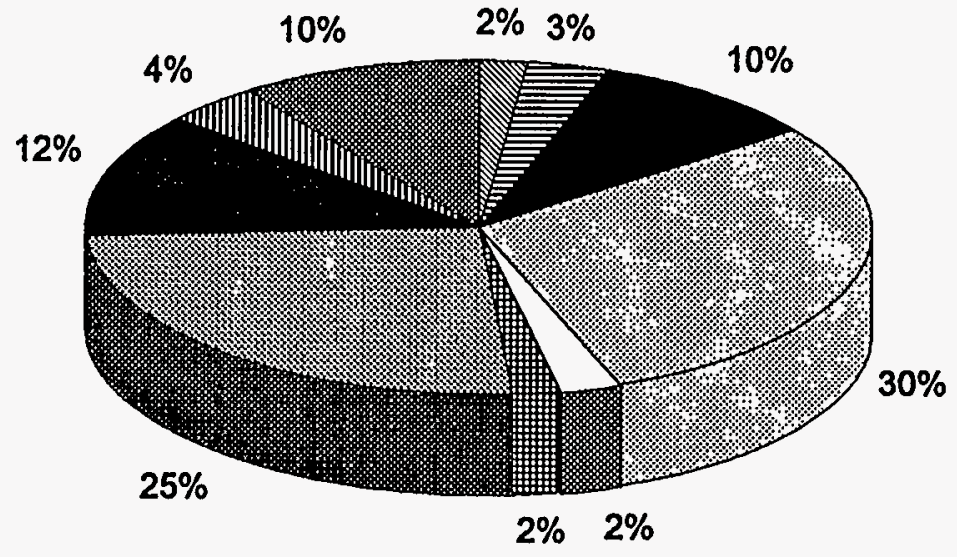
$\mathbb{N}$ Fernald
Environmental
Management Project

$\square$ other

目 Hanford Site

Idaho National

Engineering

Middlesex Sampling

Laboratory

Savannah River Site

Oak Ridge National Laboratory, K-25 Site

Plant

Oak Ridge National

Laboratory, Y-12

Plant

IIII Portsmouth Gaseous Rocky Flats Plant

Diffusion Plant 


\section{Figure 3.5. Combustible vs Noncombustible for DOE Complex Including Containers Derived for the ITTS Study (TOTAL=156,292,790 Kg)}

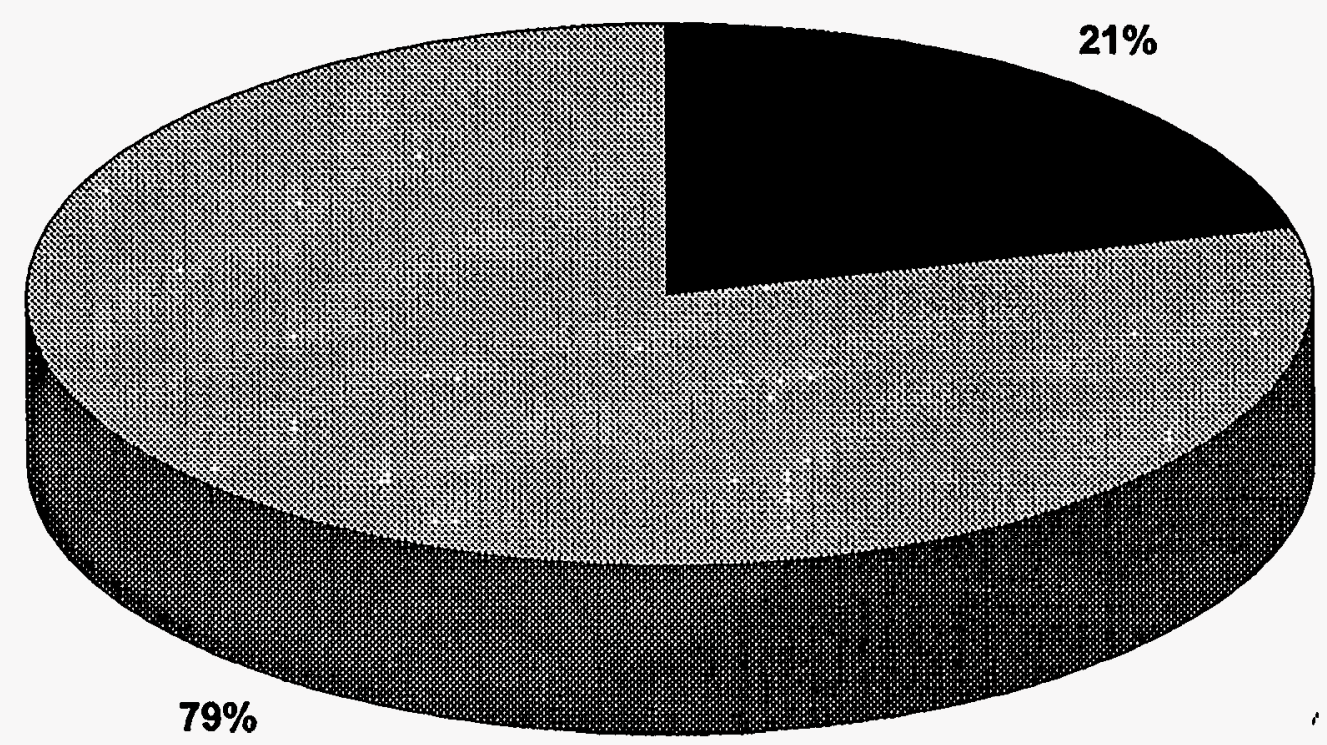

Combustible Noncombustible

Information obtained from the DOE/NBM-1100 (MWIR), April 1993.

Combustible portion of DOE wastes (w/o containers) $=28,303,176 \mathrm{Kg}$

Combustible portion of drums: $10,055,195 \times 19.7 \%$ (PE liner) $=1,980,873 \mathrm{Kg}$; boxes: $4,677,120 \times 60 \%=2,806,272 \mathrm{Kg}$ 


\section{Figure 3.6. Combustible vs Noncombustible for DOE Complex Excluding Containers Derived for the ITTS Study (TOTAL=141,560,474 Kg)}

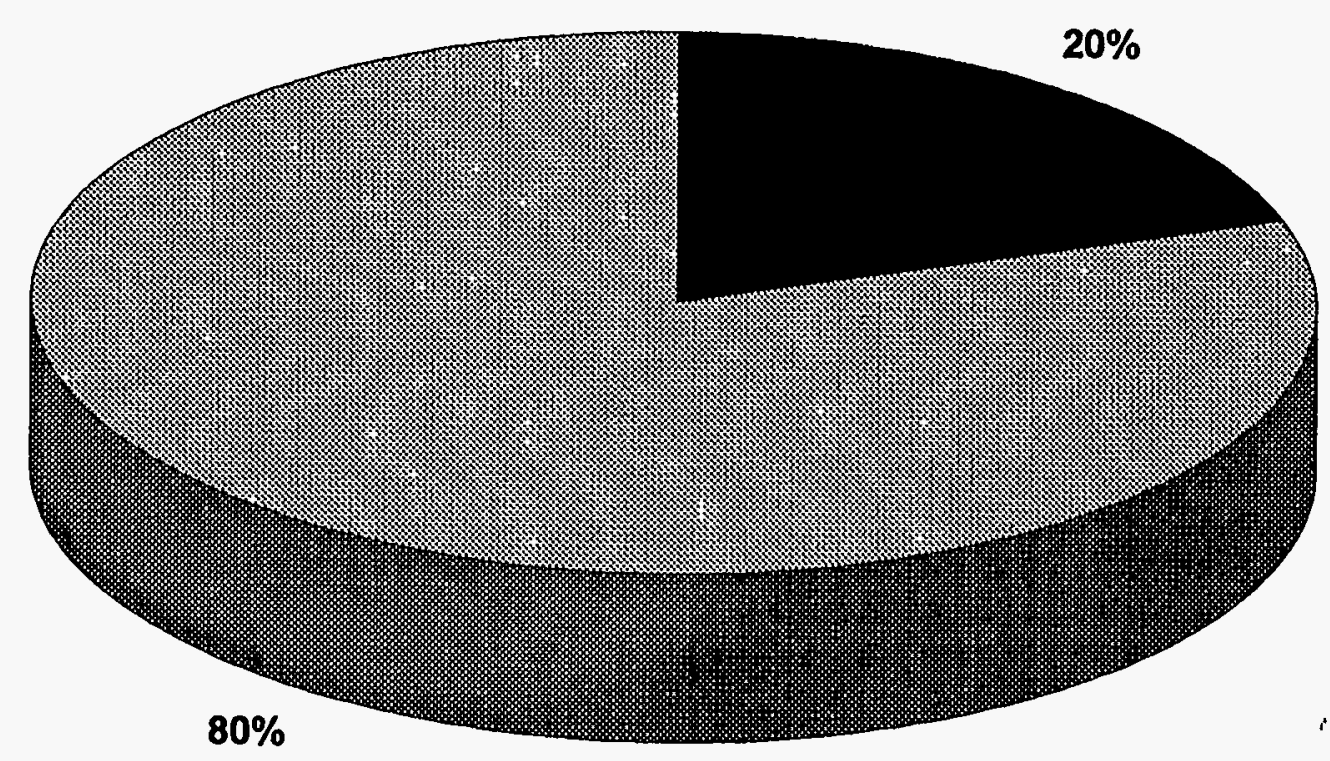

Combustible Noncombustible 


\section{Figure 3.7. Combustible Physical Matrix Distribution for the DOE Complex Derived for the ITTS Study (Combustibles=28,303,176 Kg)*}

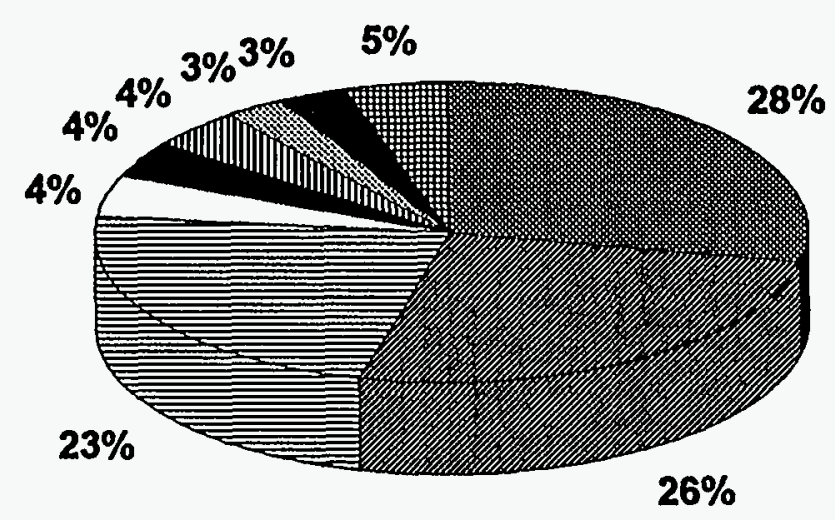

\begin{tabular}{|c|c|c|}
\hline Plastic N.O.S. & Oaper & Organic Sludge \\
\hline$\square$ Organic & Oil & $\begin{array}{l}\text { 箵 Halogenated Org. } \\
\text { Liquids }\end{array}$ \\
\hline Cloth & $\begin{array}{c}\text { Absorbed } \\
\text { Organics }\end{array}$ & 典 Other \\
\hline
\end{tabular}

" Does not include mass due to containers.

"Other" consists of Wood Products, Rubber, Non-halogenated Org. Liquids, Cloth, and Graphite.

Information obtained from the DOE/NBM-1100 (MWIR Report), April 1993. 


\section{Figure 3.8. Noncombustible Physical Matrix Distribution for the DOE Complex Derived for the ITTS Study (Noncombustibles $=113,257,298 \mathrm{Kg})^{*}$}

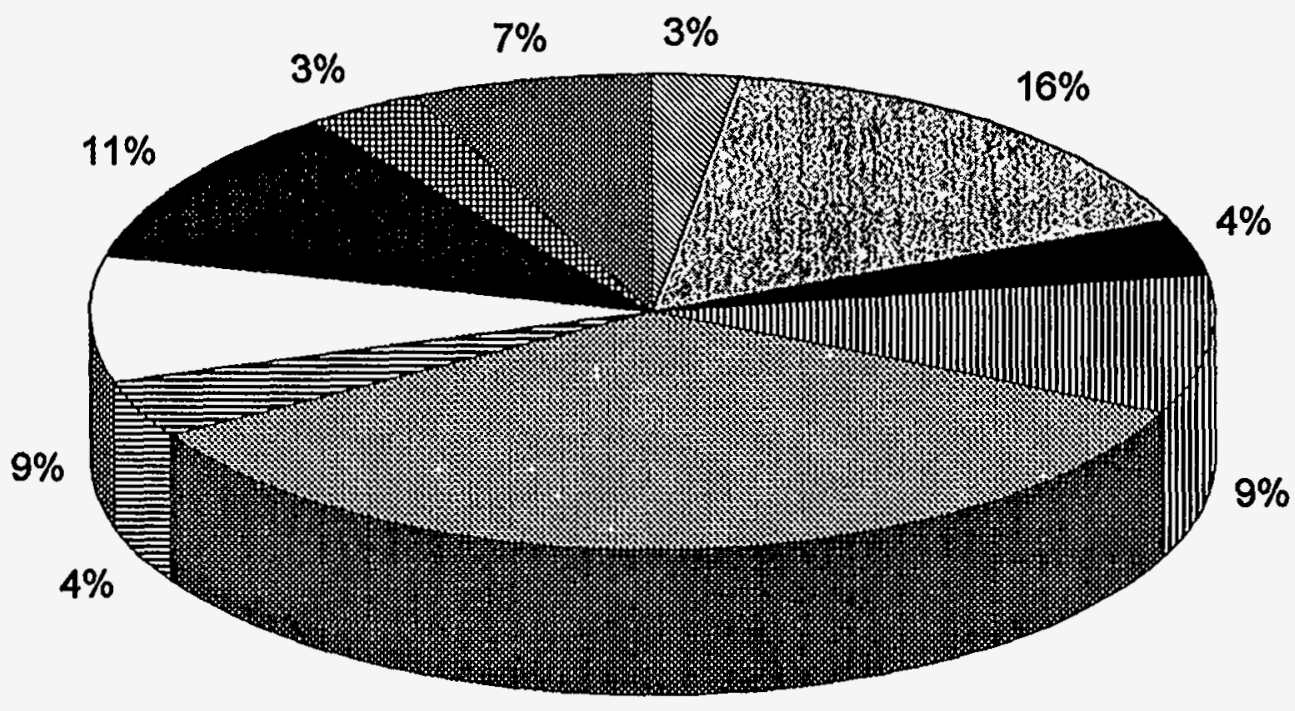

$34 \%$
Uranium Compounds

图 Soil/Dirt

Misc. Glass

IIIII Lead Shielding

Inorganic Sludge

冒 Cemented Organic Sludge

$\square$ Cemented Inorganic Sludge

Bulk (nontoxic) Metals

㻃 Aqueous Liquids

Other

"Other" consists of Sheetrock, Salts, Resins, Paint Residues, Metal Finings, Leaded Rubber, Inorganic Labpacks, Concrete, Bulk Mercury and Barium, Absorbed Inorganics, Beryllium, Batteries, and Asbestos.

"Aqueous Liquids" consists of Aqueous TC Metals, Aqueous Cyanide, and Aqueous Organics.

* Does not include mass due to containers.

Information obtained from the DOE/NBM-1100 (MWIR Report), April 1993. 


\section{Figure 3.9. Physical Matrix Distribution for Argonne National Laboratory--East Derived for the ITTS Study*}

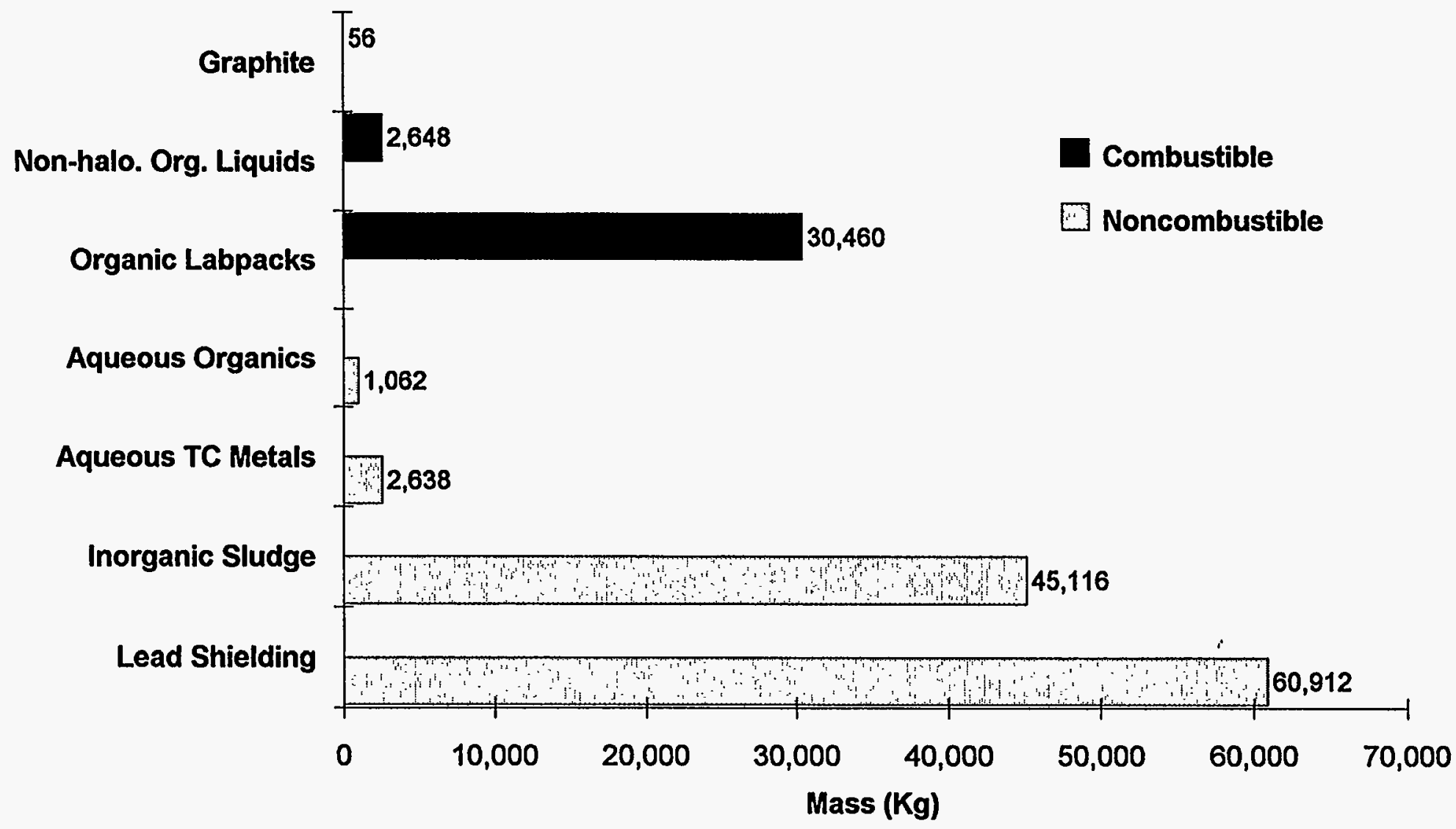

* Does not include mass due to containers.

Information obtained from the DOE/NBM-1100 (MWIR Report), April 1993. 


\section{Figure 3.10. Combustible vs Noncombustible for Argonne National Laboratory--East Derived for the ITTS Study (TOTAL=142,892 Kg)*}

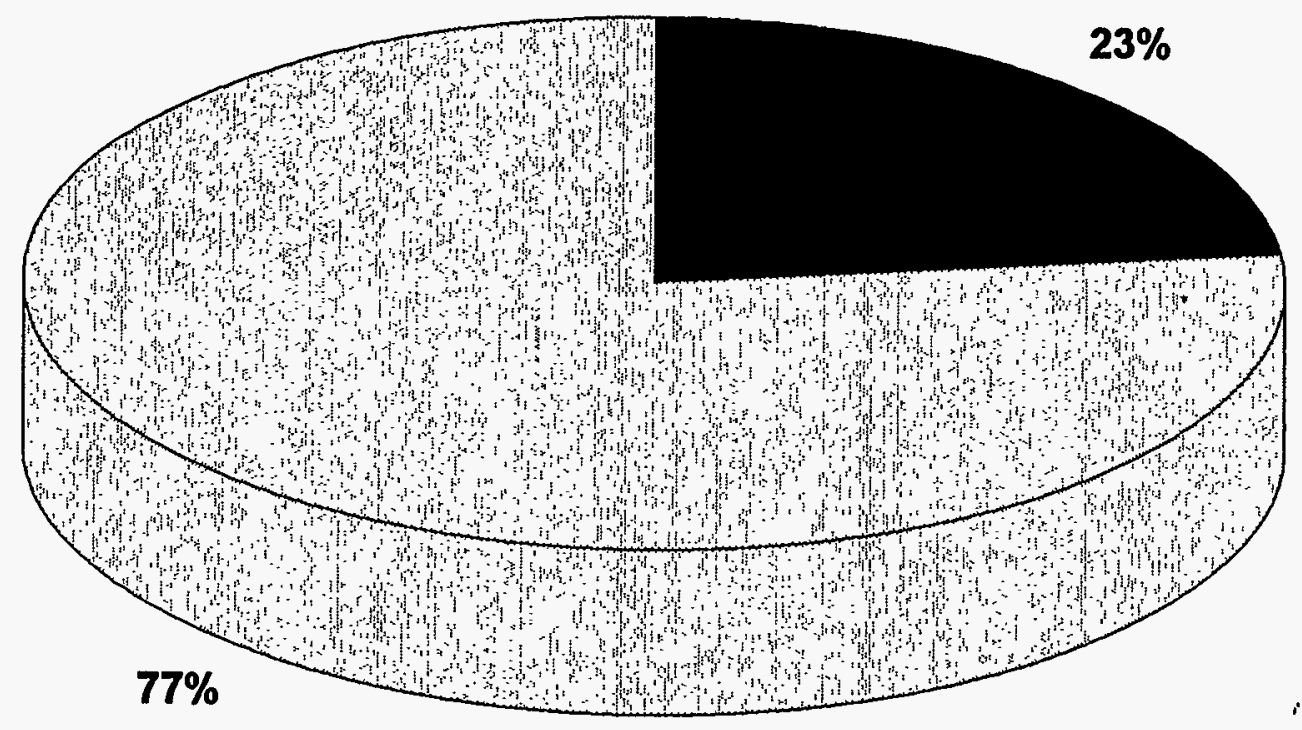

Combustible Noncombustible 


\section{Figure 3.11. Combustible Physical Matrix Distribution for Argonne National Laboratory--East Derived for the ITTS Study (Combustibles=33,164 Kg)*}

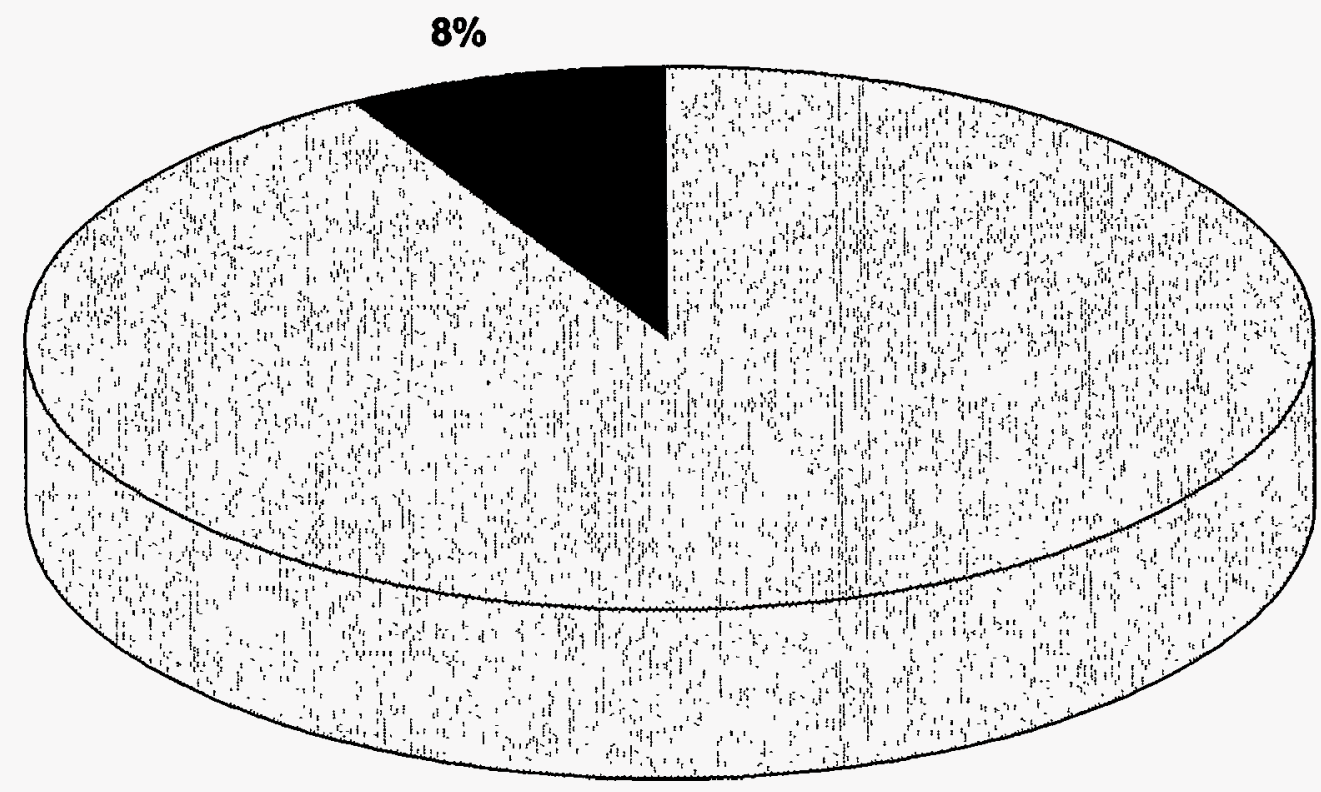

$92 \%$

[.] Organic Labpacks

Non-halogenated Org. Liquids

* Does not include mass due to containers.

Information obtained from the DOE/NBM-1100 (MWIR Report), April 1993. 


\section{Figure 3.12. Noncombustible Physical Matrix Distribution for Agronne National Laboratory--East Derived for the ITTS Study (Noncombustibles=109,728 Kg)*}

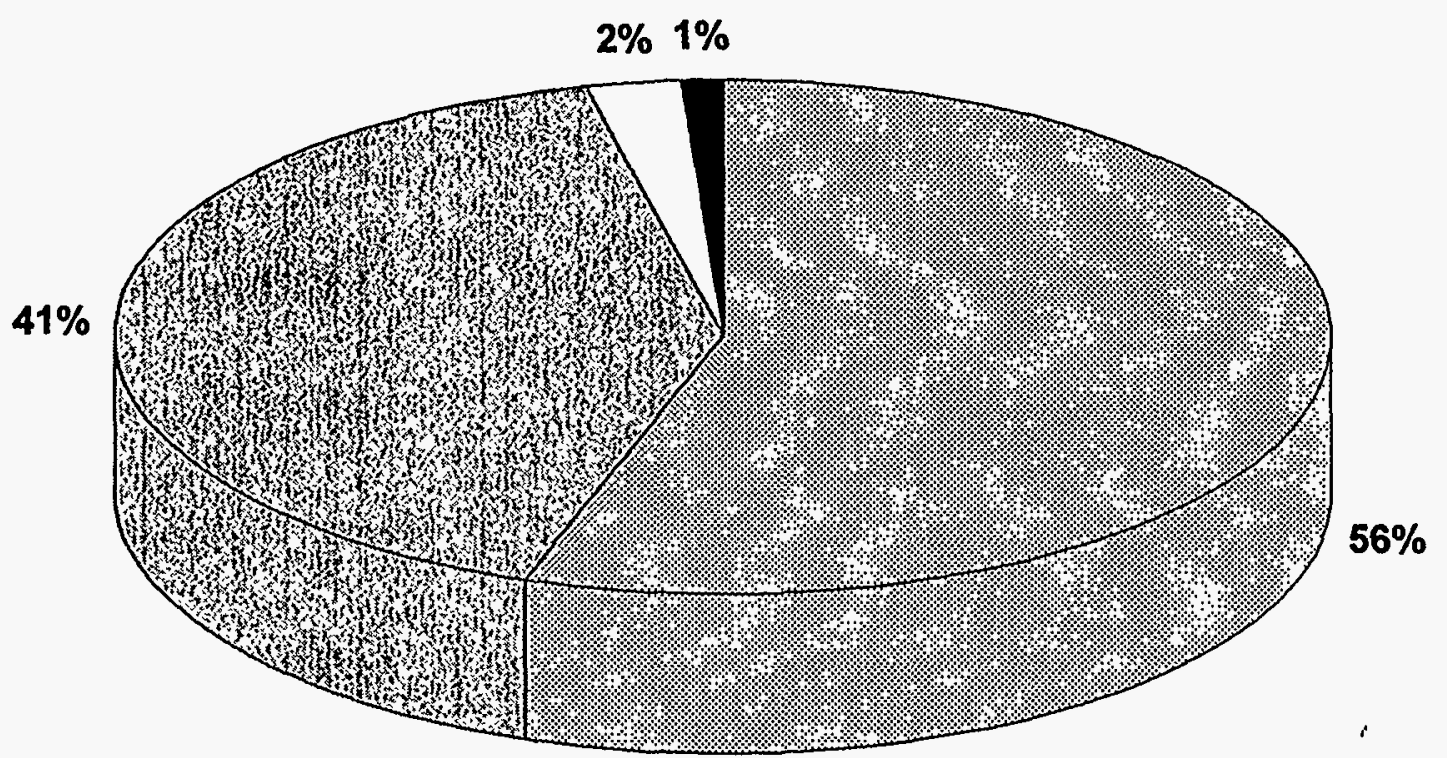

阎 Lead Shielding

션 Inorganic Sludge

$\square$ Aqueous TC Metals

Aqueous Organics

* Does not include mass due to containers.

Information obtained from the DOE/NBM-1100 (MWIR Report), April 1993. 


\section{Figure 3.13. Radiological Distribution for Argonne National Laboratory--East Derived for the ITTS Study}

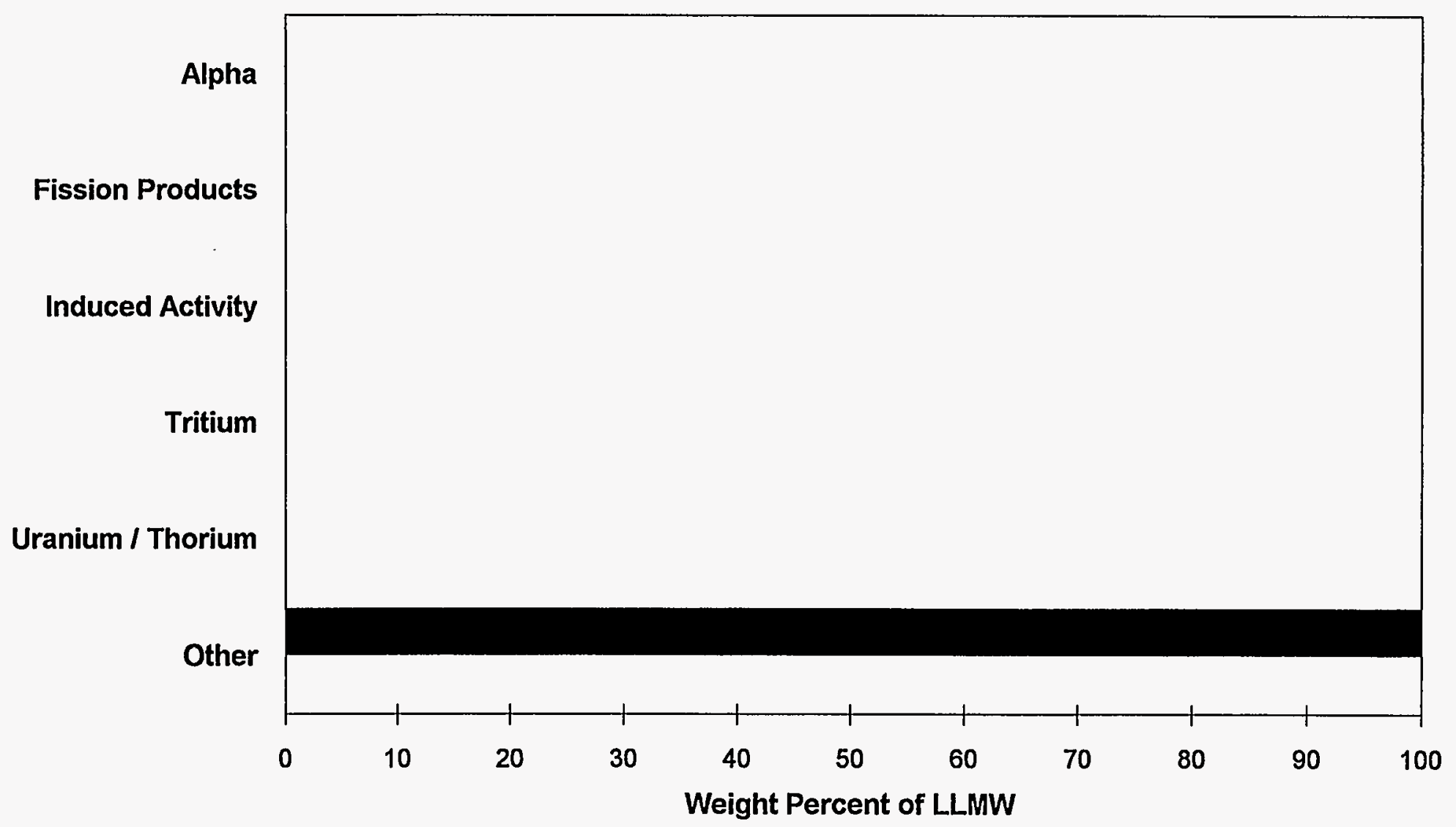




\section{Figure 3.14. Physical Matrix Distribution for Brookhaven National Laboratory Derived for the ITTS Study*}

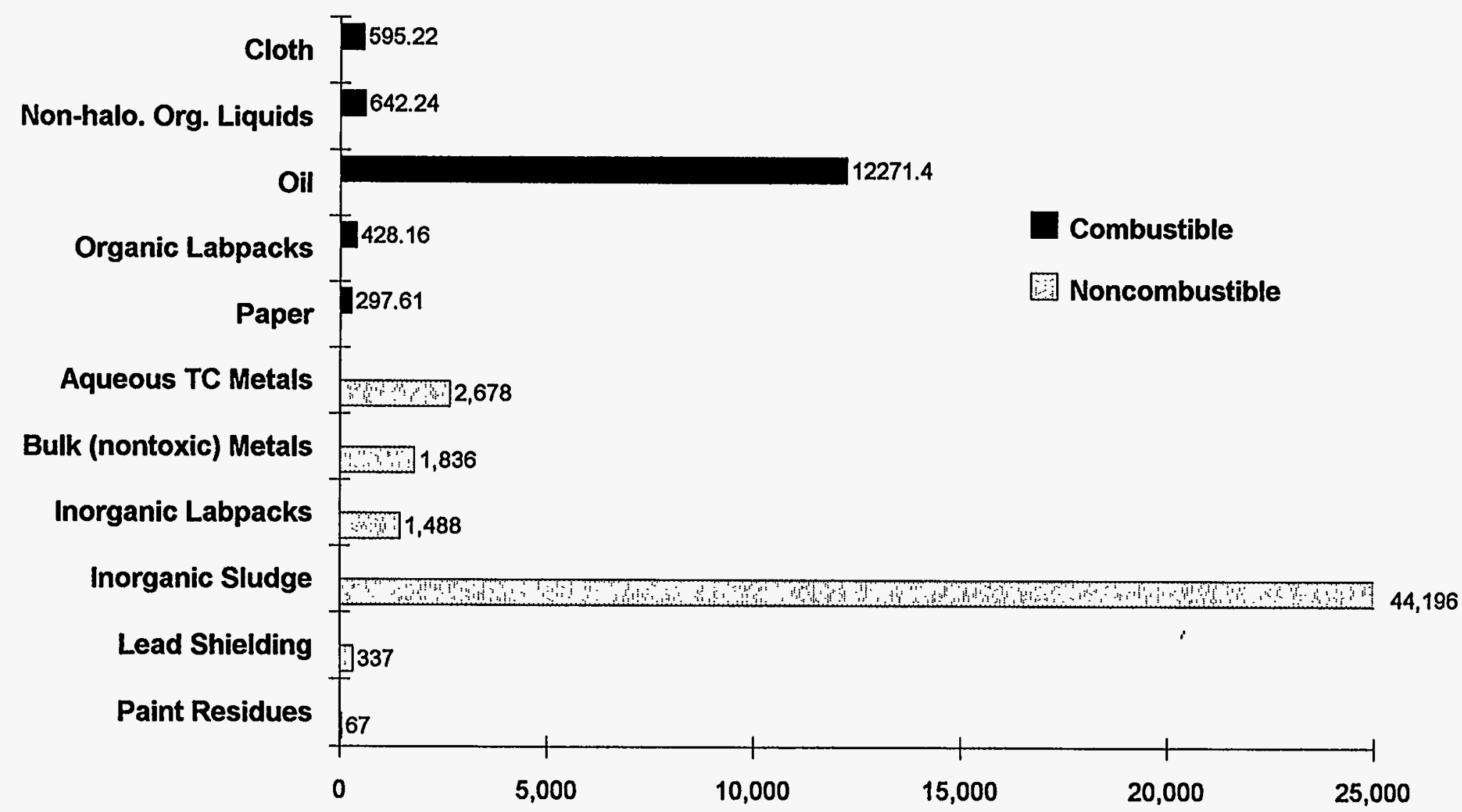

* Does not include mass due to containers.

Information obtained from the DOE/NBM-1100 (MWIR Report), April 1993. 


\section{Figure 3.15. Combustible vs Noncombustible for Brookhaven National Laboratory Derived for the ITTS Study (TOTAL=64,837 Kg)*}

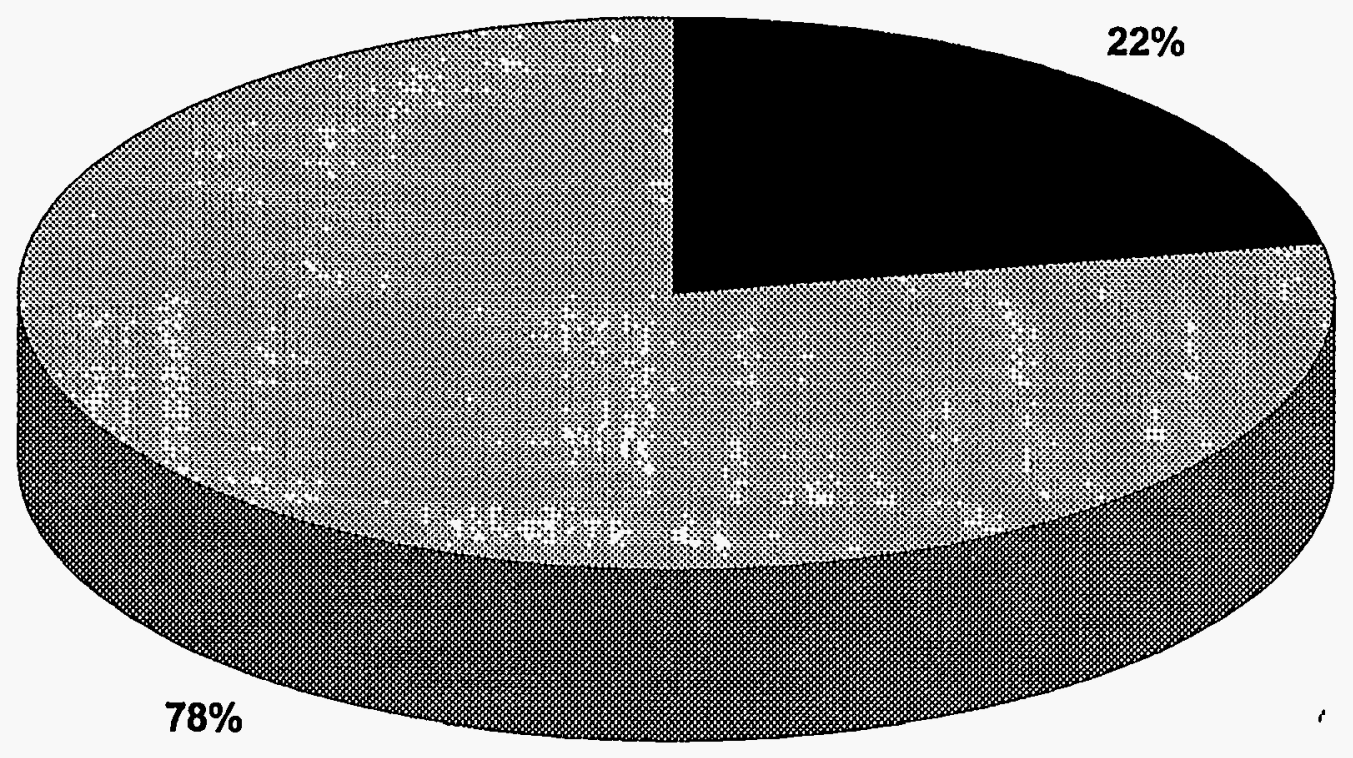

Combustible Noncombustible 


\section{Figure 3.16. Combustible Physical Matrix Distribution for Brookhaven National Laboratory Derived for the ITTS Study (Combustibles $=14,235 \mathrm{Kg})^{*}$}

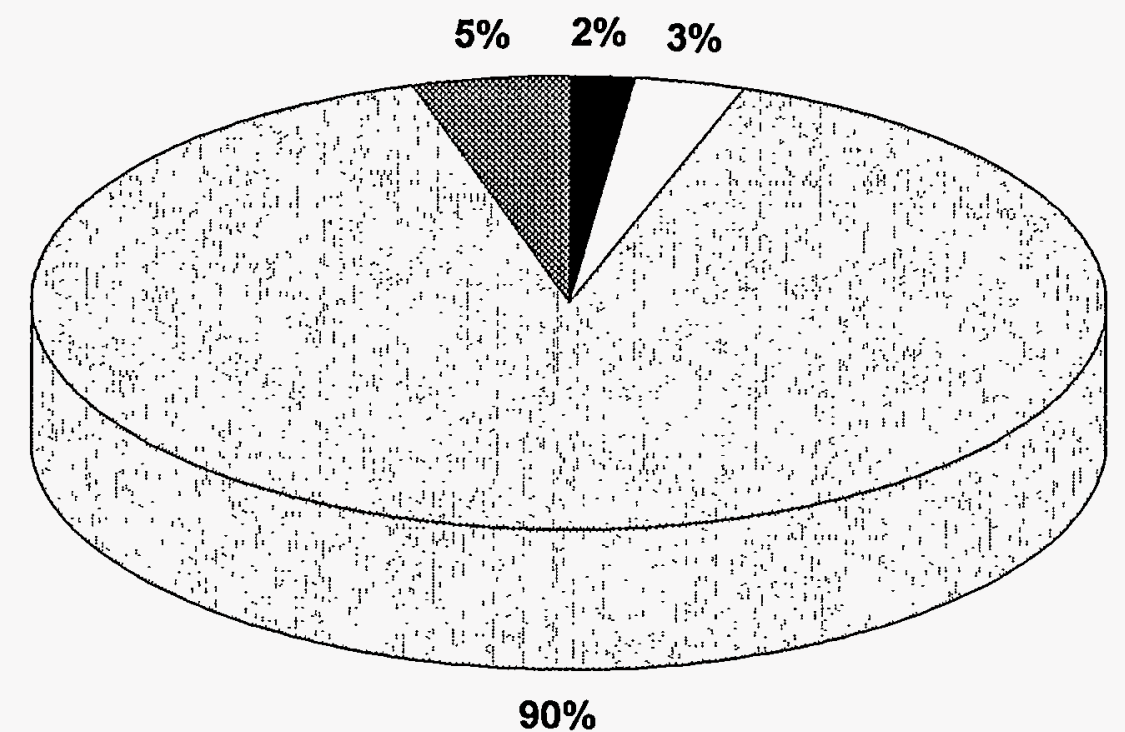

Paper

$\square$ Organic Labpacks $\square$ Oil

Non-halo. Org. Liquids 


\section{Figure 3.17. Noncombustible Physical Matrix Distribution for Brookhaven National Laboratory Derived for the ITTS Study (Noncombustibles=50,602 Kg) ${ }^{*}$}

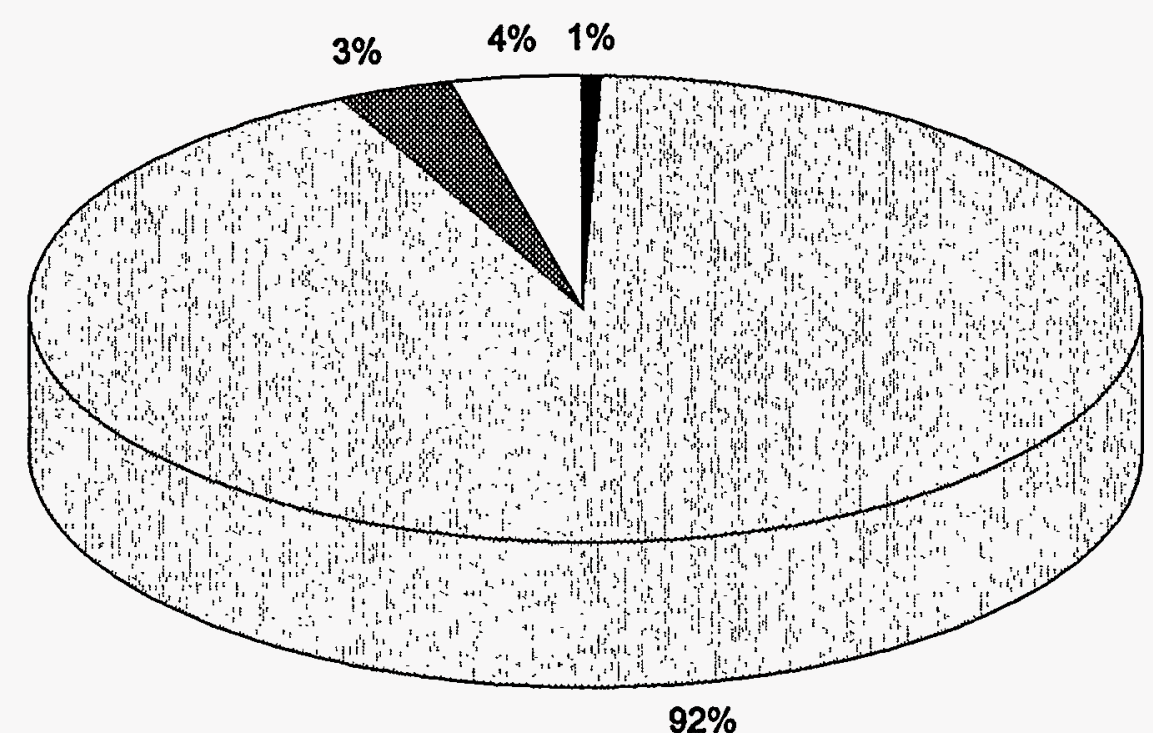

Lead Shielding

Inorganic Sludge

Inorganic Labpacks

Bulk (nontoxic) Metals 


\section{Figure 3.18. Radiological Distribution for Brookhaven National Laboratory Derived for the ITTS Study}

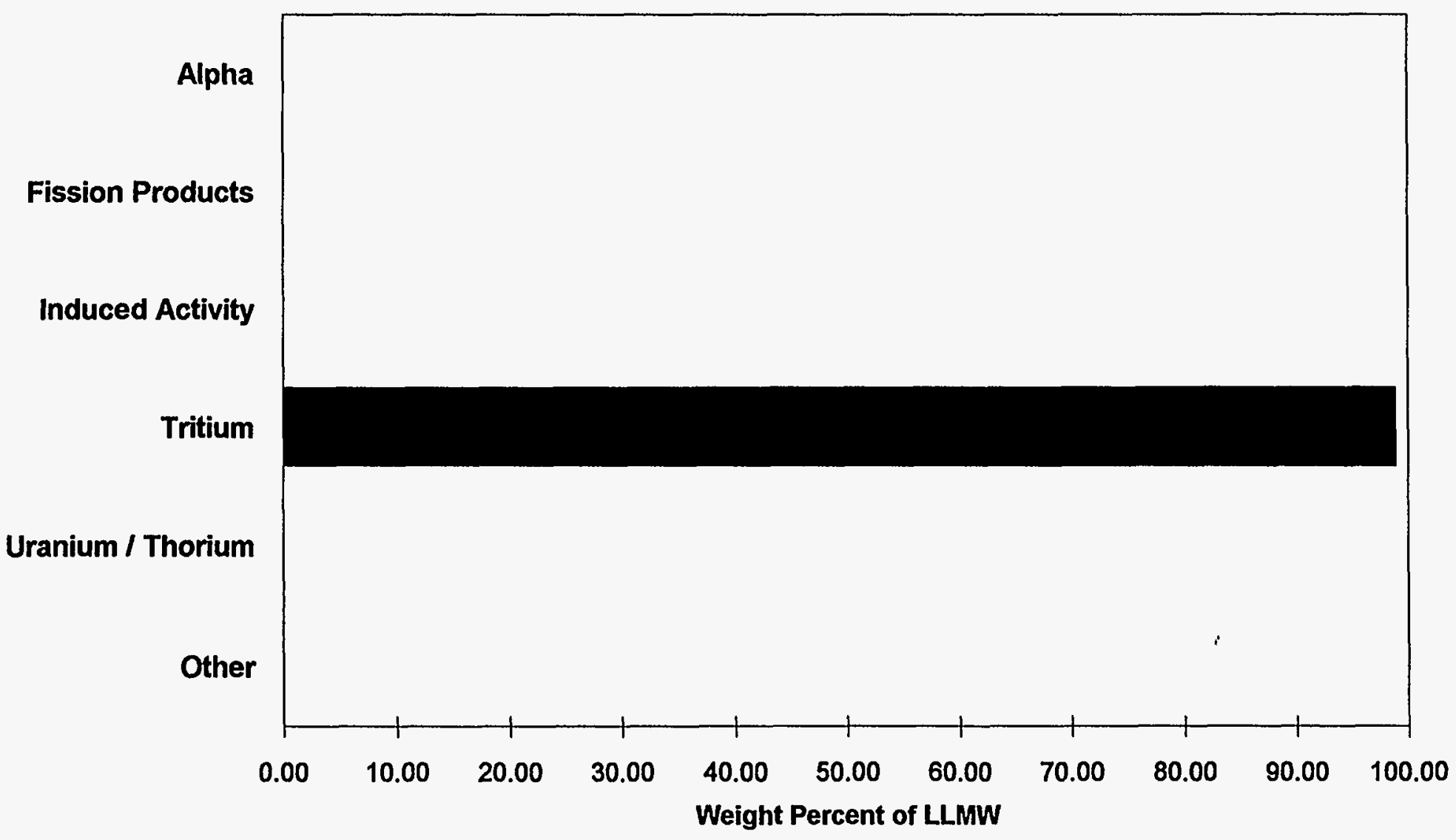




\section{Figure 3.19. Physical Matrix Distribution for Energy Technology Engineering Center Derived for the ITTS Study*}

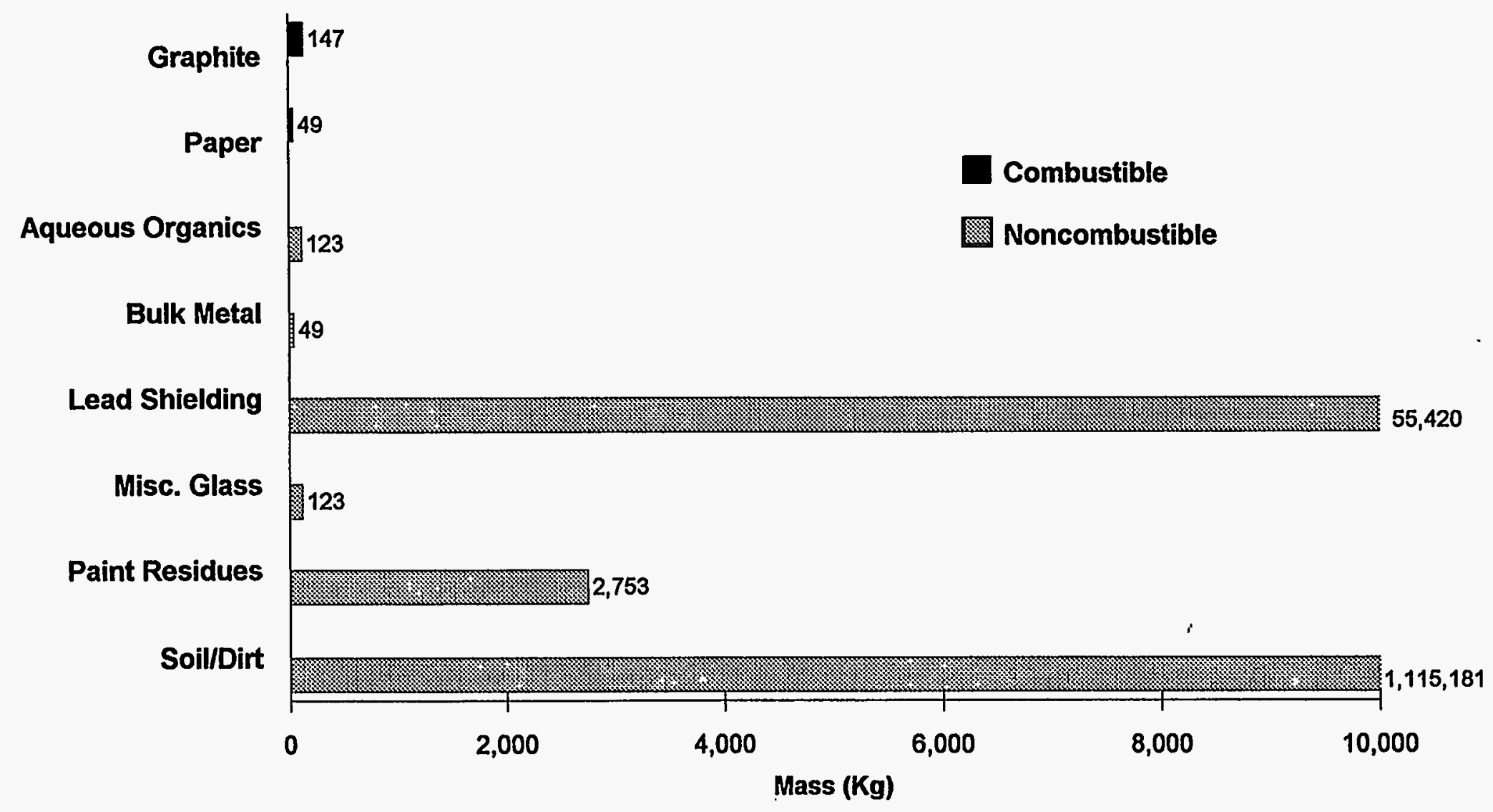

- Does not include mass due to containers.

Information obtained from the DOE/NBM-1100 (MWIR Report), April 1993. 


\section{Figure 3.20. Combustible vs Noncombustible for Energy Technology Engineering Center \\ Derived for the ITTS Study (TOTAL=1,173,844 Kg)*}

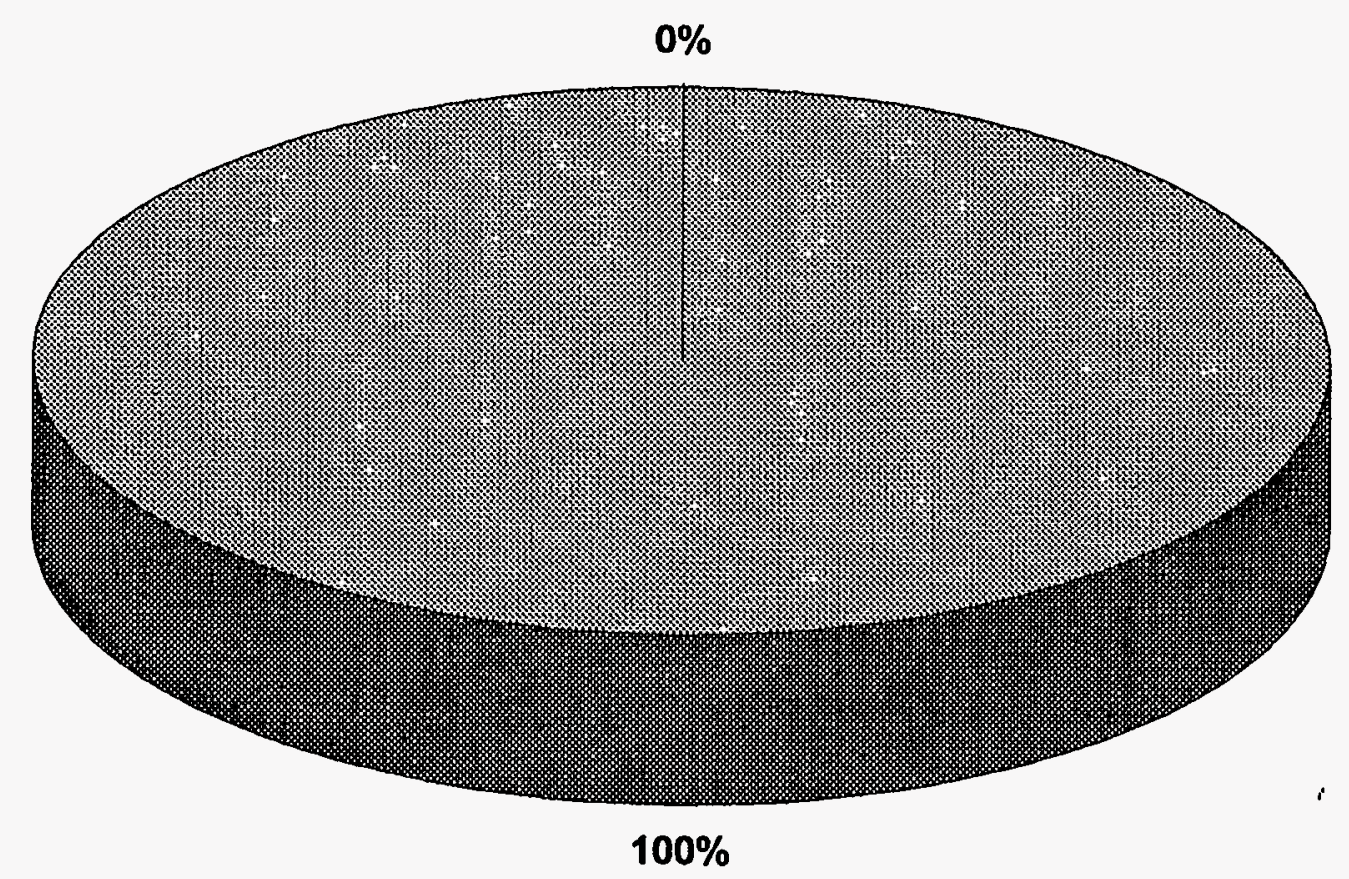

Combustible Noncombustible

* Does not include mass due to containers.

There are only $196 \mathrm{~kg}$ of combustibles (graphite and paper)

Information obtained from the DOE/NBM-1100 (MWIR Report), April 1993. 


\section{Figure 3.21. Noncombustible Physical Matrix Distribution for Energy Technology Engineering Center Derived for the ITTS Study (Noncombustibles=1,173,648 Kg)*}

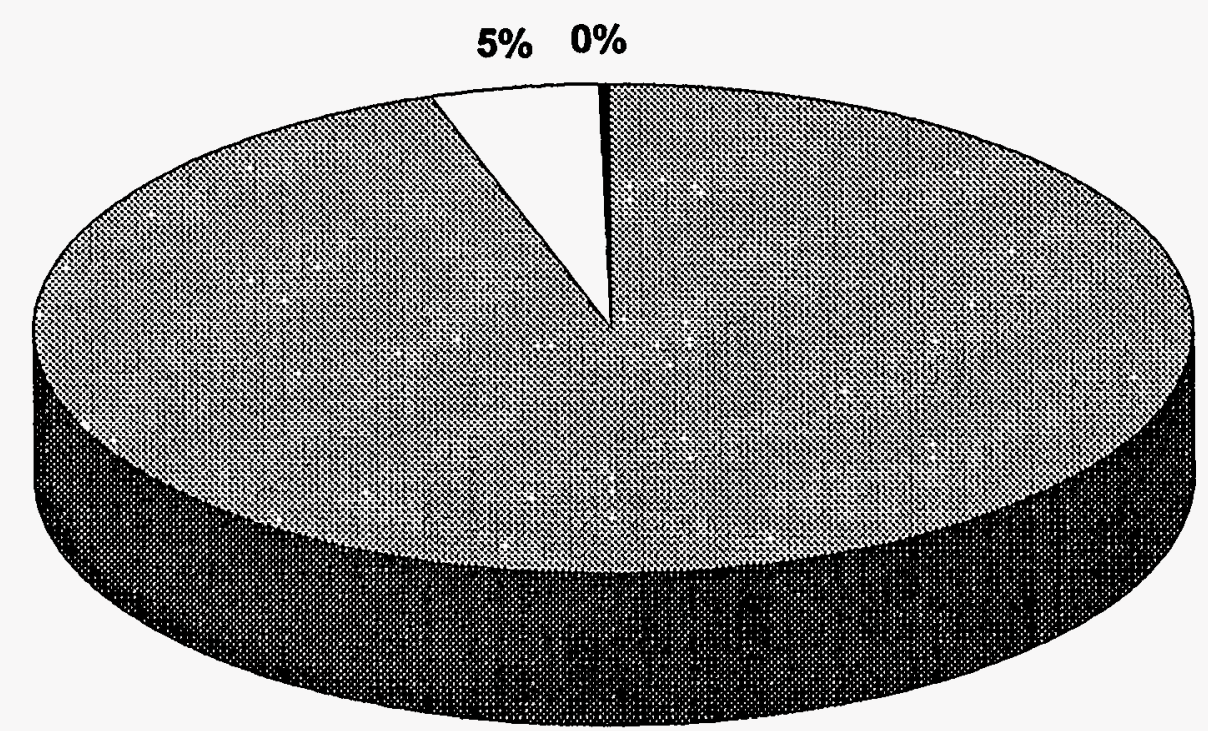

$95 \%$

Soil/Dirt $\square$ Lead Shielding $\square$ Other

* Does not include mass due to containers.

"Other" consists of Paint Residue, Misc. Glass, Bulk Metal, and Aqueous Organics.

Information obtained from the DOE/NBM-1100 (MWIR Report), April 1993. 


\section{Figure 3.22. Radiological Distribution for Energy Technology Engineering Center \\ Derived for the ITTS Study}

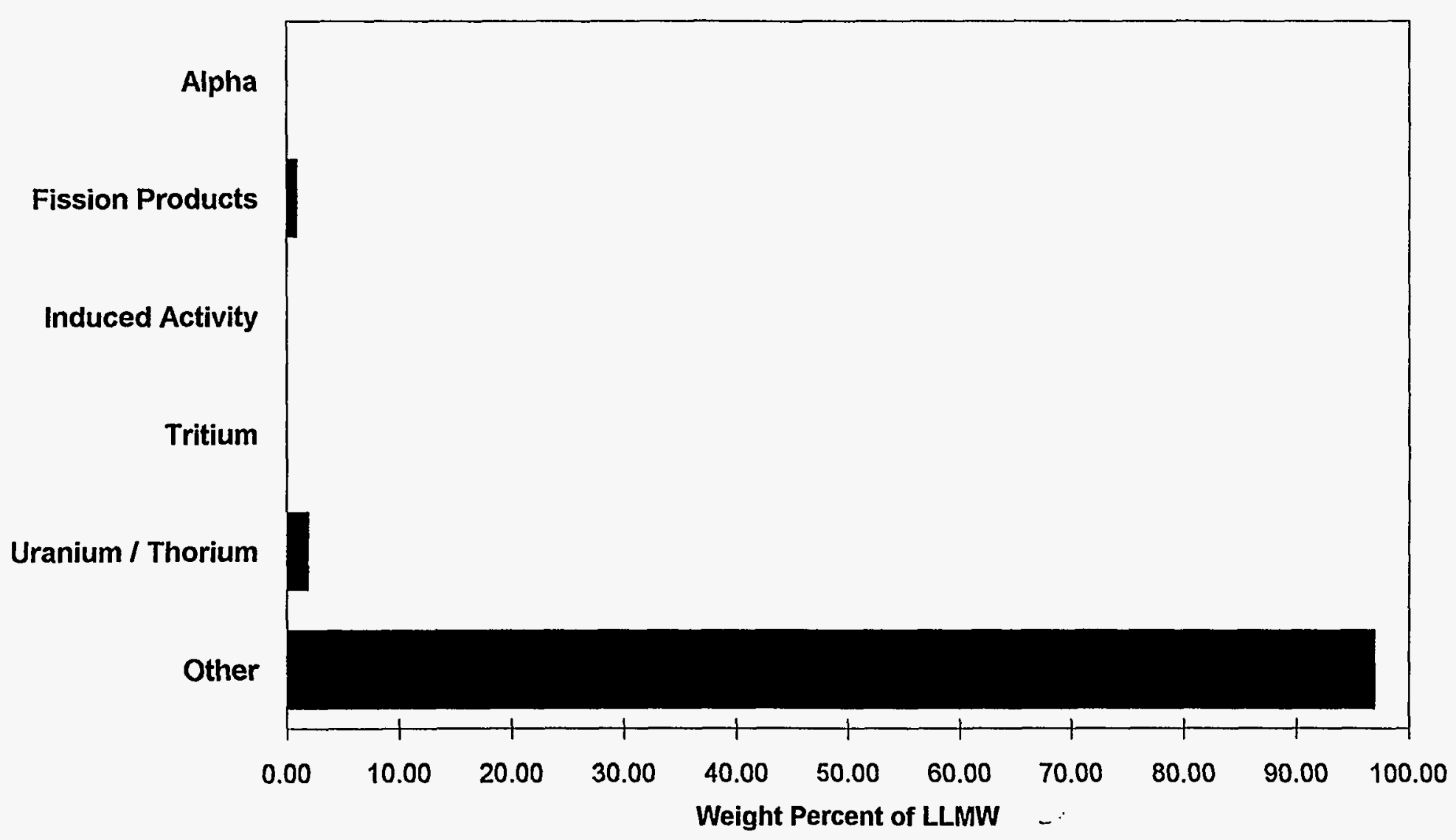




\section{Figure 3.23. Physical Matrix Distribution for Fernald Environmental Management Project Derived for the ITTS Study*}

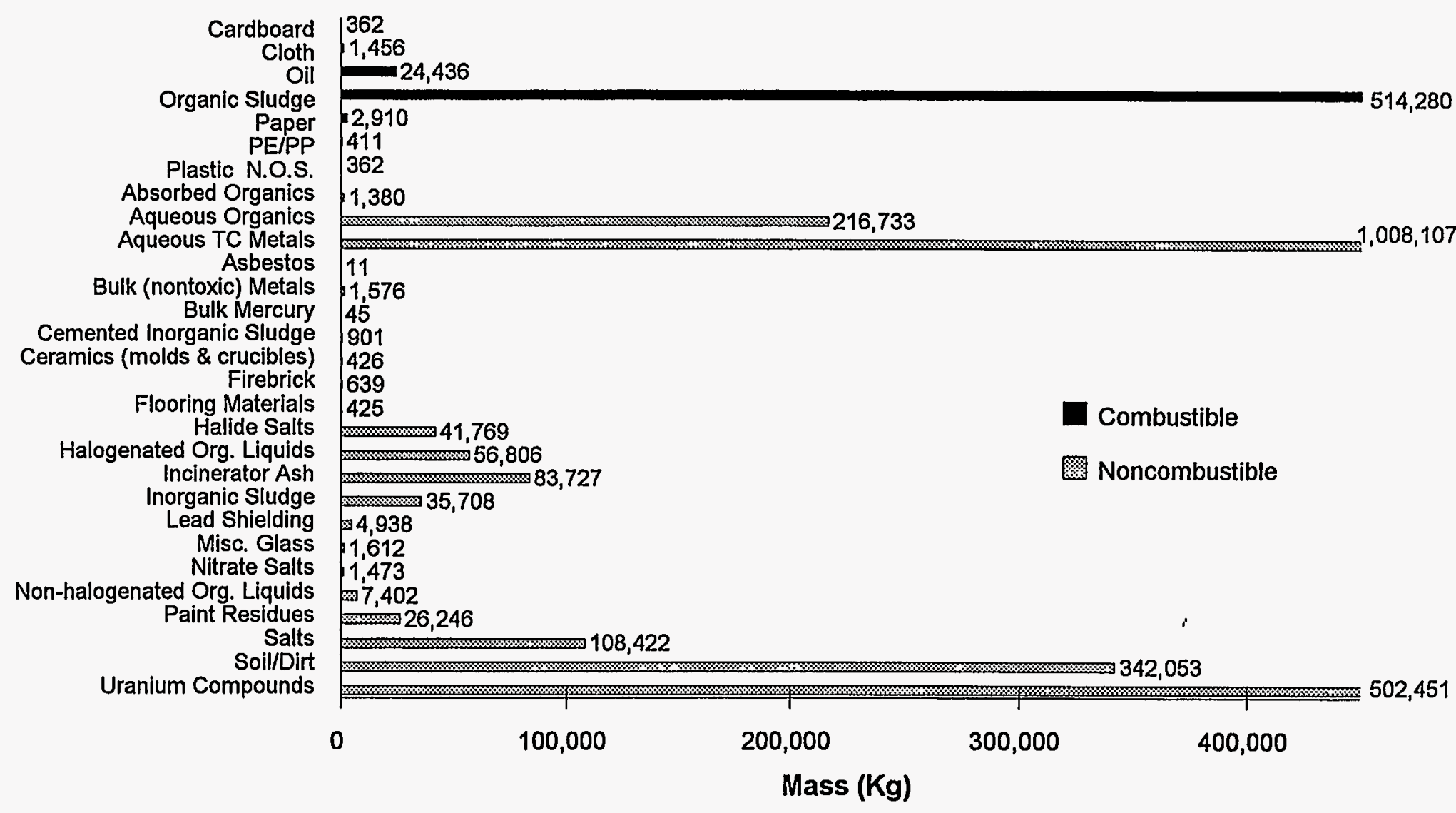

* Does not include mass due to containers.

Information obtained from the DOE/NBM-1100 (MWIR Report), April 1993. 


\section{Figure 3.24. Combustible vs Noncombustible for Fernald Environmental Management Project Derived for the ITTS Study (TOTAL=2,987,064 Kg)*}

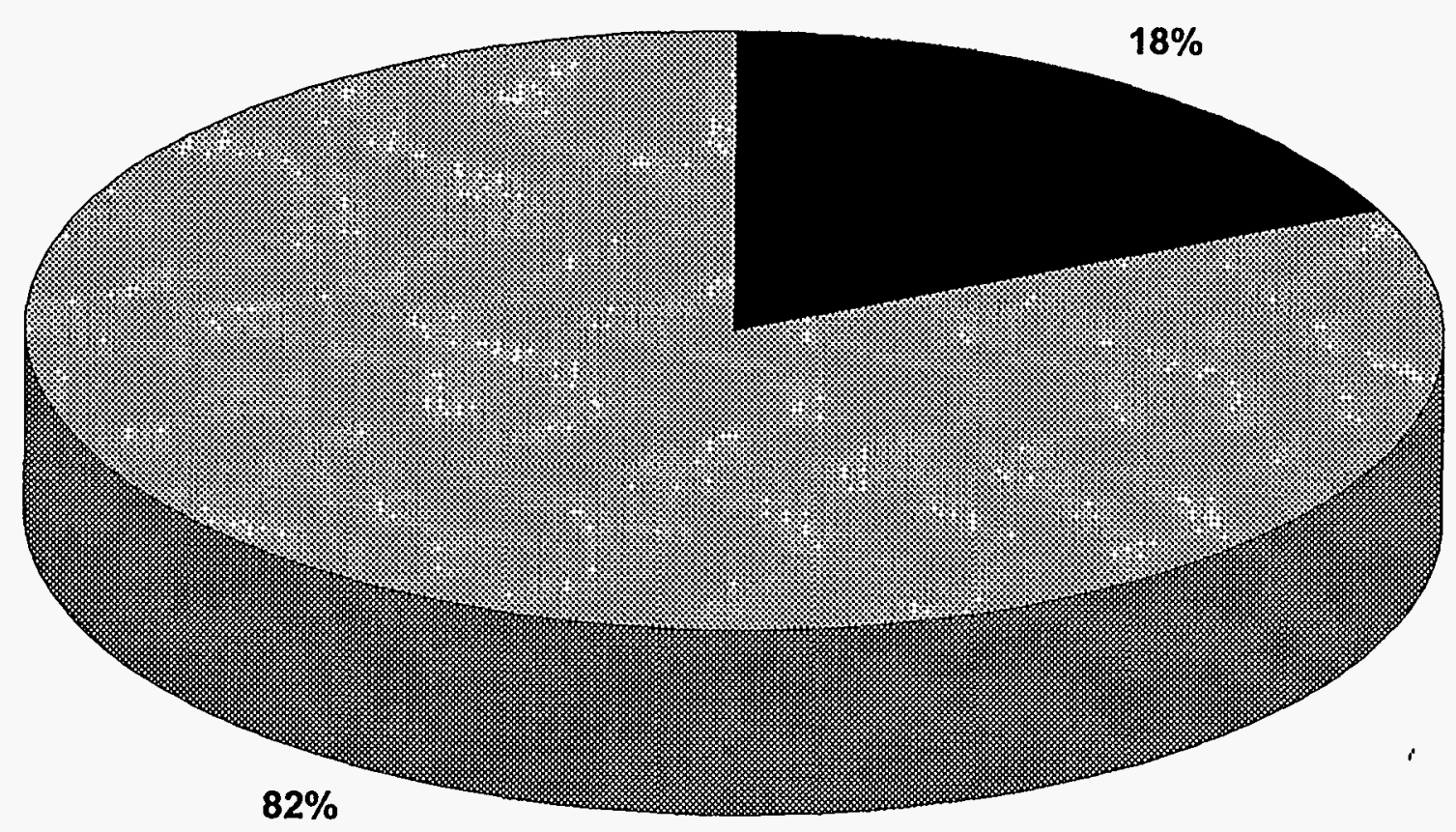

Combustible Noncombustible

* Does not include mass due to containers.

Information obtained from the DOE/NBM-1100 (MWIR Report), April 1993. 


\title{
Figure 3.25. Combustible Physical Matrix Distribution for Fernald Environmental Management Project Derived for the ITTS Study (Combustibles $=544,217 \mathrm{Kg})^{*}$
}

\author{
ํㅏㅄ Organic Sludge $\square$ Oil $\quad$ Other
}

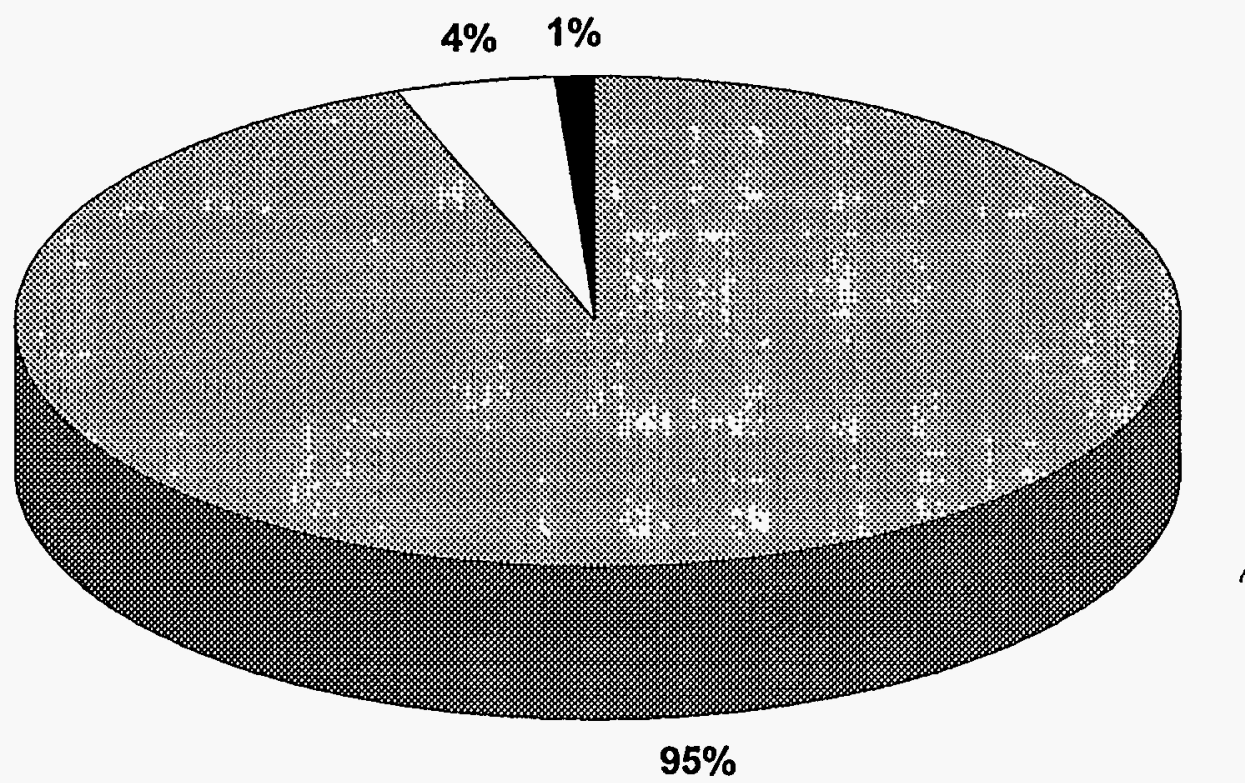




\section{Figure 3.26. Noncombustible Physical Matrix Distribution for Fernald Environmental Management Project Derived for the ITTS Study (Noncombustibes $=2,442,846 \mathrm{Kg}$ )}

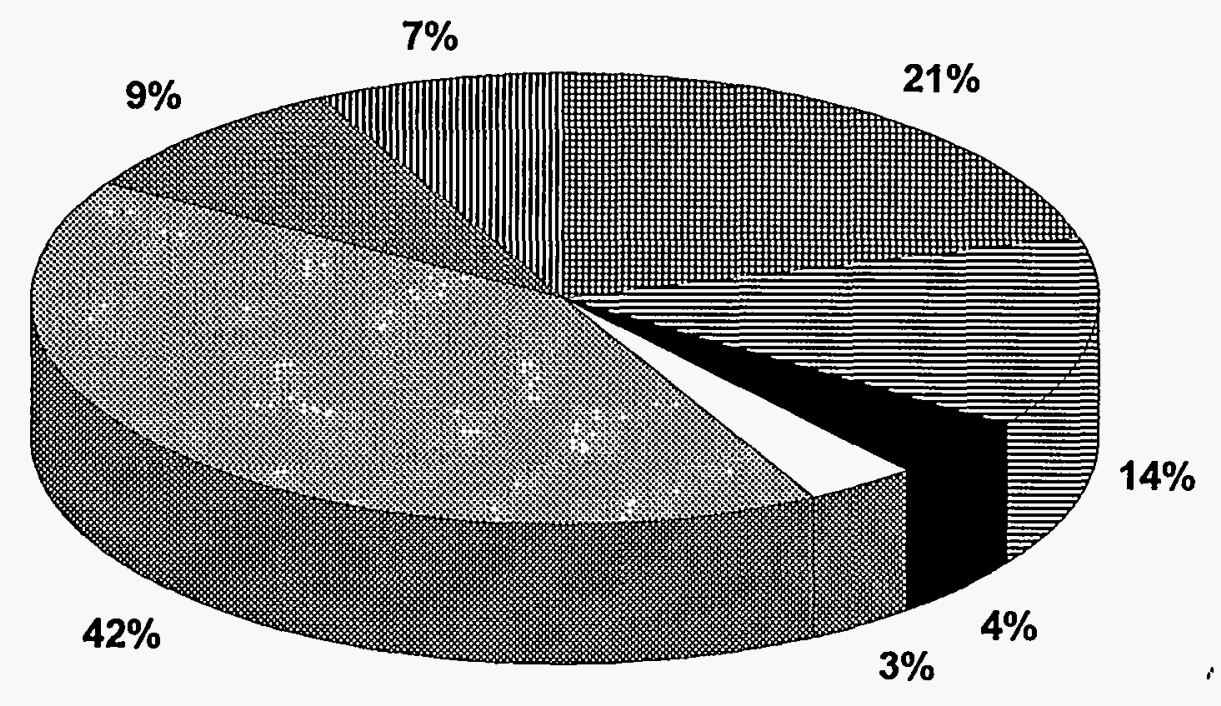

唾 Uranium 冒 Soil/Dirt $\quad \square$ Salts $\quad \square$ Incinerator Ash

相 Other

"Other" consists of Non-halo \& Halo Org Liq, Salt, Glass, Pb Shielding, Inorg Sludge, Flooring Mat., Firebrick, Ceramics, Bulk Metal \& $\mathrm{Hg}$, * Does not include mass due to containers. Information obtained from the DOE/NBM-1100 (MWIR Report), April 1993. Asbestos, Aque TC Metals, \& Aque \& Abs. Org. 


\section{Figure 3.27. Radiological Distribution for Fernald Environmental Management Project Derived for the ITTS Study}

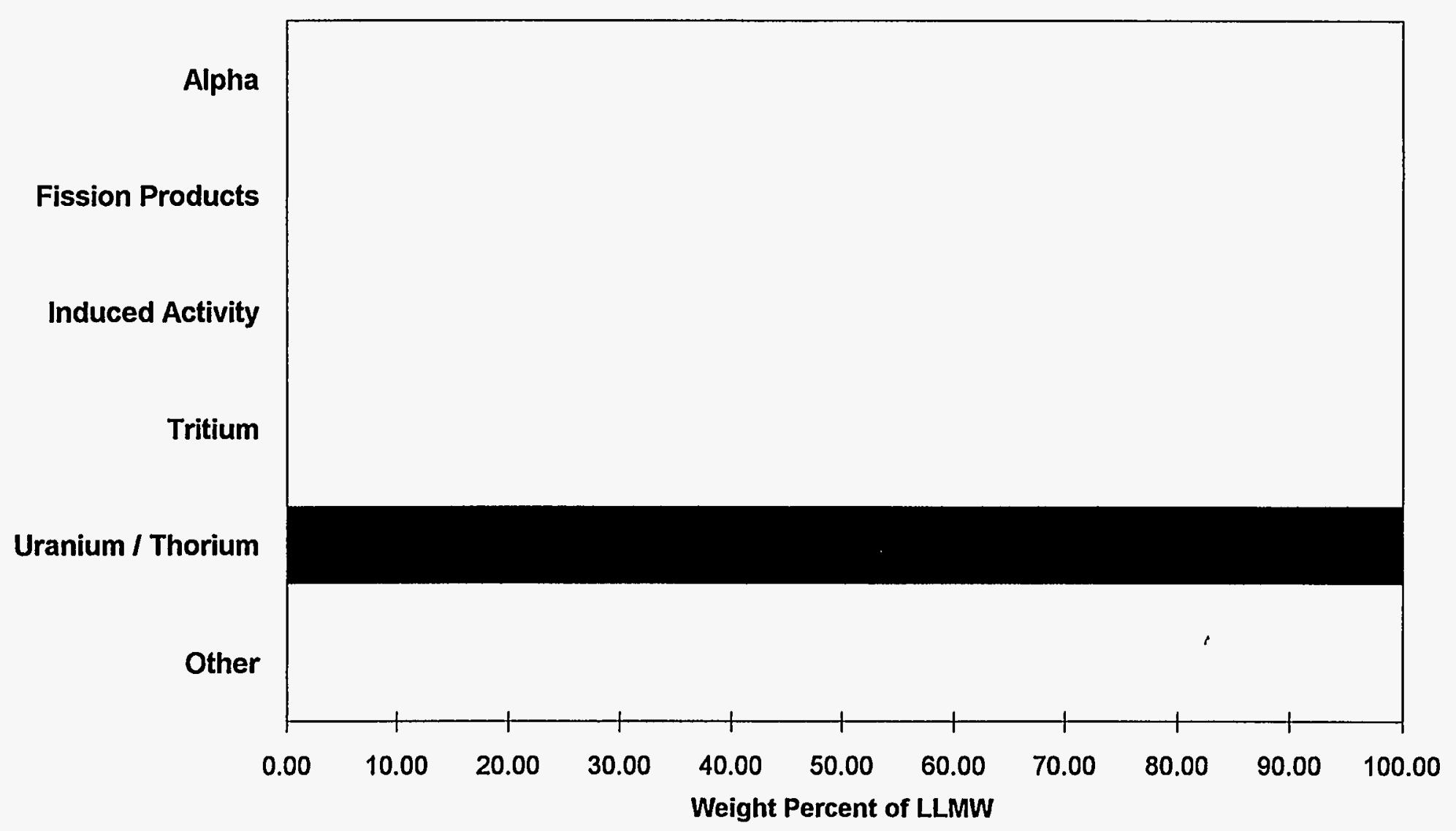




\section{Figure 3.28. Physical Matrix Distribution for Hanford Site Derived for the ITTS Study*}

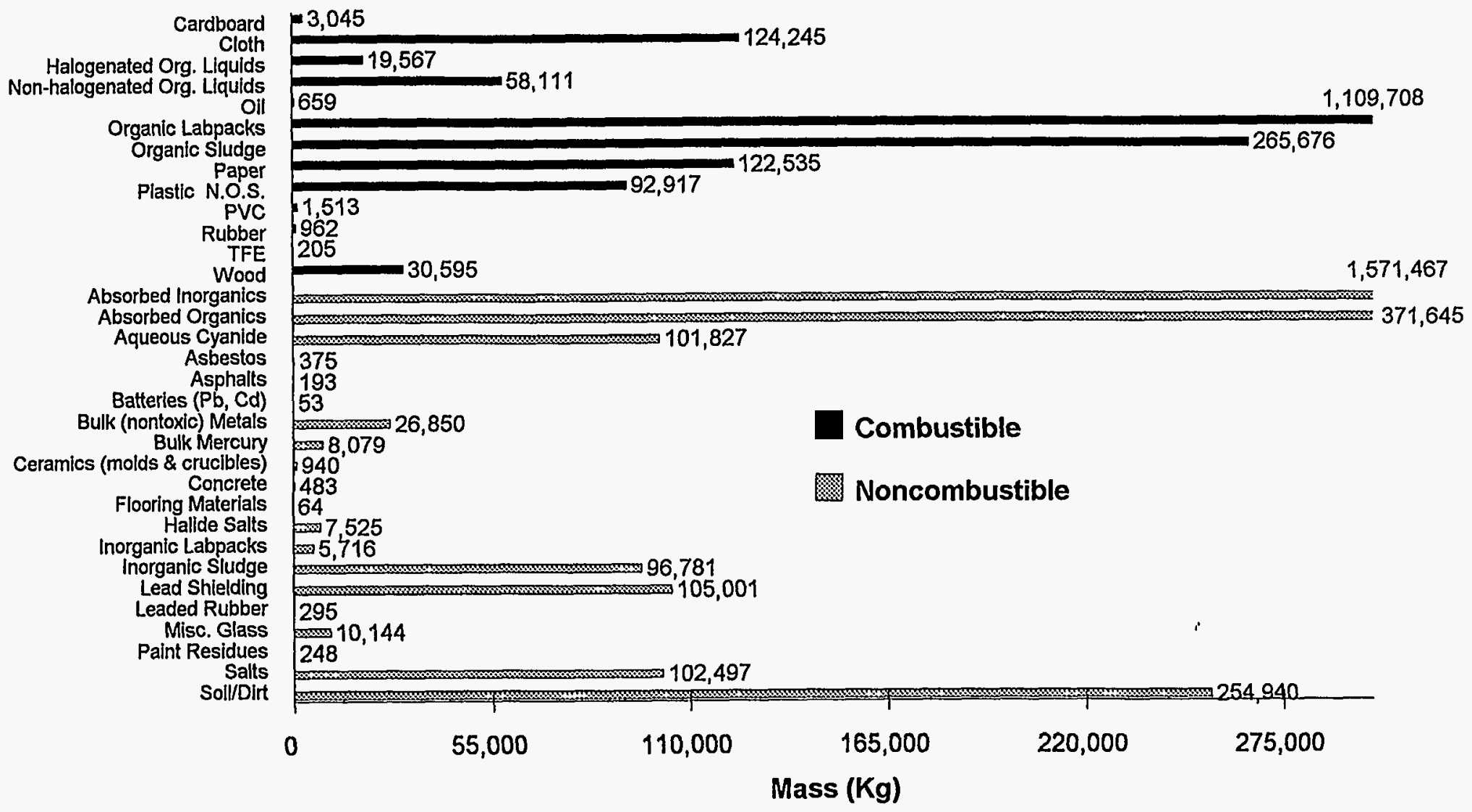

* Does not include mass due to containers.

Information obtained from the DOE/NBM-110 (MWIR Report), April 1993. 


\section{Figure 3.29. Combustible vs Noncombustible for Hanford Site Derived for the ITTS Study (TOTAL=4,494,859 Kg)*}

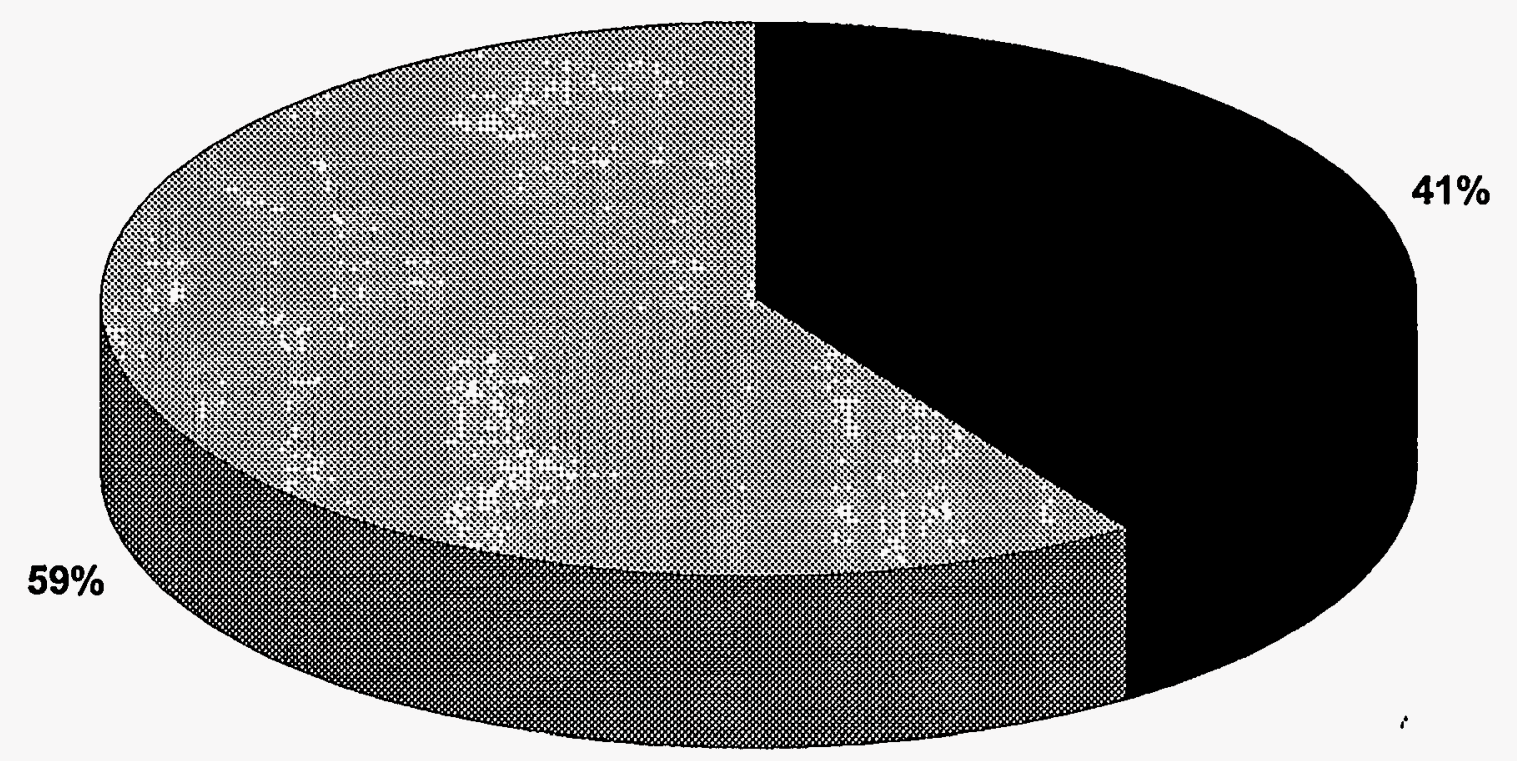

Combustible Noncombustible 


\section{Figure 3.30. Combustible Physical Matrix Distribution for Hanford Site Derived for the ITTS Study (Combustibles=1,829,737 Kg)*}

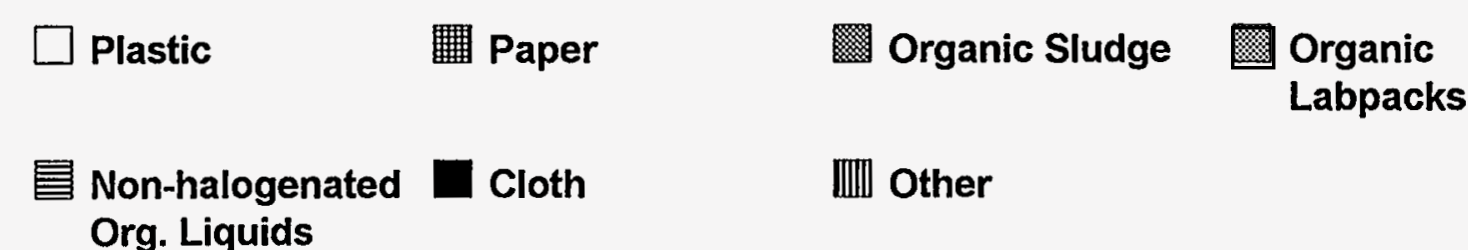

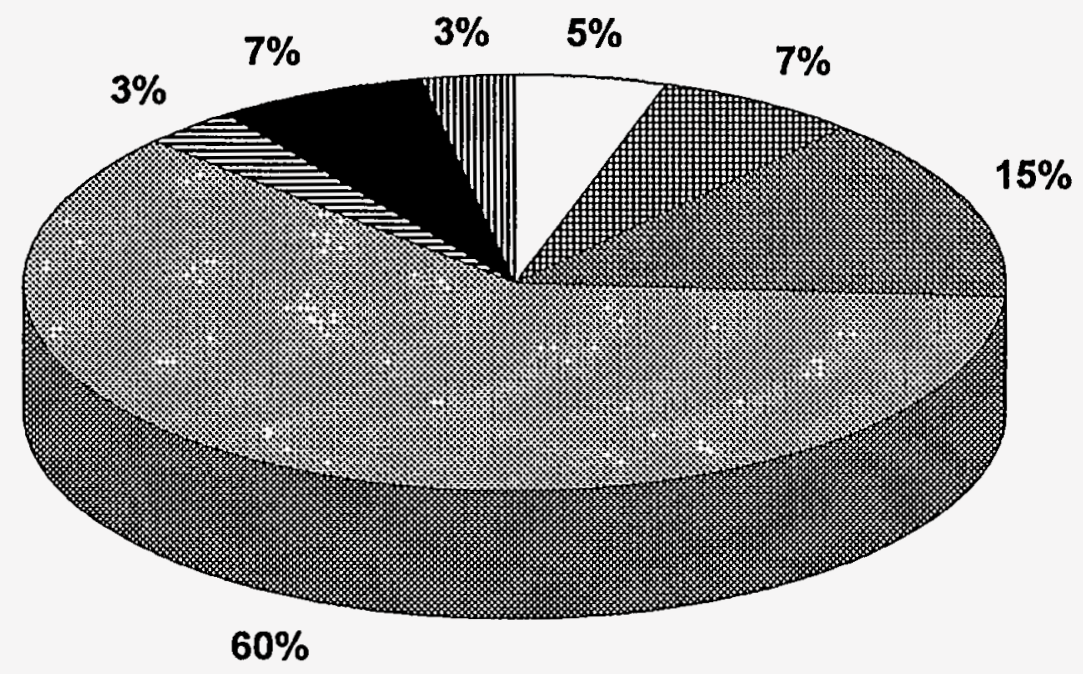

* Does not include mass due to containers.

"Other" consists of Oil, Halogenated Org. Liquid, Cardboard, Rubber, and Wood.

Information obtained from the DOE/NBM-110 (MWIR Report), April 1993. 


\section{Figure 3.31. Noncombustible Physical Matrix for Hanford Site Derived for the ITTS Study (Noncombustibles=2,665,123 Kg)*}

\begin{tabular}{|c|c|c|c|}
\hline Soil/Dirt & $\square$ salts & 血l Lead Shielding & Inorganic Sludge \\
\hline Aqueous Cyanide & Absorbed Organics & $\begin{array}{l}\text { Absorbed } \\
\text { Inorganics }\end{array}$ & Other \\
\hline
\end{tabular}

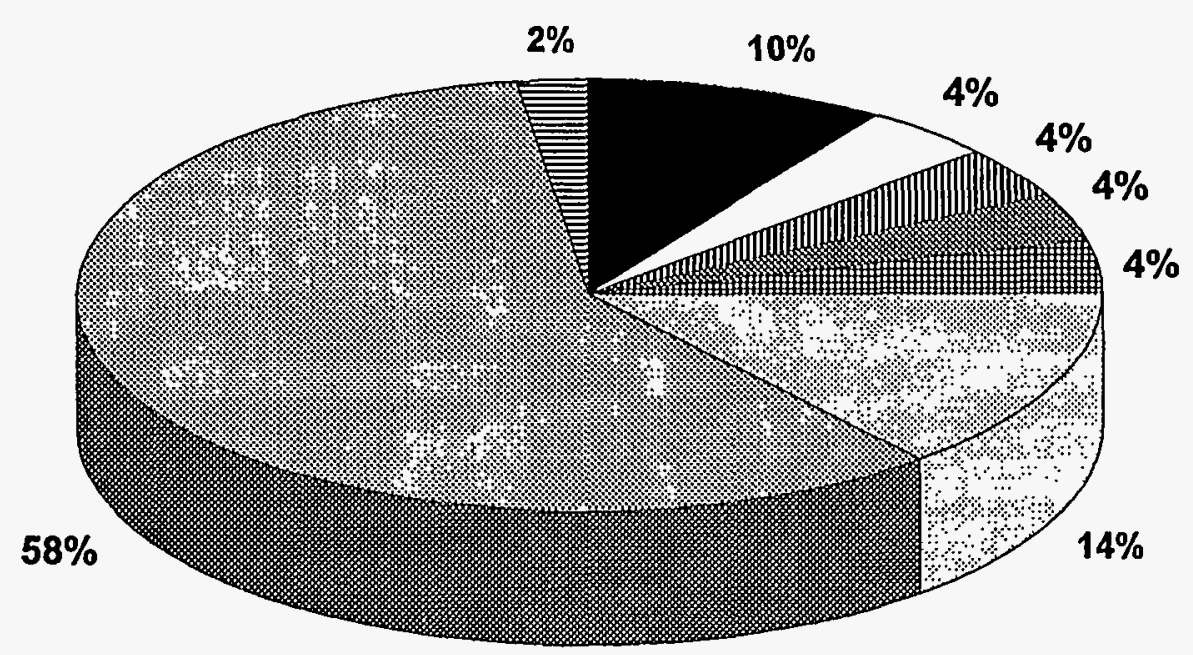

"Other" consists of Paint Residues, Glass, Leaded Rubber, Lead Sheilding, Inorganic Labpacks, Flooring Material, Concrete, Ceramics, Bulk Mercury, Bulk Metal, Batteries, Asphalt, and Asbestos. 


\section{Figure 3.32. Radiological Distribution for Hanford Site Derived for the ITTS Study}

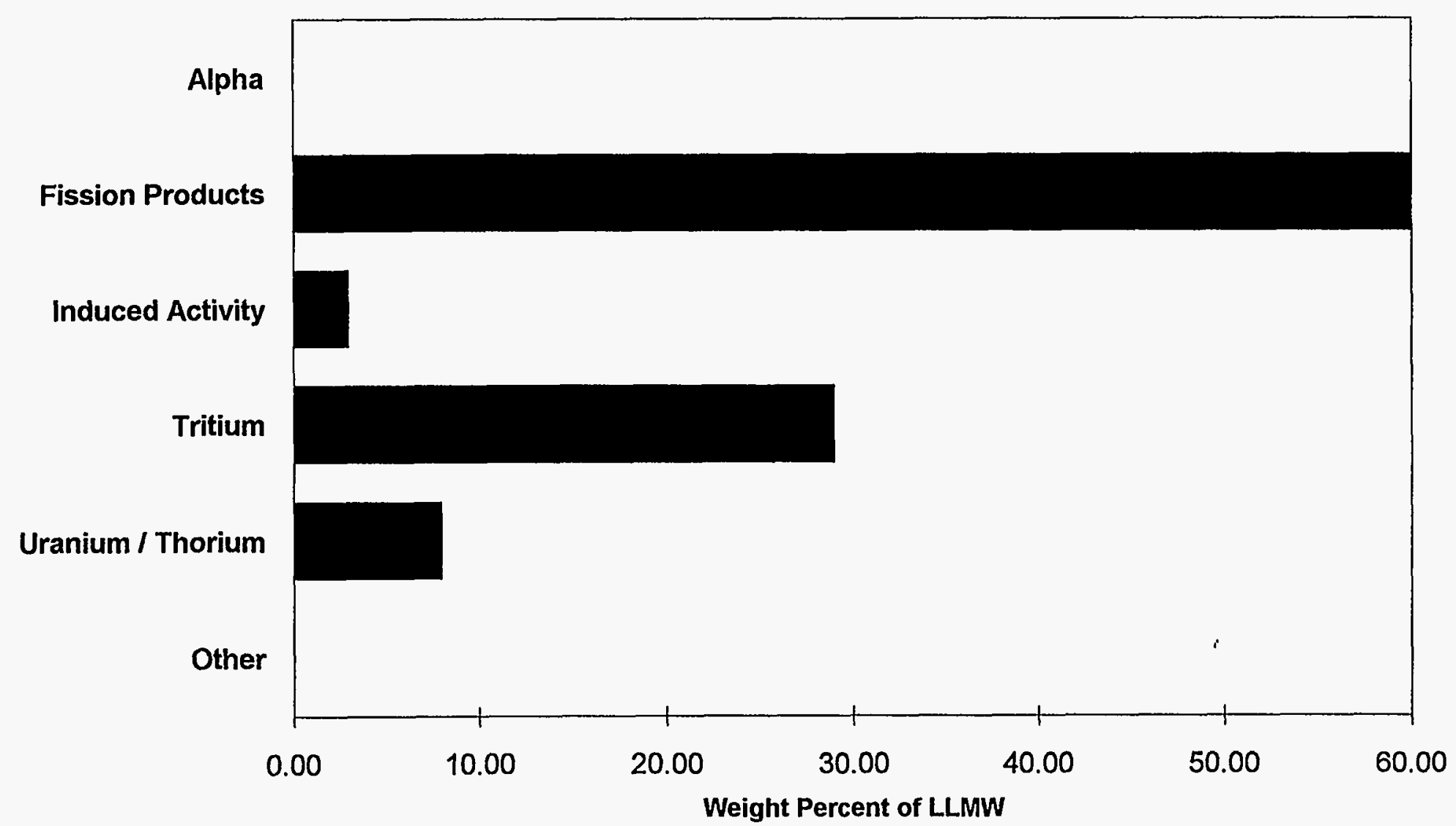

Information obtained from the DOE/RW-0006-Rev.8, October 1992 and EPA 520/1-91-010-2, May 1991. 


\section{Figure 3.33. Physical Matrix Distribution for Idaho National Engineering Laboratory Derived for the ITTS Study*}

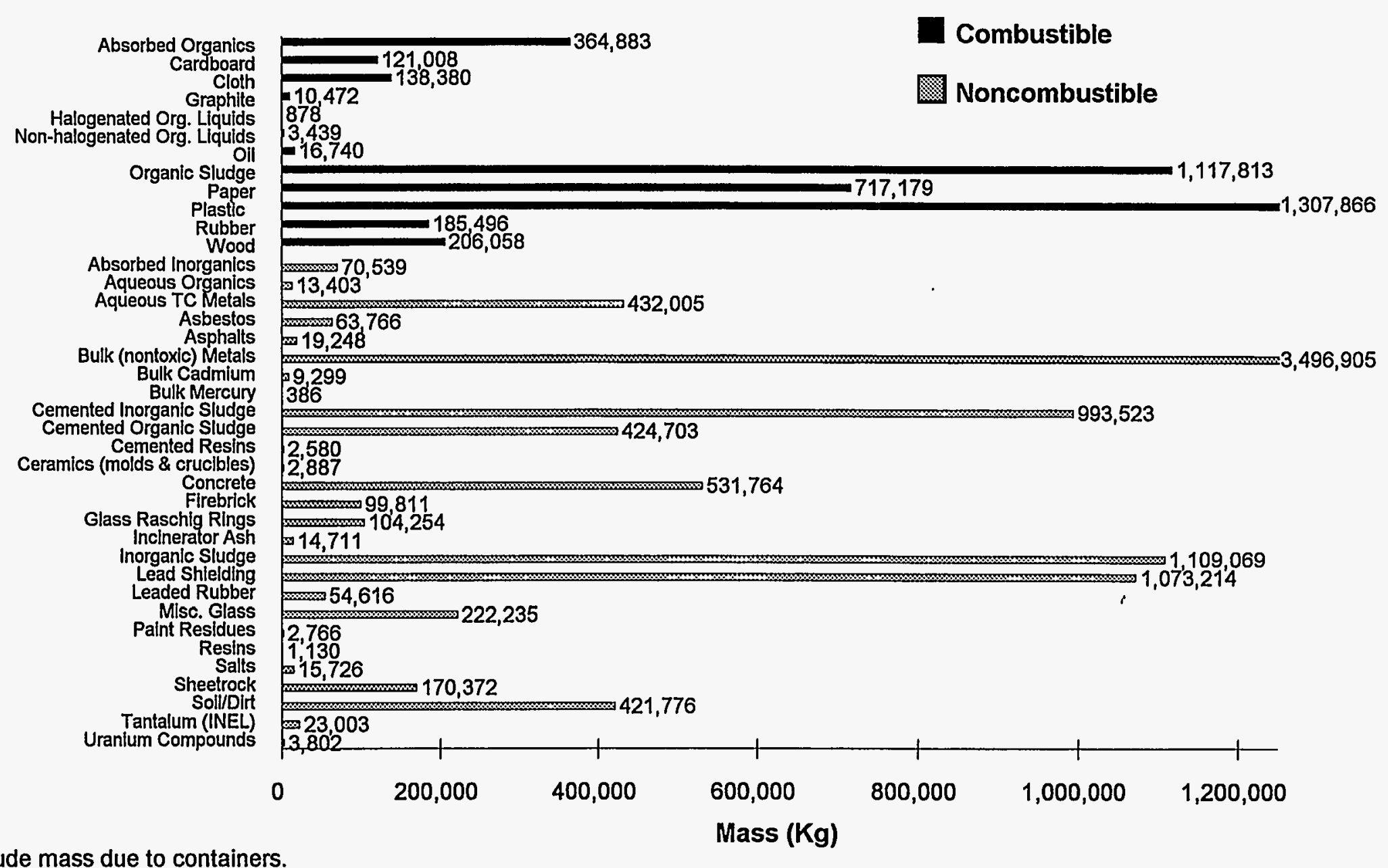

* Does not include mass due to containers.

Information obtained from the WM-PD-92-009, September 1992 and EGG-WM-10909, August 1993. 


\section{Figure 3.34. Combustible vs Noncombustible for Idaho National Engineering Laboratory Derived for the ITTS Study (TOTAL=13,567,705 Kg) ${ }^{*}$}

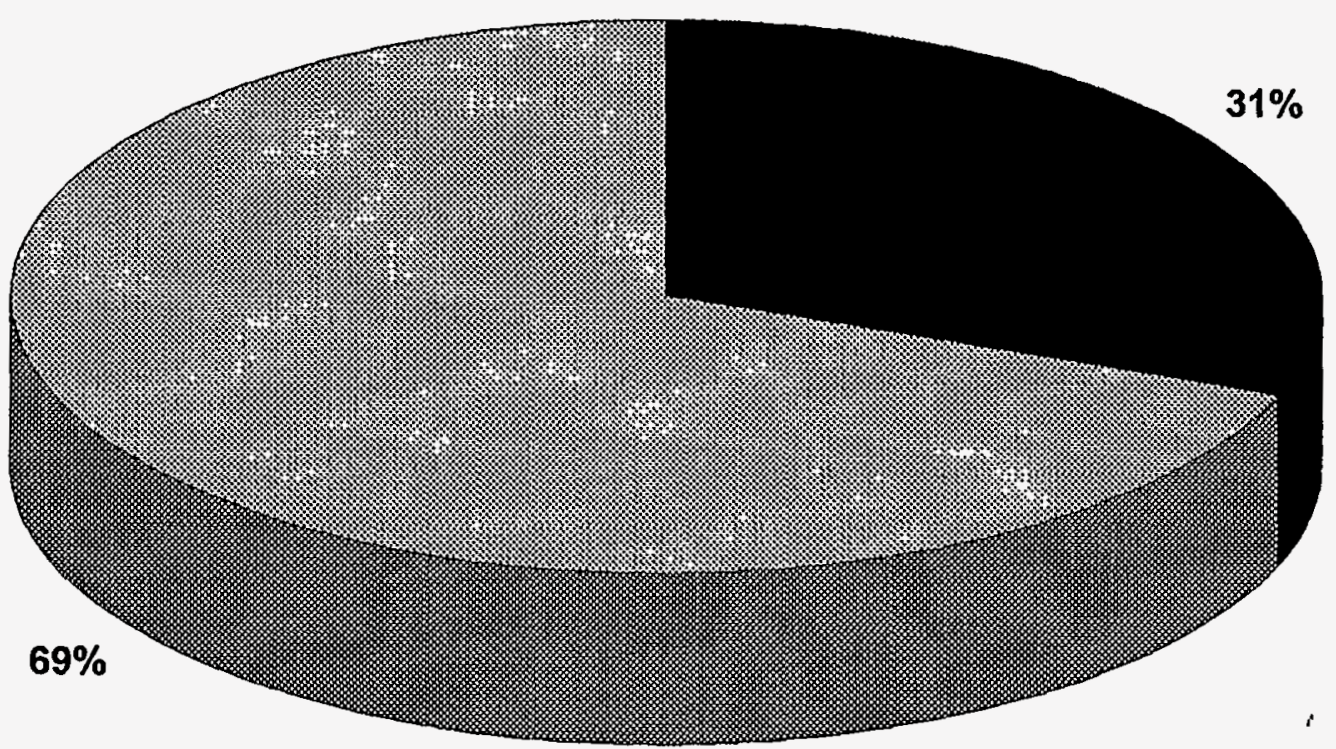

Combustible Noncombustible 


\section{Figure 3.35. Combustible Physical Matrix \\ Distribution for Idaho National Engineering Laboratory \\ Derived for the ITTS Study (Combustibles=4,190,213 Kg)*}

$\begin{array}{lll}\text { Rubber } & \text { Plastic } & \text { Inll Paper } \\ \text { Cardboard } & \begin{array}{c}\text { Absorbed } \\ \text { Organics }\end{array}\end{array}$

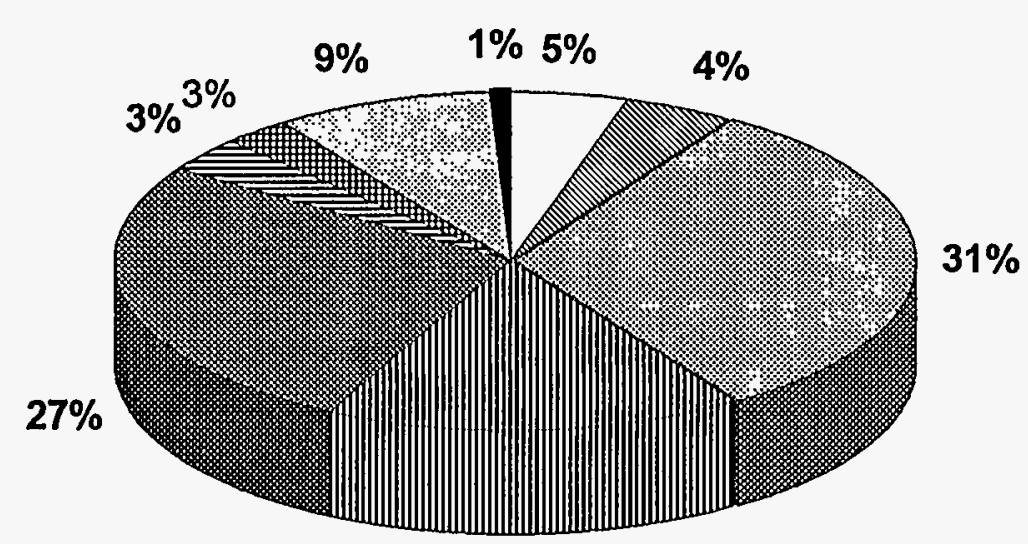

$17 \%$

* Does not include mass due to containers.

"Other" consists of Oil, Non-halogenated Org. Liquids, Halogenated Org. Liquids, and Graphite.

Information obtained from the WM-PD-92-009, September 1992 and EGG-WM-10909, August 1993. 


\section{Figure 3.36. Noncombustible Physical Matrix Distribution for Idaho National Engineering Laboratory Derived for the ITTS Study (Noncombustibles $=9,377,493 \mathrm{Kg}$ )}

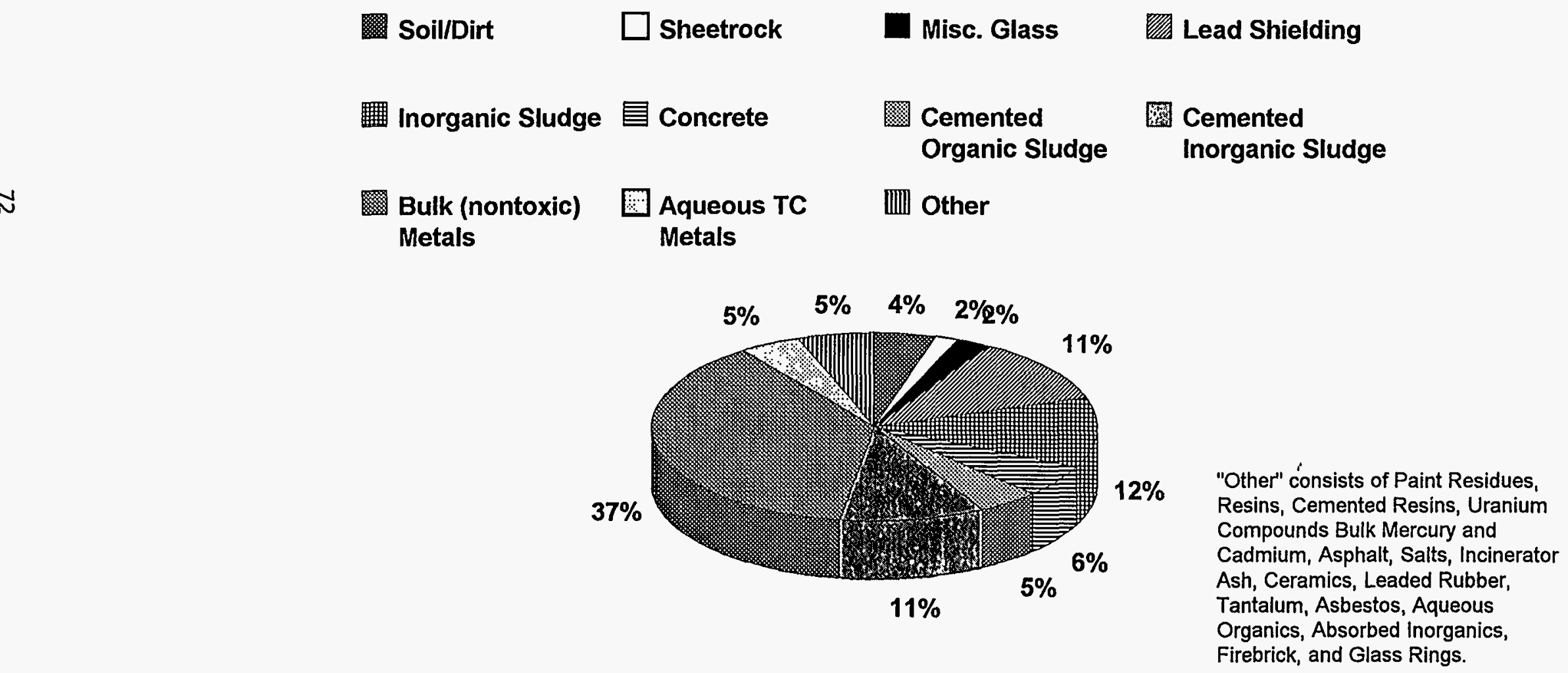

* Does not include mass due to containers.

Information obtained from the WM-PD-92-009 September 1992 and EGG-WM-10909, August 1993. 


\section{Figure 3.37. Radiological Distribution for Idaho National Engineering Laboratory Derived for the ITTS Study}

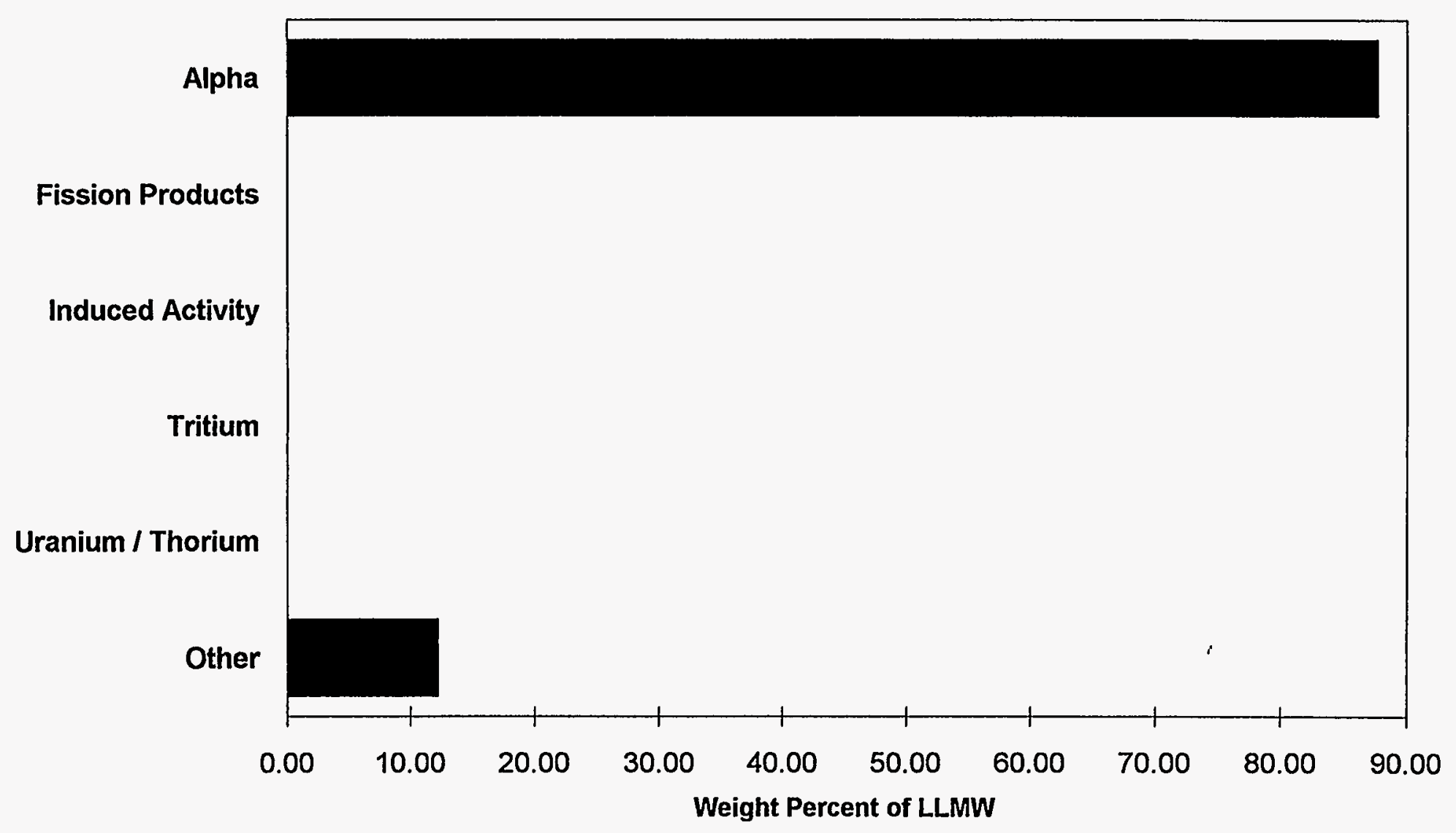

Information obtained from the WM-PD-92-009, September 1992 and EPA 520/1-91-010-2, May 1991. 


\section{Figure 3.38. Physical Matrix Distribution for Lawrence Livermore National Laboratory Derived for the ITTS Study*}

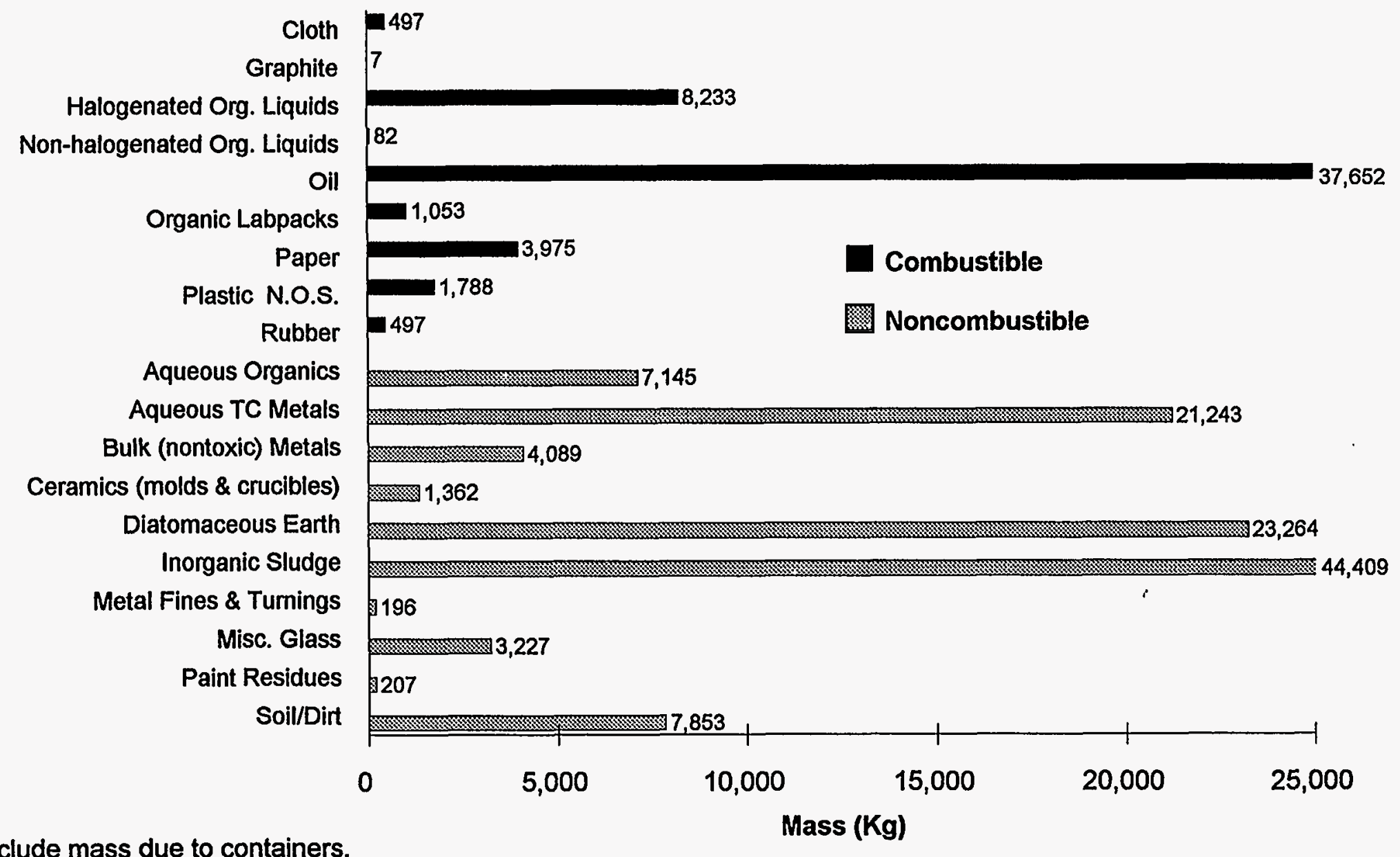

* Does not include mass due to containers.

Information obtained from the DOE/NBM-1100 (MWIR Report), April 1993. 


\section{Figure 3.39. Combustible vs Noncombustible for Lawrence Livermore National Laboratory Derived for the ITTS Study (TOTAL=166,778 Kg)*}

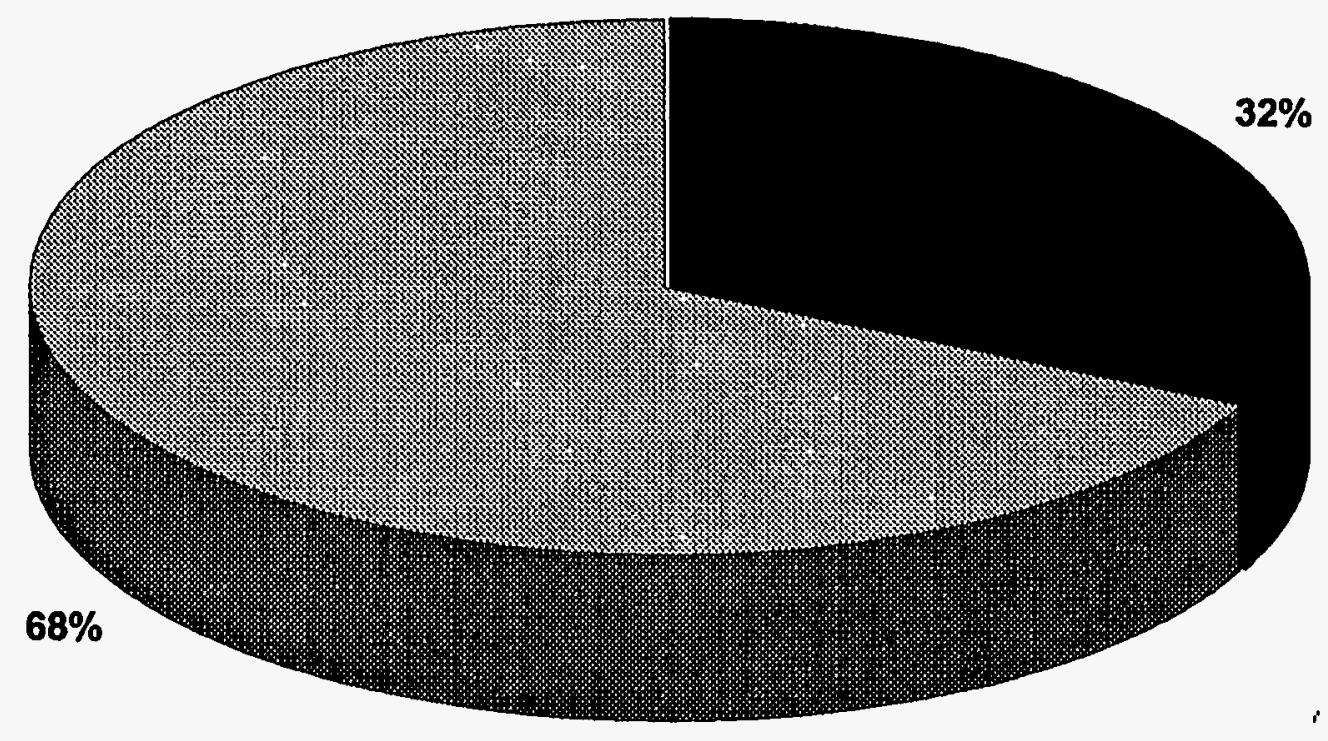

Combustible Noncombustible 


\section{Figure 3.40. Combustible Physical Matrix Distribution for Lawrence Livermore National Laboratory Derived for the ITTS Study (Combustibles $=53,783 \mathrm{Kg}$ )*}
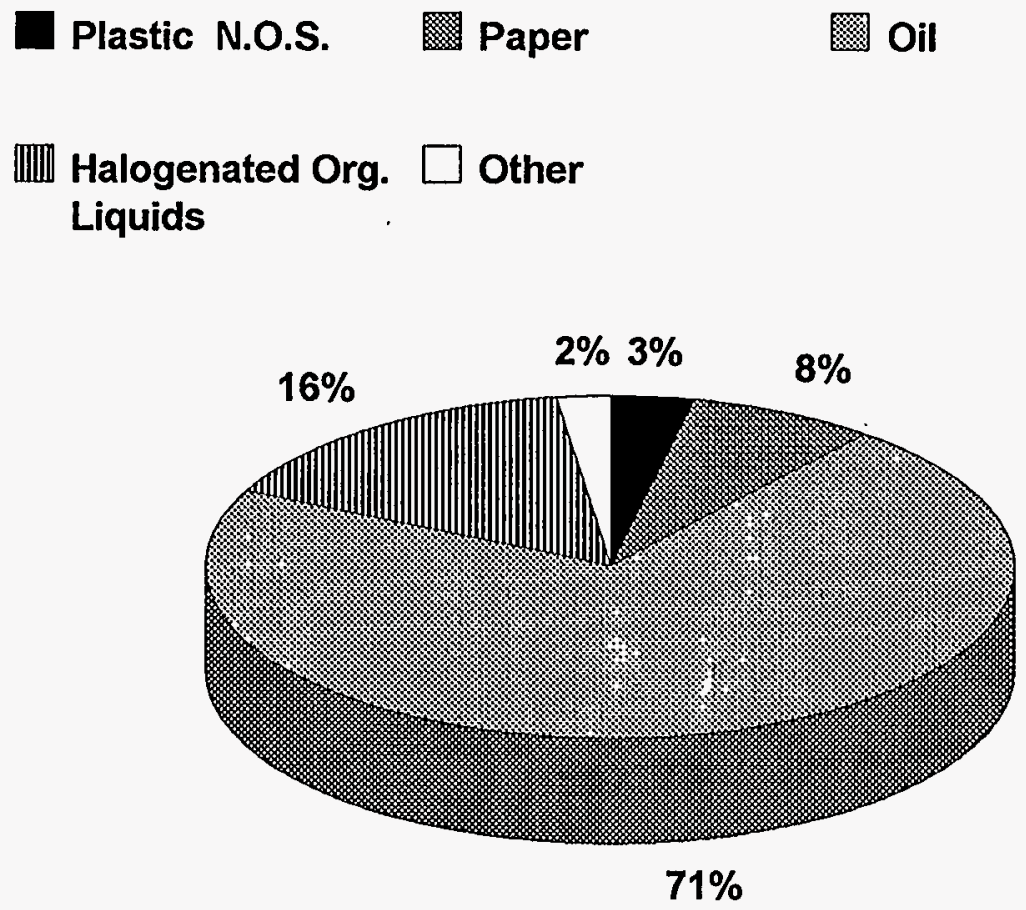

* Does not include mass due to containers.

"Other" consists of Non-halogenated Org. Liquids, Graphite, Cloth, Rubber, and Organic Labpacks. Information obtained from the DOE/NBM-1100 (MWIR Report), April 1993. 


\section{Figure 3.41. Noncombustible Physical Matrix Distribution for Lawrence Livermore National Laboratory Derived for the ITTS Study (Noncombustibles $=112,995 \mathrm{Kg}$ )*}

Inorganic Sludge 睡 Diatomaceous Earth

㳑 Other

Aqueous TC Metals

Aqueous
Organics

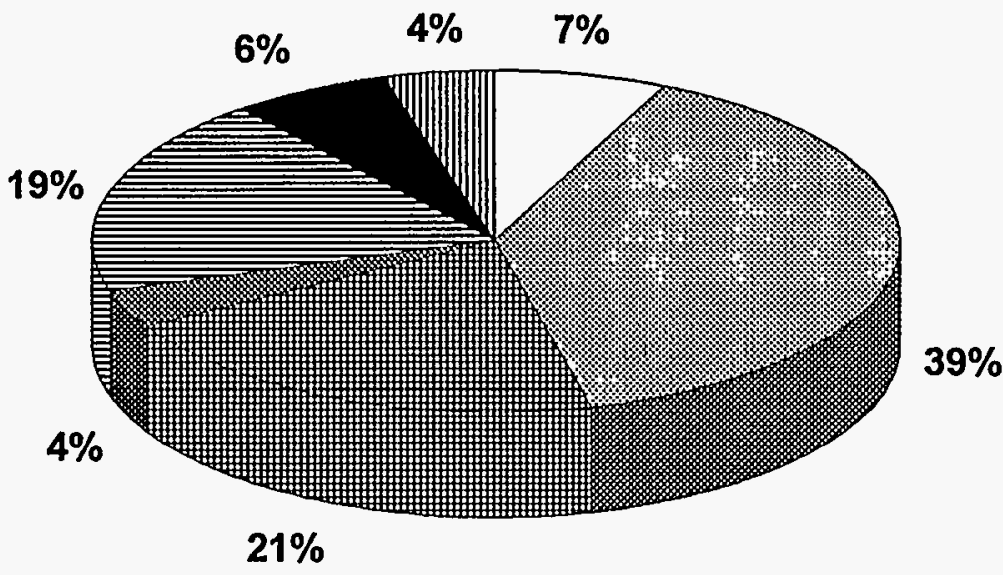




\section{Figure 3.42. Radiological Distribution for Lawrence Livermore National Laboratory Derived for the ITTS Study}

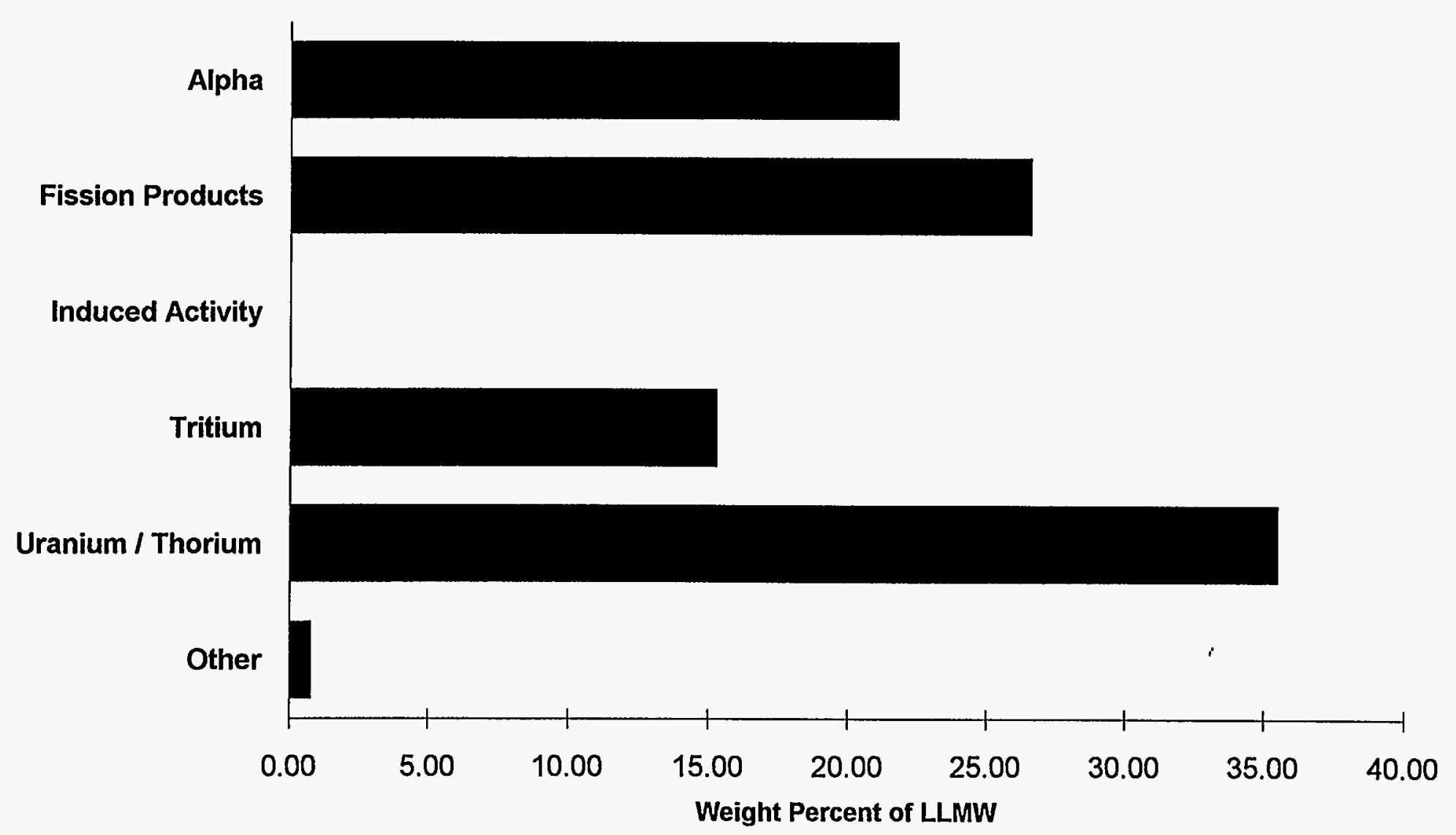

Information obtained from the DOE/RW-0006-Rev.8, October 1992 and EPA 520/1-91-010-2, May 1991. 


\section{Figure 3.43. Physical Matrix Distribution for Los Alamos National Laboratory Derived for the ITTS Study*}

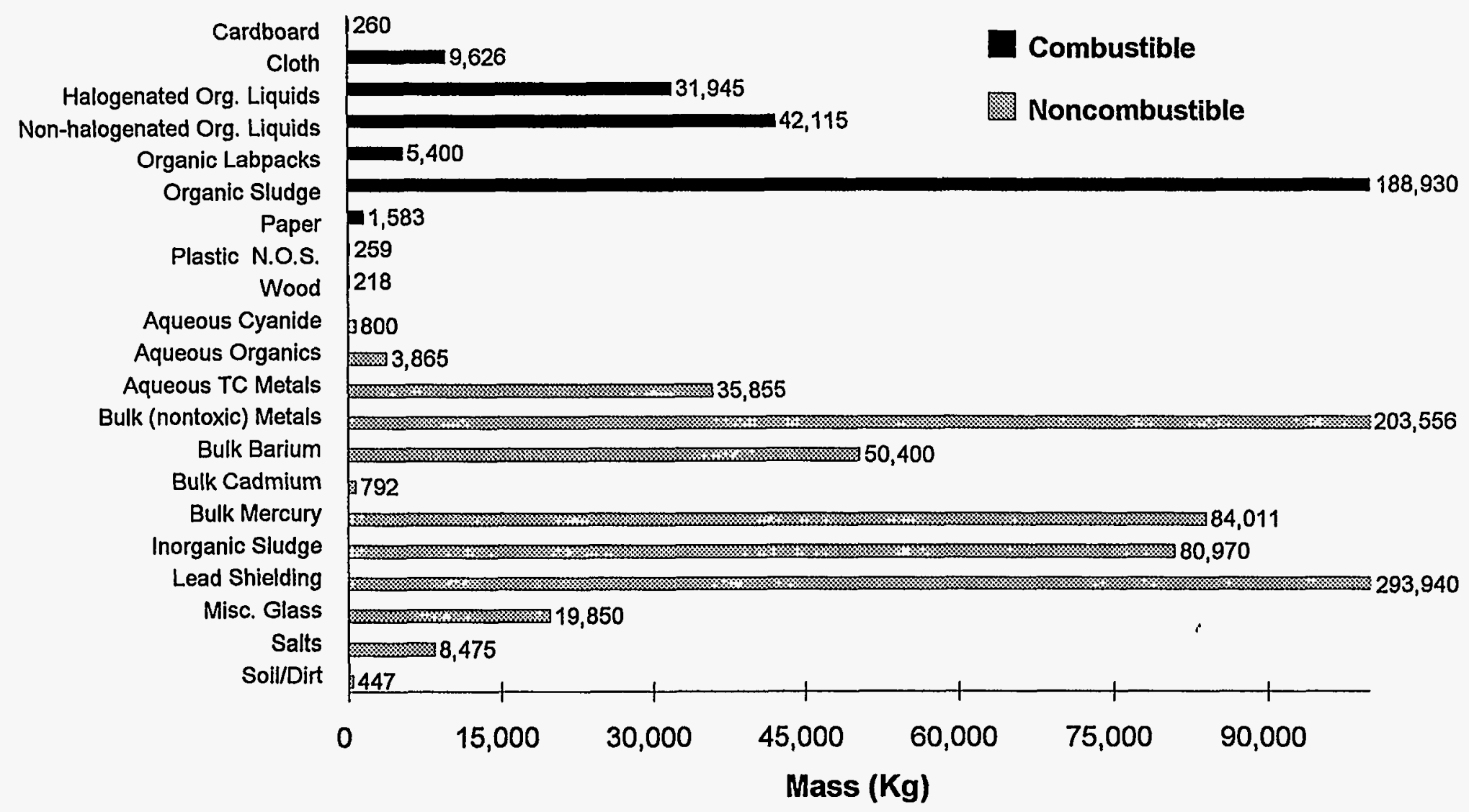

* Does not include mass due to containers.

Information obtained from the DOE/NBM-1100 (MWIR Report), April 1993. 


\section{Figure 3.44. Combustible vs Noncombustible for Los Alamos National Laboratory Derived for the ITTS Study (TOTAL=1,063,295 Kg)*}

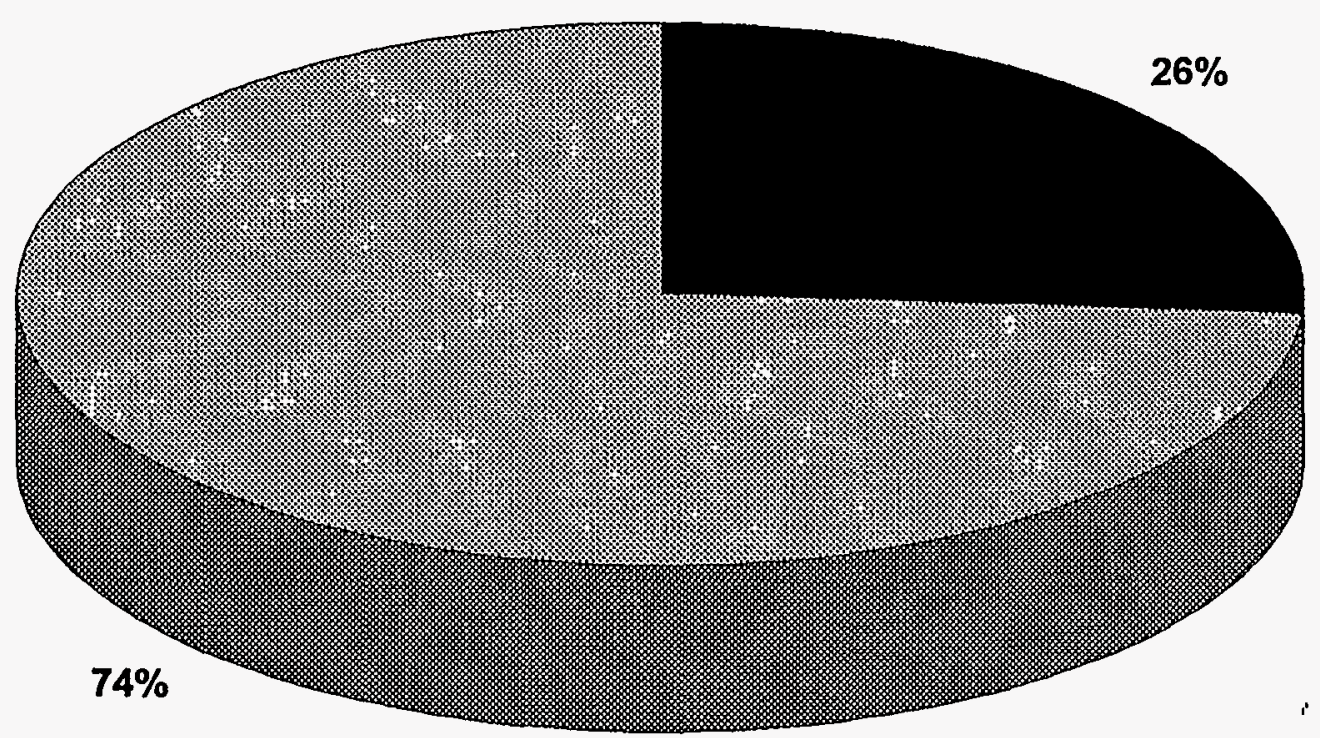

Combustible Noncombustible 


\title{
Figure 3.45. Combustible Physical Matrix Distribution for Los Alamos National Laboratory Derived for the ITTS Study (Combustibles $=280,336 \mathrm{Kg}$ )
}
Organic Sludge Non-halogenated
Halogenated Org. \\ Org. Liquids \\ Liquids \\ [ Cloth $\square$ other
}

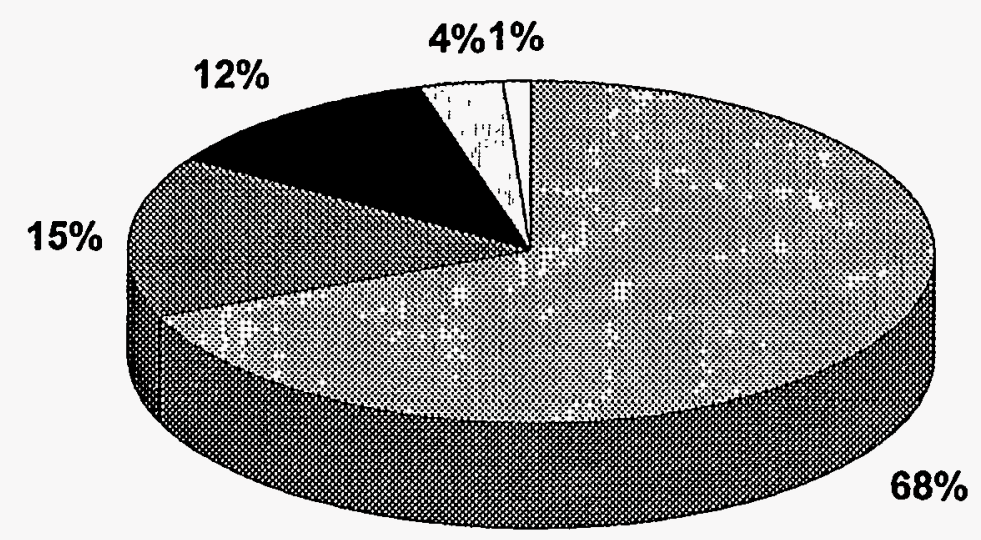

- Does not include mass due to containers.

"Other" consists of Wood Products, Plastic, and Organic Labpacks.

Information obtained from the DOE/NBM-1100 (MWIR Report), April 1993. 


\section{Figure 3.46. Noncombustible Physical Matrix Distribution for Los Alamos National Laboratoy Derived for the ITTS Study (Noncombustibles $=782,960 \mathrm{Kg})^{*}$}

\begin{tabular}{|c|c|c|c|}
\hline IIIII Misc. Glass & Lead Shielding & 典 Inorganic Sludge & Bulk Mercury \\
\hline Bulk Barium & $\begin{array}{l}\text { Bulk (nontoxic) } \\
\text { Metals }\end{array}$ & $\begin{array}{l}\square \text { Aqueous TC } \\
\text { Metals }\end{array}$ & Other \\
\hline
\end{tabular}

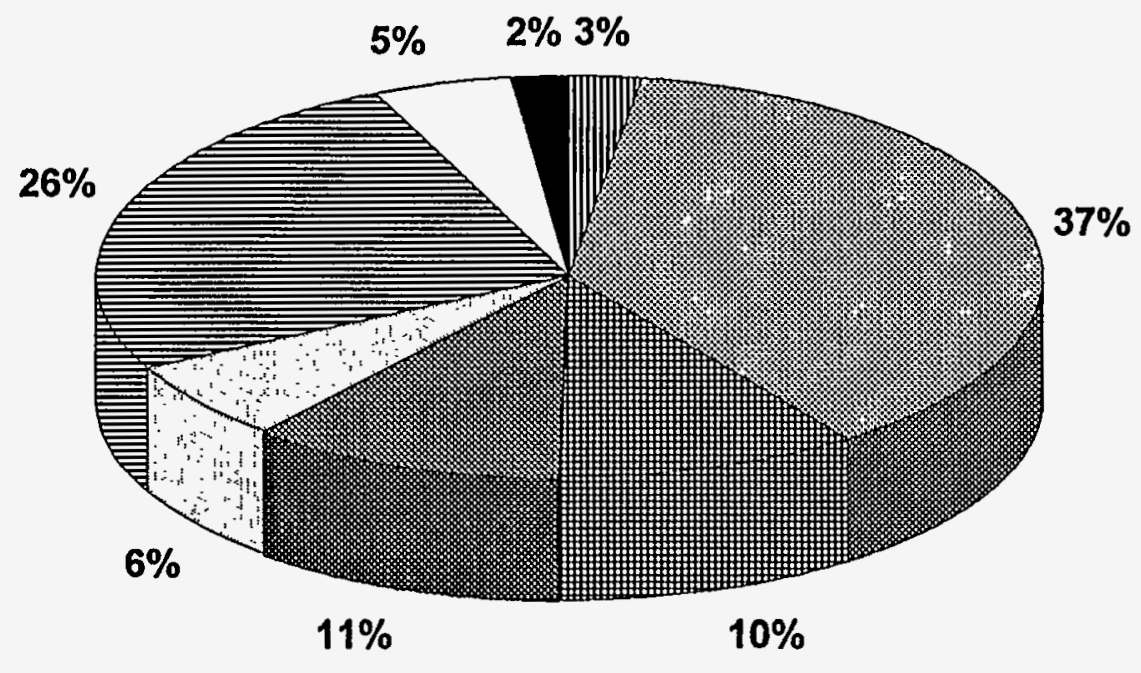

* Does not include mass due to containers.

"Other" consists of Aqueous Organics, Aqueous Cyanide, Soil/Dirt, and Bulk Cadmium.

Information obtained from the DOE/NBM-1100 (MWIR Report), April 1993. 


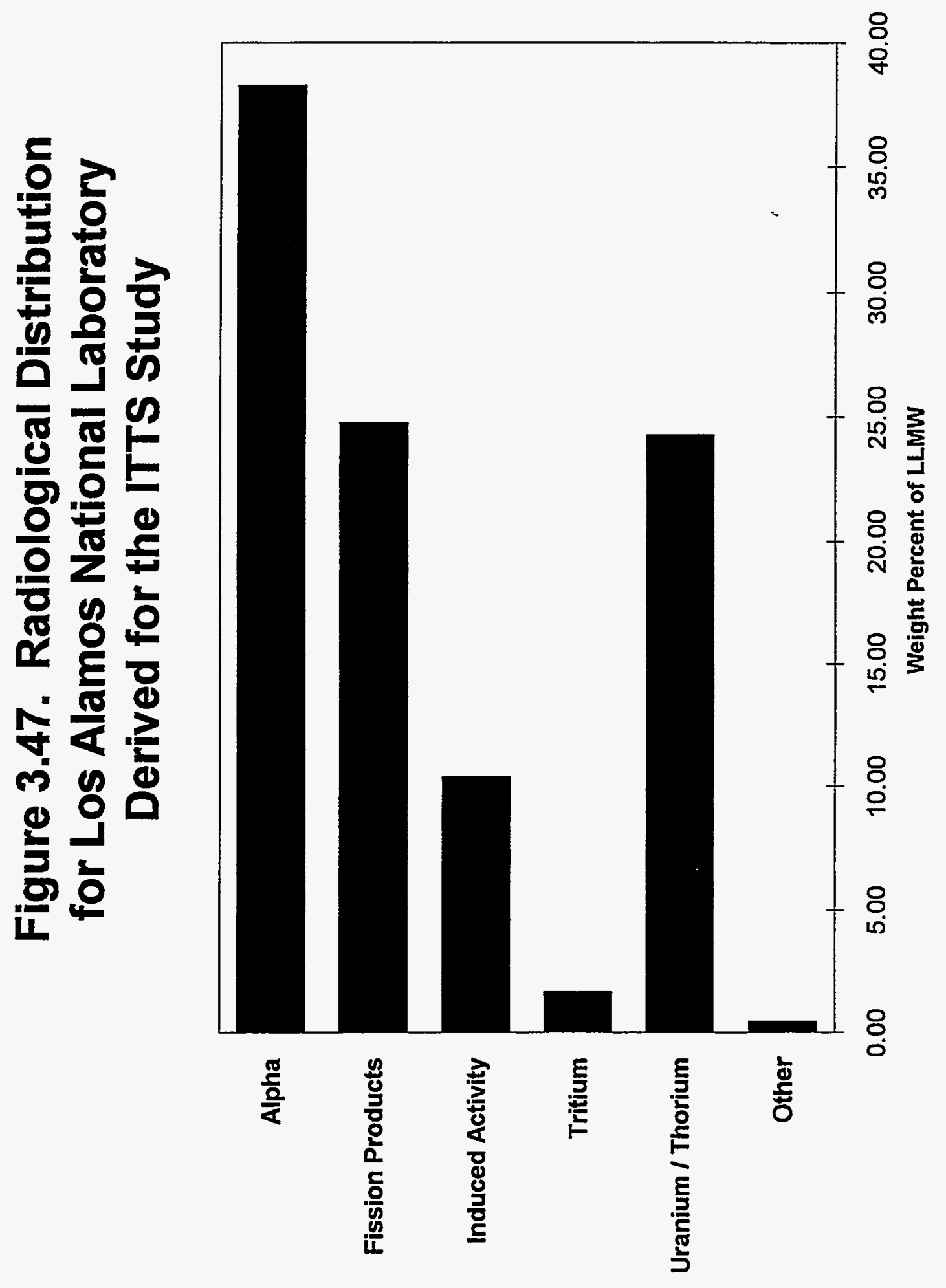

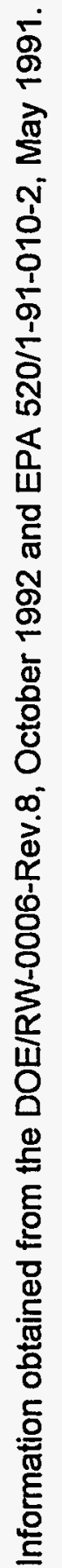




\section{Figure 3.48. Physical Matrix Distribution for Middlesex Sampling Plant Derived for the ITTS Study*}

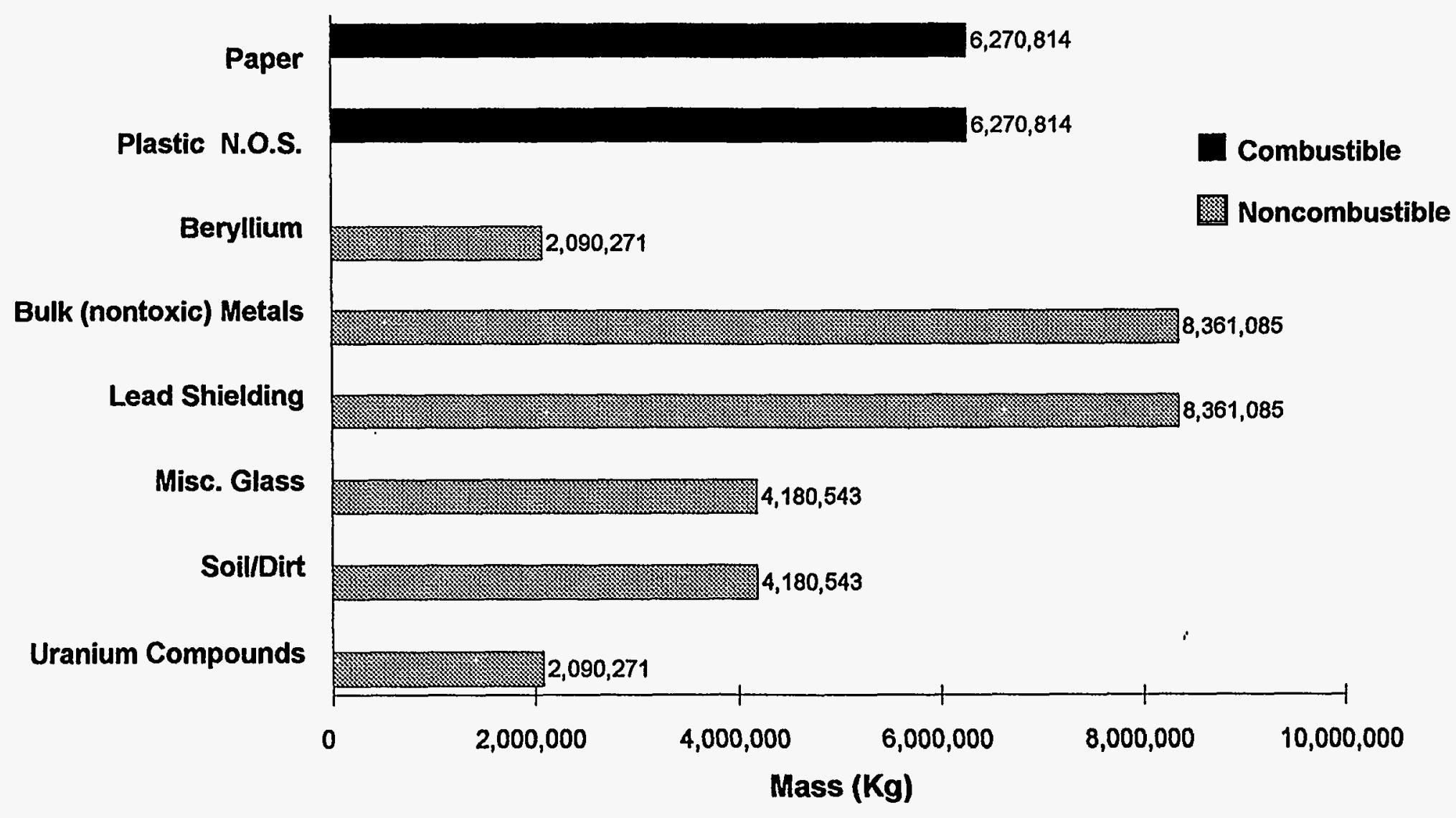

* Does not include mass due to containers.

Information obtained from the DOE/NBM-1100 (MWIR Report), April 1993. 


\section{Figure 3.49. Combustible vs Noncombustible for Middlesex Sampling Plant Derived for the ITTS Study (TOTAL $=41,805,426 \mathrm{Kg})^{*}$}

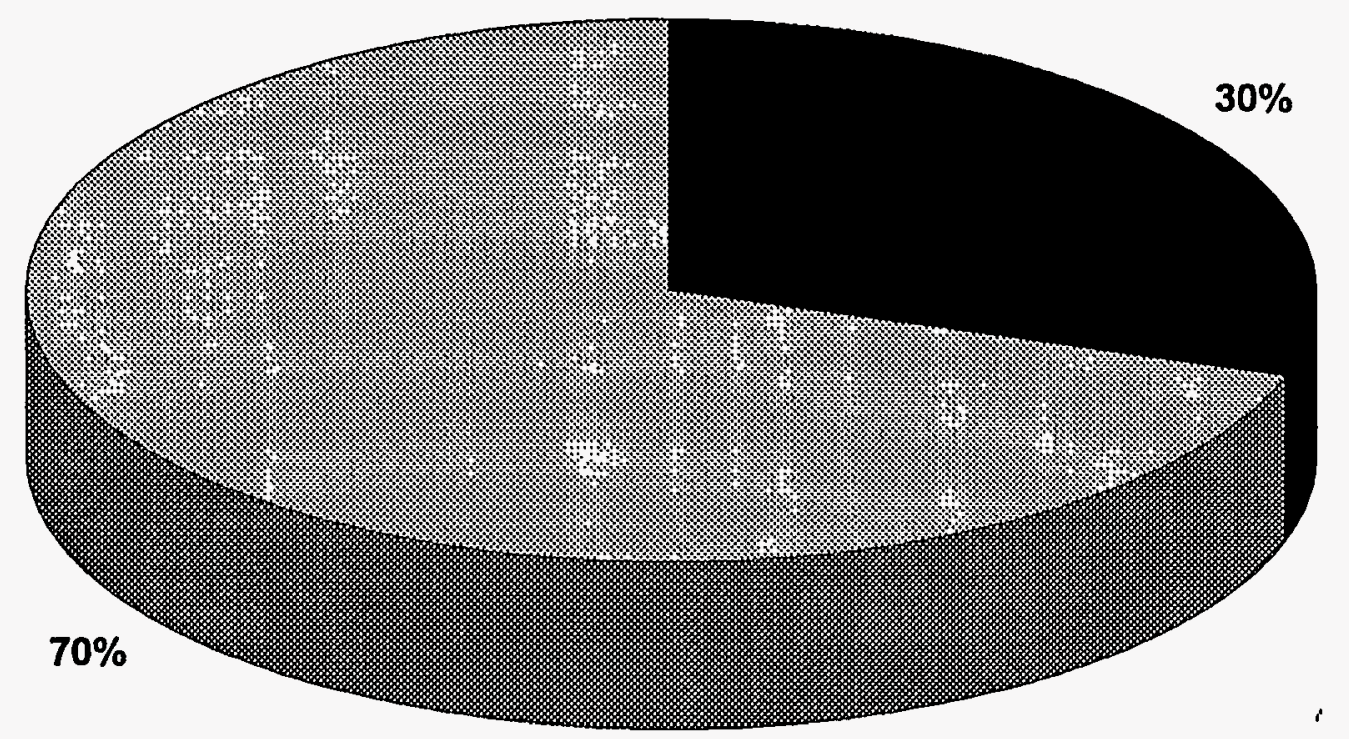

Combustible Noncombustible 


\section{Figure 3.50. Combustible Physical Matrix Distribution for Middlesex Sampling Plant Derived for the ITTS Study (Combustibles $=12,541,628 \mathrm{Kg}$ )}

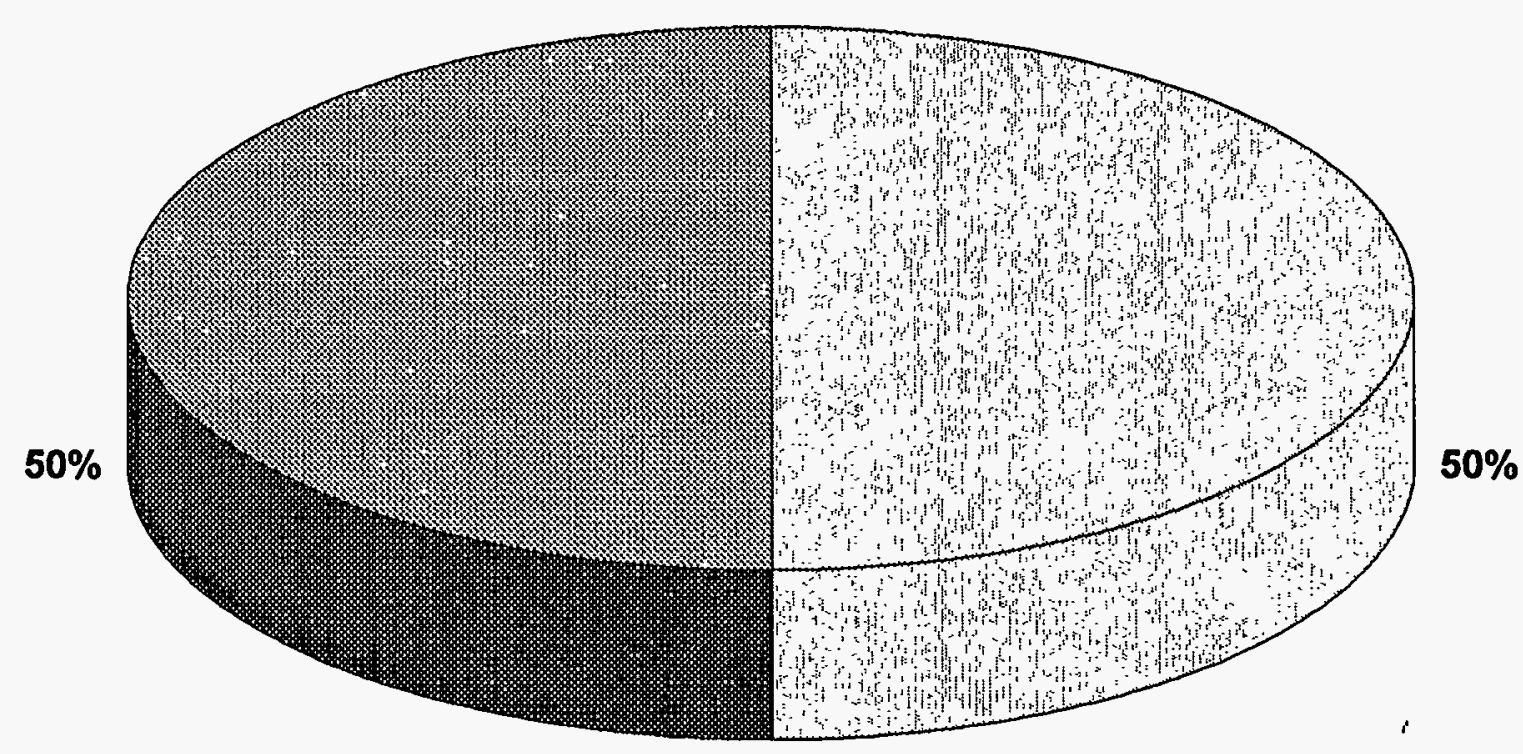

$\square$ Plastic N.O.S. Paper

* Does not include mass due to containers.

Information obtained from the DOE/NBM-1100 (MWIR Report), April 1993. 


\section{Figure 3.51. Noncombustible Physical Matrix Distribution for Middlesex Sampling Plant Derived for the ITTS Study (Noncombustible $=29,263,798 \mathrm{Kg}$ )}
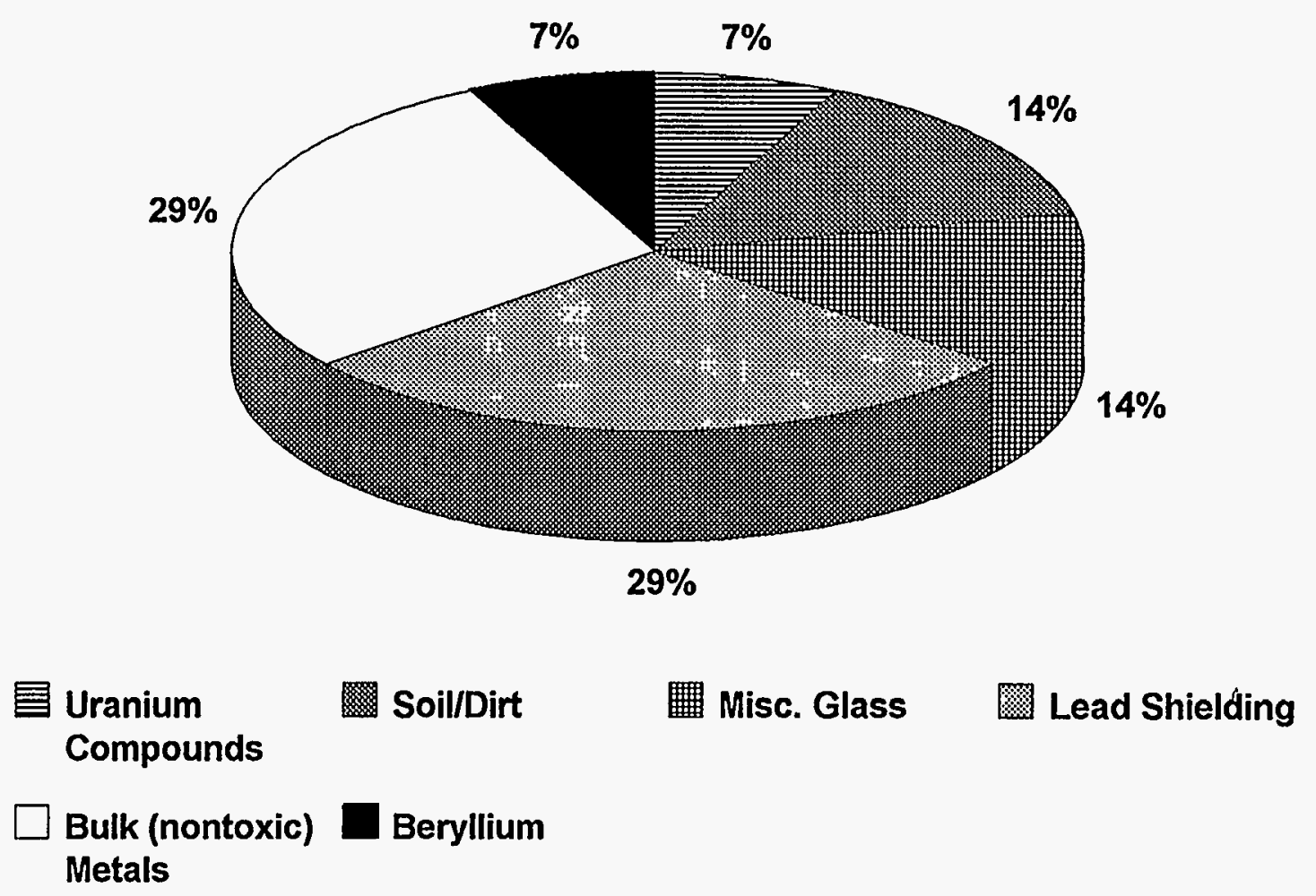


\section{Figure 3.52. Radiological Distribution for Middlesex Sampling Plant Derived for the ITTS Study}

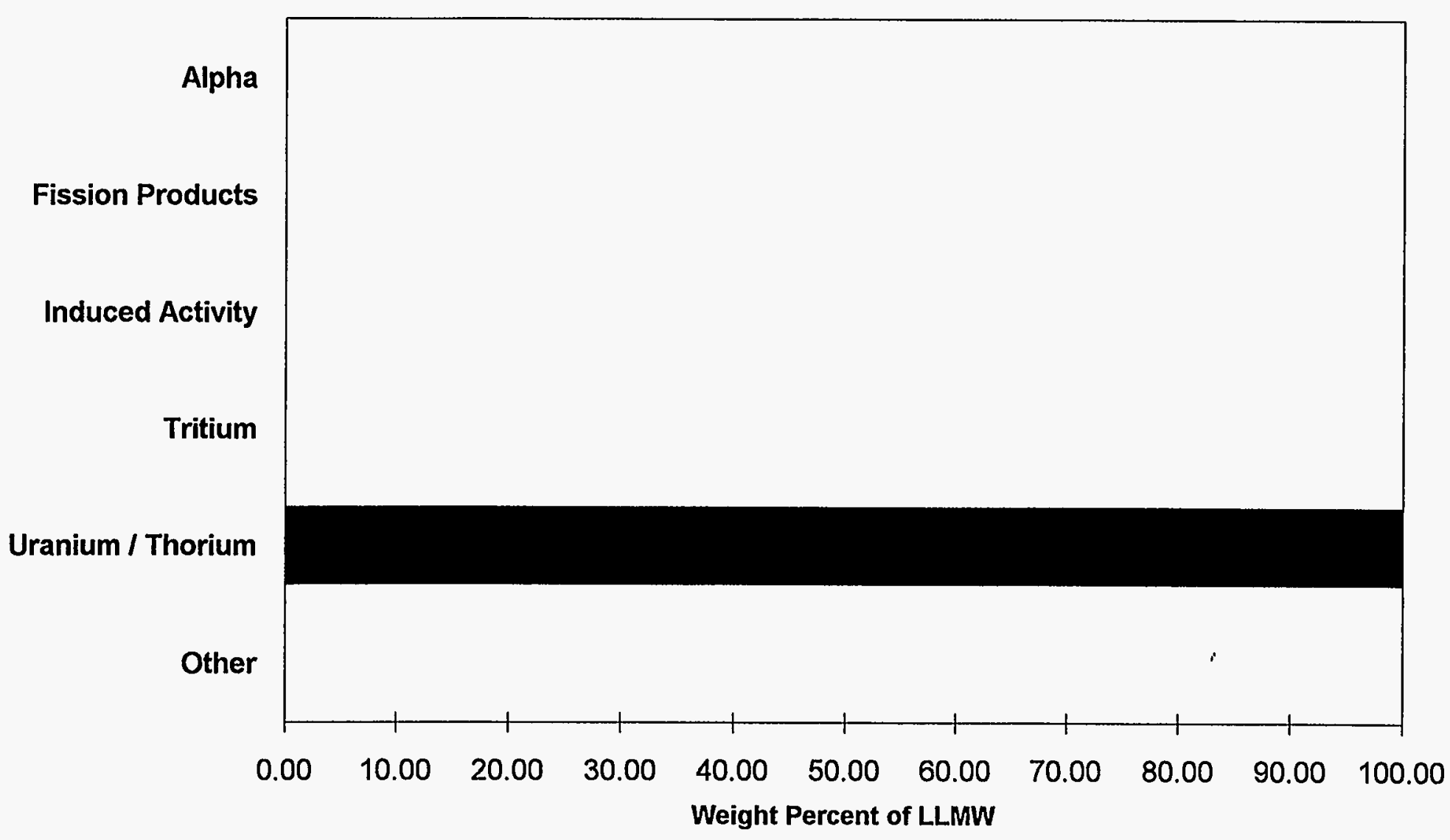

Information obtained from the DOE/NBM-1100 (MWIR Report), April 1993. 


\section{Figure 3.53. Physical Matrix Distribution for Oak Ridge National Laboratory Derived for the ITTS Study*}

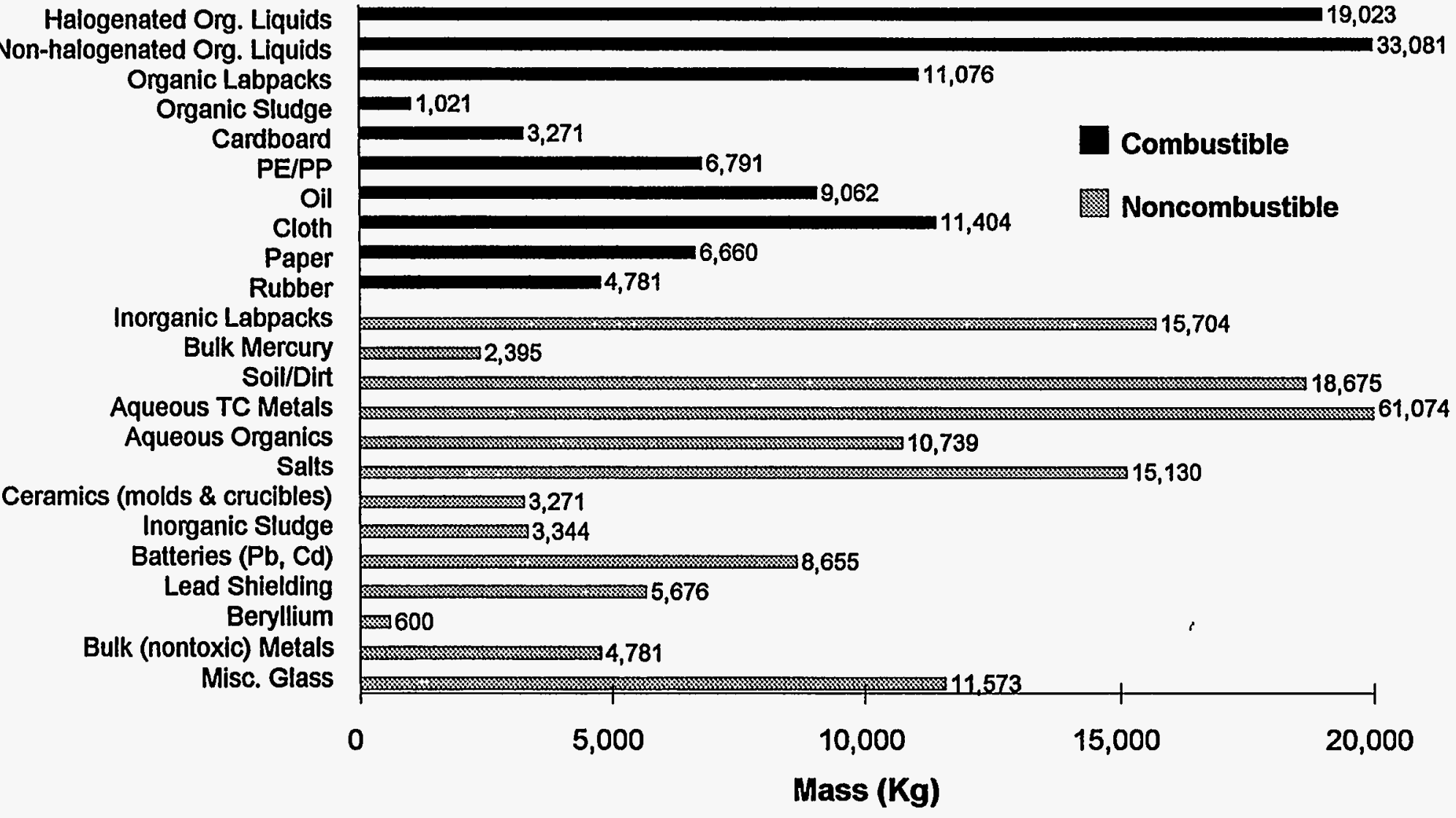

* Does not include mass due to containers.

Information obtained from the DOE/NBM-1100 (MWIR Report), April 1993. 


\section{Figure 3.54. Combustible vs Noncombustible for Oak Ridge National Laboratory Derived for the ITTS Study (TOTAL=267,789 Kg)*}

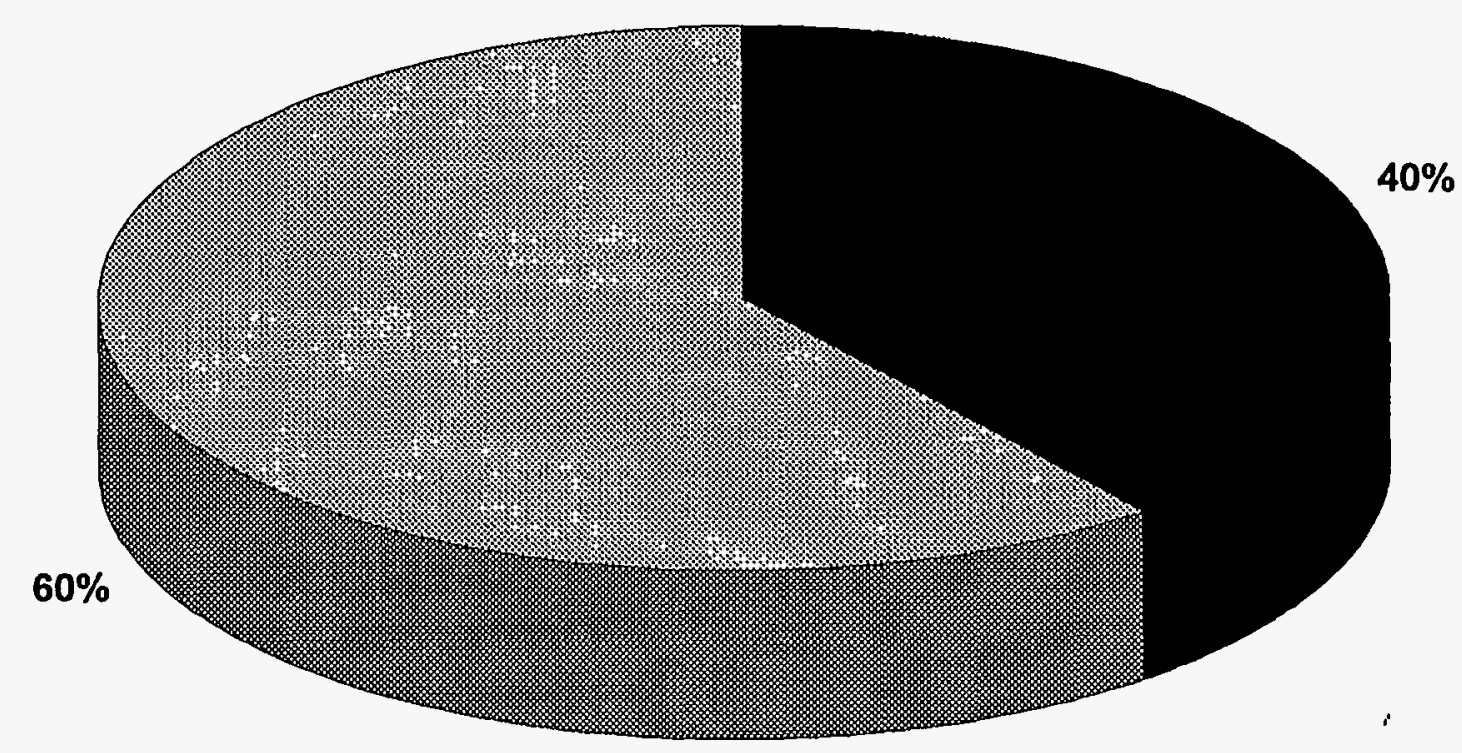

Combustible

Noncombustible

* Does not include mass due to containers.

Information obtained from the DOE/NBM-1100 (MWIR Report), April 1993. 


\section{Figure 3.55. Combustible Physical Matrix Distribution for Oak Ridge National Laboratory Derived for the ITTS Study (Combustibles $=106,171 \mathrm{Kg})^{*}$}

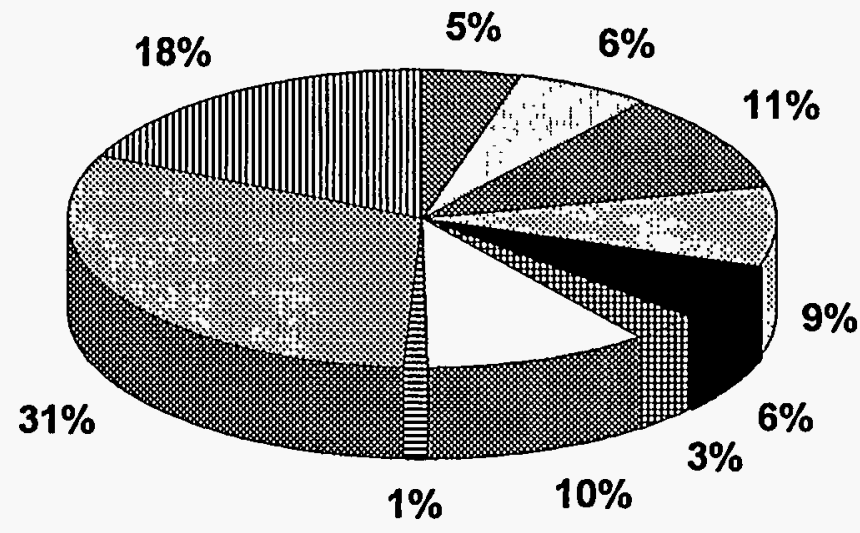

\begin{tabular}{|c|c|c|c|}
\hline Rubber & Paper & Cloth & 0 \\
\hline PEIPP & 典 Cardboard & $\begin{array}{l}\square \text { Organic } \\
\text { Labpacks }\end{array}$ & 置 Organic Sludge \\
\hline
\end{tabular}




\section{Figure 3.56. Noncombustible Physical Matrix Distribution for Oak Ridge National Laboratory Derived for the ITTS Study (Noncombustibles $=161,618 \mathrm{Kg})^{*}$}

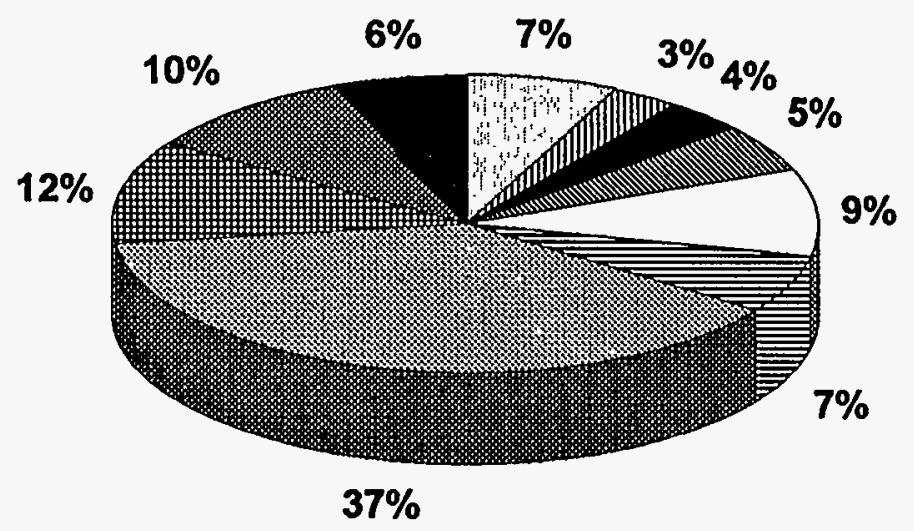

\begin{tabular}{llll}
\hline Misc. Glass & $\begin{array}{l}\text { Bulk (nontoxic) } \\
\text { Metals }\end{array}$ & Lead Shielding & Batteries (Pb, Cd) \\
$\square$ Salts & $\begin{array}{l}\text { Aqueous } \\
\text { Organics }\end{array}$ & $\begin{array}{c}\text { Aqueous TC } \\
\text { Metals }\end{array}$ & Soil/Dirt ' \\
$\begin{array}{l}\text { Inorganic } \\
\text { Labpacks }\end{array}$ & Other &
\end{tabular}

* Does not include mass due to containers.

"Other" consists of Bulk Mercury, Beryllium, Inorganic Sludge, and Ceramics.

Information obtained from the DOE/NBM-1100 (MWIR Report), April 1993. 


\section{Figure 3.57. Radiological Distribution for Oak Ridge National Laboratory Derived for the ITTS Study}

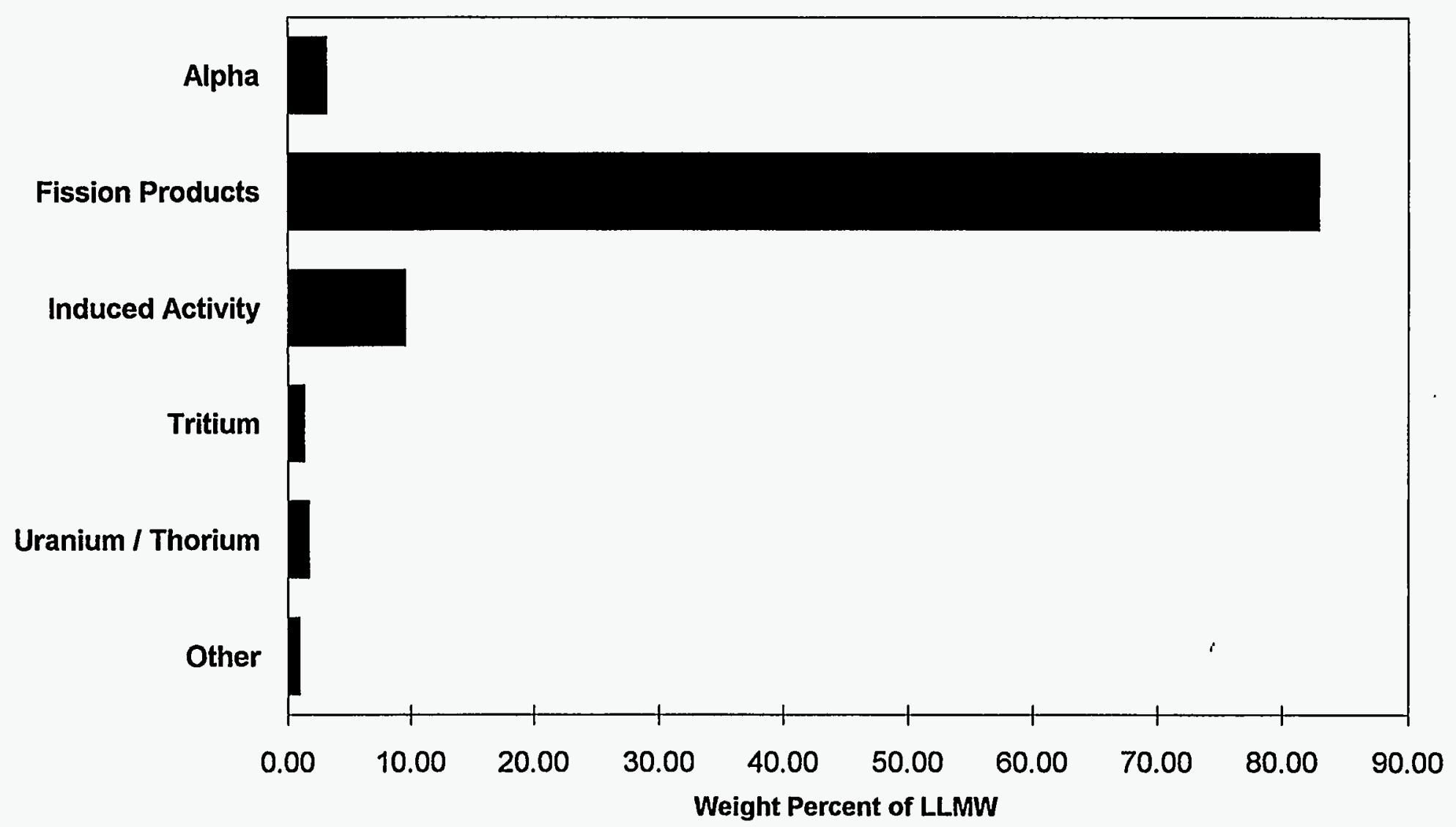




\section{Figure 3.58. Physical Matrix Distribution for Oak Ridge National Laboratory, K-25 Site Derived for the ITTS Study*}

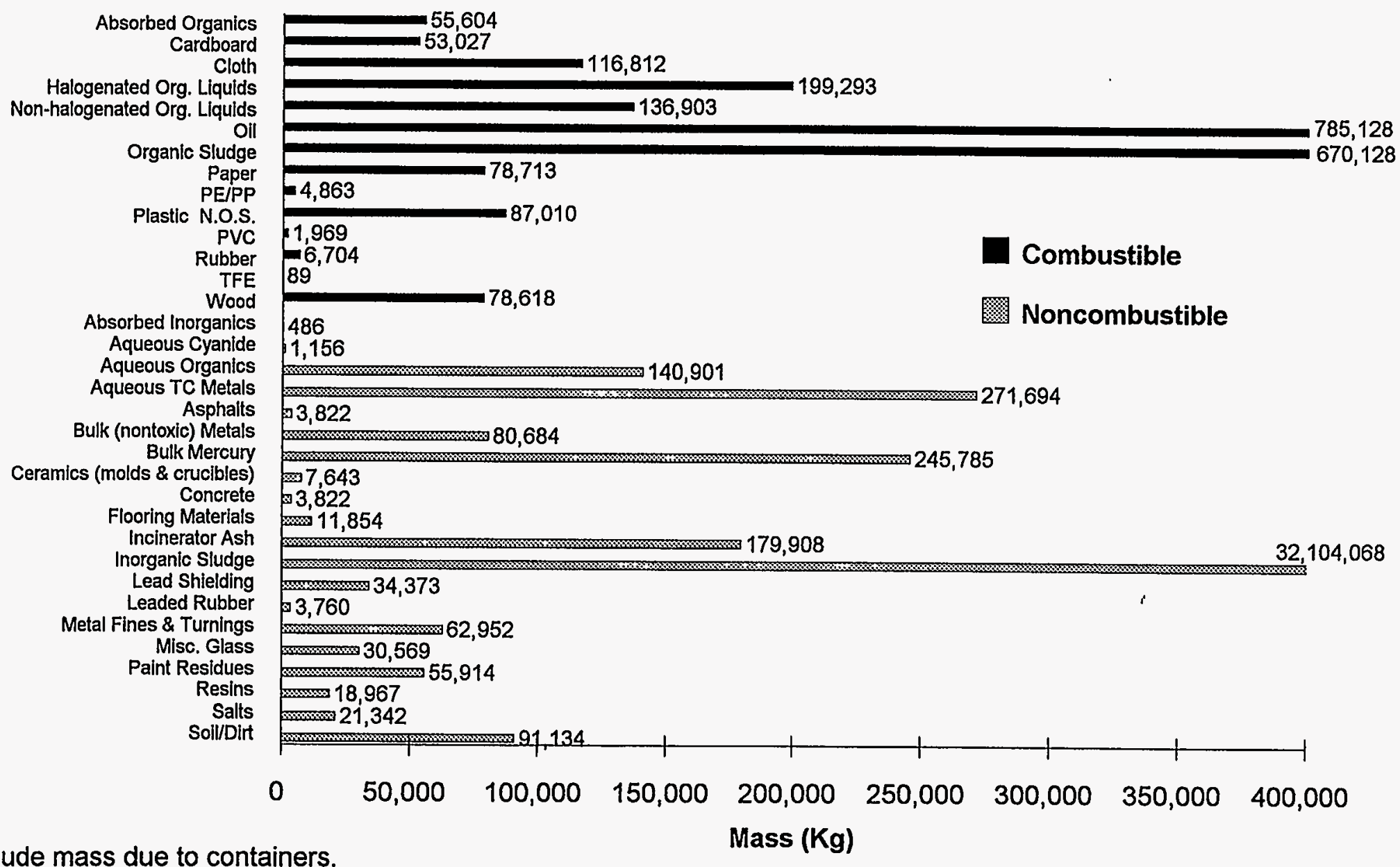

* Does not include mass due to containers.

Information obtained from the DOE/NBM-1100, April 1993. 


\section{Figure 3.59. Combustible vs Noncombustible for Oak Ridge National Laboratory, K-25 Site Derived for the ITTS Study (TOTAL $=35,645,796 \mathrm{Kg}$ )}

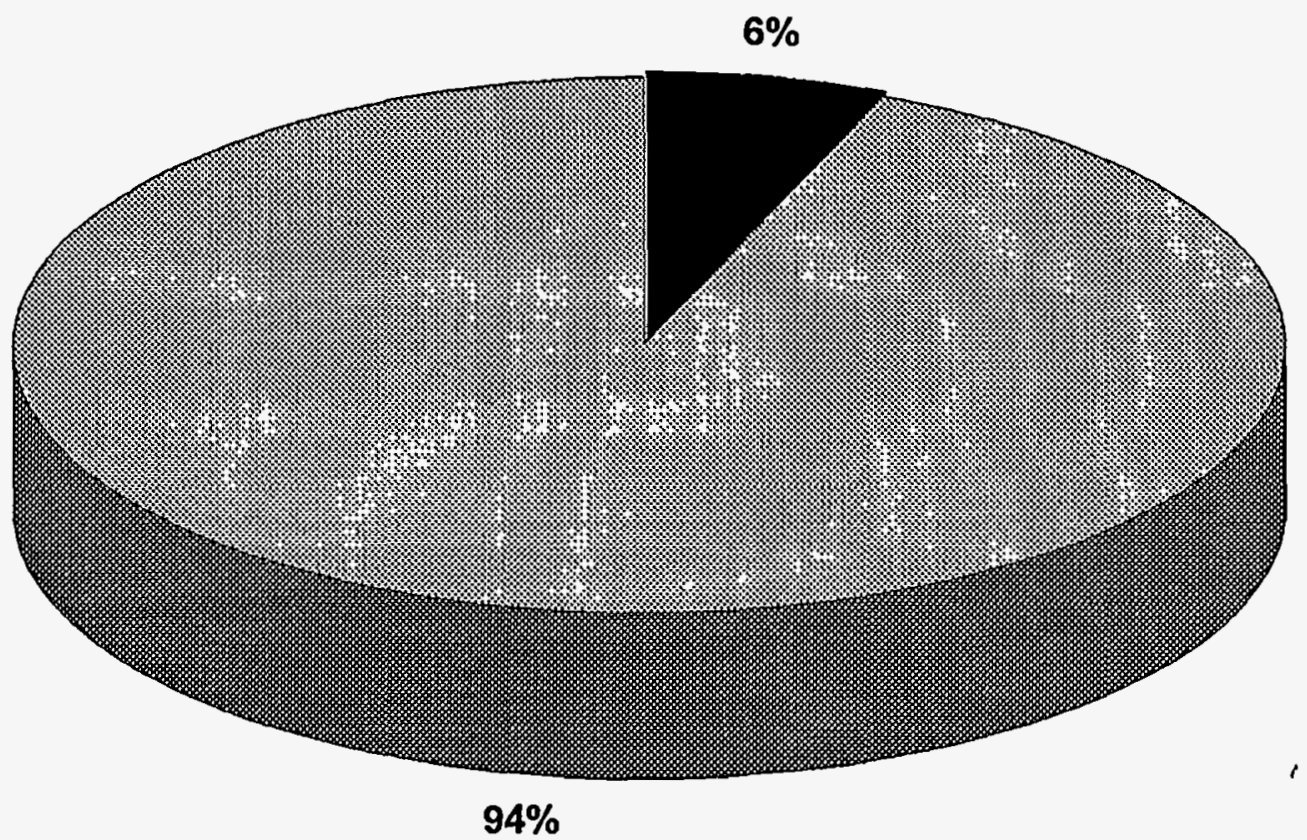

Combustible Noncombustible 


\section{Figure 3.60. Combustible Physical Matrix Distribution for Oak Ridge National Laboratory, K-25 Site Derived for the ITTS Study (Combustibles=2,274,963 Kg)*}

\begin{tabular}{|c|c|c|}
\hline$\square$ Wood & 冒 Plastic & Paper \\
\hline Organic Sludge & Oil & $\begin{array}{l}\text { Non-halogenated } \\
\text { Org. Liquids }\end{array}$ \\
\hline $\begin{array}{l}\text { Halogenated Org. } \\
\text { Liquids }\end{array}$ & Cloth & Other \\
\hline
\end{tabular}

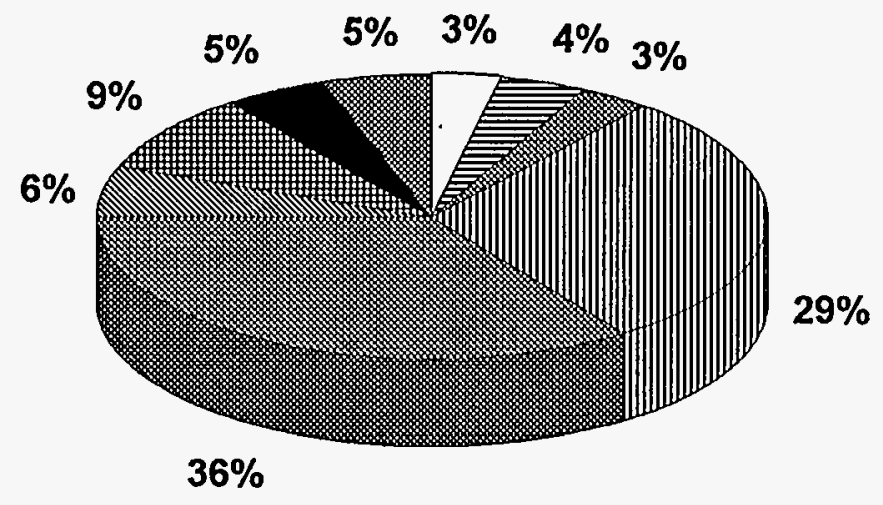

* Does not include mass due to containers.

"Other" consists of Rubber, Cardboard, and Absorbed Organics.

Information obtained from the DOE/NBM-1100, April 1993. 


\section{Figure 3.61. Noncombustible Physical Matrix Distribution for Oak Ridge National Laboratory, K-25 Site Derived for the ITTS Study (Noncombustibles $=33,370,832 \mathrm{Kg}$ )}

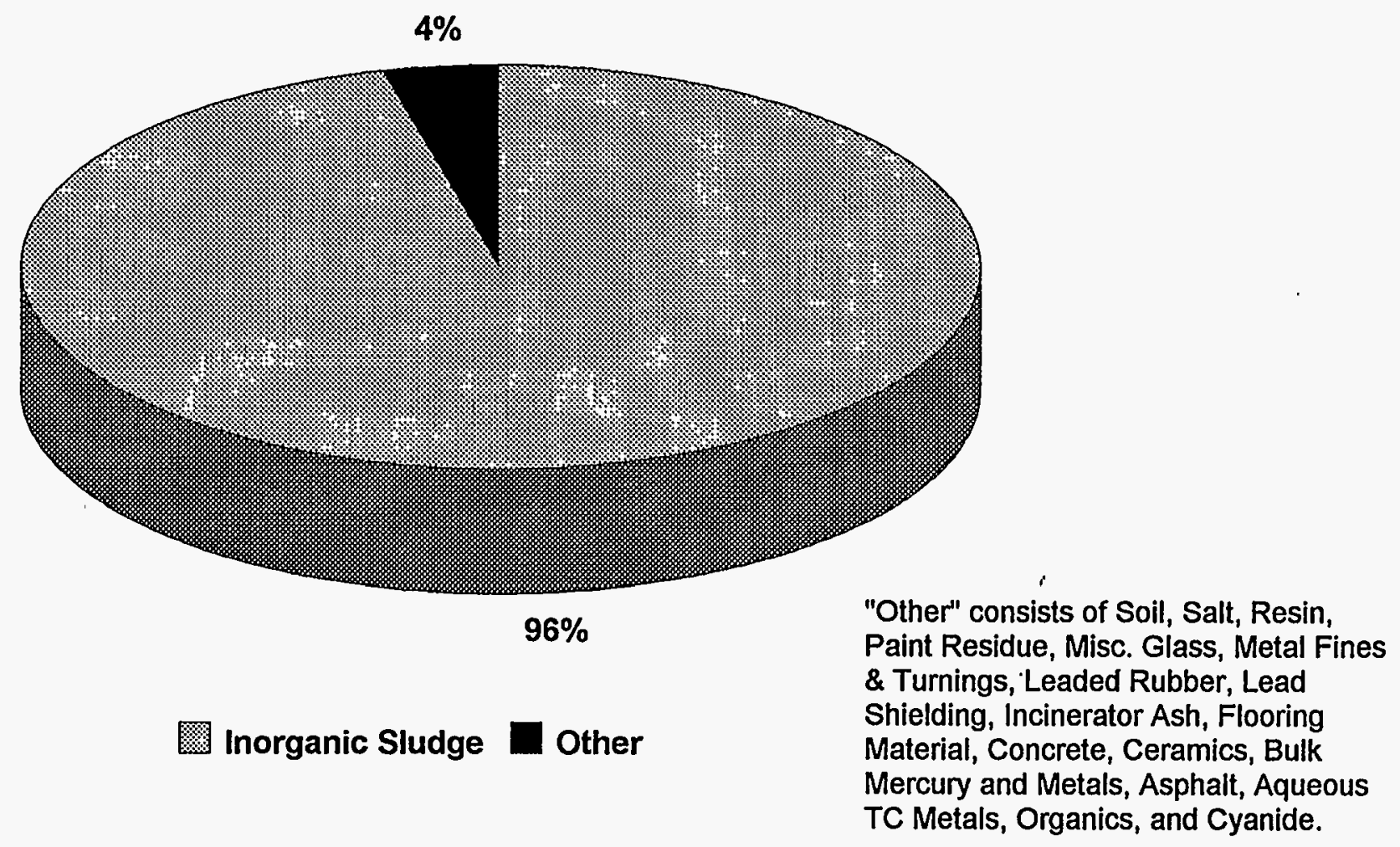

* Does not include mass due to containers.

Information obtained from the DOE/NBM-1100, April 1993. 


\section{Figure 3.62. Radiological Distribution for Oak Ridge National Laboratory, K-25 Site Derived for the ITTS Study}

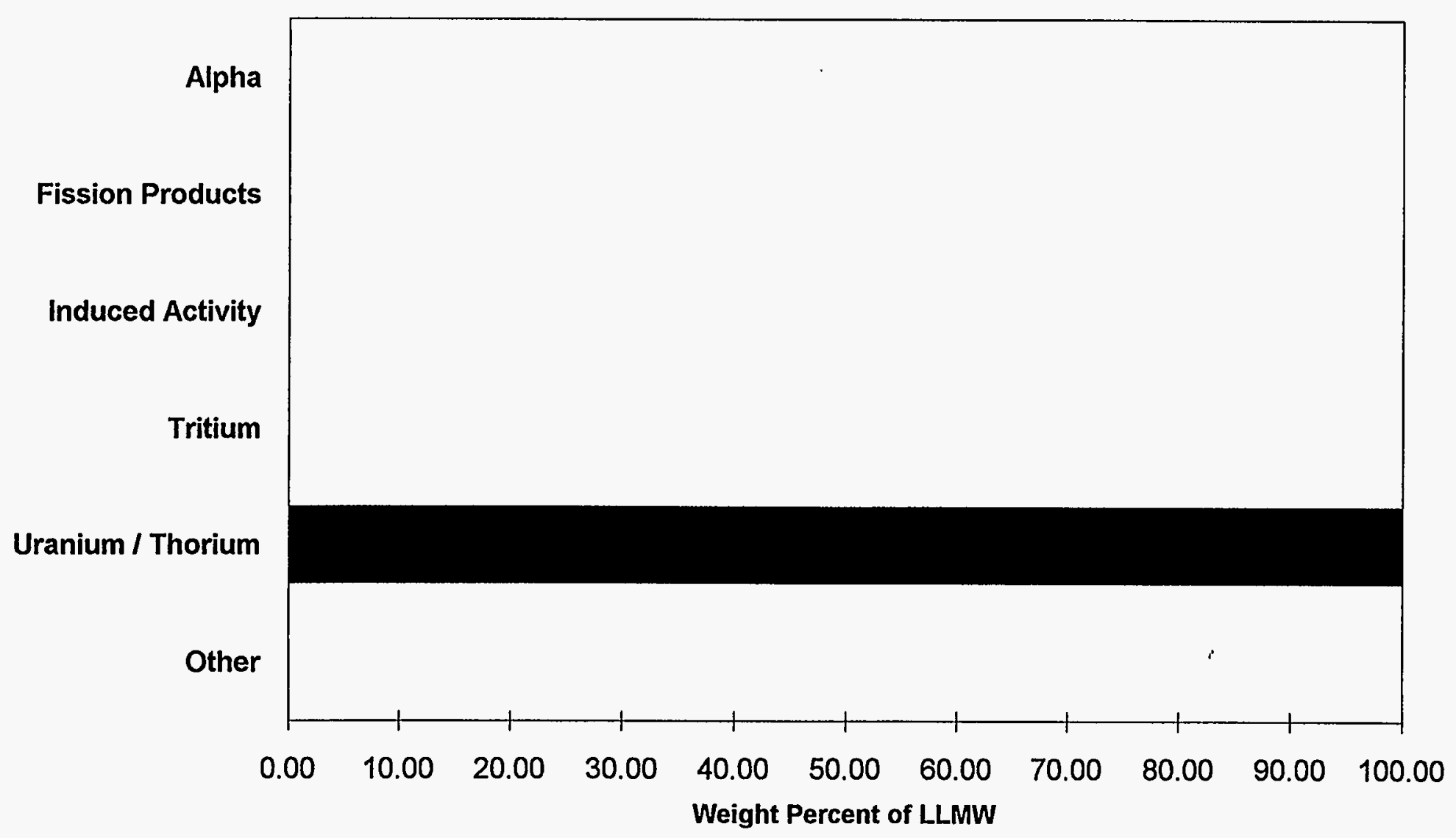

Information obtained from DOEIRW-0006-Rev. 8, October 1992 and EPA-520/1-91-010-2, May 1991. 


\section{Figure 3.63. Physical Matrix Distribution for Oak Ridge National Laboratory, Y-12 Plant Derived for the ITTS Study*}

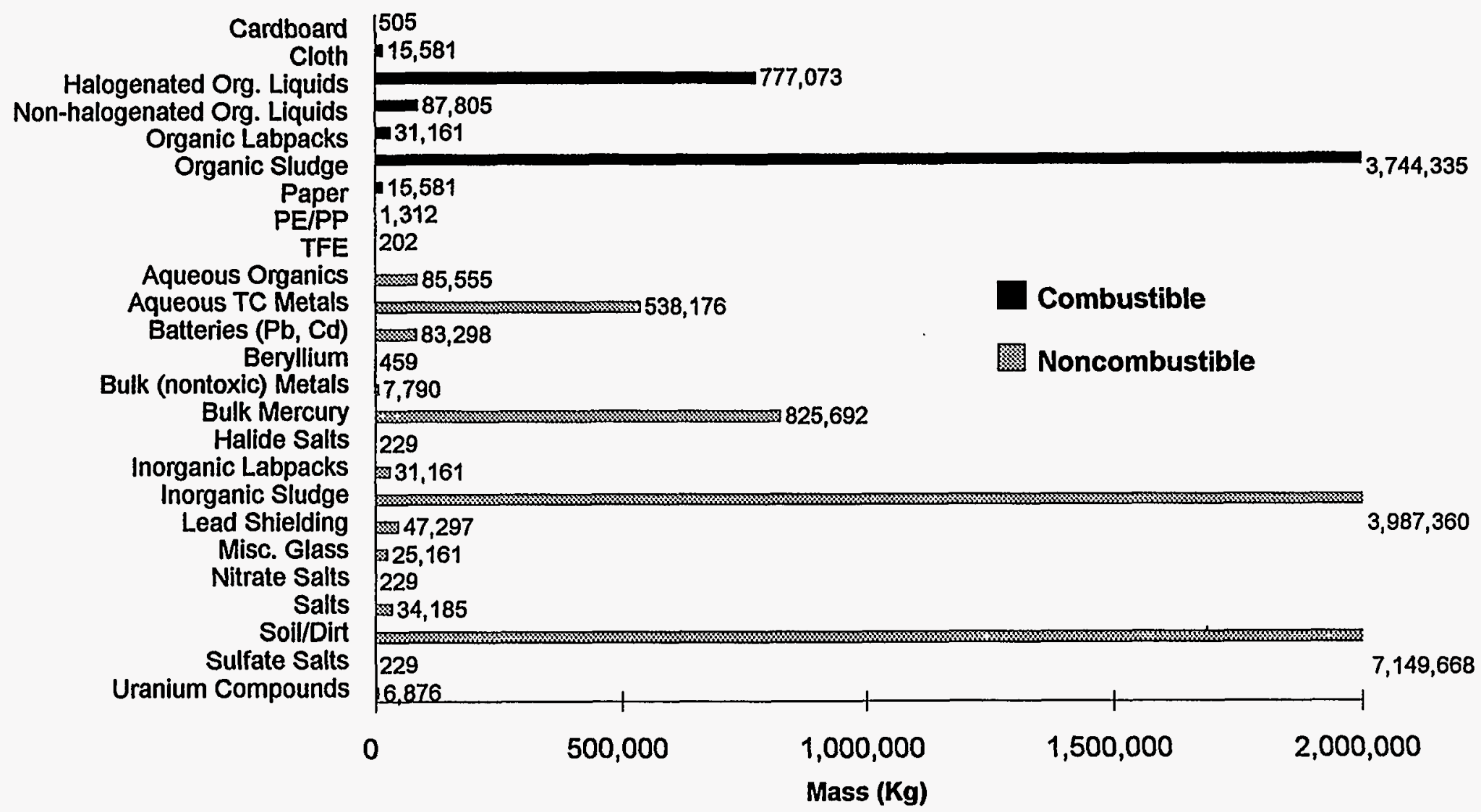

* Does not include mass due to containers.

Information obtained from the DOE/NBM-1100 (MWIR Report), April 1993. 


\section{Figure 3.64. Combustible vs Noncombustible for Oak Ridge National Laboratory, Y-12 Plant Derived for the ITTS Study (TOTAL=17,496,920 Kg)*}

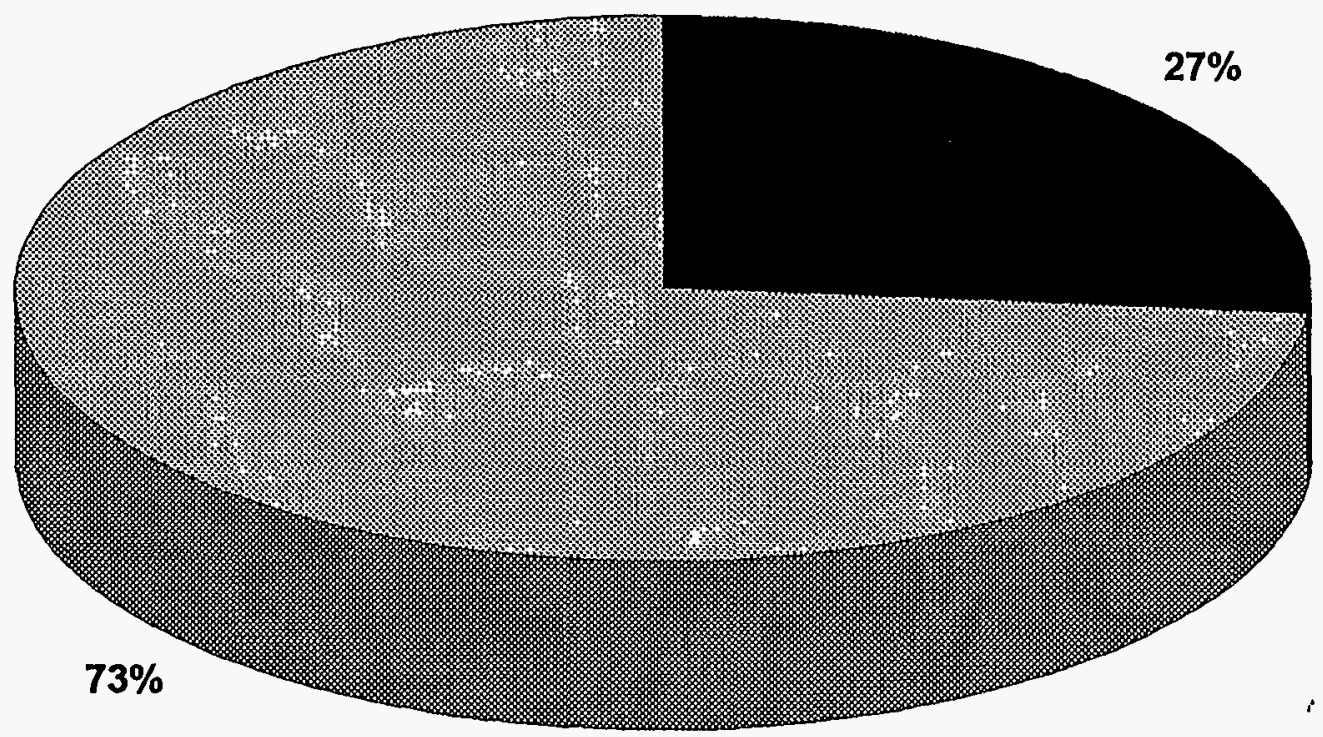

Combustible Noncombustible

* Does not include mass due to containers.

Information obtained from the DOE/NBM-1100 (MWIR Report), April 1993. 


\section{Figure 3.65. Combustible Physical Distribution for Oak Ridge National Laboratory, Y-12 Plant Derived for the ITTS Study (Combustibles=4,673,555 Kg)*}

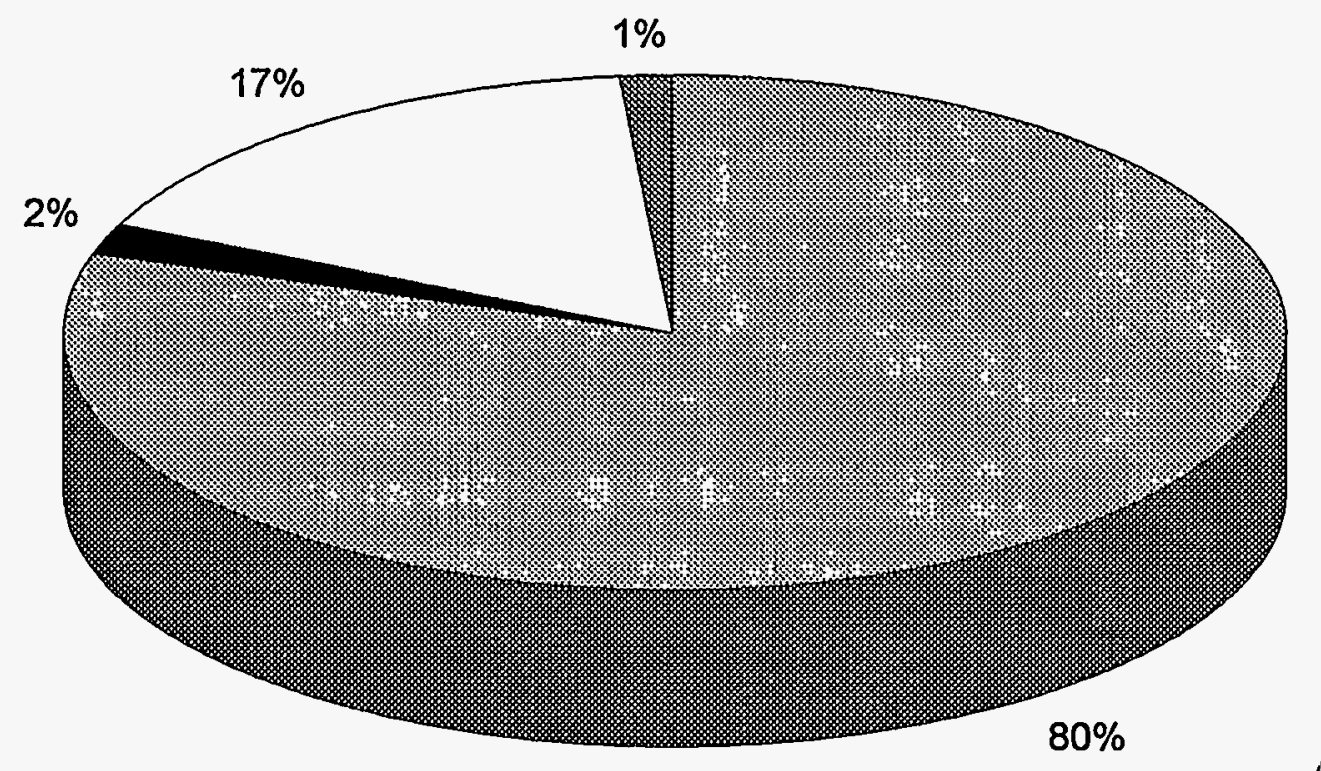

$$
\text { Organic Sludge } \square \begin{aligned}
& \text { Non-halogenated Org. } \\
& \text { Liquids }
\end{aligned} \text { Halogenated Org. }
$$

* Does not include mass due to containers.

"Other" consists of Cloth, Paper, Plastics, Organic Labpacks, and Cardboard.

Information obtained from the DOE/NBM-1100 (MWIR Report), April 1993. 


\section{Figure 3.66. Noncombustible Physical Matrix Distribution for Oak Ridge National Laboratory, Y-12 Plant Derived for the ITTS Study (Noncombustibles=12,823,365 Kg)*}
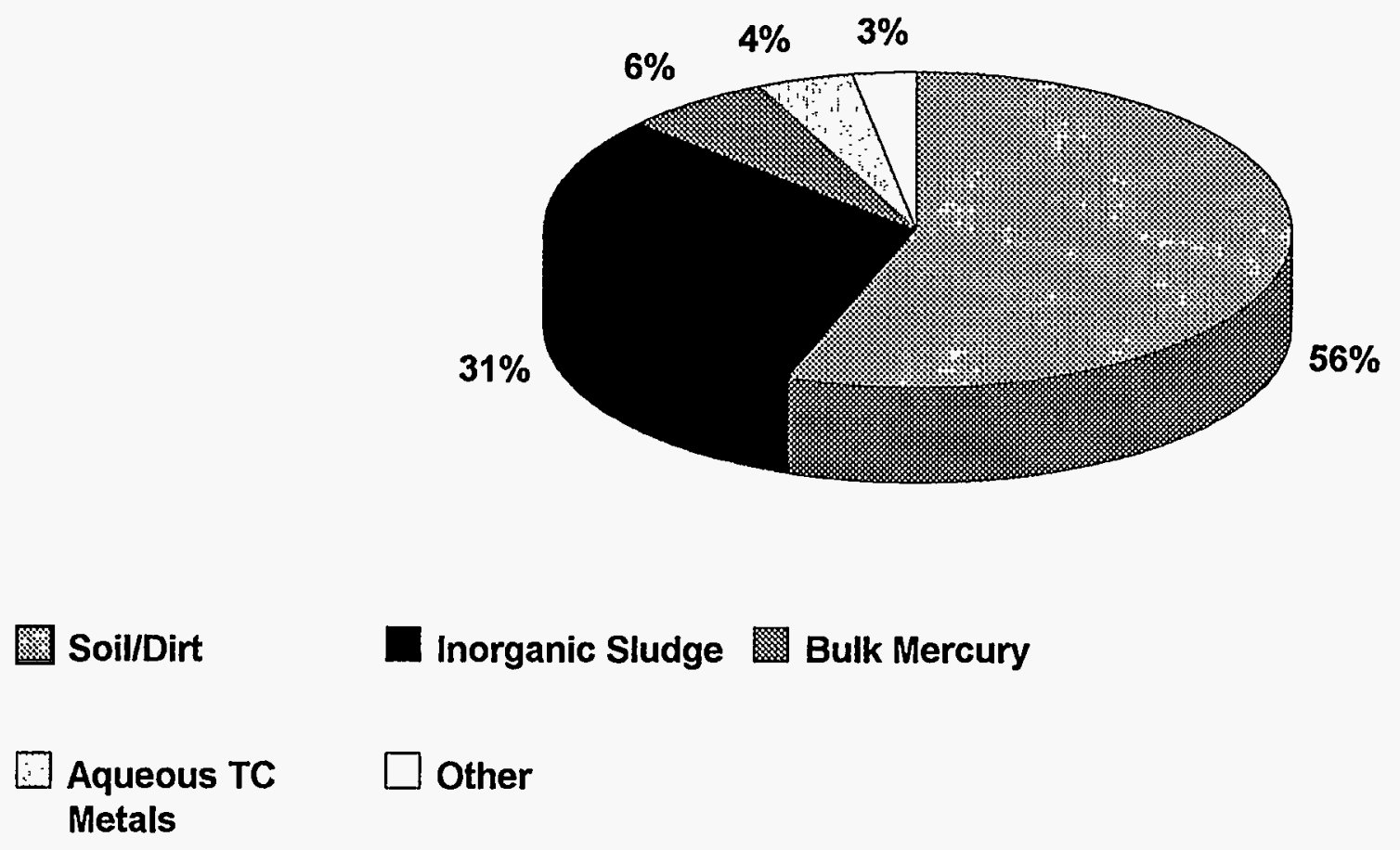


\section{Figure 3.67. Radiological Distribution for Oak Ridge National Laboratory, Y-12 Plant Derived for the ITTS Study}

$\overrightarrow{\mathrm{w}}$

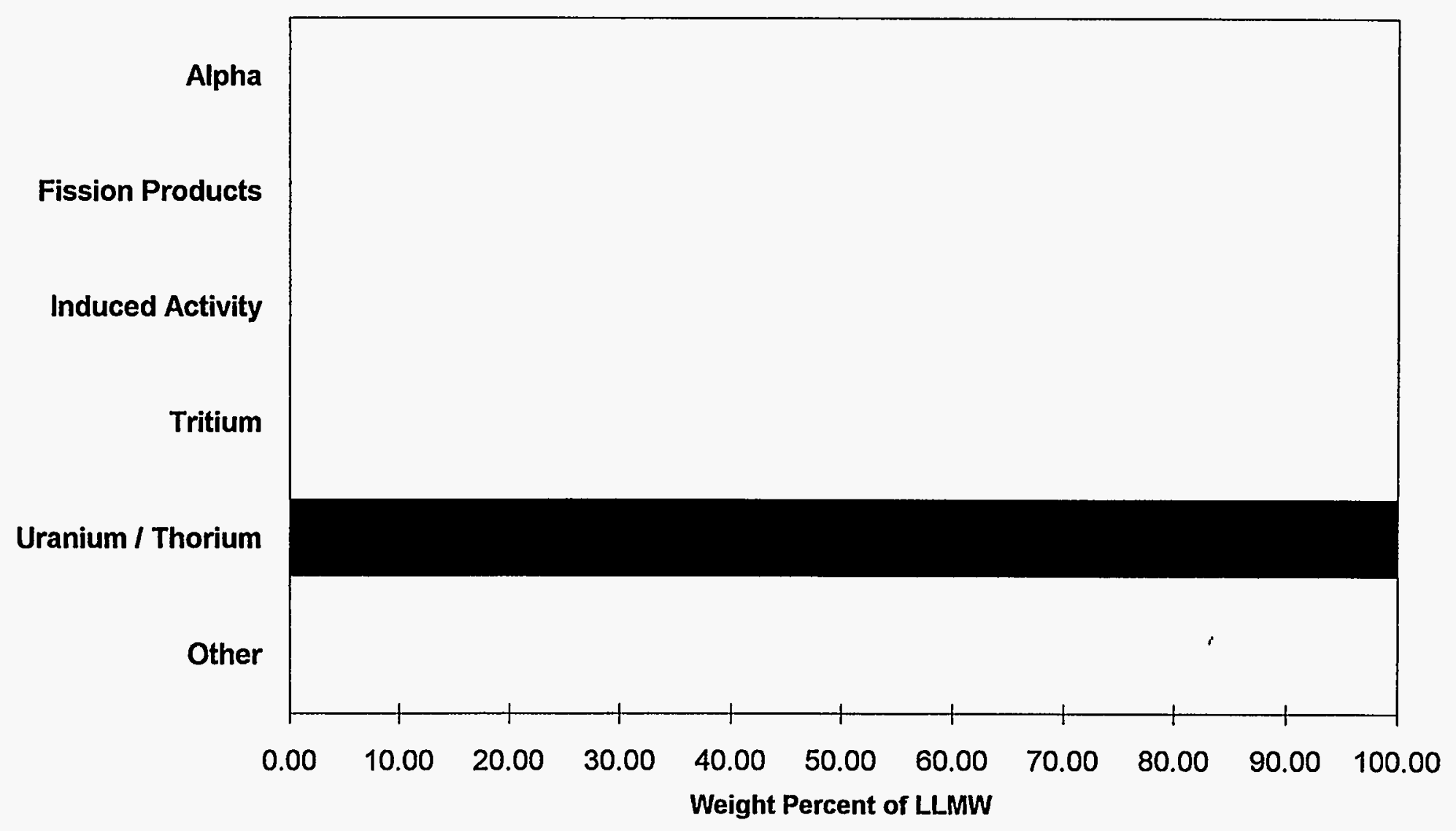




\section{Figure 3.68. Physical Matrix Distribution for Paducah Gaseous Diffusion Plant Derived for the ITTS Study*}

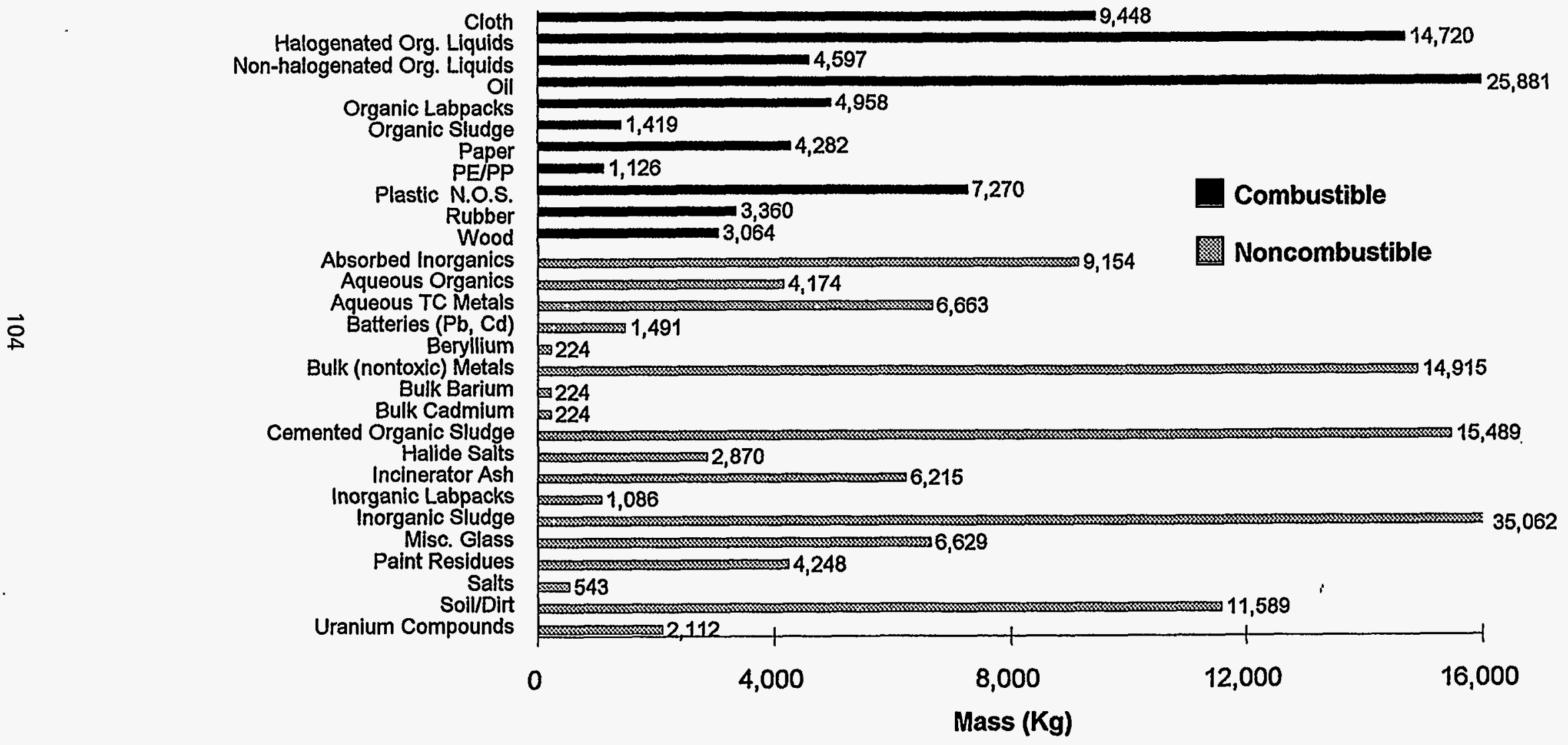

* Does not include mass due to containers.

Information obtained from the DOE/NBM-1100 (MWIR Report), April 1993. 


\section{Figure 3.69. Combustible vs Noncombustible for Paducah Gaseous Diffusion Plant Derived for the ITTS Study (TOTAL=203,037 Kg)*}

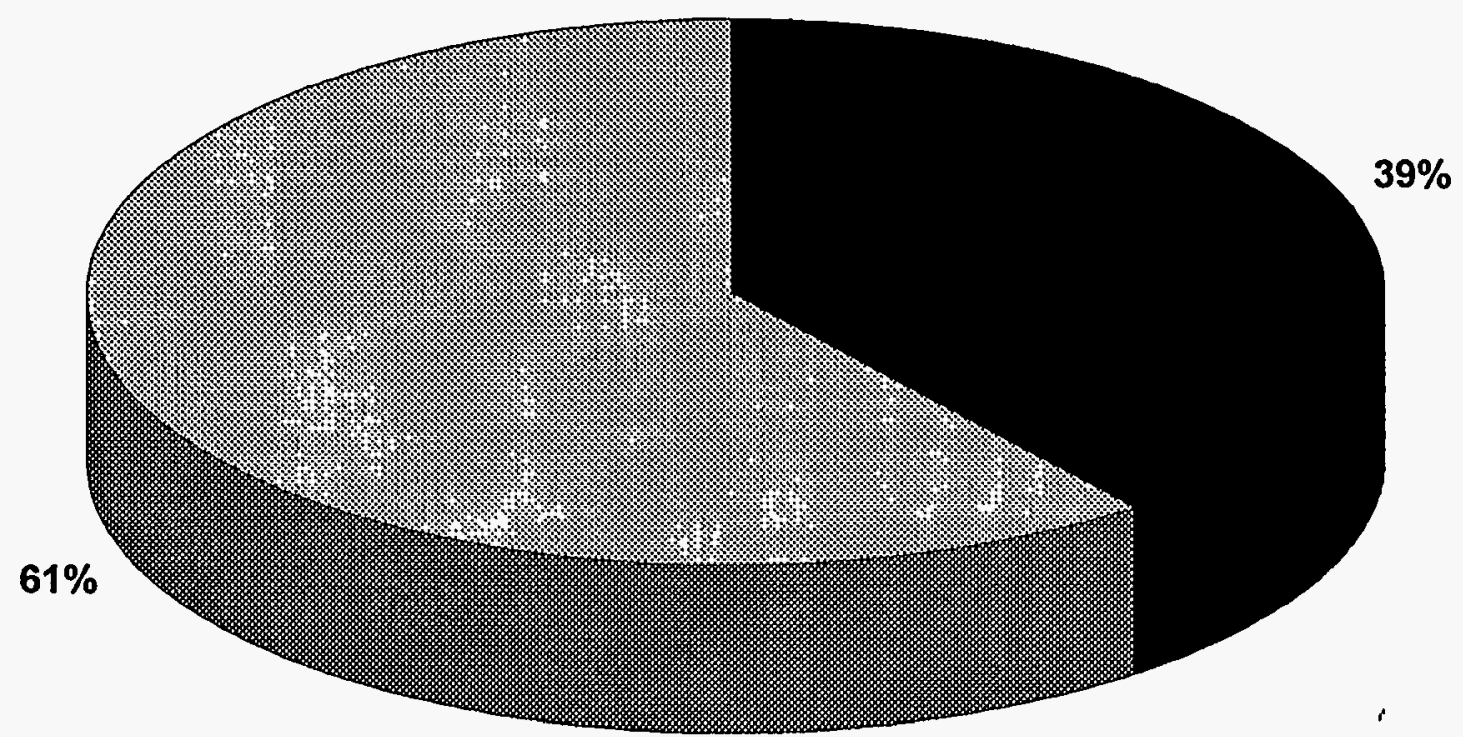

Combustible Noncombustible

* Does not include mass due to containers.

Information obtained from the DOE/NBM-1100 (MWIR Report), April 1993. 


\section{Figure 3.70. Combustible Physical Matrix Distribution for Paducah Gaseous Diffusion Plant Derived for the ITTS Study (Combustibles $=80,127 \mathrm{Kg}$ )*}

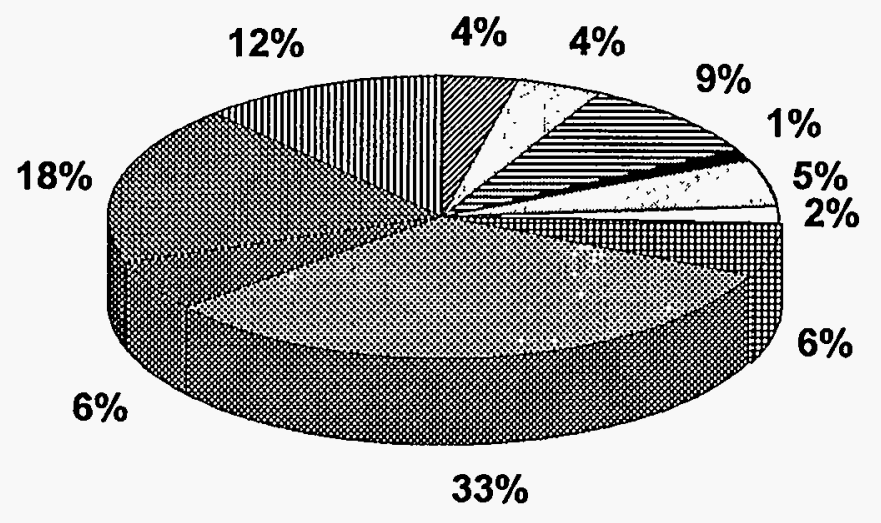

\begin{tabular}{|c|c|c|c|}
\hline Wood & $\square$ Rubber & 呈 Plastic N.O.S. & DE/PP \\
\hline$\square$ Paper & $\square$ Organic Sludge & $\begin{array}{l}\text { 嘈 Organic } \\
\text { Labpacks }\end{array}$ & Oil \\
\hline $\begin{array}{l}\text { Non-halogenated } \\
\text { Org. Liquids }\end{array}$ & $\begin{array}{l}\text { Halogenated Org. } \\
\text { Liquids }\end{array}$ & 盺 Cloth & \\
\hline
\end{tabular}

* Does not include mass due to containers.

Information obtained from the DOE/NBM-1100 (MWIR Report), April 1993. 


\section{Figure 3.71. Noncombustible Physical Matrix Distribution for Paducah Gaseous Diffusion Plant Derived for the ITTS Study (Noncombustibles $=122,910 \mathrm{Kg})^{*}$}

\begin{tabular}{|c|c|c|c|c|}
\hline $\begin{array}{l}\square \text { Uranium } \\
\text { Compounds }\end{array}$ & Soil/Dirt & Paint Residues & Misc. Glass & Inorganic Sludge \\
\hline Incinerator Ash & Halide Salts & $\begin{array}{l}\text { Cemented Organic } \\
\text { Sludge }\end{array}$ & $\begin{array}{l}\text { 专 Bulk (nontoxic) } \\
\text { Metals }\end{array}$ & $\square$ Aqueous TC Metals \\
\hline 血 Aqueous Organics & $\begin{array}{l}\text { Absorbed } \\
\text { Inorganics }\end{array}$ & Dether & & \\
\hline
\end{tabular}

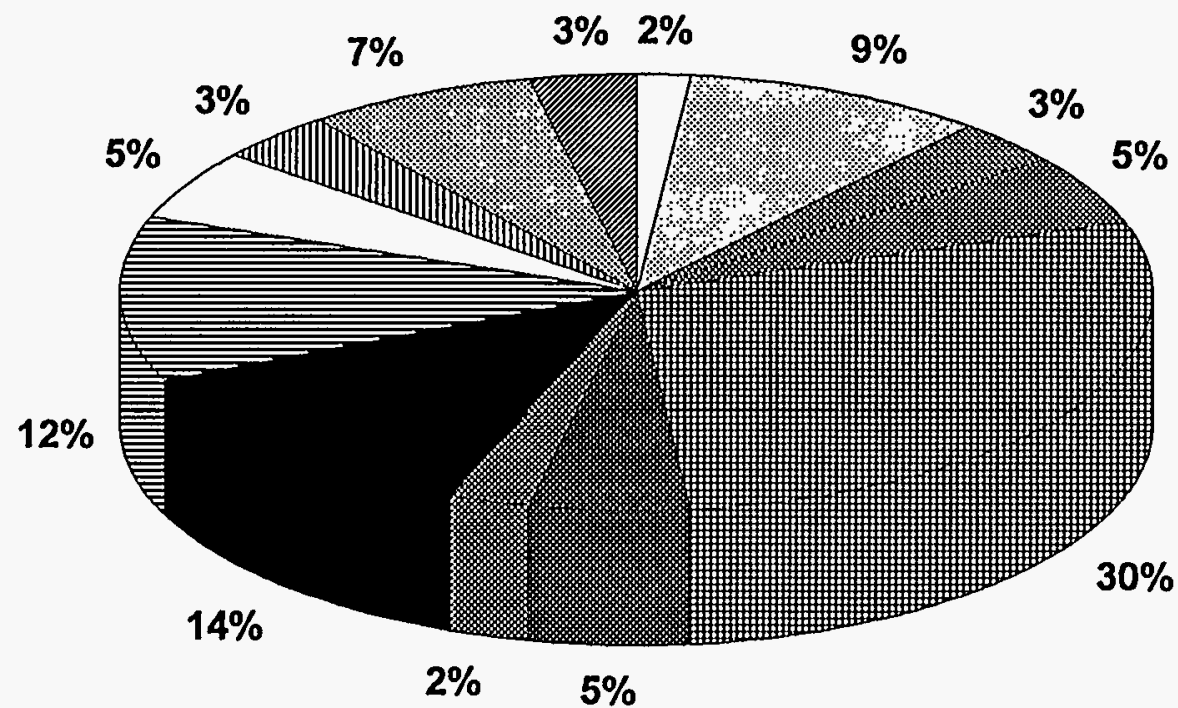

* Does not include mass due to containers.

"Other" consists of Salts, Inorganic Labpacks, Bulk Cadmium and Barium, Beryllium, and Batteries. Information obtained from the DOE/NBM-1100 (MWIR Report), April 1993. 


\section{Figure 3.72. Radiological Distribution for Paducah Gaseous Diffustion Plant Derived for the ITTS Study}

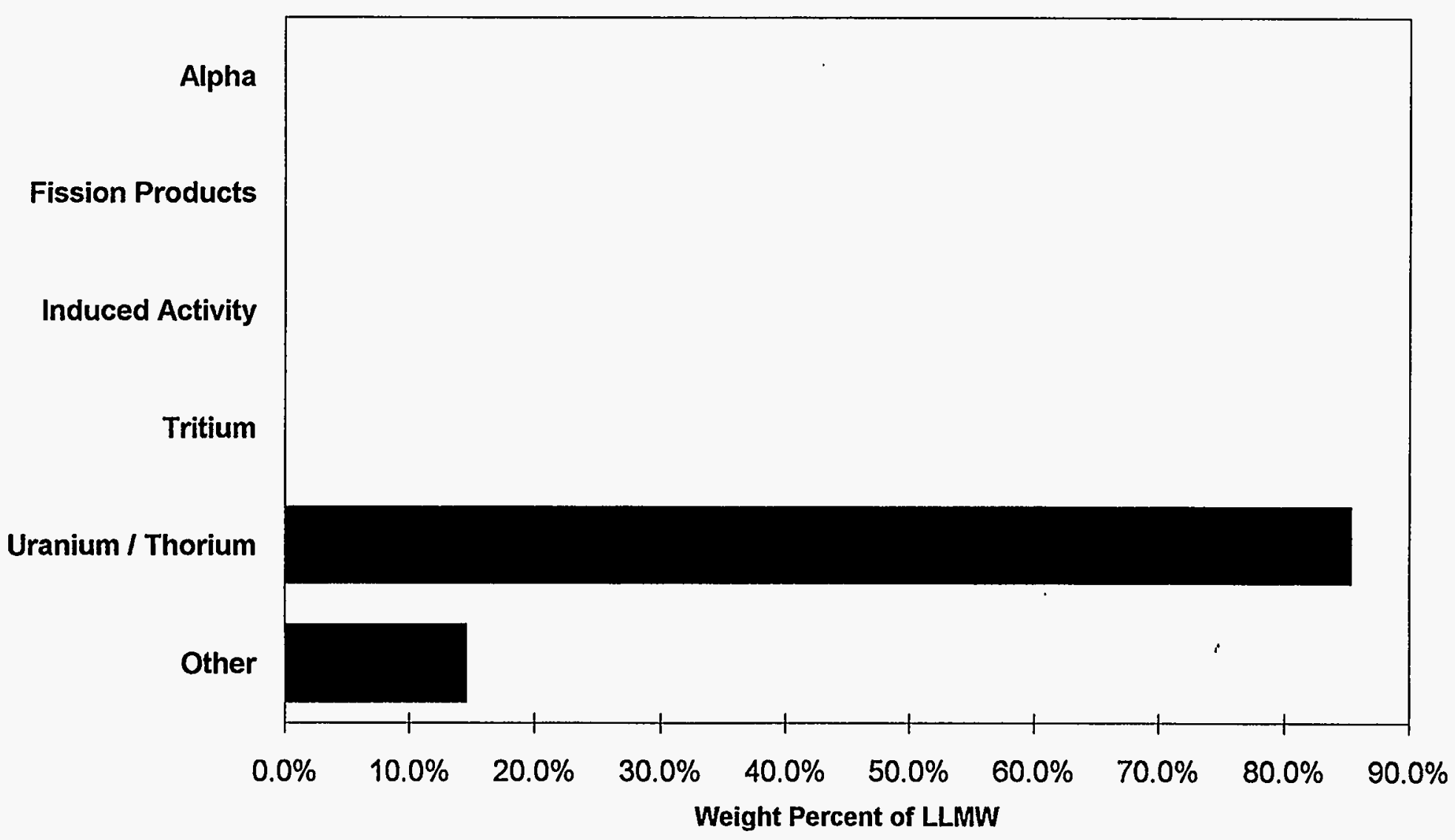

Information obtained from the DOE/RW-0006-Rev.8, October 1992 and EPA 520/1-91-010-2, May 1991. 


\section{Figure 3.73. Physical Matrix Distribution for Pantex Plant Derived for the ITTS Study*}

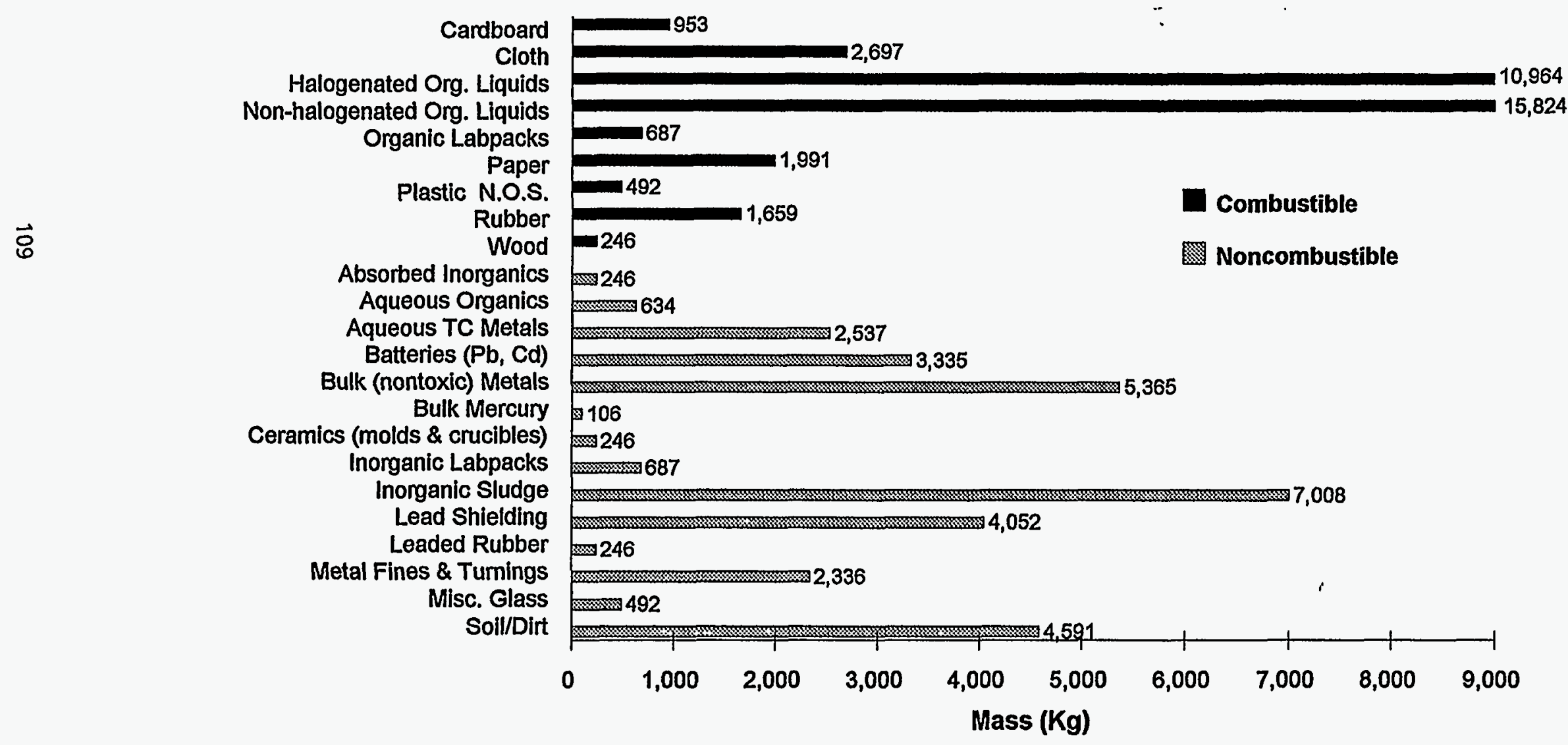

* Does not include mass due to containers.

Information obtained from the DOE/NBM-1100 (MWIR Report), April 1993. 


\section{Figure 3.74. Combustible vs Noncombustible for Pantex Plant Derived for the ITTS Study (TOTAL=67,393 Kg)*}

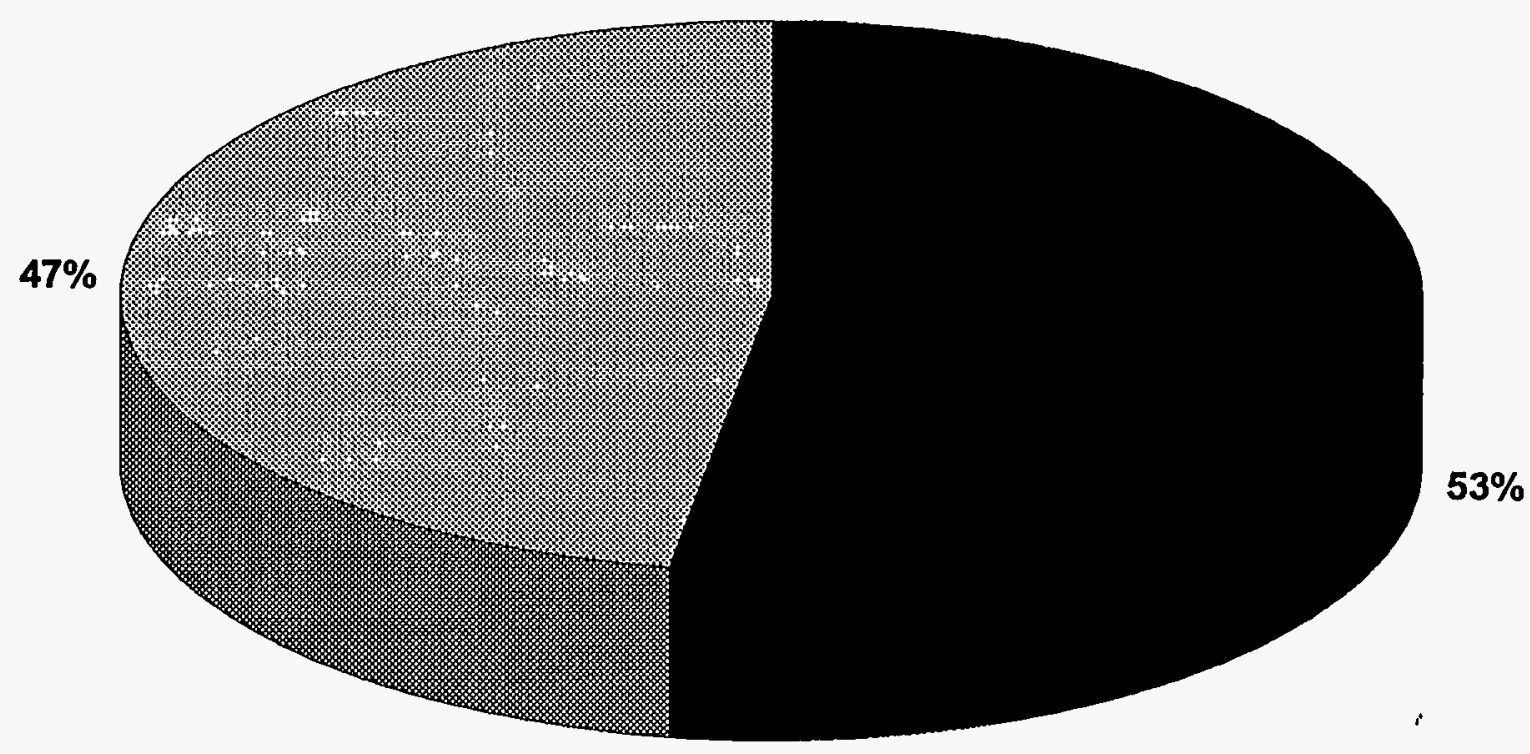

Combustible Noncombustible 


\section{Figure 3.75. Combustible Physical Matrix Distribution for Pantex Plant Derived for the ITTS Study (Combustibles=35,513 Kg)*}

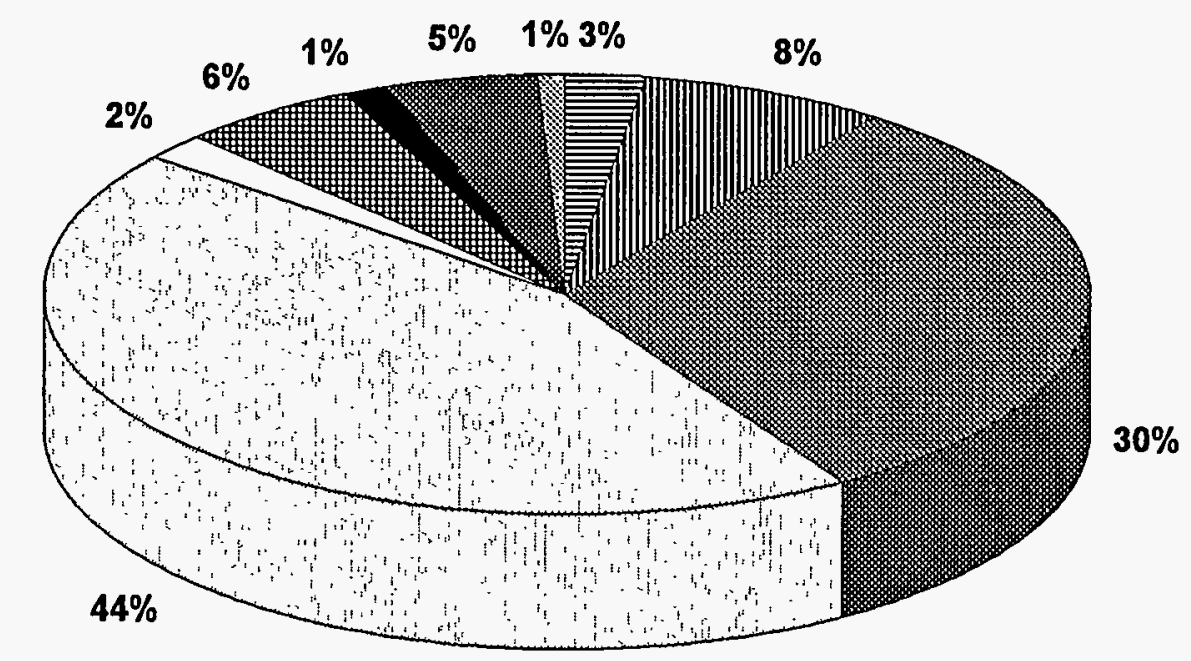

\begin{tabular}{|c|c|c|c|c|}
\hline 冒 Cardboard & 䤉 Cloth & $\begin{array}{l}\text { Halogenated Org. } \\
\text { Liquids }\end{array}$ & $\begin{array}{l}\text { Non-halogenated } \\
\text { Org. Liquids }\end{array}$ & $\square$ Organic Labpacks \\
\hline 唺 Paper & Plastic N.O.s. & Rubber & Wood & \\
\hline
\end{tabular}




\section{Figure 3.76. Noncombustible Physical Matrix Distribution for Pantex Plant Derived for the ITTS Study (Noncombustibles $=31,880 \mathrm{Kg}$ )}

\begin{tabular}{|c|c|c|c|}
\hline Aqueous Organics & Alill Aqueous TC Metals & Batteries $(P b, C d)$ & $\begin{array}{l}\text { Bulk (nontoxic) } \\
\text { Metals }\end{array}$ \\
\hline$\square$ Inorganic Labpacks & Inorganic Sludge & 2 Lead Shielding & $\begin{array}{l}\text { Metal Fines \& } \\
\text { Turnings }\end{array}$ \\
\hline Misc. Glass & Other & 亘 Soil/Dirt & \\
\hline
\end{tabular}

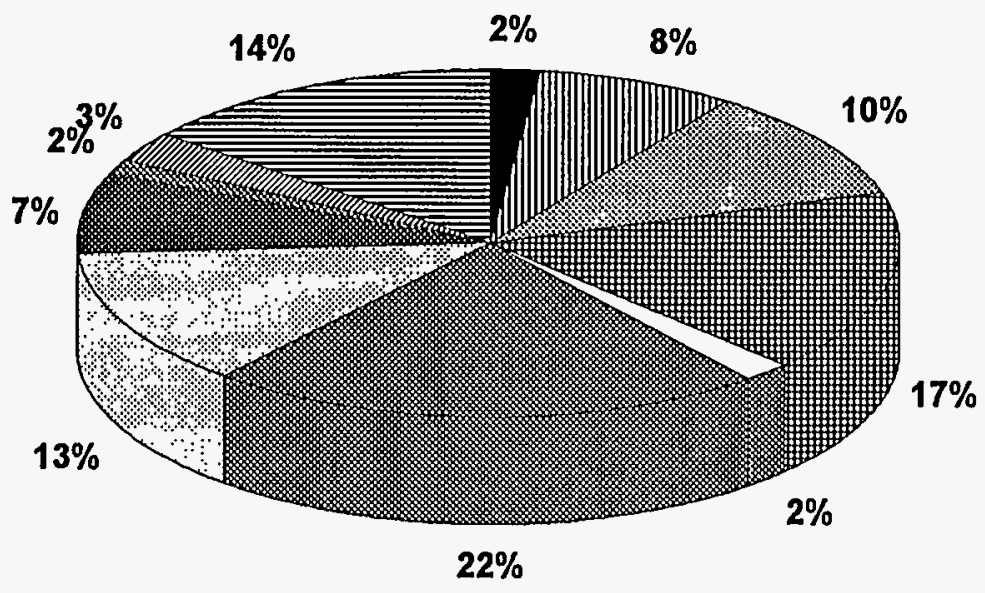

* Does not include mass due to containers.

"Other" Catagory consists of Leaded Rubber, Absorbed Inorganics, Bulk Mercury, and Ceramics.

Information obtained from the DOE/NBM-1100 (MWIR Report), April 1993. 


\section{Figure 3.77. Radiological Distribution for Pantex Plant Derived for the ITTS Study}

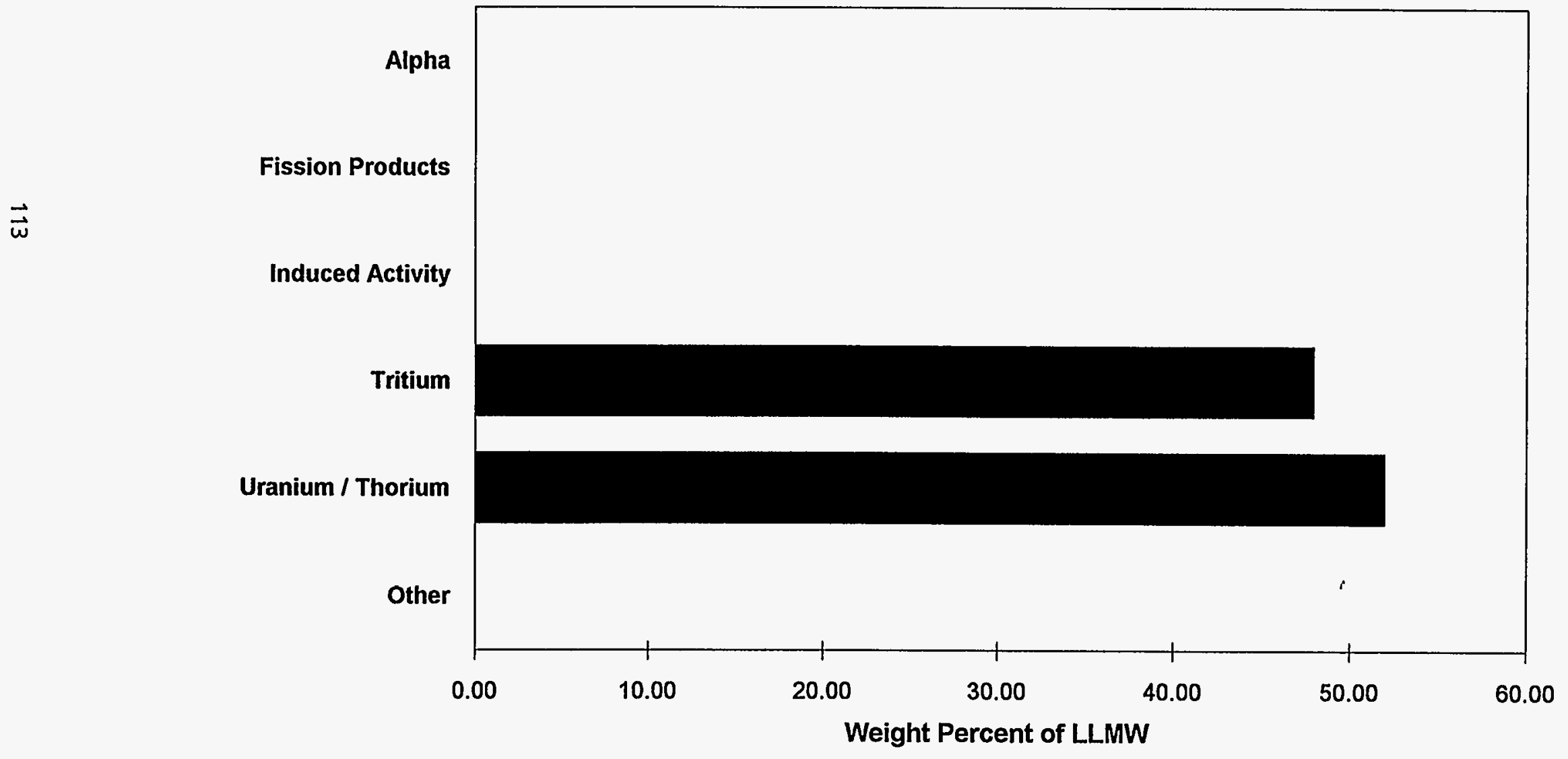




\section{Figure 3.78. Physical Matrix Distribution for Portsmouth Gaseous Diffusion Plant Derived for the ITTS Study}

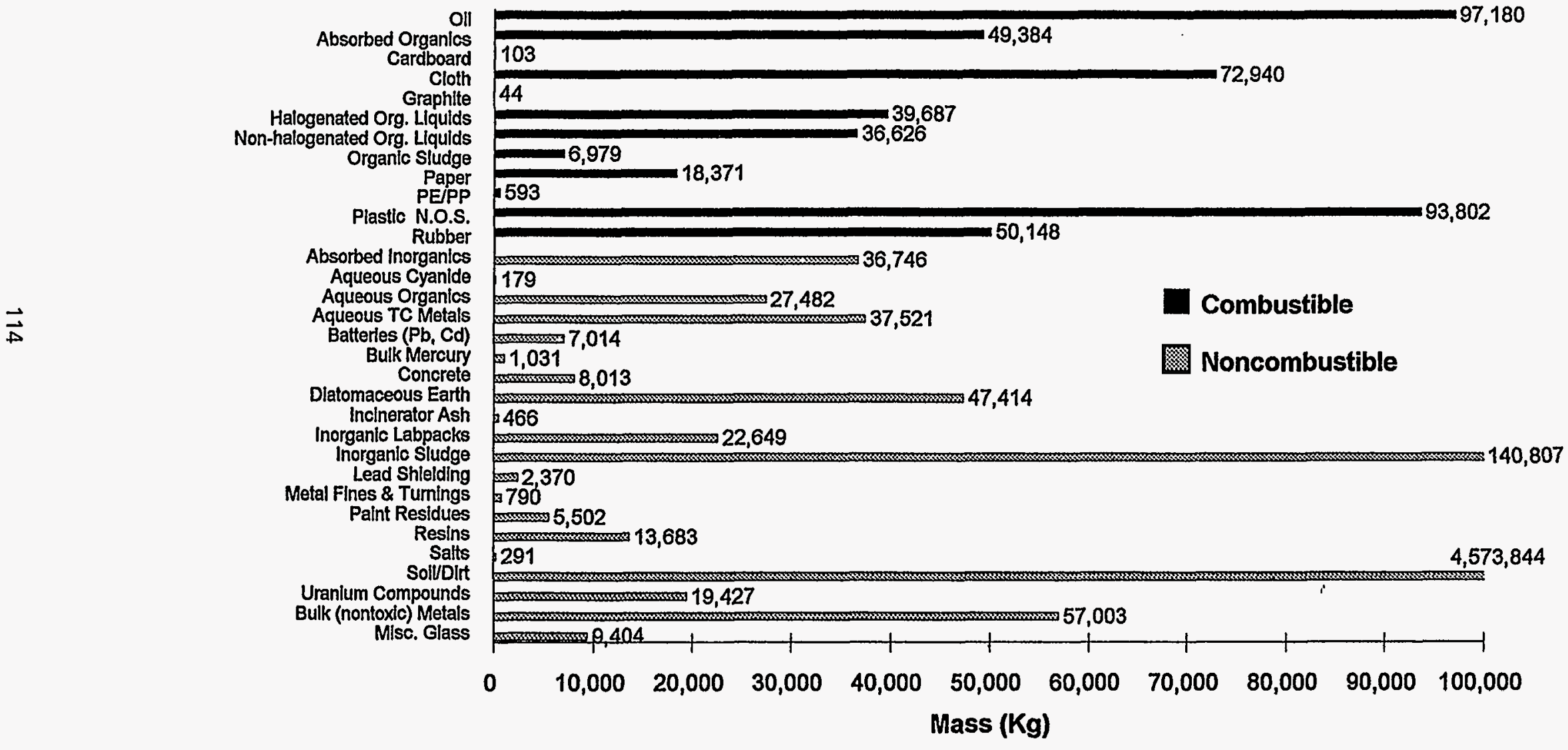

* Does not include mass due to containers.

Information obtained from the DOE/NBM-1100 (MWIR Report), April 1993. 


\section{Figure 3.79. Combustible vs Noncombustible for Portsmouth Gaseous Diffusion Plant Derived for the ITTS Study (TOTAL $=5,477,490 \mathrm{Kg})^{*}$}

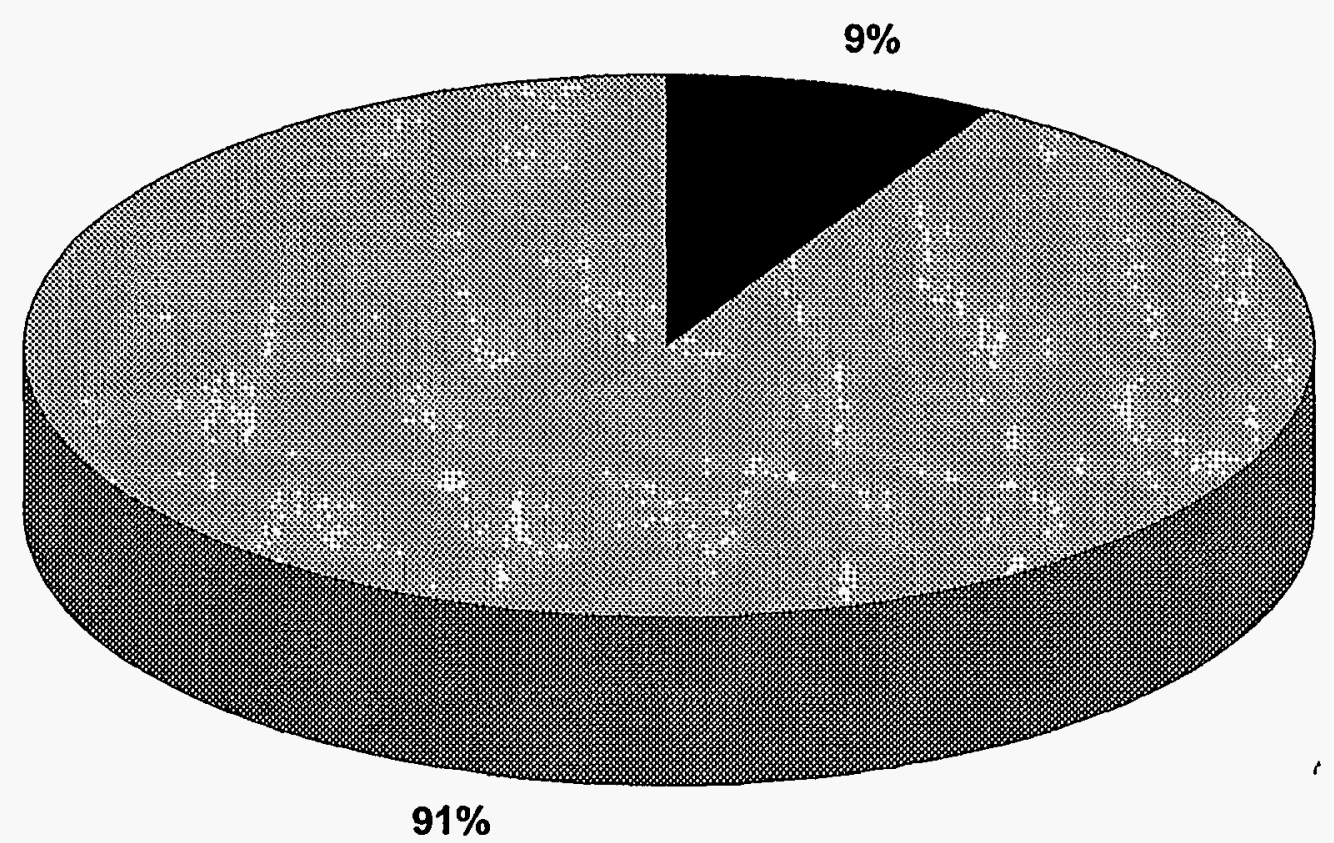

Combustible Noncombustible 


\section{Figure 3.80. Combustible Physical Matrix Distribution for Portsmouth Gaseous Diffusion Plant Derived for the ITTS Study (Combustibles $=465,855 \mathrm{Kg}$ )}

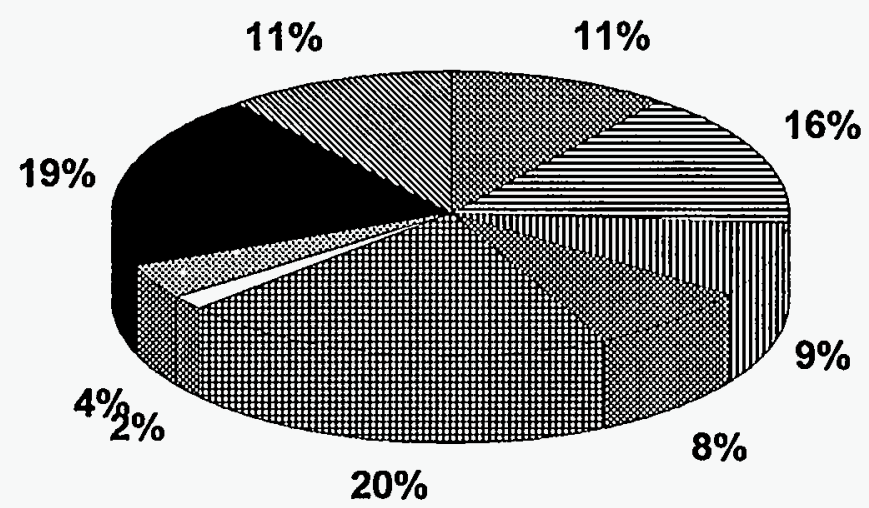

\begin{tabular}{lll}
$\begin{array}{ll}\text { Absorbed Organics } \\
\text { 目 Cloth }\end{array}$ & $\begin{array}{c}\text { Nill Halogenated Org. } \\
\text { Liquids } \\
\text { Org. Liquids }\end{array}$ \\
$\begin{array}{lll}\text { Paper } & \text { Oil } & \\
\text { Other }\end{array}$ \\
\hline Plastic N.O.S. & $\mathbb{N}$ Rubber
\end{tabular}

* Does not include mass due to containers.

"Other" consists of Cardboard, Graphite, Organic Sludge, and PE/PP.

Information obtained from the DOE/NBM-1100 (MWIR Report), April 1993. 


\section{Figure 3.81. Noncombustible Physical Matrix Distribution for Portsmouth Gaseous Diffusion Plant Derived for the ITTS Study (Noncombustibles $=5,011,635 \mathrm{Kg}$ )}

Bulk (nontoxic) Metals Inorganic Sludge $\quad \square$ Other

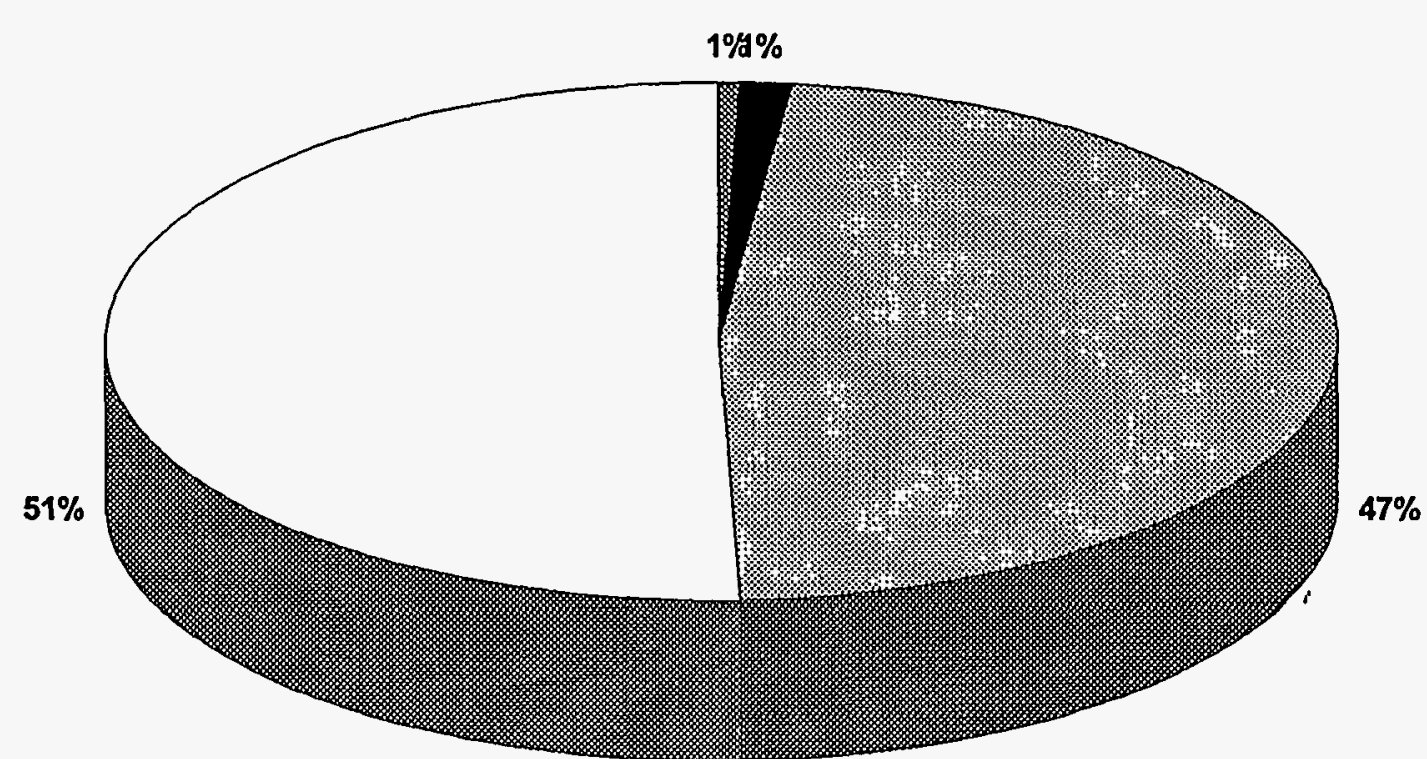

"Other" consists of Glass,

Uranium Compounds, Salts, Resins, Paint Residues, Meta

Fines \& Turnings, Lead

Shielding, Inorg Sludge, Inorg Labpacks, Incinerator Ash,

Diatomaceous Earth,

Concrete, Bulk Mercury,

Batteries, Aqueous TC Metal

Aqueous Org., Aqueous

Cyanide, Absorbed Inorg. 


\section{Figure 3.82. Radiological Distribution for Portsmouth Gaseous Diffusion Plant Derived for the ITTS Study}

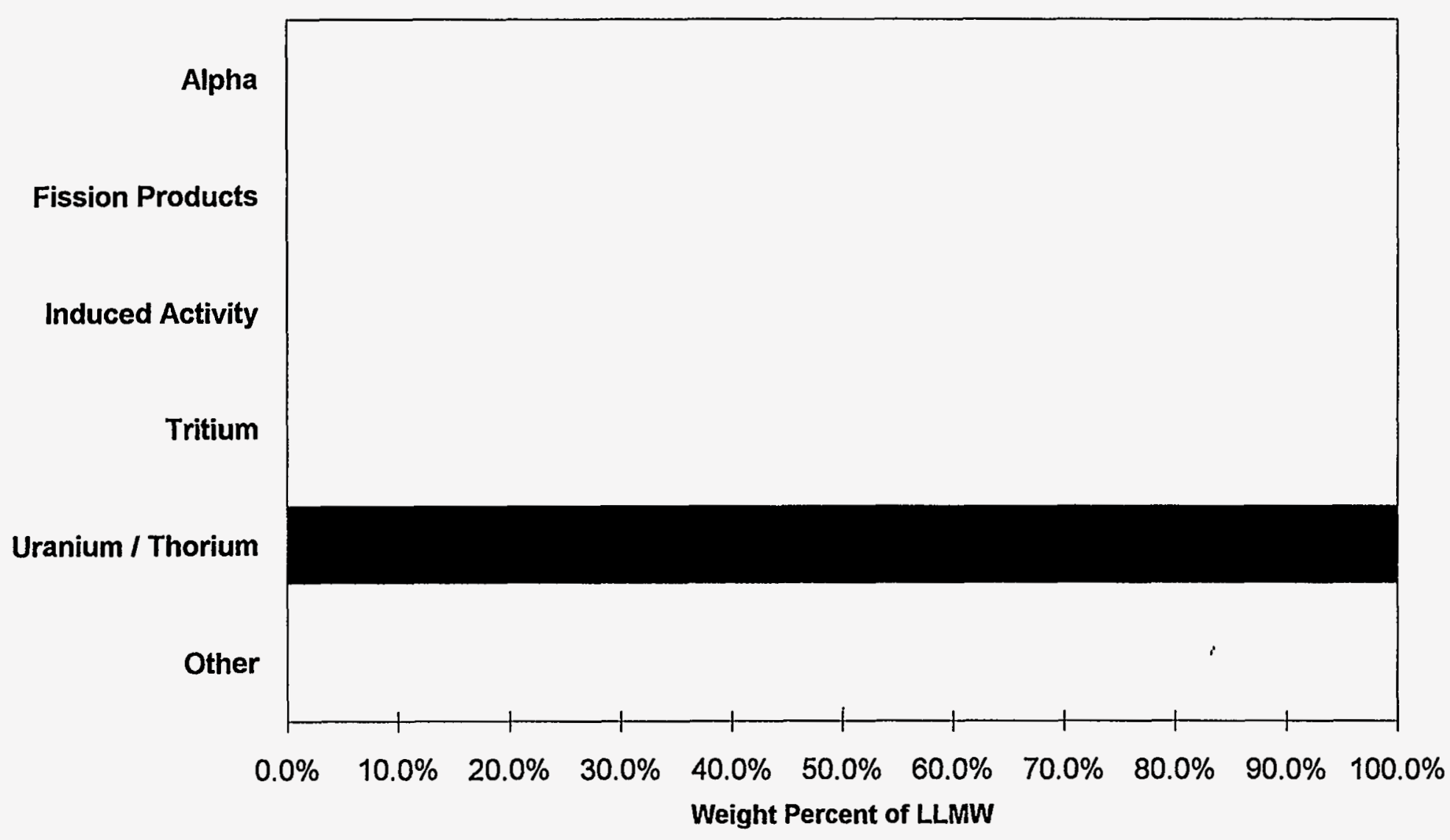

Information obtained from the DOE/RW-006-Rev.8, October 1992 and EPA 520/1-91-010-2, May 1991. 


\section{Figure 3.83. Physical Distribution Matrix for Puget Sound Naval Shipyard Derived for the ITTS Study*}

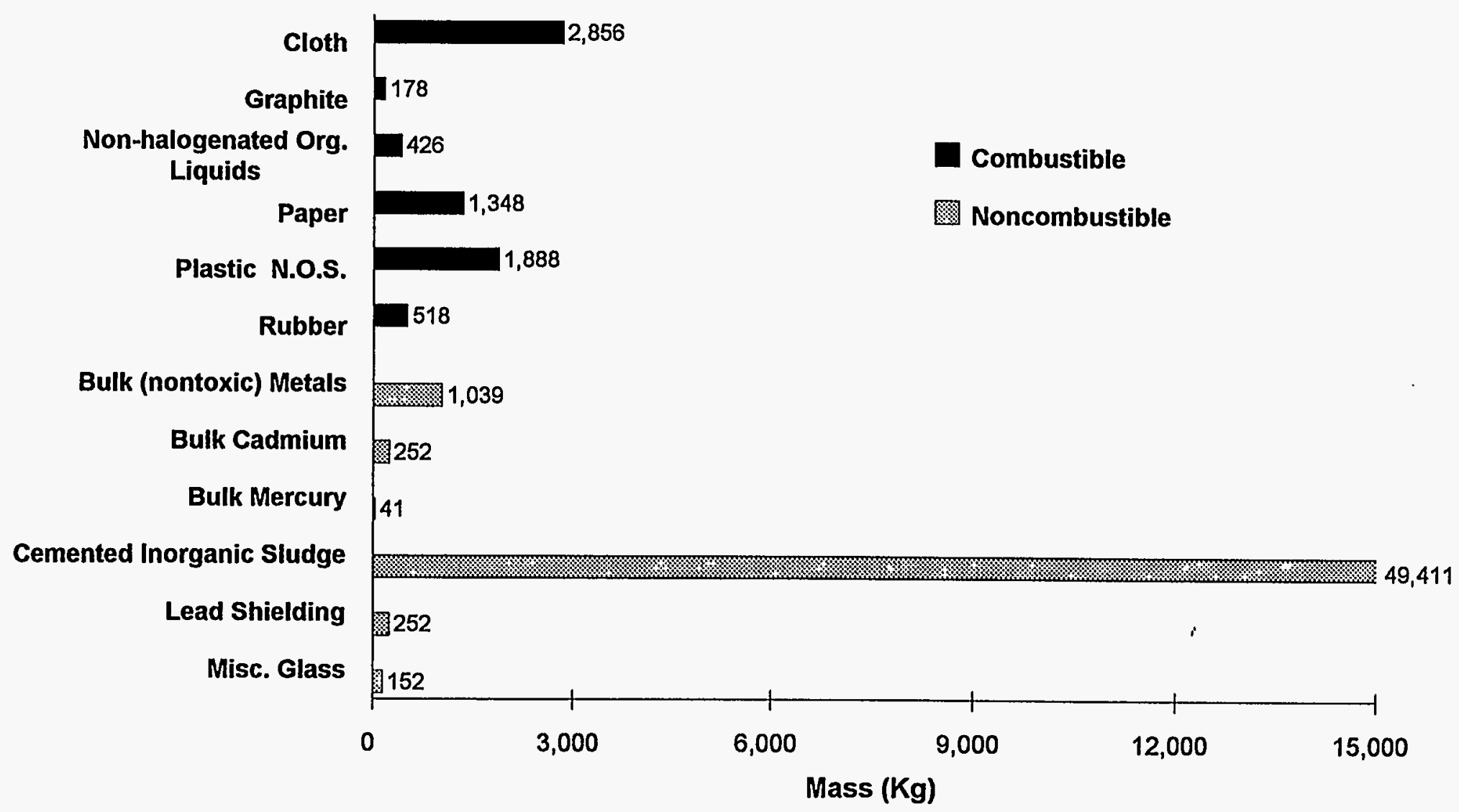




\section{Figure 3.84. Combustible vs Noncombustible for Puget Sound Naval Shipyard Derived for the ITTS Study (TOTAL $=58,360 \mathrm{Kg}$ )}

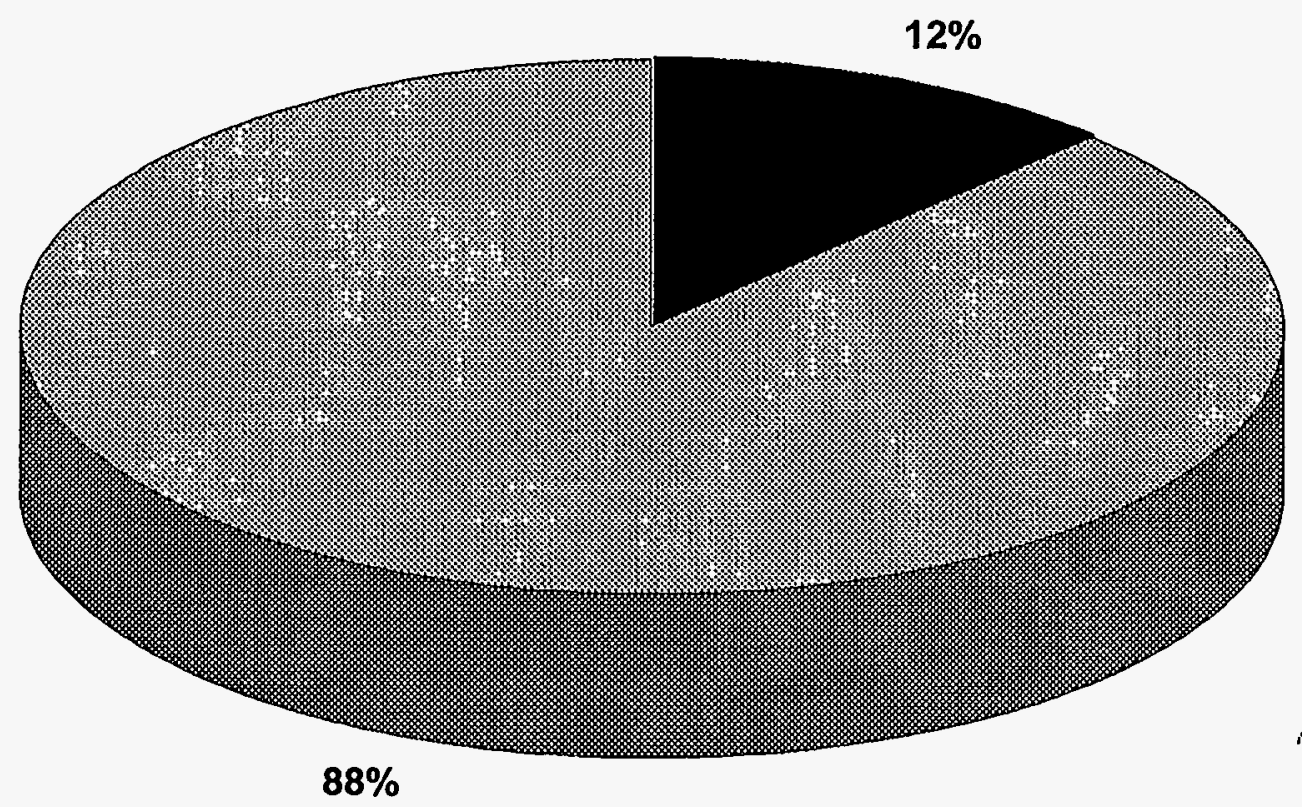

Combustible Noncombustible 


\section{Figure 3.85. Combustible Physical Matrix Distribution for Puget Sound Naval Shipyard Derived for the ITTS Study (Combustibles=7,213 Kg)*}

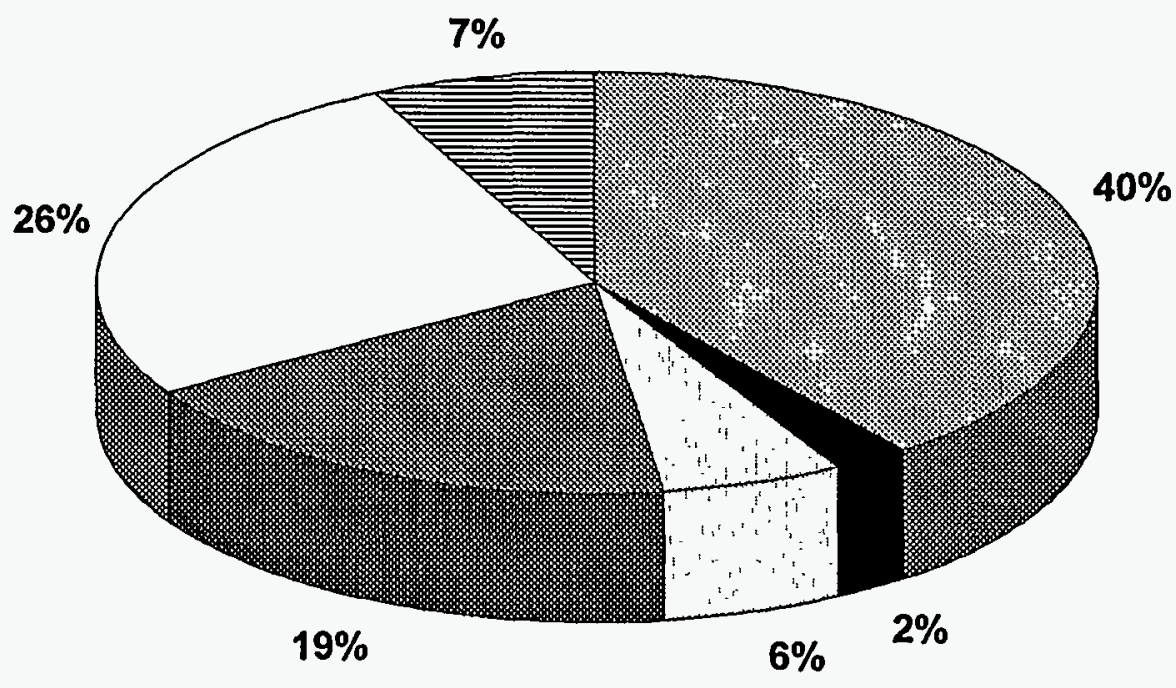

Cloth Graphite $\square$ Non-halogenated

Plastic N.O.S. 冒 Rubber 


\section{Figure 3.86. Noncombustible Physical Matrix Distribution for Puget Sound Naval Shipyard Derived for the ITTS Study (Noncombustibles=51,146 Kg)*}

Bulk (nontoxic) Metals Cemented Inorganic Sludge $\square$ other

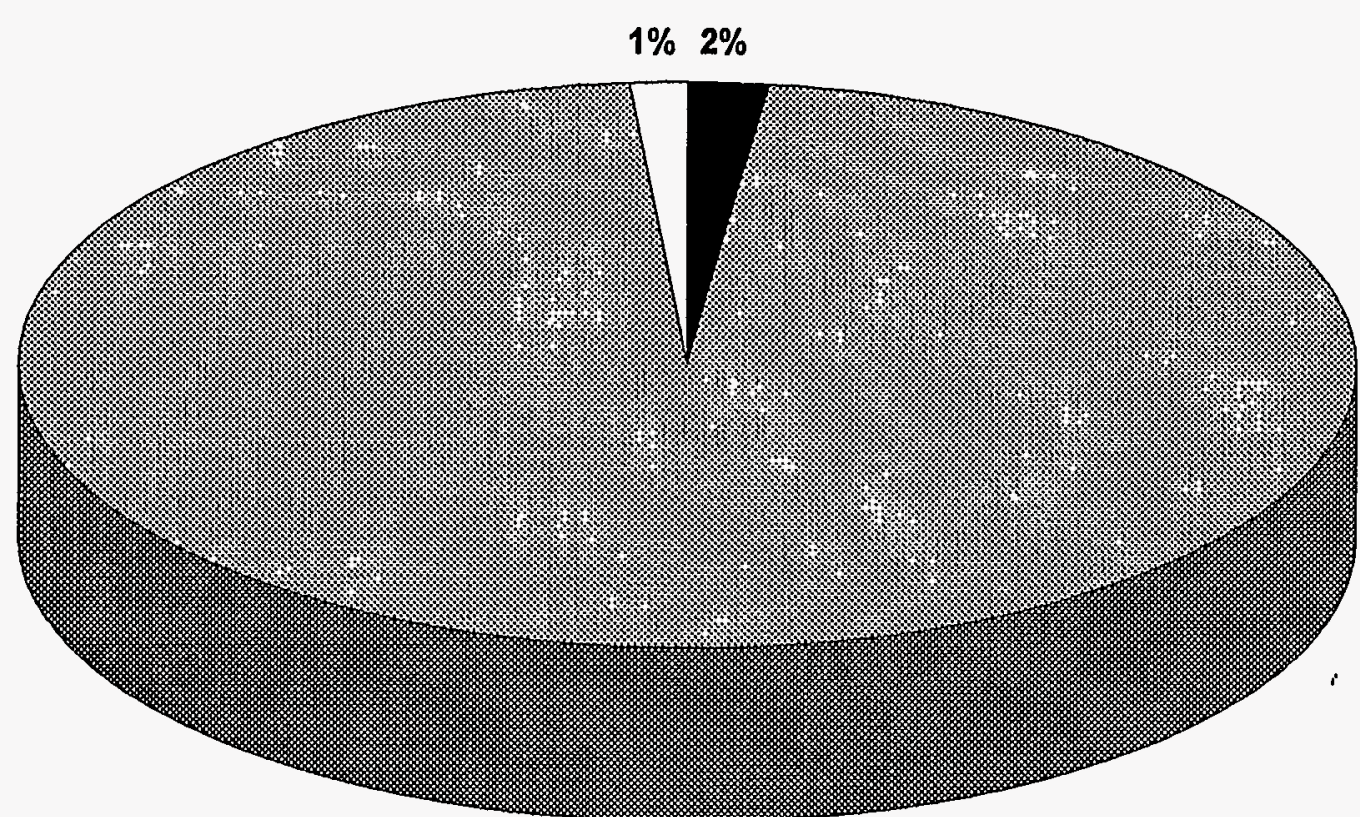

$97 \%$

${ }^{\star}$ Does not include mass due to containers.

"Other" Catagory consists of Bulk Cadmium, Bulk Mercury, Miscellaneous Glass, and Lead Shielding.

Information obtained from the DOE/NBM-1100 (MWIR Report), April 1993. 


\section{Figure 3.87. Radiological Distribution for Puget Sound Naval Shipyard Derived for the ITTS Study}

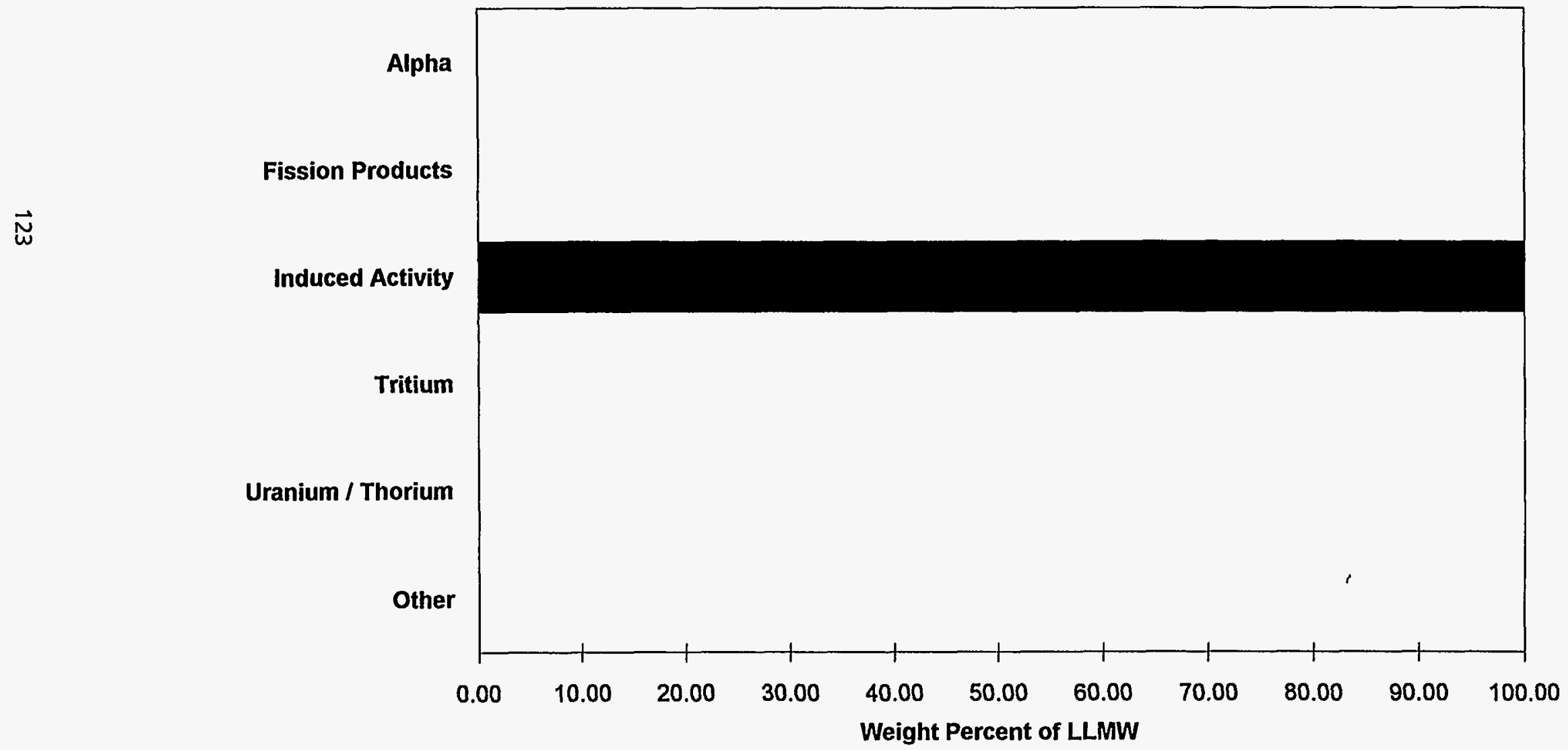




\section{Figure 3.88. Physical Matrix Distribution for Rocky Flats Plant Derived for the ITTS Study*}

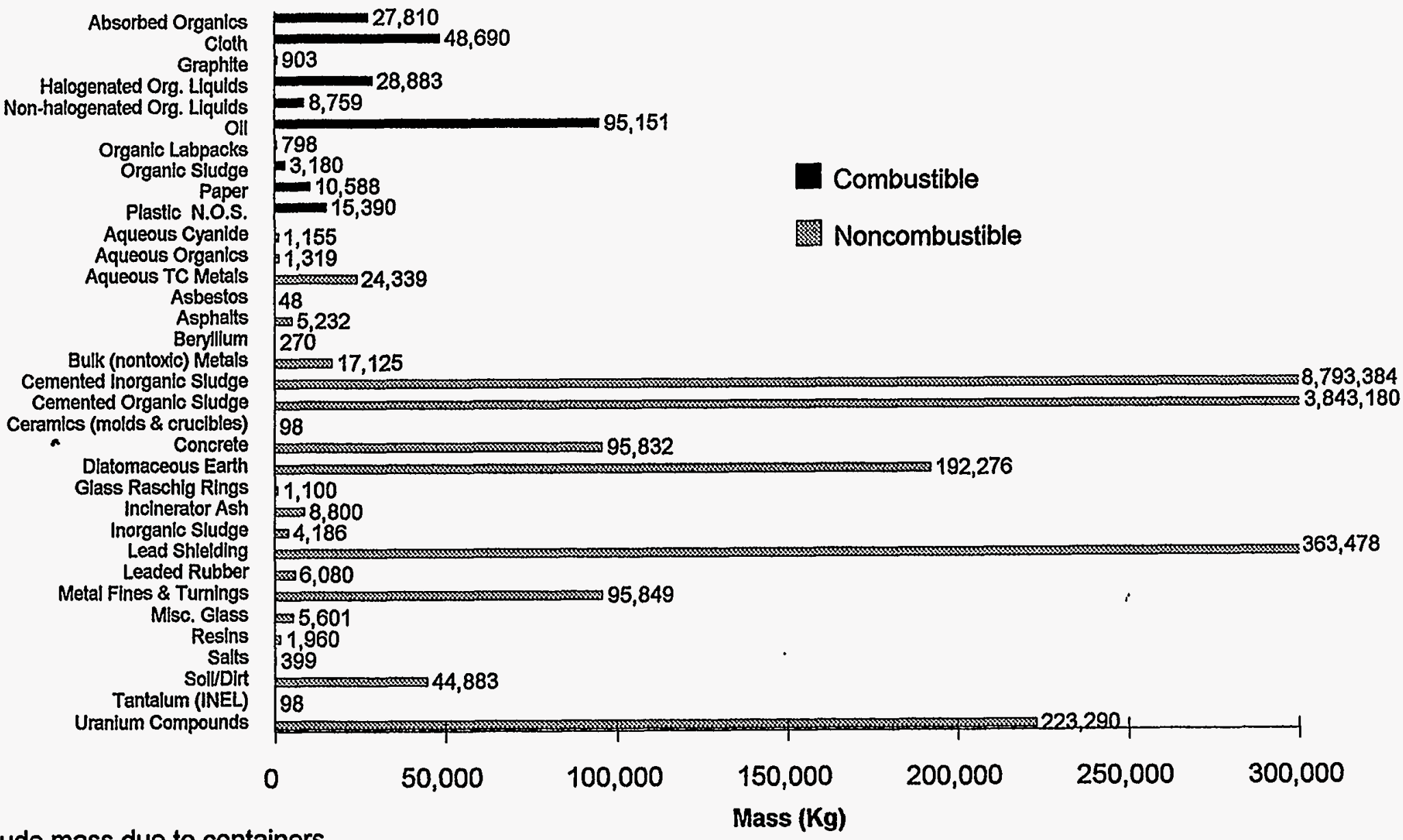

* Does not include mass due to containers.

Information obtained from the DOE/NBM-1100 (MWIR Report), April 1993. 


\section{Figure 3.89. Combustible vs Noncombustible for Rocky Flats Plant Derived for the ITTS Study (TOTAL=13,970,130 Kg)*}

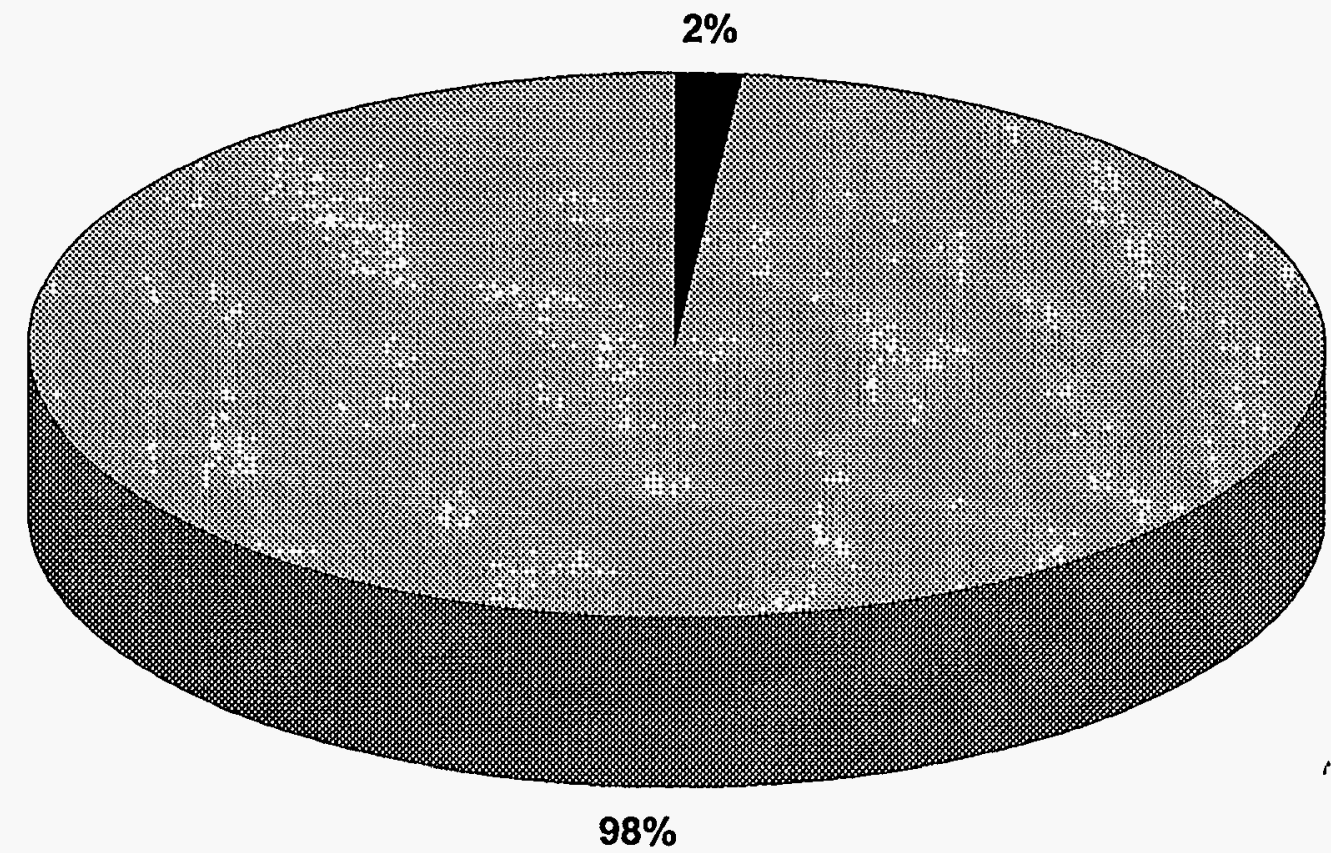

Combustible Noncombustible

* Does not include mass due to containers.

Information obtained from the DOE/NBM-1100 (MWIR Report), April 1993. 


\section{Figure 3.90. Combustible Physical Matrix Distribution for Rocky Flats Plant Derived for the ITTS Study (Combustibles $=240,151 \mathrm{Kg})^{*}$}

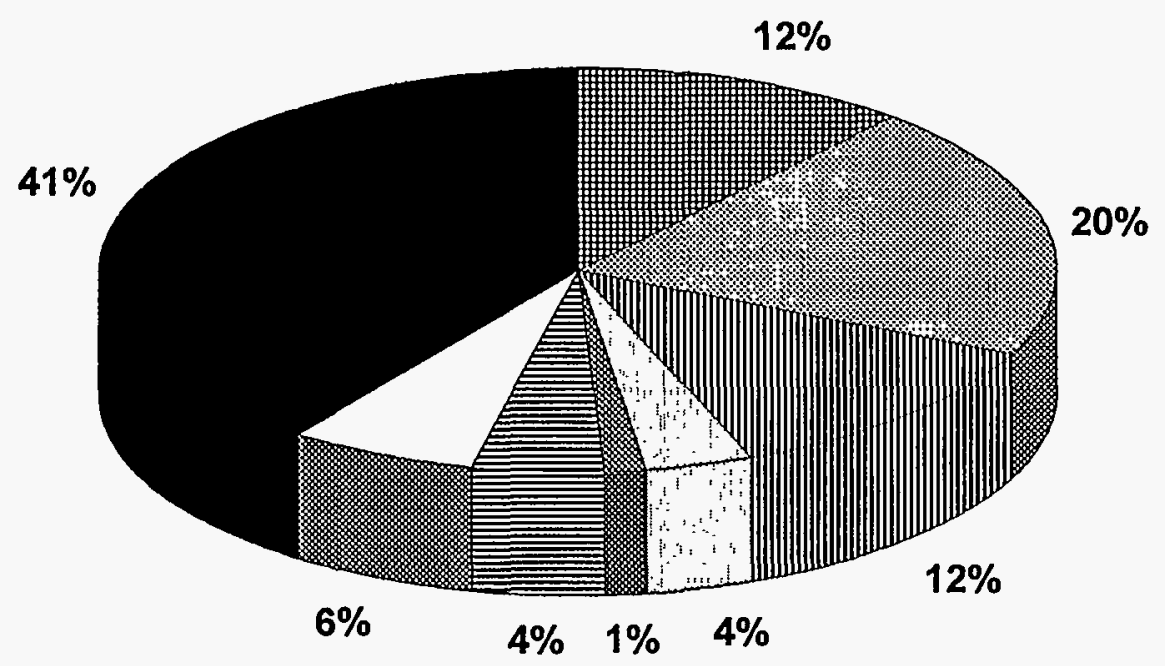
傮㻃 Absorbed Cloth
Organics
Organic Sludge Paper
IIll Halogenated Org. $\square$ Non-halógenated Liquids Org. Liquids
$\square$ Plastic N.O.S. $\square$ Oil




\section{Figure 3.91. Noncombustible Physical Matrix Distribution for Rocky Flats Plant Derived for the ITTS Study (Noncombustibles=13,729,979 Kg)*}

$\begin{array}{lll}\begin{array}{ll}\text { Cemented } \\ \text { Inorganic Sludge }\end{array} & \begin{array}{l}\text { Organic Sludge } \\ \text { Oemented }\end{array} & \text { Lead Shielding } \\ \text { 监 Other } & \begin{array}{l}\text { Diatomaceous } \\ \text { Earth }\end{array} & \begin{array}{l}\text { Uranium } \\ \text { Compounds }\end{array}\end{array}$

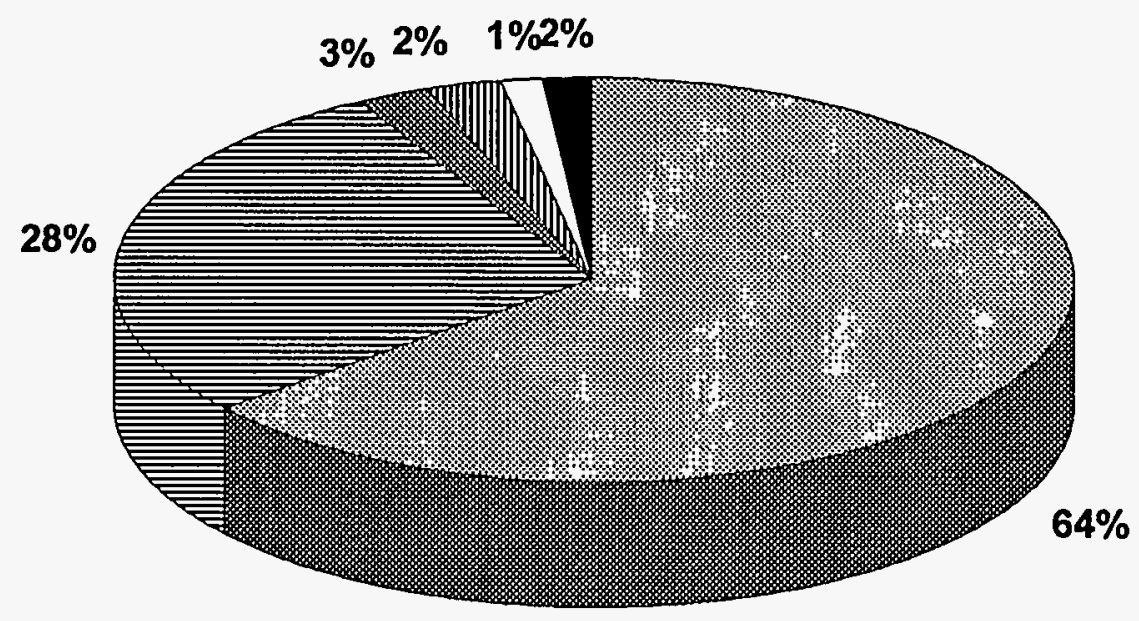




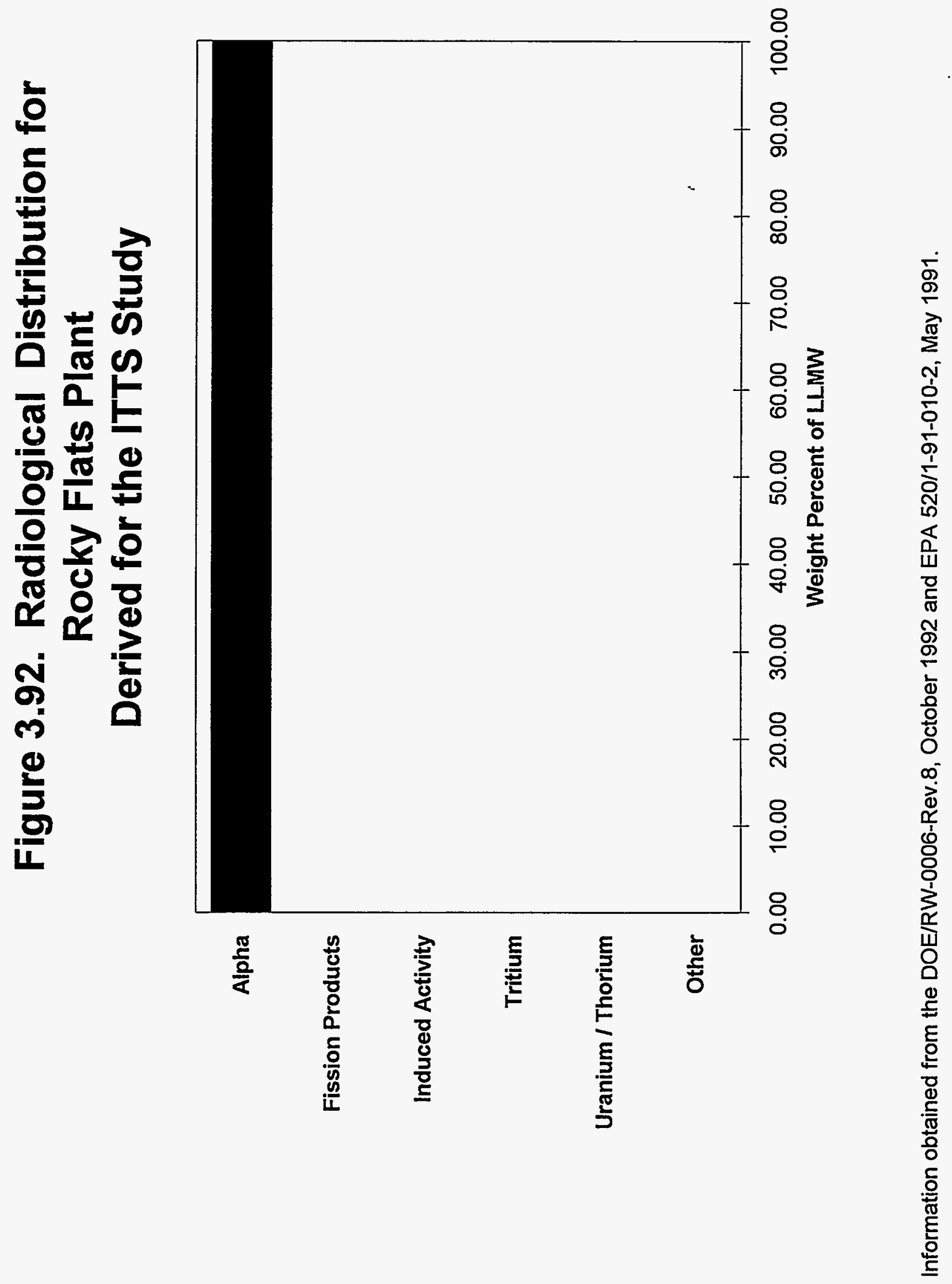




\section{Figure 3.93. Physical Matrix Distribution for Sandia National Laboratory Derived for the ITTS Study*}

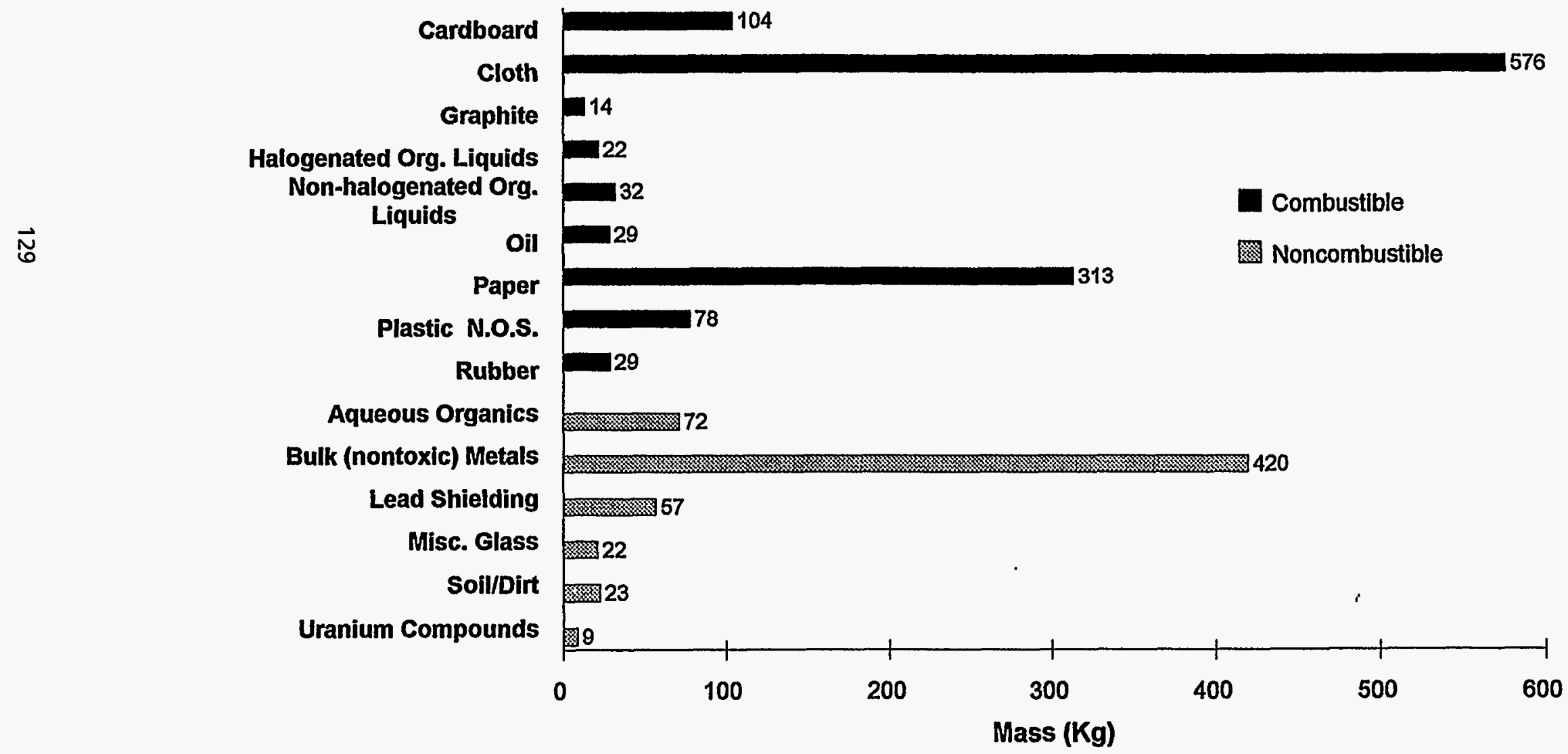

* Does not include mass due to containers.

Information obtained from the DOE/NBM-1100 (MWIR Report), April 1993. 


\section{Figure 3.94. Combustible vs Noncombustible for Sandia National Laboratory Derived for the ITTS Study (TOTAL=1,801)*}

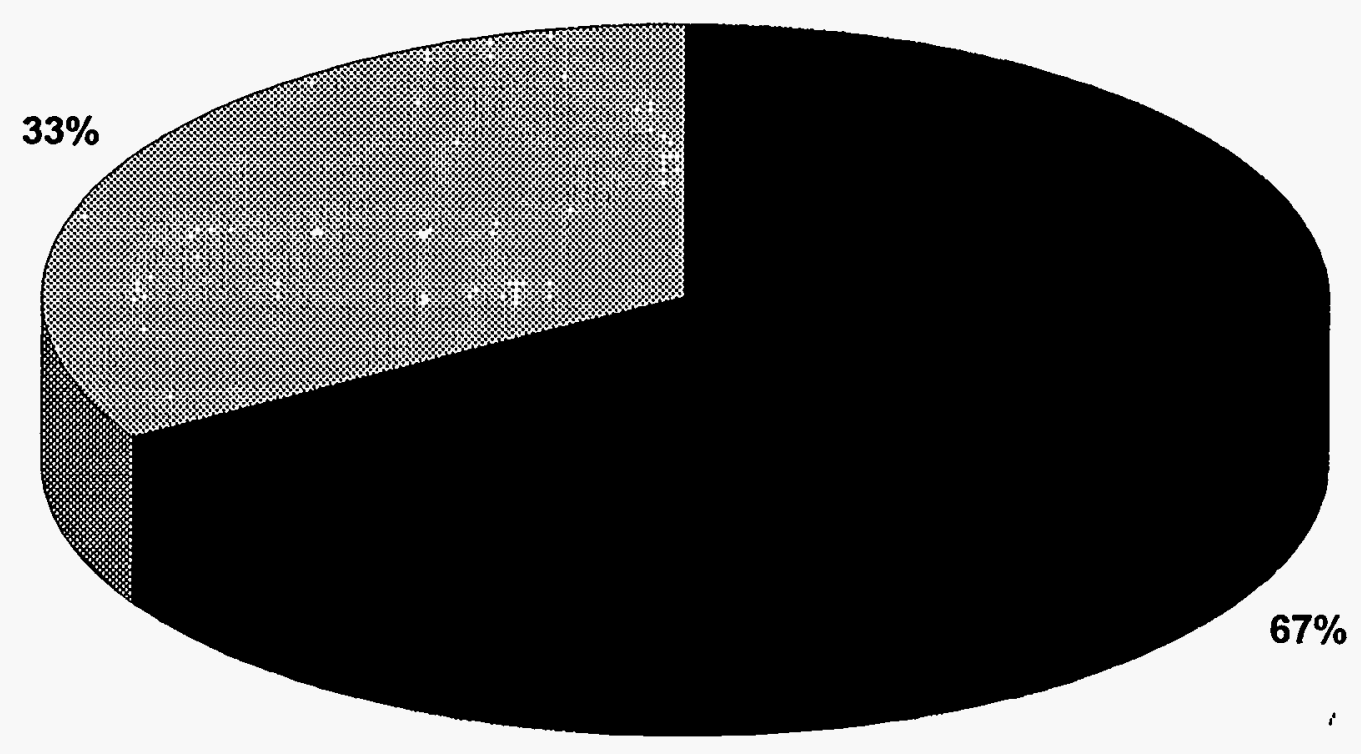

Combustible Noncombustible

* Does not include mass due to containers.

Information obtained from the DOE/NBM-1100 (MWIR Report), April 1993. 


\section{Figure 3.95. Combustible Physical Matrix Distribution for Sandia National Laboratory Derived for the ITTS Study (Combustibles=1,198 Kg)*}

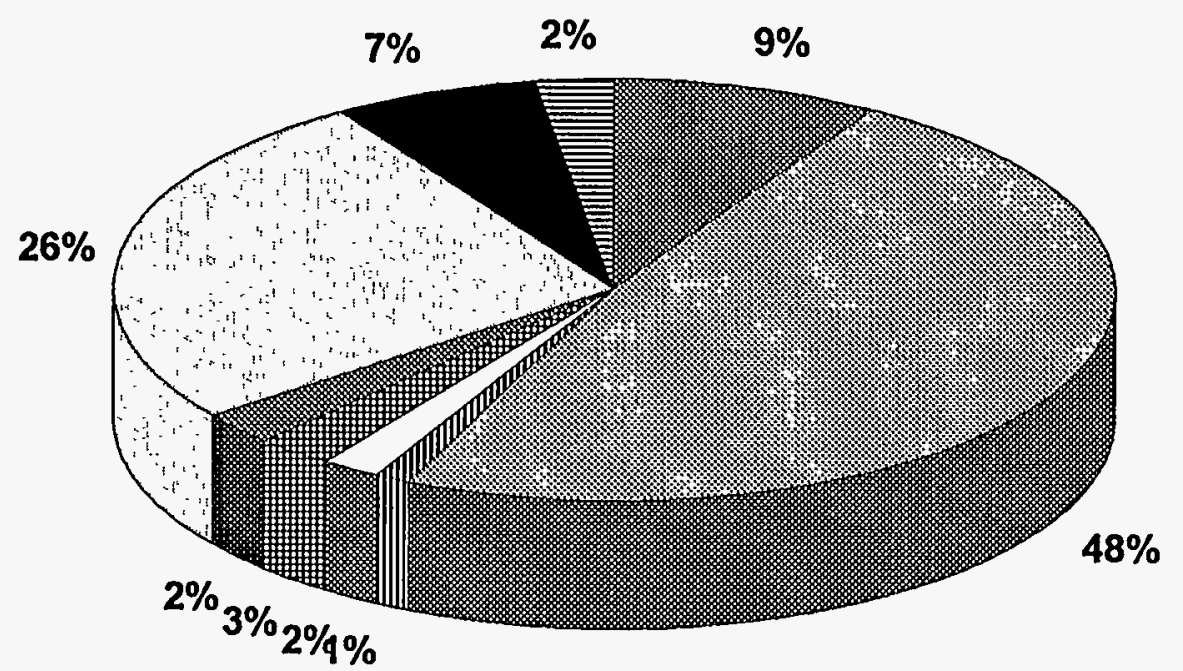

\begin{tabular}{|c|c|c|c|c|}
\hline Cardboard & Cloth & 纤 Graphite & $\begin{array}{l}\square \text { Halogenated Org. } \\
\text { Liquids }\end{array}$ & $\begin{array}{l}\text { 四 Non-halogenated } \\
\text { Org. Liquids }\end{array}$ \\
\hline Oil & $\square$ Paper & Plastic N.O.S. & 圈 Rubber & \\
\hline
\end{tabular}




\section{Figure 3.96. Noncombustible Physical Matrix Distribution for Sandia National Laboratory Derived for the ITTS Study (Noncombustibles $=603 \mathrm{Kg})^{*}$}

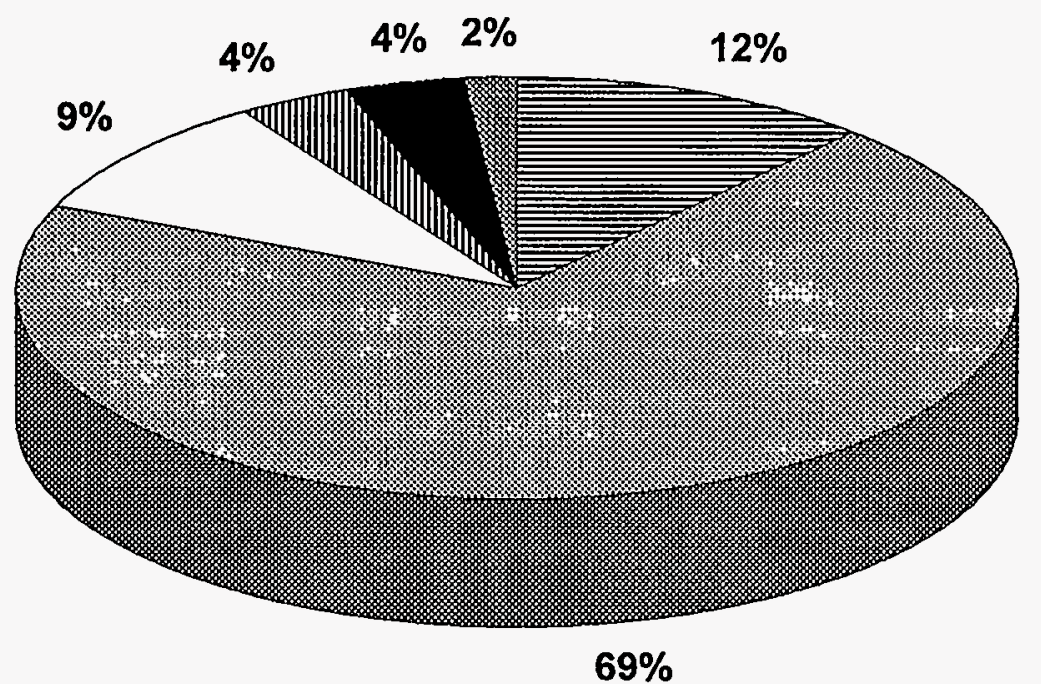

\footnotetext{
䀚 Aqueous Organics Bulk (nontoxic) $\square$ Lead Shielding $\quad$ mill Misc. Glass Metals

Soil/Dirt Uranium

Compounds
} 


\section{Figure 3.97. Radiological Distribution for Sandia National Laboratory Derived for the ITTS Study}

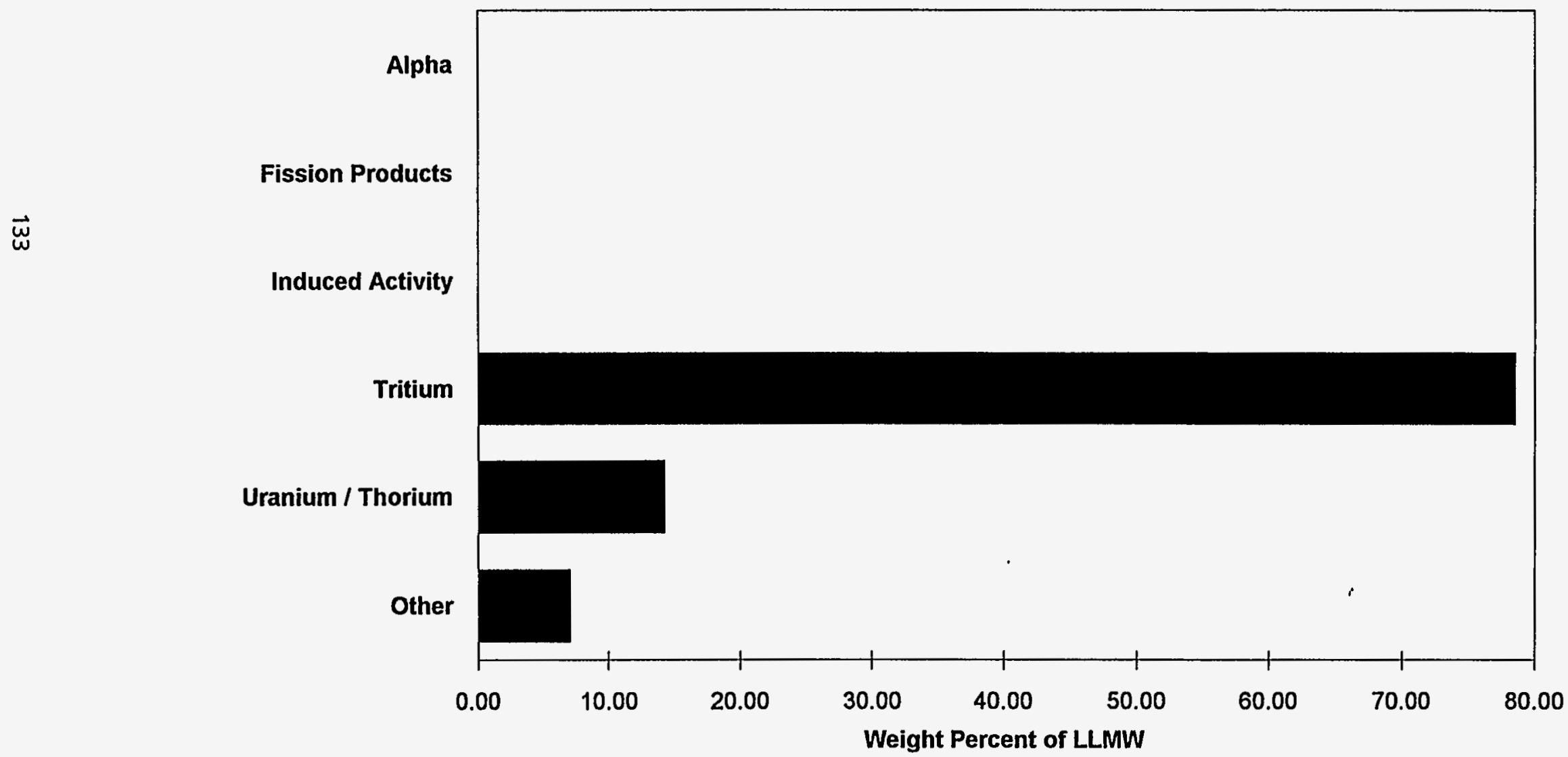




\section{Figure 3.98. Physical Matrix Distribution for Savannah River Site Derived for the ITTS Study*}

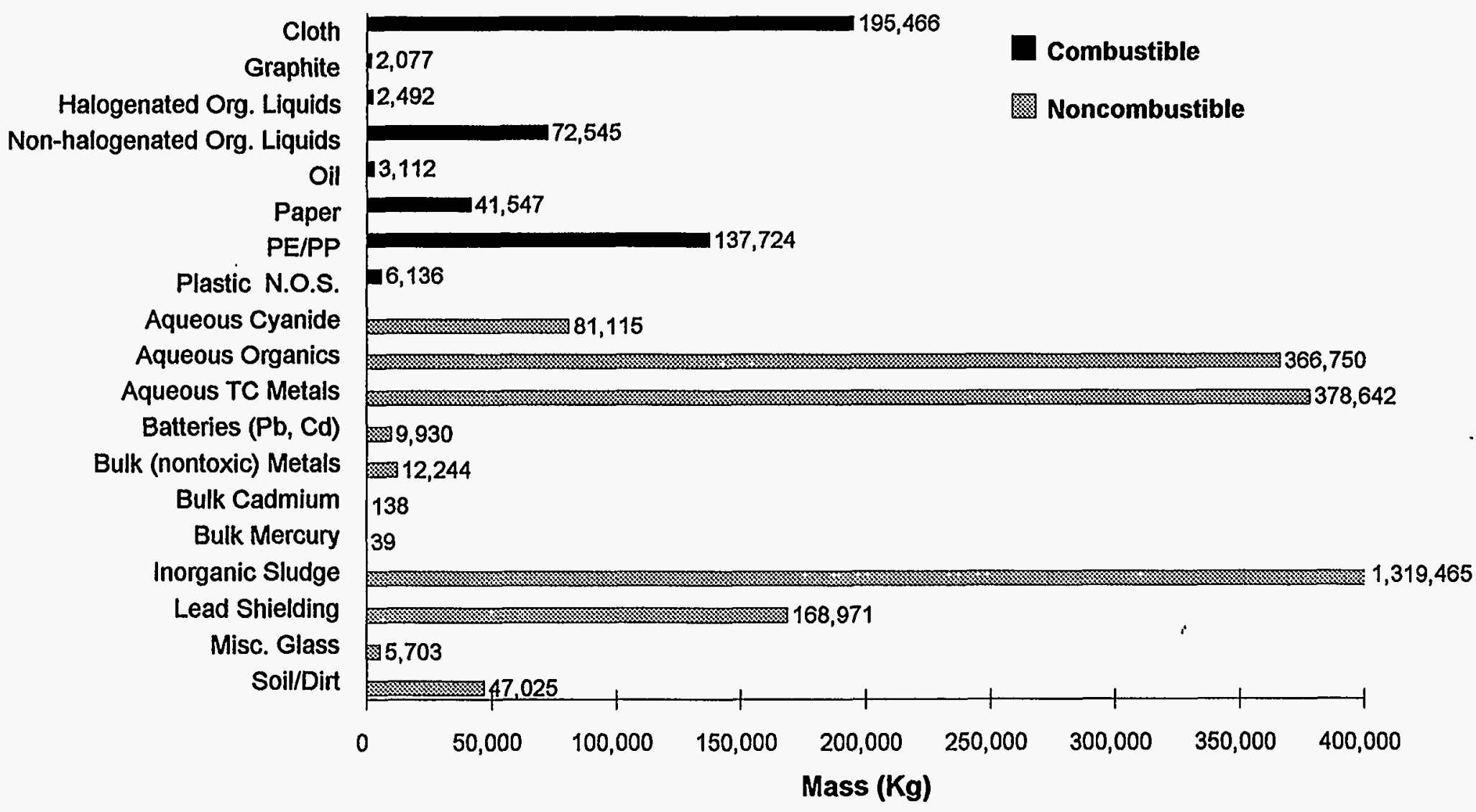




\section{Figure 3.99. Combustible vs Noncombustible for Savannah River Site Derived for the ITTS Study (TOTAL=2,851,122 Kg)*}

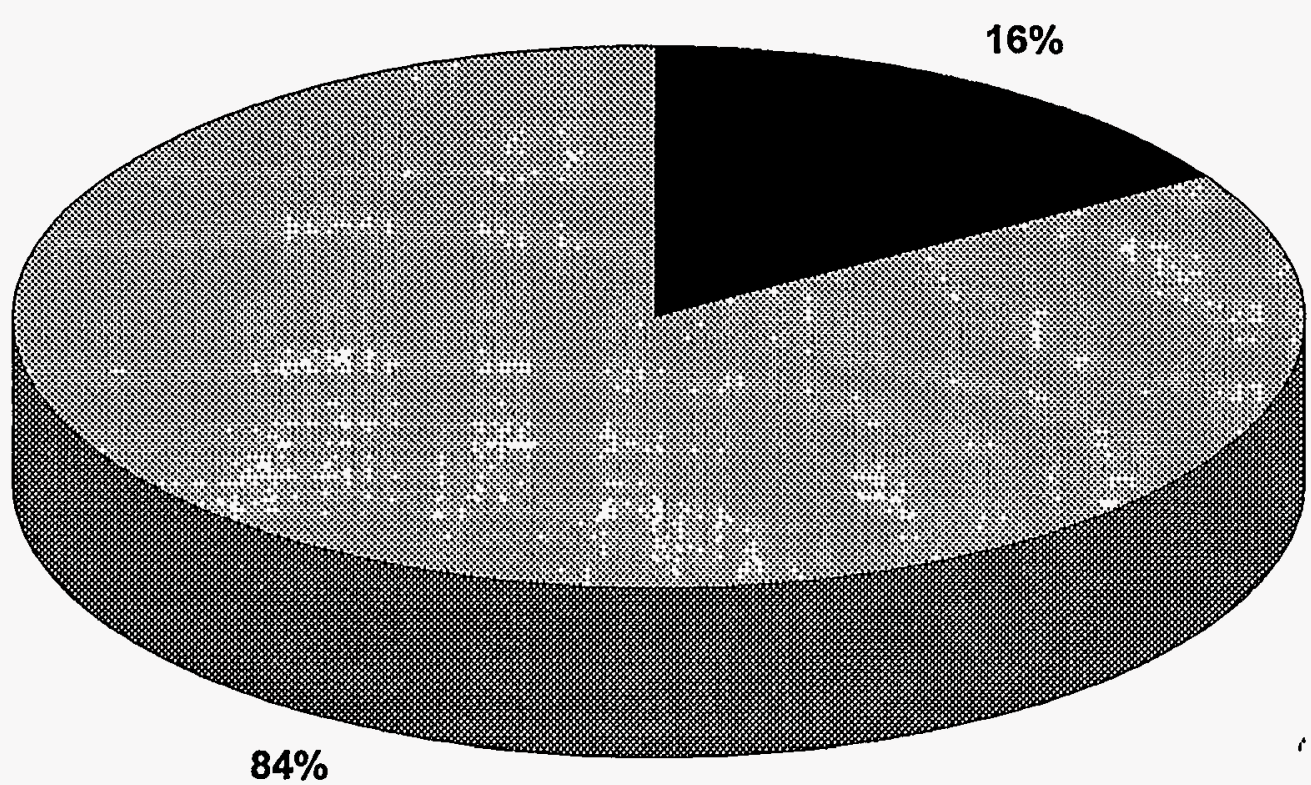

Combustible Noncombustible 


\section{Figure 3.100. Combustible Physical Matrix Distribution for Savannah River Site Derived for the ITTS Study (Combustibles $=461,098 \mathrm{Kg})^{*}$}

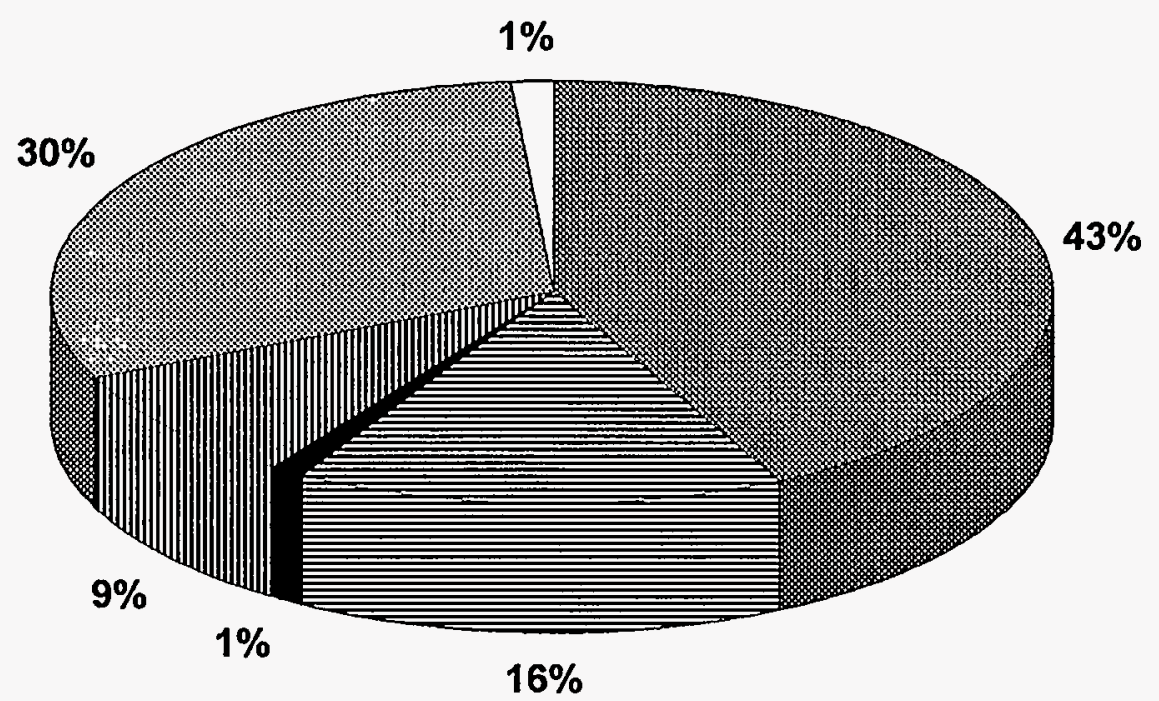

Cloth

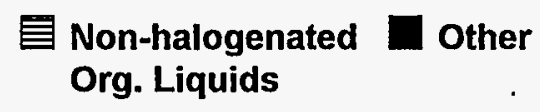

IIll Paper Org. Liquids

W PE/PP $\square$ Plastic N.O.S. 


\section{Figure 3.101. Noncombustible Physical Matrix Distribution for Savannah River Site Derived for the ITTS Study (Noncombustibles $=2,390,024 \mathrm{Kg})^{*}$}

\footnotetext{
Aqueous Cyanide 自 Aqueous Organics 四 Aqueous TC Metals 粗 Inorganic Sludge

Lead Shielding $\square$ Soil/Dirt Other
}

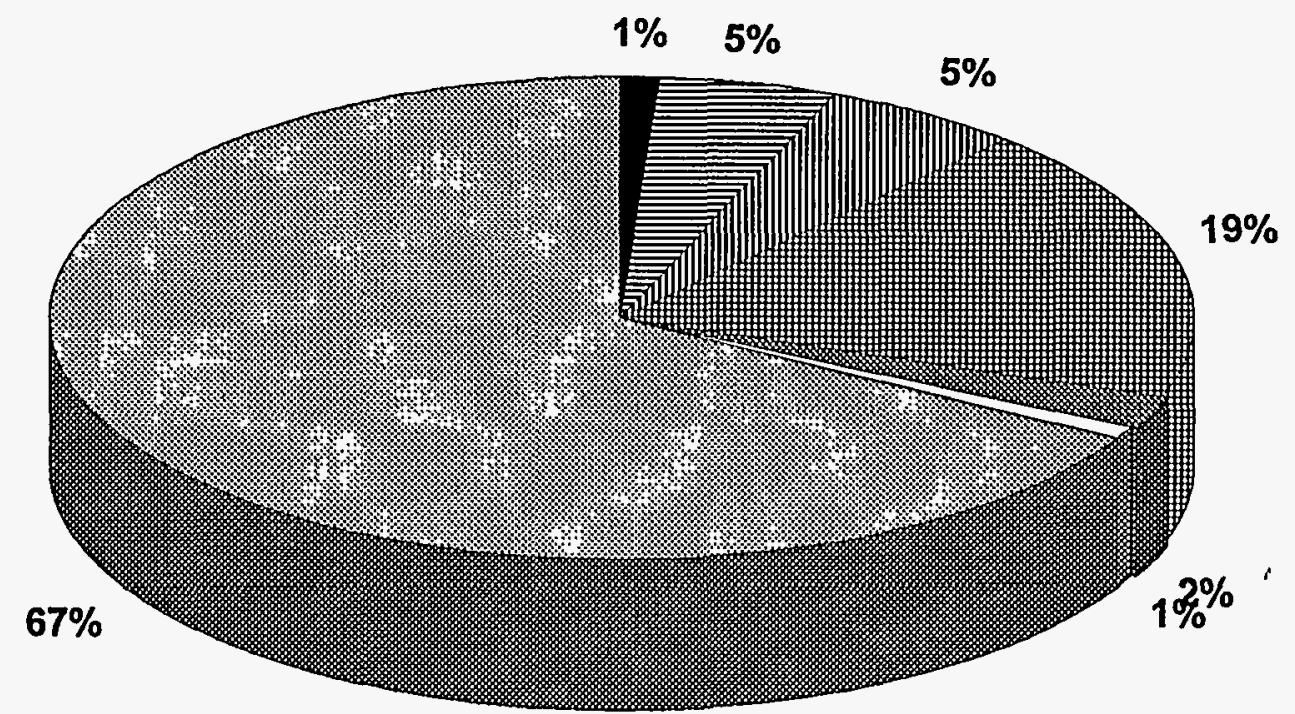




\section{Figure 3.102. Radiological Distribution for Savannah River Site Derived for the ITTS Study}

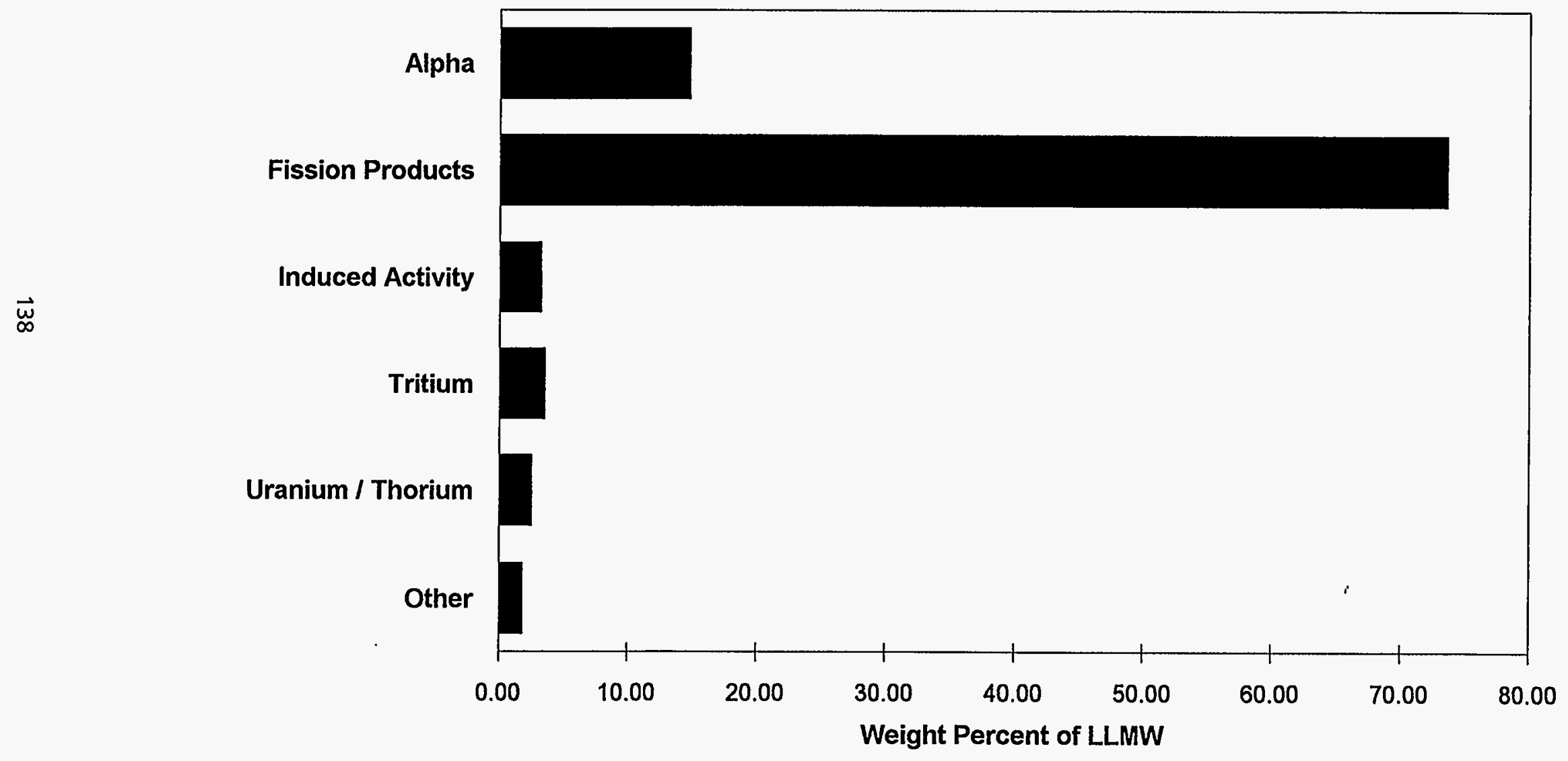

Information obtained from the DOE/RW-0006-Rev.8, October 1992 and EPA 520/1-91-010-2, May 1991. 


\section{Figure 3.103. Physical Matrix Distribution for Weldon Spring Site Derived for the ITTS Study*}

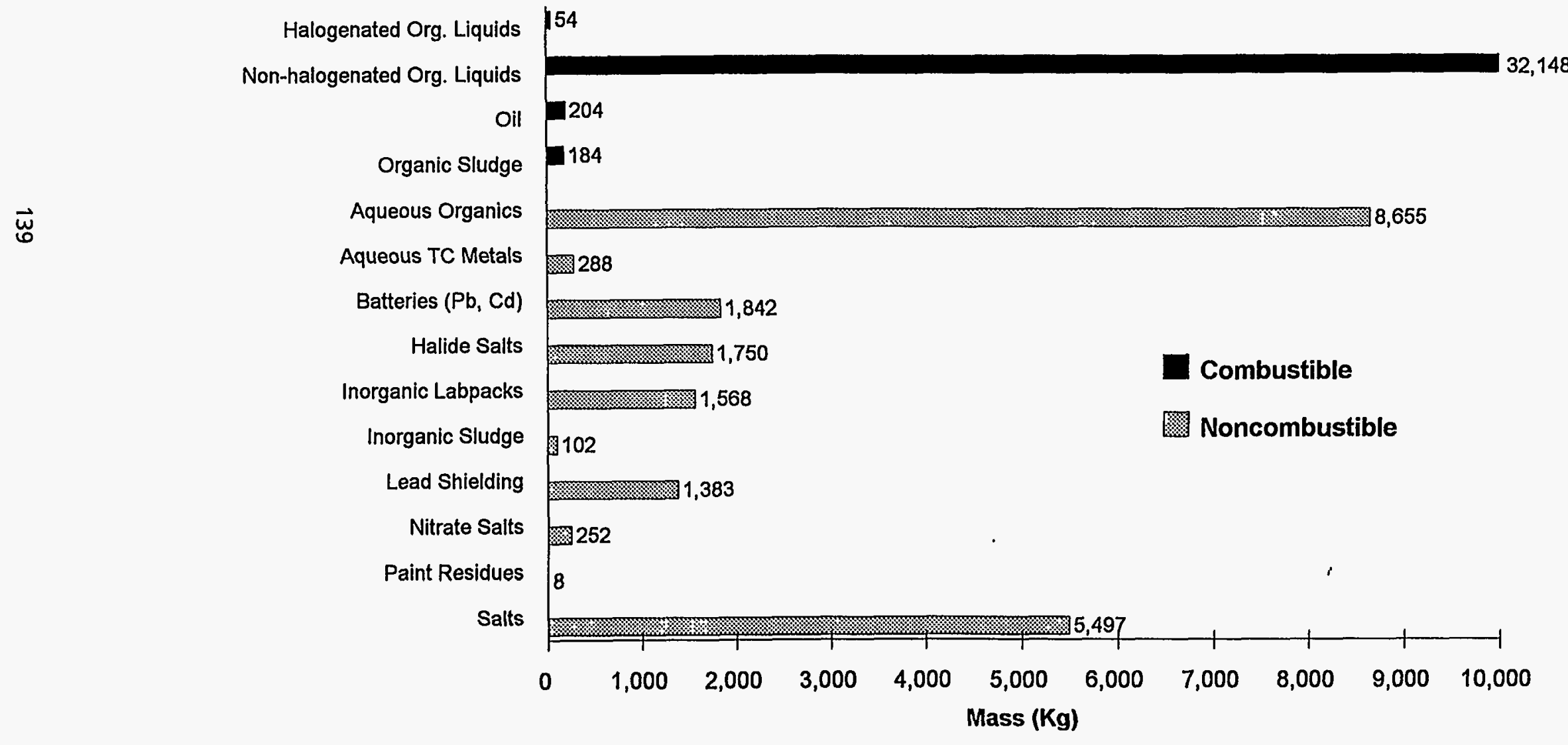

* Does not include mass due to containers.

Information obtained from the DOE/NBM-1100 (MWIR Report), April 1993. 


\section{Figure 3.104. Combustible vs. Noncombustible for Weldon Springs Site Derived for the ITTS Study (TOTAL $=53,936 \mathrm{Kg})^{*}$}

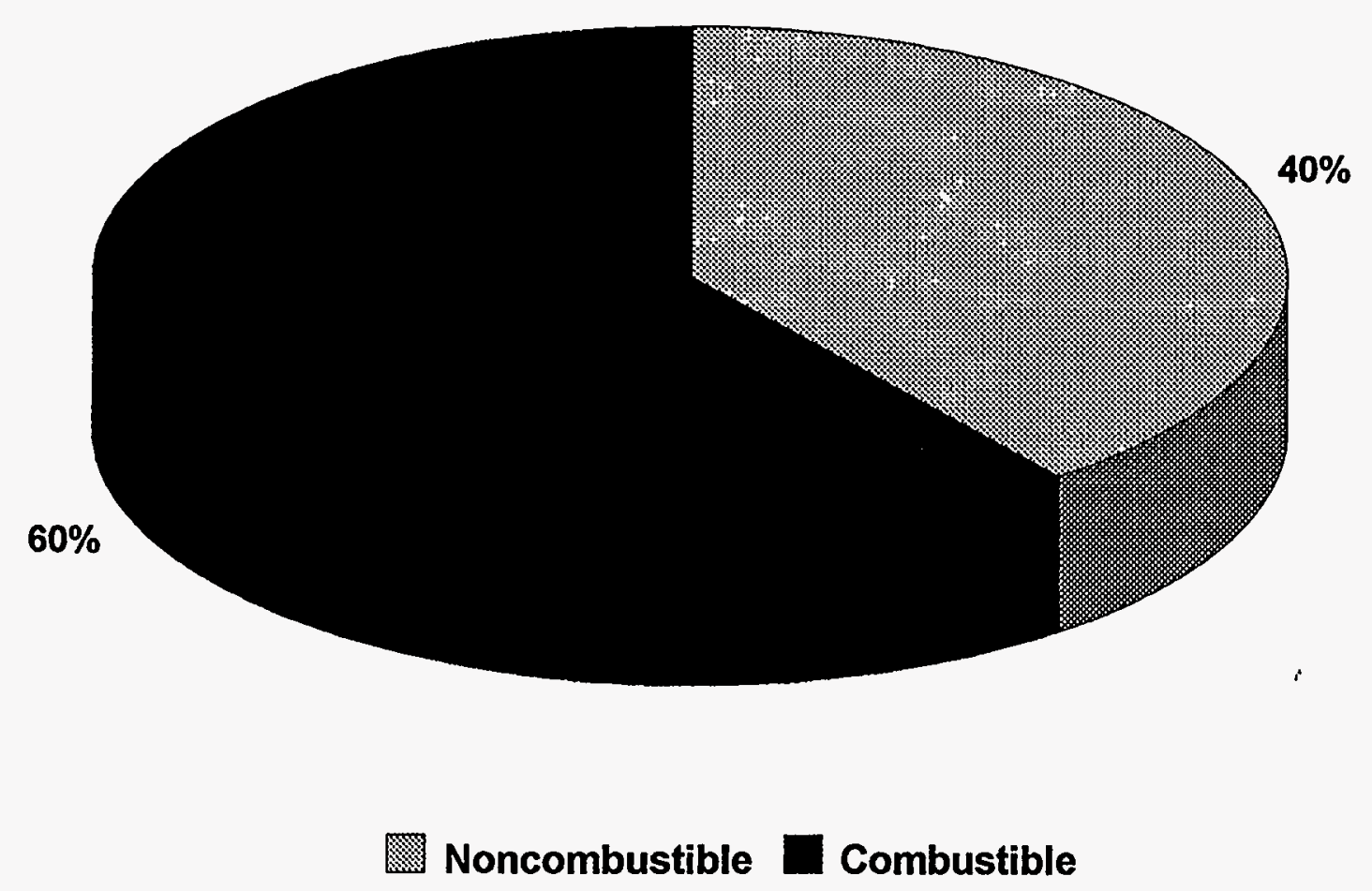




\section{Figure 3.105. Combustible Physical Matrix Distribution for Weldon Spring Site Derived for the ITTS Study (Combustibles $=32,590 \mathrm{Kg}$ )}

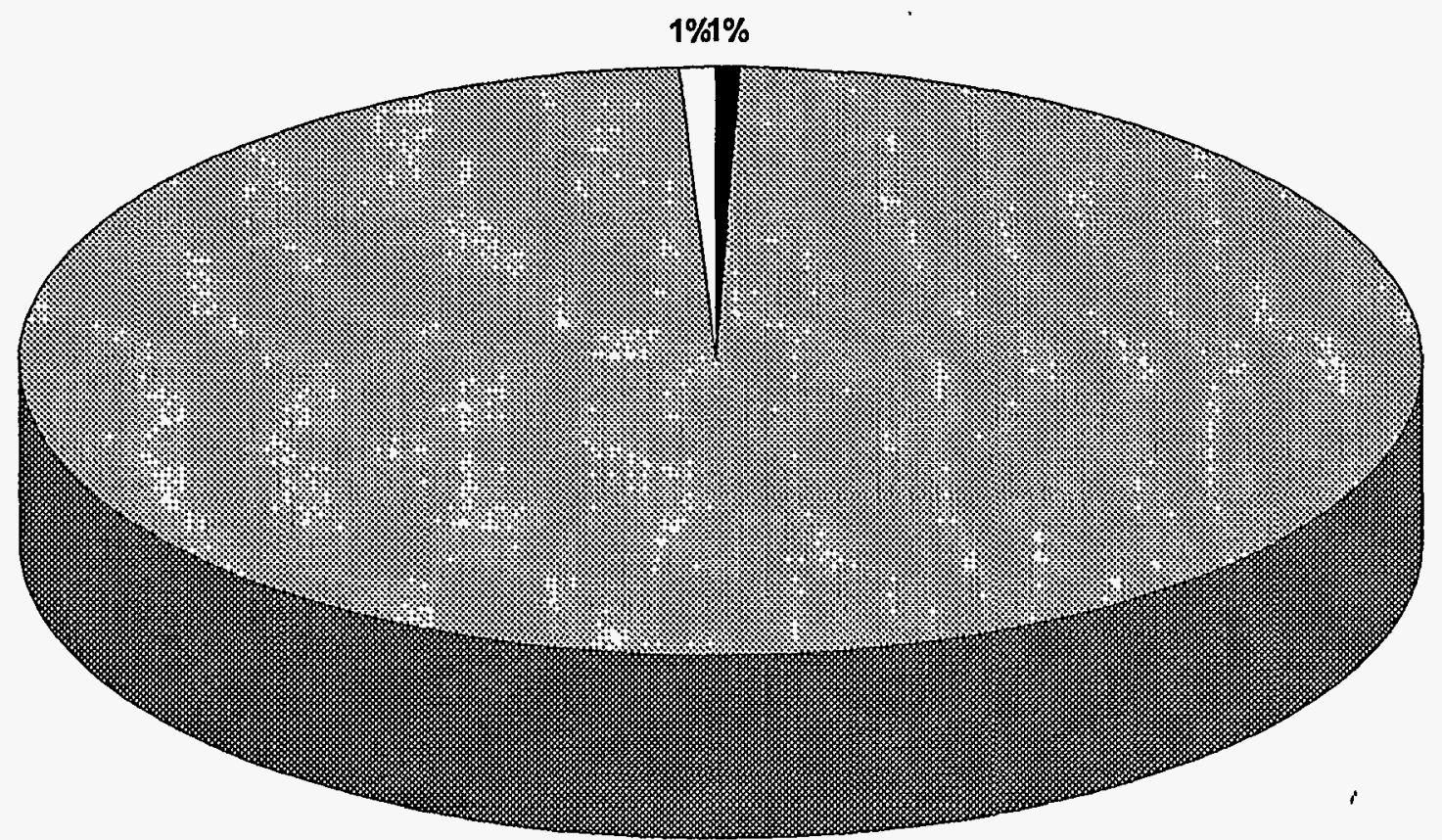

$98 \%$ 


\section{Figure 3.106. Noncombustible Physical Matrix Distribution for Weldon Spring Site Derived for the ITTS Study (Noncombustibles $=21,345 \mathrm{Kg}$ )}

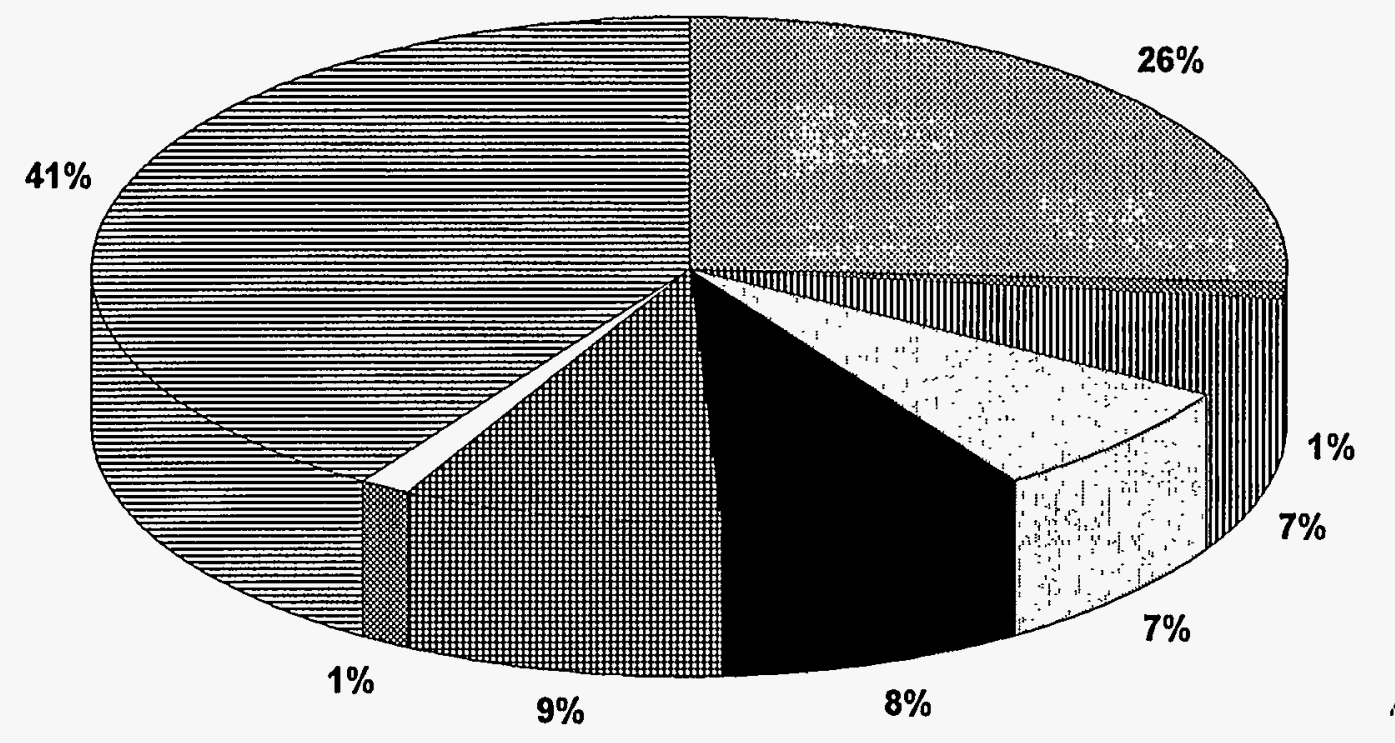
Salts
Nitrate Salts
[n] Lead Shielding
Inorganic Labpacks
Halide Salts
畊 Batteries (Pb, Cd)
$\square$ Aqueous TC Metals
目 Aqueous Organics 


\section{Figure 3.107. Radiological Distribution for Weldon Spring Site Derived for the ITTS Study}

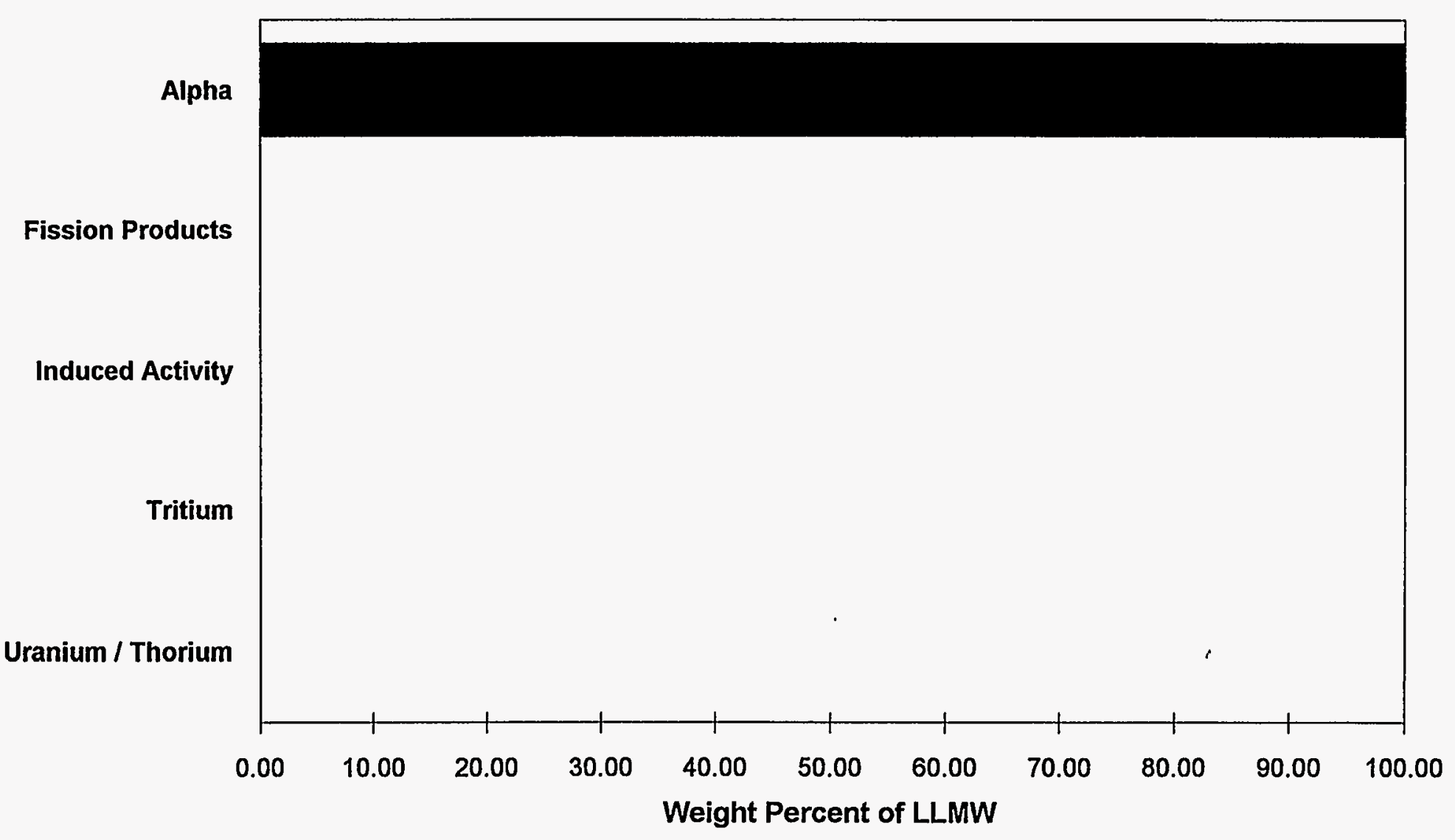

